ІНСТИТУТУ ІСТОРІЇ УКРАЇНИ НАН УКРАЇНИ ОДЕСЬКИЙ НАЦІОНАЛЬНИЙ УНІВЕРСИТЕТ імеНі І. І. МЕЧНИКОВА

ФАКУЛЬТЕТ ІСТОРІЇ ТА ФІЛОСОФІЇ

НАУКОВО-ДОСЛІДНИЙ ІНСТИТУТ КОЗАЦТВА

ВІДДІЛ ІСТОРІЇ КОЗАЦТВА НА ПІВДНІ УКРАЇНИ

INSTITUTE OF HISTORY OF UKRAINE

NATIONAL ACADEMY OF SCIENCES OF UKRAINE

ODESSA I. I. MECHNIKOV NATIONAL UNIVERSITY

THE DEPARTMENT OF HISTORY AND PHILOSOPHY

RESEARCH INSTITUTE OF COSSACKS

THE DEPARTMENT OF COSSACK HISTORY IN THE SOUTH OF UKRAINE

\author{
ЧОРНОМОРСЬКА МИНУВШИНА \\ CHORNOMORS'KA MYNUVSHYNA
}

Записки Відділу історії козацтва на Півдні України

The transactions of Department of Cossack History in the South of Ukraine

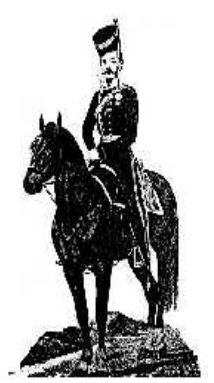

Випуск 15

Volume 15

Одеса - 2020

Odessa - 2020 


\section{ББК 63.3(4УК) \\ प 494 \\ УДК 94(477)}

Редакційна колегія:

академік НАН України, д.і.н. Смолій В.А. (почесний голова редколегії),

д.і.н. Бачинська О.А. (головний редактор), д.і.н. Гончарук Т.Г. (відповідальний секретар), д.і.н. Гуржій О.І., д.і.н. Діанова Н.М., д.і.н. Дзиговський О.М., д.і.н. Кіосак Д.В., д.і.н. Ковалевська О.О., д.і.н. Котляр Ю.В., д.і.н. Кульчицький С.В., д.і.н. Мільчев В.І., д.і.н. Михайлуца М.І., д.і.н. Музичко О.С., к.і.н. Новікова Л.В. (редактор англійського тексту), к.і.н. Полторак В.М., к.і.н. Середа О.Г., д.і.н. Черкас Б. В., д.і.н. Чухліб Т.В. (заступник головного редактора), д.і.н. Емеджен Ферідун (Туреччина), д.і.н. Киримли Хакан (Туреччина), д.і.н. Струква Грегор (Польща), д.і.н. Шакул Кахраман (Туреччина), к.і.н. Юнвер Метін (Туреччина), к.і.н. Яша Фират (Туреччина).

Затверджено до друку Вченою радою

Інституту історії України НАН України

(протокол № 8 від 24 грудня 2020 р.)

Ч 494 Чорноморська минувшина: Записки Відділу історії козацтва на Півдні України; за. ред. В.А. Смолія. - Одеса : ФОП Бондаренко М.О., 2020. - Випуск 15. $163 \mathrm{c}$.

ISSN 2519-2523

Свідоцтво Міністерства юстиції України про держсавну реєстрацію друкованого засобу масової інформації КВ №17749-6599P від 04. 05. 2011

Наказом МОН України від 24 вересня 2020 р. «Чорноморську минувшину» включено до Переліку фахових видань України, категорії “Б” (історичні спеціальності - 032)

Сайт та сторінки видання в Інтернет-просторі: http://chm.onu.edu.ua/; http://resource.history.org.ua/cgi-bin/eiu/history.exe; http://lib.onu.edu.ua/ua/chernomorskoe-proshloe/

Журнал реферується та індексується в наступних базах даних: Архів-репозитарій ОНУ імені I. І. Мечникова; Електронна бібліотека Інституту історіїУкраїни НАН України; «Наукова періодика України» НБ України імені В. І. Вернадського; Україніка наукова; Index Copernicus Journals Master List; Google Академія; Base-search

Висловлюємо щииу подяку за сприяння у виданні старшині та козакам Чорноморського Гайдамацького 3'єднання Украйнського козацтвва

Обкладинка: Козацький загін у поході (Альбом “3 української старовини” М. Самокиша, С.Васильківського). 
CTATTI

ISSN 2519-2523 (print)

Chornomors 'ka mynuvshyna. - 2020. - No.15

DOI: $10.18524 / 2519-2523.2020 .15 .218672$

УДК 94(477) “1699”

\title{
THE RETURN OF KAMIANETS-PODILSKYI UNDER THE POLISH POWER IN 1699: REACTIONS IN THE CRIMEAN KHANATE AND TURKEY
}

\author{
Stanislavskyj Vyacheslav \\ ORCID: https://orcid.org/0000-0003-4688-5978 \\ PHD (History), Senior Research Fellow \\ Institute of History of Ukraine of NAS of Ukraine \\ 4, Mykhailo Hrushevskyi str., Kyiv, 01001, Ukraine \\ vvslavaua@ukr.net
}

In 1699, under the terms of the Polish-Turkish Treaty of Karlowitz, the heavily fortified city of Kamianets-Podilskyi returned to the rule of the Polish-Lithuanian Commonwealth after 27 years of Turkish supremacy. In general, under the terms of treaties with Austria, Venice, Poland and Russia, the Ottoman Empire lost quite large areas. This defeat led to an increase in negative public sentiments in the empire towards the central government. Documents show that the loss of Kamianets was mentioned during a number of high-profile political events that took place in the Crimean Khanate and in Turkey in the early 18th century. The most important reason for such attention to this city was that it was given to the former enemy by agreement, and not as a result of armed struggle. To reduce negative public sentiments, the imperial authorities took various measures. It is known that for this purpose the former garrison of Kamianets-Podilskyi was located in several border fortresses of the empire. Warriors from this garrison were not transferred to the territory of Turkey. The imperial authorities also tried to shift the blame for the loss of the city on the Walachia ruler. However, this attempt was unsuccessful. For the Tatars, who were very active, the loss of Kamianets was important for several reasons. Firstly, the city ceased to serve as a fortified strong point for them in raids on areas that were under the rule of the Polish-Lithuanian Commonwealth. Secondly, they perceived very painfully the appearance of new fortified points near the borders of the Crimean Khanate, because they feared the invasion of enemy troops. Thirdly, the Treaties of Karlowitz forced them to change their traditional way of life, because they forbade to carry out plundering raids. Such circumstances led to the emergence of revanchist ideas in the Crimea, which also existed in Turkey. In 1702, Grand Vizier Daltaban Mustafa Pasha, in agreement with the Crimean Khan, planned a military campaign against the Russian state. The Vizier wanted to restore power to the Ottoman Empire in positions that had been lost during the war. At that time, he announced his intention to capture Kamianets-Podilskyi. After the failure of this plan, the Tatar uprising began in Budzhak, led by the Kalga-sultan Saadet-Girey. The author of this article was able to find a document that shows that the Kalga-sultan accused some representatives of the Ottoman Empire of losing Kamianets. One of the main accusations leveled at the time against the Turkish Sultan Mustafa II was also the accusation of losing the city. As a result of the incident in Edirne, Mustafa II lost his power.

Key words: Kamianets-Podilskyi, Treaties of Karlowitz, Polish-Lithuanian Commonwealth, Turkey, Crimean Khanate, Grand vizier Daltaban Mustafa Pasha, Kalga-sultan Saadet Girey, Incident in Edirne. 
В'ячеслав Станіславський
ORCID: https://orcid.org/0000-0003-4688-5978
Кандидат історичних наук,
старший науковий співробітник
Інститут історії України НАН України
Вул. Грушевського, 4, Київ, 01001, Україна
vvslavaua@ukr.net

\section{ПОВЕРНЕННЯ КАМ'ЯНЦЯ-ПОДІЛЬСЬКОГО ПІД ПОЛЬСЬКУ ВЛАДУ В 1699 р.: РЕАКЦІЇ В КРИМСЬКОМУ ХАНАТІ ТА ТУРЕЧЧИНІ}

В 1699 р. за умовами польсько-турецького Карловицького договору під владу Речі Посполитої, після 27 років турецької зверхності, повернулося потужне місто-фортеця Кам'янець-Подільський. Загалом, за умовами договорів з Австрією, Венецією, Польщею та Росією Османська імперія втратила досить значні територіі. Ця поразка зумовила зростання негативних настроїв в імперії стосовно иентральної влади. Документи свідчать, що про втрату Кам'янця згадували під час низки резонансних політичних подій, які відбувалися в Кримському ханстві та в Туреччині на початку XVIII cm. Найважливішою причиною такої уваги саме до изього міста стало те, що воно було віддане колишньому противнику за домовленістю, а не в результаті збройної боротьби. Для зниження негативних суспільних настроїв влада імперії вживала різних заходів. Відомо, щяо з иією метою колишній гарнізон Кам'яния-Подільського був розташований у кількох прикордонних фортеиях імперії. На територію Туреччини вояків з иьього гарнізону не переводили. Також влада імперії зробила спробу перекласти вину за втрату міста на волоського правителя. Однак ия спроба була невдалою. Для татар, які виявляли значну активність, втрата Кам'яния мала велике значення з кількох причин. По-перше, місто перестало слугувати для них укріпленим опорним пунктом при здійсненні набігів на терени, які знаходилися під владою Речі Посполитої. По-друге, вони дуже болісно сприймали появу нових укріплених пунктів поблизу кордонів Кримського ханату, оскільки боялися вторгнення ворожих військ. По-третє, Карловицькі договори змушували їх змінити традиційний спосіб життя, оскільки забороняли здійснювати грабіжницькі набіги. Такі обставини призвели до виникнення в Криму реваншистських ідей, які існували також в Туреччині. В 1702 . великий візир Далтабан Мустафа-паша, домовившись з кримським ханом, планував похід проти Російської держави. Візир хотів відновити владу Османської імперії на позиціях, які були втрачені під час війни. В той час він заявляв про намір захопити Кам'янець-Подільський. Після провалу цього плану почалося татарське повстання в Буджаку, яке очолив калгасултан Саадет-Гірей. Вдалося з'ясувати, щзо калга-султан звинувачував окремих представників влади Османської імперії у втраті Кам'яния. Одним із головних обвинувачень, які висувалися в той час туречькому султану Мустафі II також було звинувачення у втраті цього міста. В результаті інциденту в Едірне Мустафа ІІ втратив свою владу.

Ключові слова: Кам'янець-Подільський, Карловичькі угоди, Річ Посполита, Туреччина, Кримський ханат, великий візир Далтабан Мустафа-паша, калга-султан Саадет-Гірей, іниидент в Едірне.

Укладення Стамбулом Карловицьких угод зі своїми противниками - Віднем, Венецією, Варшавою та Москвою принесло Турецькій державі великі територіальні втрати. А це, звісно, засвідчувало іiї слабкість та зумовлювало негативні реакції в різних частинах імперії та різних суспільних верствах. Подекуди в історичній літературі та джерелах зустрічаються згадки про такі реакції в Кримському ханаті та Туреччині у зв'язку з втратою Кам'янця-Подільського, який був захоплений турками в 1672 р., а залишений ними в 1699 р., коли повернувся під владу Речі Посполитої. А 
фіксувалися ці згадки насамперед тому, що були пов'язані з певними резонансними політичними подіями чи явищами значного масштабу.

Відомо, що Карловицькі угоди не лише поставили Крим в обставини, коли мали припинитися вигідні для значного числа його мешканців набіги на терени сусідніх країн, а й змусили відчути небезпеку ворожого вторгнення. Османський вчений кримського походження XVIII ст. Сеїд Мухаммед Риза влучно та красномовно висловився, написавши, що від часу Карловицьких угод “мешканці Криму стали позирати через двері страху та чекання на події часу” $[12$, с. 473 ; про походження вченого див.: 12, с. 31-33; 11, с. 35-41].

В цьому ж контексті вельми негативно мали сприйняти татари й втрату Кам'янця-Подільського 3 якого вони отримували ще й значну користь в часи турецького володіння містом - він був для них базою для більш далеких виправ та притулком при невдачах таких нападів [2, s. 217]. Поголоски про татарські реакції на новину про передачу Польщі Кам'янця доходили вже до самих учасників Карловицького конгресу. Наприкінці жовтня 1698 р. думний радник Прокофій Возніцин, який був представником Росії на Карловицьких переговорах, відправив до свого уряду листа, в якому зазначалось: "Ще від багатьох заноситься, також і 3 польських висловлювань зрозуміло, що турки за Кам’янець стояти не будуть, оскільки є їм великим тягарем, а користі ані найменшої немає - тільки хан для прихистку татарських набігів віддавати його не присуджує" [7, с. 241]. А на початку березня 1699 р. надійшла новина про татарський набіг. Тоді П. Возніцин писав у Москву: “При цісарському дворі пронеслося, що татари великим зібранням, впавши в Польщу, зі злоби своєї, що турки полякам Кам'янець віддати обіцяли, не милостиво, не беручи нікого в полон, рубали, через те, якщо б їм брати в полон, то б примушені були турками знову повернути; і через те велике кровопролиття та розорення вчинили" [7, с. 550].

Негативні настрої були значними і у верхівці Османської імперії, про що навіть писала європейська преса. В 1699 p. "Gazette de France" повідомляла про значне незадоволення багатьох вищих турецьких урядовців 3 приводу рішення про реституцію Кам'янця зокрема та умовами Карловицьких угод загалом через великі територіальні втрати для Османської імперії. При цьому газета нагадала відомий турецький принцип, який забороняв добровільно віддавати захоплені терени [3, s. 63-64].

С дані, які призводять до висновку про існування дуже різного бачення виходу 3 тодішньої політичної ситуації у керівництві імперії, чому робилися й різноспрямовані заходи. Певні кроки показують намагання поступово пригасити негативні настрої. Так, вояків колишньої турецької залоги Кам'янця-Подільського після виходу з міста було заборонено переводити на територію власне Туреччини, що на думку одного 3 дослідників засвідчує прагнення Стамбула притупити враження від територіальних поступок, які вона зробила на користь своїх противників і які були закріплені Карловицькими угодами 1699 р. Натомість залога була розділена на частини, які розташували в прикордонних фортецях імперії - Кілбуруні, Аккермані, Яник-Хісарі, Очакові, Кілії, Бендерах і Бабадазі [1, р. 22].

Але поряд зі спробами примирити суспільні настрої з масштабними втратами певні представники найвищої влади Османської імперії плекали реваншистські настрої. Одним 3 найяскравіших проявів таких тенденцій стала спроба великого візира за згодою 3 кримським ханом нанести удари по Російській державі, за допомогою яких загроза з боку Москви була би усунута, чи, принаймні, значно зменшена. Особливу активність в цій справі виявили татари, які погрожували самій 
Туреччині, якщо та їм не допоможе. Отже, восени 1702 р., $з$ призначенням великим візиром Далтабана Мустафи-паші, кримський хан Девлет Гірей II отримав підтримку своїм планам війни 3 Російською державою. Він знайшов певне сприяння і на Запорозькій Січі, а в грудні відправив війська в Буджак на чолі з братом - калгоюсултаном Сеадет-Гіреєм, де той гуртував сили для походу проти Росії. Татари говорили, що при відмові османської влади від надання підтримки, вони, разом 3 Девлет-Гіреєм II, перейдуть Дунай і підуть плюндрувати Румелію аж до Стамбула. Однак султан Мустафа II був проти конфлікту з Москвою і наприкінці грудня змістив Девлет-Гірея II, а новим ханом призначив його батька Селім-Гірея I, який обіцяв дотримуватися миру 3 росіянами. Ця відставка призвела до повстання, турецькі залоги в Ізмаїлі, Кілії та Очакові потрапили в облогу, татарські сили вирушили до Дуная, але перейти його не змогли, бо того року річка не замерзла. Тим часом надійшли, направлені проти повсталих, турецькі війська. В січні 1703 р. був зміщений 3 посади і страчений великий візир. Повстання було приречене на поразку [12, с. $483-$ $489 ; 10$, с. $277-278]$.

В контексті теми, яка розглядається, важливо, що, плануючи війну з Москвою, великий візир Далтабан Мустафа-паша заявляв про взяття Кам'янця-Подільського як своє першочергове завдання, хоча місто на той час перебувало під польською, а не під російською владою. Так, він писав кримському хану й татарським емірам: “Я відкриваю похід на московів. Зібравшись у Бендерах, після того як візьмемо в ляхів фортецю Каманчу, піду в країну московів. А ви теж, спорядившись, рухайтесь” [12, c. 483].

Невідомо, чи події розвивалися би за цим сценарієм, але важко уявити, щоб візир наважився піти на конфлікт одразу з двома противниками, а тим більше, щоб він зумів отримати значні успіхи в протистоянні 3 обома під час одного походу. Повторне взяття Кам'янця-Подільського було б значним успіхом у протистоянні 3 Річчю Посполитою, після чого треба було б надто багато сил і часу, щоб здійснити ще й успішну виправу на терени, підвладні царю. Відомо ж бо, що Далтабан Мустафапаша планував також ударити разом з татарами на Азов і Київ [6, с. 52-53].

В тому, що втрата Кам'янця-Подільського була подією, котра була надто прикрою для татар переконує віднайдений у Російському державному архіві давніх актів документ, який включає згадку про місто однією 3 найвищих посадових осіб Кримського ханату, коли там відбулося згадане повстання. Отже, 2 січня 1703 р. від єрусалимського патріарха Досифея II до російського посла були переслані відомості, надіслані мультянським боярином, котрий перебував при сераскері Юсуф-паші в м. Сакча в якості резидента, до свого господаря Костянтина Бринковяну, а вже від господаря передані патріарху. У них привертає увагу радикальне висловлювання калги-султана, який реагував на слова Бесил-аги з Ізмаїла про приїзд до Адріанополя свого батька - “старого хана”, звинувачував Юсуф-пашу, муфтія та реіс-ефенді в передачі противникам Кам'янця, а свого батька - в уступці Азова. Цих людей він назвав гяурами - невірними, заявив про готовність збройного протистояння зі своїм батьком: “якщо сюди прийде буду битися, і наповню все його серце стрілами”, а також бажав розправи над названими представниками верхівки імперії. В разі виконання османським урядом цих - “якщо нам видасть Порта три голови” - та інших вимог обіцяв втихомирення, а інакше погрожував війною: “а якщо нас не послухає, будем воювати, аж поки всі пропадемо, і як замерзне Дунай, підемо скачучи i розбиваючи до Балкана" [9, л. 1 об.-2]. Представника валашського господаря при Юсуф-паші єрусалимський патріарх ідентифікував як капи-кегаю господаря [9, л. 13]. 
Дана заява є свідченням вкрай негативної реакції представника верхівки Кримського ханату на втрати Османською імперією значних теренів в результаті війн 3 коаліцією ворожих держав. Що ж до негативного відгуку калги-султана про представників турецької влади, то він виглядає надто радикальним, що, вочевидь, визначалося тодішнім політичним становищем калги, який був на чолі бунтівної частини підлеглого Туреччині ханату. Та й, певно, така риторика була до вподоби його послідовникам.

Того року про Кам'янець говорили в Туреччині з приводу іще однієї кризи, яку називають чи то інцидентом в Едірне, чи то Адріанопольським інцидентом. Йшлося про внутрішню кризу, яка була спричинена потрясіннями, що відбувалися в Османській імперії починаючи 31683 р. В результаті повстання, яке розпочали капикулу, був скинутий султан Мустафа II і вбитий шейхульіслам (великий муфтій) Фейзуллах-ефенді [14, с. 45; див. також: 5, с. 236-244].

Ось як описав ситуацію в імперії, ставлення турецького суспільства до нових реалій, які були закріплені Карловицькими угодами відомий дослідник В. Смірнов: “... усунення 3 посади і потім страта верховного візира Дал-Табан-Мухаммед-паші були скільки результатом інтриги проти нього шейху-ль-ісляма, стільки ж і справою політичних міркувань, за якими занадто войовничий дух садразама і просякнута цим духом його політика були визнані не відповідними вимогам того часу. Але турецьке суспільство не скоро змогло змиритися з цими необхідними обмеженнями його одвічної зарозумілості. Яничари залишилися невдоволені заміною войовничого візира i призначенням на його місце людини переважно цивільної, хоча й прекрасного стиліста Рамі-паші: під першим-ліпшим приводом вони підняли бунт, який коштував султану Мустафі II (1695-1703) трону” [13, с. 10-11].

Вочевидь, напередодні інциденту в Едірне знову робилися кроки заради заспокоєння суспільних настроїв. Наприкінці серпня 1703 р. посланець валашського господаря Федір Корбя розповідав у похідній Посольській канцелярії про невдалу спробу турецьких урядовців зменшити негативне ставлення свого народу до факту передачі полякам Кам'янця-Подільського: що “без крові ту фортецю віддали”. 3 цією метою “мали вони, турки, давно намір і радилися між собою”, замислюючи змістити 3 посади волоського господаря, посадити на його місце свого пашу і оголосити, що були вимушені віддати Кам'янець після того як невірний їм господар віддав полякам Сороки, що, своєю чергою, унеможливило підтримку і постачання подільського міста. Реалізації ж такого наміру перешкодив супротив молдован i валахів, які схилили на свій бік і кримського хана [4, с. 196]. 12 липня того року Ф. Корбя приїхав 3 Адріанополя [4, с. 196], де тоді перебував султан, в Бухарест, а тому його свідчення показують настрої, які існували в Туреччині незадовго до повстання. Також посланець розповів про новину з Туреччини від брата господаря про бунт проти візира та муфтія, до якого підбурювали яничар духовні особи. I в цьому випадку причиною була уступка подільської твердині без збройної боротьби: бунтівники хотіли змінити візира та муфтія “за віддачу без крові Кам’янця” [4, с. 197].

Залишення турецькими військами Кам'янця при реалізації Карловицького договору з Польщею було одним із головних звинувачень, які висувалися тоді самому султану Мустафі II [1, p. 36]. Д. Колодзейчик доводить, що це питання було аргументом в боротьбі за владу в Туреччині насамперед тому, що Кам'янець був не захоплений противником, а відданим йому без бою, в той час як імперія й так втратила великі території [2, s. 221]. До того ж у верхівці державі було багато невдоволених й тим, що, помирившись 3 християнськими государями, султан 
порушив “магометанський закон”, “котрий наказує султанам і туркам завжди мати війну” [6, с. 50].

Серед матеріалів російського посольства в Туреччині трапився також документ, який дає змогу ідентифікувати двох турецьких урядовців, котрі раніше перебували на службі у Кам'янці-Подільському, а пізніше виконували завдання по спостереженню за російською активністю на кордоні з Османською імперією. Отже, в 1702 р. єрусалимський патріарх переслав до П. Толстого новини від валашського господаря. Представник господаря при сераскері Юсуф-паші дізнався, що сераскер посилав двох своїх людей - Сери Мехмет-агу та Солкол Мустафу-агу, а колишніх урядовців Кам'янця-Подільського - “котрі в Кам'янці бували начальниками”, “до черкасів” на огляд міста, яке споруджувалося на території Запорожжя. I це завдання було ними виконане [8, л. 390 об., 394 об.-395].

Зазначені згадки про Кам'янець-Подільський прямо засвідчують велике значення, якого надавали і в Кримському ханаті, і в Туреччині передачі цього міста під владу Речі Посполитої. I чи не найбільшим подразником була його втрата без бою, в результаті мирної угоди, що, вочевидь, мало розцінюватися як зрада інтересів держави. А тому влада Османської імперія вживала заходів, що зменшити негативне враження в суспільстві від втрати міста, тому про Кам'янець-Подільський говорили і під час підготовки великим візиром і кримським ханом походу на Російську державу, і під час повстання в Криму, і під час повстання в Османській імперії, яка призвела до зміни на султанському троні.

\section{Джерела та література:}

1. Abou-El-Haj Rifa'at Ali. The 1703 rebellion and the structure of Ottoman politics. / Abou-El-Haj Rifa'at Ali. - Leiden: Nederlands Historisch-Archaeologisch Instituut te Istanbul, 1984. - 124 p.

2. Kołodziejczyk D. Podole pod panowaniem tureckim. Ejalet Kamieniecki 1672-1699. / D. Kołodziejczyk. - Warszawa: Oficyna wydawnicza POLCZEK Polskiego Czerwonego Krzyża, 1994. - 255 s. 3. Ujma M. Traktaty karłowickie w świetle relacji "Gazette de France" z 1699 r / M. Ujma // Balcanica Posnaniensia. Acta et studia. - T. XIII. - Poznań: Adam Mickiewicz University Press, 2003. - S. 59-77.

4. Исторические связи народов СССР и Румынии в XV - начале XVIII в.: документы и материалы в трех томах. Т. 3: 1673-1711 / Сост.: В. А. Костакэл, Е. М. Руссев, Л. Е. Семенова. - Москва: Наука, 1970. $-416 \mathrm{c}$.

5. Орешкова С. Ф. Государственный переворот 1703 г. в Османской империи (по материалам российских архивов) / С.Ф. Орешкова // Российское востоковедение в память о М. С. Капице. Очерки, исследования, разработки. - Москва: Муравей, 2001. - С. 236-244.

6. Орешкова С. Ф. Русско-турецкие отношения в начале XVIII в. / С. Ф. Орешкова. - Москва: Наука, 1971. - 206 с.

7. Памятники дипломатических сношений древней России с державами иностранными. - Т. 9: Памятники дипломатических сношений с Римскою империею (с 1698 по 1699 год). - СПб., 1868.

8. Российский государственный архив древних актов. - Ф. 89. - Оп. 1. - 1702. - Д. 1.

9. Российский государственный архив древних актов. - Ф. 89. - Оп. 1. - 1703. - Д. 3.

10. Санин О. Г. Антисултанская борьба в Крыму в начале XVIII в. и ее влияние на русскокрымские отношения / О. Г. Санин // Материалы по археологии, истории и этнографии Таврии. -Вып. 3. - Симферополь: Таврия, 1993. - С. 275-279.

11. Сейтягьяев Н. С. Происхождение Сейида Мухаммеда Ризы (к вопросу о месте его "Семи планет" среди произведений крымской исторической прозы XVIII века) / Н. С. Сейтягьяев // Культура народов Причерноморья. - 2003. - № 44. - С. 35-41.

12. Смирнов В.Д. Крымское ханство под верховенством Оттоманской Порты до начала XVIII века. / В. Д. Смирнов - Москва: Издательский дом “Рубежи XXI”, 2005. - 542 с. 
14. Смирнов В. Д. Крымское ханство под верховенством Отоманской Порты в XVIII в. до присоединения его к России. / В. Д. Смирнов - Москва: Издательский дом “Рубежи XXI", 2005. $314 \mathrm{c}$.

15. Эмеджен Ф. От создания Османского государства до Кючук-Кайнарджийского договора / Ф. Эмеджен // История Османского государства, общества и цивилизации. - Т. 1. - Москва: Издательская фирма “Восточная литература" РАН, 2006. - С. 3-50.

\section{References:}

1. Abou-El-Haj Rifa'at Ali, 1984. The 1703 rebellion and the structure of Ottoman politics. Leiden: Nederlands Historisch-Archaeologisch Instituut te Istanbul. [In English].

2. Kołodziejczyk, D., 1994. Podole pod panowaniem tureckim. Ejalet Kamieniecki 1672-1699. Warszawa: Oficyna wydawnicza POLCZEK Polskiego Czerwonego Krzyża. [In Polish].

3. Ujma, M., 2003. Traktaty karłowickie w świetle relacji "Gazette de France" z 1699 r. Balcanica Posnaniensia. Acta et studia, XIII, p. 59-77. [In Polish].

4. Kostake'l, V. A., Russev, E. M. \& Semenova, L. E. comps., 1970. Istoricheskie svyazi narodov SSSR $i$ Rumynii v XV-nachale XVIII v.: dokumenty i materialy v trex tomax. Vol. 3: 1673-1711. Moskva: Nauka. [in Russian].

5. Oreshkova, S. F., 2001. Gosudarstvennyj perevorot 1703 g. v Osmanskoj imperii (po materialam rossijskix arxivov). Rossijskoe vostokovedenie v pamyat' o M. S. Kapice. Ocherki, issledovaniya, razrabotki, Moskva: Muravej, 236-244. [in Russian].

6. Oreshkova, S. F., 1971. Russko-tureckie otnosheniya v nachale XVIII v. Moskva: Nauka. [in Russian].

7. Pamyatniki diplomaticheskix snoshenij drevnej Rossii s derzhavami inostrannymi, 1868. Vol.9: Pamyatniki diplomaticheskix snoshenij s Rimskoyu imperieyu (s 1698 po 1699 god). Sankt-Peterburg. [in Russian].

8. Sanin, O. G., 1993. Antisultanskaya bor'ba v Krymu v nachale XVIII v. i ee vliyanie na russkokrymskie otnosheniya. Materialy po arxeologii, istorii i e'tnografii Tavrii, 3, 275-279. [in Russian]. 9. Sejtyag'yaev, N. S., 2003. Proisxozhdenie Sejida Muxammeda Rizy (k voprosu o meste ego "Semi planet" sredi proizvedenij krymskoj istoricheskoj prozy XVIII veka). Kul'tura narodov Prichernomor'ya, 44, 35-41. [in Russian].

10. Smirnov, V. D., 2005. Krymskoe xanstvo pod verxovenstvom Ottomanskoj Porty do nachala XVIII veka. Moskva: Izdatel'skij dom "Rubezhi XXI". [in Russian].

11. Smirnov, V. D., 2005. Krymskoe xanstvo pod verxovenstvom Otomanskoj Porty v XVIII v. do prisoedineniya ego $k$ Rossii. Moskva: Izdatel'skij dom "Rubezhi XXI". [in Russian].

12. E'medzhen, F., 2006. Ot sozdaniya Osmanskogo gosudarstva do Kyuchuk-Kajnardzhijskogo dogovora. In E'. Ixsanoglu ed., Istoriya Osmanskogo gosudarstva, obshhestva i civilizacii. Vol. 1. Moskva: Izdatel'skaya firma "Vostochnaya literatura" RAN, pp. 3-50. [in Russian].

Отримано: 29.11.2020 p. 
ISSN 2519-2523 (print)

Chornomors'ka mynuvshyna. - 2020. - No.15

DOI: $10.18524 / 2519-2523.2020 .15 .218673$

УДК 94(477)

\section{ADZHIDERE / HADZHIDERE: TO THE QUESTION ON THE OTTOMAN NAME OF THE VILLAGE OF OVIDIOPOL}

Oleksandr Sereda

ORSID: https://orcid.org/0000-0002-5921-8907

$\mathrm{PhD}$ (History), Associate Professor

South Ukrainian National Pedagogical University

named after K. D. Ushynsky

26, Staroportofrankivs'ka St., Odessa, 65020, Ukraine

olexer@ukr.net

The purpose of this article is to study the use of the Ottoman name of the modern village of Ovidiopol from the first mention of the settlement to its final renaming by the Russian government (1756 - 1794). The examples show the designation of the settlement in Ottoman-Turkish sources and the transformation of the name when translated into other languages and in particular into Russian. One of the first known written mentions of the name of Adzhidere can be found in Ottoman-Turkish sources of the middle of the XVIII century. from the Government Ottoman Archives in Istanbul. In particular, the oldest designation of the settlement on the site of the modern village of Ovidiopol is in an extract from the port log / defter, which contains information on loading and dispatching merchant ships from Adzhidere Pier to Istanbul's harbor Kapan-i Dakik - the coastal quarter in Golden Horn Bay. The annotation to this document states that the port log / defter is the register of loading and dispatch of grain from the port of Adzhidere since the beginning of the month of Muharram in 1170 AH, which corresponds to the date from September 26, 1756. In the report of the Russian intelligence of 1758 Ovidiopol is already mentioned as Gadzhidere. In particular, it is reported about the purchase of wheat and rye by Turks, Crimean Tatars, Nogai, Greeks and Wallachians, and its transportation to "different cities such as Ochakov, Belgorod and Hadzhidere, Bender, Kiliya, Smailov (Izmail) and the Wallachian city Iasi" The next source, with the designation Adzhidere, are the Ottoman-Turkish documents of the Governmental Ottoman Archive in Istanbul from the collection "State Administration", dated 1765. The documents contain several different texts from public institutions and resolutions to be implemented. A number of sources of the next period of 1780-90s indicate the Ottoman name of modern Ovidiopol both Adzhidere and Hadzhidere. Thus, in the travel description of the French engineer Lafitte-Clave, who worked for the military department of the Ottoman Empire in 1784-87, "Hadzhi Dere" was mentioned. In the description of the Ochakov land made by the Russian engineer De Volan in 1791, it is said about Adzhidere after the Russo-Turkish wars. Such double names of settlements are sometimes found in Ottoman documents due to the ignorance of the Ottoman bureaucracy of toponyms of remote regions of the Ottoman state. Such a document is the Ottoman map of 1790, as evidenced by the content of inscriptions and explanations to the settlements. A new source has been put into scientific circulation - a cartographic image of the Dniester estuary with marked key settlements on its shores and defined areas of navigation through the estuary straits with the Black Sea.

Key words: Adzhidere, Ovidiopol, Dniester Estuary, Ottoman-Turkish sources, toponymy. 
Олександр Середа

ORSID: https://orcid.org/0000-0002-5921-8907

Кандидат історичних наук, доцент

Південноукраїнський національний педагогічний

університет імені К. Д. Ушинського

Вул. Старопортофранківська, 26, м. Одеса, 65020, Україна

olexer@ukr.net

\section{АДЖИДЕРЕ / ХАДЖИДЕРЕ: ДО ПИТАННЯ ОСМАНСЬКОЇ НАЗВИ СЕЛИЩА ОВІДІОПОЛЬ}

Метою иієї статті є дослідження використання османської назви сучасного селища Овідіополь від першої згадки населеного пункту до остаточного перейменування його російським урядом (1756 - 1794). На прикладах надано позначення населеного пункту в османсько-турецьких джерелах $i$ трансформація назви при перекладах на інші мови $i$ зокрема на російську. Введено у науковий обіг нового джерела - картографічного зображення Дністровського лиману з позначеними ключовими населеними пунктами на його берегах та визначеними сферами судноплавства протоками лиману з Чорним морем.

Ключові слова: Аджидере, Овідіополь, Дністровський лиман, османсько-турецькі джерела, топонімія.

Османське панування у Північно-Західному Причорномор'ї позначилось розбудовою здавна існуючих міст-фортець Аккерман, Кілія, Очаків, Бендер i Ходжабей. Окрім цього, залюднення степових просторів Очаківської землі на межі XVII - XVIII ст. спонукає до будівництва нових портів чи пристань для логістичного забезпечення темпів зростаючого зернового виробництва на причорноморських степах. У такому вирішенні питання османська влада навпроти Аккермана будує на лівому березі Дністровського лиману нову хлібну гавань, яка має за різними письмовими i картографічними джерелами назву Аджидере чи Хаджидере (у російській абревіатурі Гаджидере).

Визначаючи перешоджерела назви населеного пункту передусім потрібно звернути увагу на документи інформаційно-просторового поля османської бюрократії, в межах якого найбільше зустрічається османсько-турецьке позначення назви селища. Одними 3 перших відомих письмових позначень Аджидере є декілька османськотурецьких джерел середини XVIII ст. $з$ Урядового Османського Архіву у Стамбулі. Зокрема, найбільш давнім позначенням населеного пункту на місці сучасного селища Овідіополь $є$ виписка 3 портового журналу/дефтеру, в якому міститься інформація про завантаження i відправки торговельних суден 3 пристані Аджидере до стамбульської гавані Капан-и дакік [1] - прибережного кварталу в затоці Золотого Рогу Стамбула. В анотації до цього документа зазначено, що портовий журнал/дефтер $\epsilon$ регістром завантаження і відправлення збіжжя 3 пристані Аджидере 3 початку місяця мухаррем 1170 р. за хіджрою, що відповідає терміну з 26 вересня 1756 р. В самому дефтері відображено реєстраційні дати прибуття суден 3 вересня по листопад 1756 р., до часу замерзання прісноводного лиману Дністра.

Відповідно до записів дефтеру, для відправки до Стамбула двох основних продуктів - пшениці й ячменю, в Аджидере завантажено на 23 судна, з яких більшість мали фрахтування у стамбульській гавані Капан-и дакік та Аккермані, а решта з портів Варна, Трабзон та Уньє. Загальна кількість завантажень відправленого збіжжя у дефтері становила вагу 20773 аккерманських кілє, що відповідало 70850 стамбульським кілє 
(приблизно 1771,25 т. зерна). У документі також зазначено відвантаження у цей самий період 1756 р. з Аккермана - 57150 стамбульських кілє пшениці та ячменю, що на чверть менше від Аджидере. У той же час зазначається, що Аджидере знаходиться у судовоадміністративному окрузі “каза Аккерман” [8, с. 210-214].

Подальше зазначення Овідіополя саме за назвою Аджидере також відображено в наказі кримського хана, датованого груднем 1758 р., щодо постачання зернового збіжжя до Стамбула, де Аджидере фігурує як основний порт/пристань у якості пункту збору зернових з Очаківської землі загалом і зокрема з Ханської України [2; 5, с. 188]. Однак в донесенні російської розвідки цього ж 1758 р. Овідіополь зазначається вже як Гаджидере. Зокрема, повідомляється щодо закупівлі турками, кримськими татарами, ногайцями, греками і волохами пшениці і жита та його звезення до «міст різних як-то до Очакова, Білгорода й Гаджидери, до Бендер, Кілії, Смаілова (Ізмаїл) і до волоського міста Яси» [6, с. 64-65].

Наступним джерелом, 3 позначенням Аджидере є османсько-турецькі документи Урядового Османського Архіву у Стамбулі 3 колекції «Державна адміністрація», датовані 1765 р. Документи містять декілька різних текстів з інституцій державного управління і резолюцій до виконання. Всі тексти інформують про повідомлення голови адміністрації Ходжабею - Хафиз Ельхадж Мехмеда до Очаківського валії/губернатора, Аккерманського кадія/судді і до командира яничарського корпусу; листом кримського хана; документами канцелярії великого везіра та іншими відомчими вписуваннями щодо неправомірних дій перекупників зерна з Аджидере [3] i спекуляції у розрахунках з ногайцями Єдисанської орди, що було виявлено під час інспекції зернових складів у селищі Аджидере кримським володарем Селім Герей ханом. Зокрема, наголошувалось на утисках представників «Єдисанської орди, які їуть з місияь відстанню 20-30 годин шляху $і$ які привозили пшеницю, ячмінь, свіже молоко $і$ оброблені шкіри». Як вирішення цієї проблеми наказувалось «... від ияього часу і на майбутнє, все привезене з Сдисанської орди масло, пшениця і ячмінь, нехай не направляють до пристані Аджидере $i$ не продають торговиям, а всі згадувані продукти нехай довозять до пристані Ходжабей, щзоби відправити до столиці» [1].

Низка джерел наступного періоду 1780-90-х років позначають османську назву сучасного Овідіополя як і Аджидере, так і Гаджидере. Так у подорожньому описі французького інженера Лафитте-Клаве, який працював на військове відомство Османської імперії у 1784-87 роках зазначалось: «Гаджи-Дере, розташовано на іншій стороні ріки навпроти Аккермана, в затоиі чи западині ї̈ лівого берега, де його перетинає струмок, від якого селище отримало свою назву. Як розказують, воно було більше ніж Аккерман, але зруйновано росіянами під час минулої війни [1768-1774р.] $i$ не відновлено до попереднього стану» [9, с. 82].

Натомість в описі Очаківської землі здійсненого російським інженером ДеВоланом у 1791 році, говориться про Аджидере по закінченню російсько-турецьких війн, зазначаючи що: «положення Аджидері, вочевидь, було дуже привабливим під час його розквіту. ... Руїни, які засвідчують існування изього міста, мають близько трьох з половиною верст у периметрі. ... Молдовани, які мешкають в Калаглеї у 5 вестах звідси, говорять про Аджидері як про земний рай і особливо хвалять вино, яке тут робили, вважаючи його кращчим в усій Молдові та Бессарабії. ... Аджидері [до війни 1787-1791 р.] був найбільшим містом иієї провіниії після Очакова та мав, скоріш за все, досить значний ринок вивезення пшениці і худоби (переважно баранів) до Константинополя» [10, с. 99-100]. 
Принаймні до 1794 року російська адміністрація продовжує називати Овідіополь османською назвою Аджидере. Зокрема у дозвільних документах архіву Очаківської портової митниці щодо торговельної діяльності окремих купців, міститься справа «очаківського купця Георгія Врета, який вирішував питання безперешкодної доставки пшениці до Очакова від Аджидера для відправлення до Константинополя (1794р.)» [7].

Таке чергування назви Аджидере з Хаджидере/Гаджидере $\epsilon$ притаманним в османських найменуваннях при перекладі на інші мови. Таке ж чергування часто зустрічається в османській назві міста Одеса. Якщо більш давня назва Одеси у XVI ст. позначалась як Коджабей, то в XVII ст. частіше використовується Ходжабей. Однак у XVIII ст. наряду з назвою Ходжабей все частіше в кириличних і латиничних джерелах зустрічається найменування Хаджибей, Гаджибей чи Аджибей. Якщо для нетюркського джерела таке позначення є особливостями латинської і кириличної вокалізації османської назви Ходжабей, то при тюркському написанні назви Хаджибей, Гаджибей чи Аджибей отримуємо зовсім інше інформаційно-змістовне поняття при перекладі. Так само i османська назва Аджидере у порівнянні 3 Хаджидере / Гаджидере має різний зміст. «Аджи-дере» - буквально перекладається як «Гірка долина», натомість «Хаджи-дере / Гаджи-дере» у перекладі означає «Долина паломника».

Такі подвійні назви населених пунктів подеколи зустрічаються і в османських документах через незнання османською бюрократією топонімів віддалених регіонів Османської держави. Таким документом є османська карта 1790-го р. [4], про що свідчить зміст надписів і пояснень до населених пунктів. Зокрема на місці сучасного Овідіополя міститься напис:

«Розпочате здійснення будівництва фортеці в Хаджидере»

[Hacıdere'de inşâya mübâş̧eret eyledükleri kal'a]

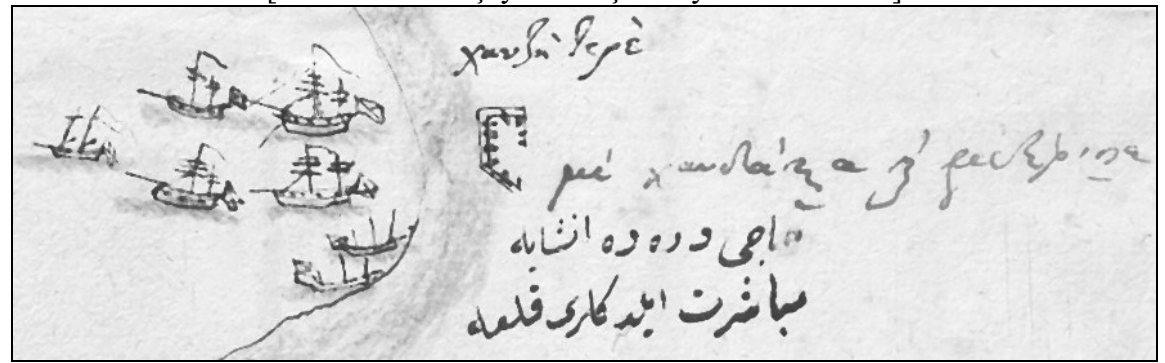

Початок будівництва фортеці в Аджидере розпочинається у 1790 р., тому саме за цим роком можна датувати османську карту, в архівній анотації до якої зазначається похибка дати на п'ятдесят років пізніше. Ще одним аргументом до датування карти саме 1790 р. є позначення незвичним чином проливів з Дністровського лиману до Чорного моря. Традиційно відоме Царгородське чи Стамбульське гирло позначено як Мусульманська протока. Натомість Очаківське гирло представлене як Московська протока. Отже, на карті зазначались сфери судноплавства, закріплені за османським (мусульманським) і російським (московським) флотами. До того ж, османська назва «Аджидере» на карті означена за російською вокалізацією «Гаджидере».

Натомість у центральному надпису на картографічному зображенні Дністровського лиману міститься надпис-пояснення відстані до Аккермана 3 притаманним османським написанням «Аджидере»: 
«3 Аккермана до фортеці Аджидере напряму є відстань у чотири - п’ять миль» [Akkerman'dan Acıdere kal'asına dek dört - beş mil mesafe vardır]

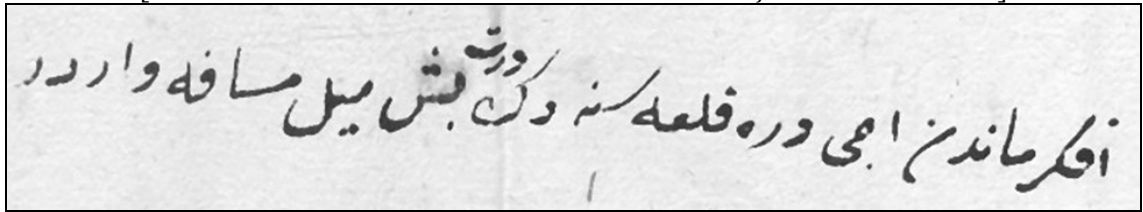

Отже, можна стверджувати щодо вживання османської назви Овідіополя Аджидере протягом другої половини XVIII ст. передусім в османських документах, а також назви Хаджидере чи Гаджидере як в османських, так і в інших джерелах. Принаймні з першої згадки в османських офіційних реєстрах від 26 вересня 1756 р. до часу повідомлення Очаковської митниці у 1794 р. існує історична тяглість, безперервність у вживанні назви населеного пункту як Аджидере.

\section{Карта глибин Дністровського лиману і протоків}

Додатки:

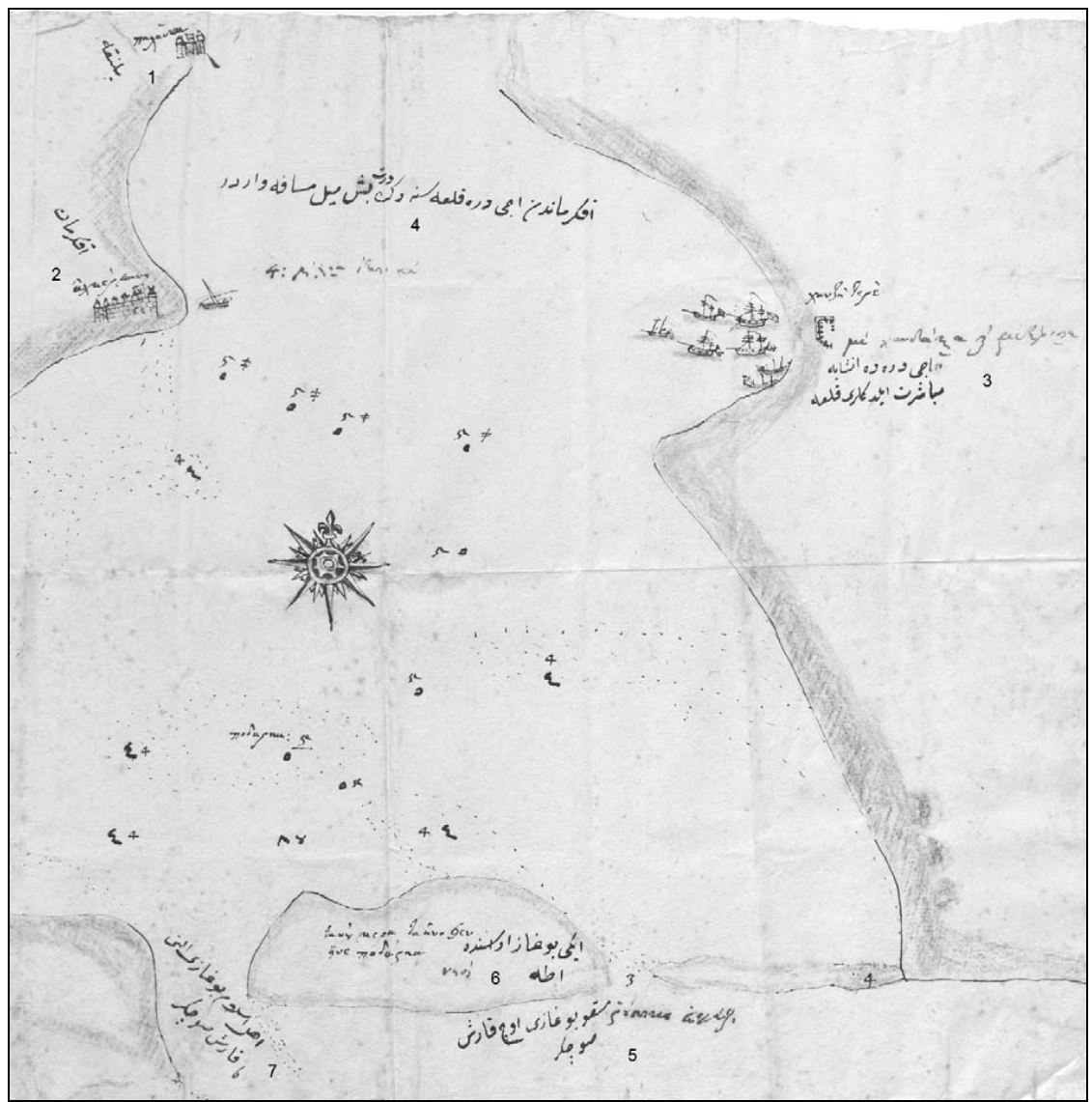


1 [Palanka] Паланка

2 [Akkerman] Аккерман

3 [Hacıdere'de inşâya mübâşeret eyledükleri kal'a]

Розпочате здійснення будівництва фортеці в Хаджидере

4 [Akkerman'dan Acıdere kal'asına dek dört - beş mil mesafe vardır]

3 Аккерману до фортеці Аджидере напряму є відстань у чотири - п'ять миль

5 [Moskov boğazı üç karış su çeker]

Московська протока глибиною на три ліктя

6 [iki boğaz arasında ada]

острів поміж двома проливами

7 [Ehl-i İslam boğazı altı karış su çeker]

Мусульманська протока глибиною на шість ліктів

Джерела та література:

1.Başbakanlık Osmanlı Arşivi (далі BOA). - Fon adı: “C.BDL.”. - Dosya № 38. Gömlek № 1865. [1178 Ş $21 / 13.02 .1765]$

2.BOA. Fon ad1: "C.HR." Gömlek № 1087. [1172 R 21 / 22.12.1758]

3.BOA. Fon adı: “D.MKF.d.”. Defter № 29796-Y. [1170 sene / 26.09.1756-14.09.1757]

4.BOA. Fon adı: "HAT.”. Dosya № 1387, Gömlek № 55149. [1768 - 1791].

5.Osmanlı belgelerinde Kırım Hanlı̆ 1 $=$ [Crimean Khanate in Ottoman documents]. İstanbul. 2013.

6.Аргатюк С. С. Аджидер-Овидиополь: очерки по археологии и истории города и крепости. /

С. С. Аргатюк, В. В. Левчук, И. В. Сапожников. - Одеса-Овидиополь, 2015. - С. 64-65.

7.Головко Ю. І. Матеріали фонду Очаківської портової митниці Державного архіву Миколаївської області як джерело 3 історії зовнішньої торгівлі Південної України кінця XVIII - початку XIX ст. / Ю. І. Головко // Історія торгівлі, податків та мита: збірник наукових праць. - 2012. - № 1. - С.60-67.

8.Середа О. Османсько-українське степове порубіжжя в османсько-турецьких джерелах XVIII ст. / О. Середа. - Одеса, 2015. - С. 210-214.

9. [Лафитте-Клаве] Описание пути от Константинополя до Очакова / [Лафитте-Клаве]. СПб., 1821.

10. Отчет относительно географического и топографического положения провинции Озу или Едисан, обычно называемой Очаковская степь, служащий пояснением к картам и планам, снятым по высочайшему указанию. 1792 г. // Наследие Ф. П. Де-Волана. Из истории порта, города, края. -Одесса. - 2002. - С. 99-100.

\section{References:}

1. Başbakanlık Osmanlı Arşivi (afterwards: BOA). Fon adı: "C.BDL.”. Dosya № 38. Gömlek № 1865. [1178 \$̧ $21 / 13.02 .1765]$.

2. BOA. Fon adı: "C.HR." Gömlek № 1087. [1172 R 21 / 22.12.1758]

3. BOA. Fon ad1: "D.MKF.d.". Defter № 29796-Y. [1170 sene / 26.09.1756-14.09.1757]

4. BOA. Fon adı: "HAT.”. Dosya № 1387, Gömlek № 55149. [1768 - 1791].

5. Osmanlı belgelerinde Kırım Hanlığ $=$ [Crimean Khanate in Ottoman documents], 2013. İstanbul. [in Turkish]

6. Argatiuk, S. S., Levchuk, V. V., Sapozhnikov, I. V., 2015. Adzhider-Ovidiopol: ocherki po arheologii i istorii goroda i kreposti. Odesa-Ovidiopol. [in Ukrainian]

7. Golovko, Yu. I., 2012. Materialy fondu Ochakivskoi portovoi mytnytsi Derzhavnogo arhivu Mykolaivskoi oblasti yak dzherelo z istorii zovnishnioi torgivli Pivdennoi Ukrainy kintsia XVIII pochatku XIX st. Istoria torgivli, podatkiv, ta myta: zbirnyk naukovyh prats, 1. [in Ukrainian]

8. Sereda, O., 2015. Osmansko Ukrainske stepove porubizhzhia v osmansko-turetskih dzherelah XVIII st. Odesa. [in Ukrainian] 
9. [Lafitte-Klave], 1821. Opisaniye puti ot Konstantinopolya do Ochakova. Sankt-Peterburg. [in Russian].

10. Otchet otnositel'no geograficheskogo i topograficheskogo polozheniya provintsii Ozu ili Edisan, obychno nazyvayemoy Ochakovskaya step', sluzhashchiy poyasneniyem k kartam i planam, snyatym po vysochayshemu ukazaniyu. 1792 g. In: Naslediye, F. P., 2002. De-Volana. Iz istorii porta, goroda, kraya. Odessa. pp. 99-100. [in Russian].

Отримано: 02.12.2020 p. 
ISSN 2519-2523 (print)

DOI: $10.18524 / 2519-2523.2020 .15 .218674$

УДК 94(477.74):271.2“1800/1900”

\title{
THE HISTORY OF THE DEVELOPMENT OF THE ODESSA TEMPLE KAZAN ICON OF THE MOTHER OF GOD
}

\author{
Natalia Dianova \\ ORCID: https://orcid.org/0000-0003-0406-6907 \\ DSc (History), Professor \\ Odessa I.I. Mechnikov National University \\ 2, Dvoryanskaya str., Odessa, 65082, Ukraine \\ dianova@onu.edu.ua
}

The purpose of the presented work is to highlight some aspects of the development of the Odessa Church of the Kazan Icon of the Mother of God in the context of its achievements and problems in the period of the XVIII - the end of the XX century. The use of descriptive and retrospective research methods made it possible to reproduce the vast majority of historical stories associated with the development of the temple.

The article analyzes the features of the process of preparation and construction of a Cossack church on Peresyp. The complex of archival documents used in this work makes it possible to reconstruct the development of the parish from the beginning of the XVIII century to 1920. The role of the inhabitants of the suburb and the clergy in the process of the development of the temple is studied. It was emphasized that the church made significant achievements in the late 19th-early 20th centuries. A significant role in this process was played by the priests $F$. Chemena, I. Shramkov, A.Gentus, N. Cheredyev and others.

It is indicated that in the history of the temple of the Kazan Icon of the Mother of God of the 20th century several periods can be distinguished: the heyday of the temple at the beginning of the century, the repressions of 1920-1930, the opening of the temple and the resumption of services during the Second World War, the confiscation of the premises in the early 1960 and finally, the return of the temple to believers in 1991.

Key words: Odessa, Peresyp, Cossacks, the temple of the Kazan Icon of the Mother of God, clergy.

Наталія Діанова

ORCID: https://orcid.org/0000-0003-0406-6907

Доктор історичних наук, професор Одеський національний університет імені I.I. Мечникова

Вул. Дворянська, 2, м. Одеса, 65082, Україна dianova@onu.edu.ua

\section{ІСТОРІЯ РОЗБУДОВИ ОДЕСЬКОГО ХРАМУ КАЗАНСЬКОЇ ІКОНИ БОЖОЇ МАТЕРІ}

Мета статті полягає у висвітленні основних аспектів розбудови Одеського храму Казанської ікони Божої Матері в контексті його досягнень та проблем упродовж XVIII кіния XX cm. Використання дескриптивного та ретроспективного методів дослідження дало можливість відтворити переважну більшість історичних сюжетів, пов'язаних із процесом розбудови храму. 
У статті проаналізовано особливості процесу підготовки та будівництва козацької церкви на Пересипу. Використаний у роботі комплекс архівних документів дає можливість реконструювати розвиток парафії з початку XVIII cm. до 1920 р. Досліджено роль жителів передмістя та духовенства в прочесі розбудови храму. Зазначено, що значних здобутків церква досягла наприкіниі XIX - на початку XX cm. Вагому роль у иьвому прочесі відіграли священики: Ф. Чемена, І. Шрамков, А. Гентус, М. Чередєєв та інші.

Наголошено, щчо в історії храму Казанської ікони Божої Матері XX cm. можна виокремити декілька періодів: розквіт на початку століття, репресіі 1920-1930 рр., відкриття храму $і$ відновлення богослужінь у період Другої світової війни, конфіскачія приміщення на початку 1960-х рр. i, нарешті, повернення храму віруючим у 1991 p.

Ключові слова: Одеса, Пересип, козачтво, храм Казанської ікони Божої Матері, духовенство.

Історія розбудови Одеського храму Казанської ікони Божої Матері, що знаходиться на Пересипу, безпосередньо пов'язана 3 козаками, що здавна проживали в цьому передмісті. Тож не даремно його називали спочатку козацьким або чорноморським, тому що частина козаків до поселення в місті належала до Чорноморської гребної флотилії. Коли внаслідок російсько-турецької війни (17871791 рр.) турецька фортеця Хаджибей відійшла до Російської імперії, а на іiї місці розпочалося активне будівництво міста-порту, то першими його жителями стали козаки й українські селяни, які раніше проживали в передмісті чи околицях фортеці, та чорноморські козаки, що були у Чорноморській гребній флотилії Й. Дерибаса. Останні утворили особливу слобідку або передмістя на Пересипу. У 1797 рр. козаки, що входили з 1794 р. до Чорноморської козацької команди на чолі з осавулом Ф. Черненко, отримали дозвіл на постійне проживаня в місті. Вони були приписані до станів одеських міщан або купців і займались здебільшого торгівлею, сільським господарством та видобутком черепашнику. Серед основних місць їх розселення був Пересип.

Питання заселення українськими козаками Пересипу частково розглядалося в працях дослідників XIX ст. Вони відзначали, що українське населення, значну частину якого становили запорозькі козаки, проживало на околицях Хаджибею ще в 70-х рр. XVIII ст. Зокрема, протоієрей С. Петровський писав, що на околицях Хаджибею проживав значний відсоток запорозьких козаків, які з 1775 р. за дозволом паші поселилися по балках: Нерубайське, Усатове та частково на Пересипу [15, с. 3.]. О. Маркевич стверджував, що ці околиці були густо заселені ще в 70-80-ті pp. XVIII ст. в основному українцями, які були досить заможними, займалися сільським господарством, городництвом, рибальством, видобутком солі з лиманів тощо. До того ж вони вели жваву торгівлю, поставляючи в Хаджибей продукти харчування [11, с. 126].

У сучасній українській історіографії з'явились дослідження, автори яких торкаються проблеми появи козаків на околицях Хаджибею та в передмісті Одеси. А. Д. Бачинський зазначав, що надзвичайно важливу роль у будівництві ХаджибеюОдеси протягом 1794-1797 pp. відіграли козаки, які були у Чорноморській гребній флотилії Й. Дерибаса. У відповідності з Генеральним планом Одеси 1798 р. для проживання чорноморських козаків відводилось так звана «Чорноморська слобідка» на Пересипу, де в подальшому планувалось будівництво Чорноморської церкви [1, с. 50].

Група одеських науковців у 2008 р. видала збірку «Одеса козацька», до якої увійшли й наукові розвідки Т. Гончарука та С. Гуцалюк, що стосуються питання появи чорноморських козаків в Хаджибеї-Одесі [13]. Особливий інтерес у контексті даного дослідження становить публікація «Генерального плана топографического города Одессы, крепости и порта, в каком ныне состоянии находится. 1798 г.». Згідно 
3 планом на Пересипу під номером 12 означена «Чорноморська слобода», а під номером 14 - майбутня Чорноморська церква [13, с. 60-61].

Проблемі запорозьких i чорноморських козаків у Хаджибеї та Одесі присвячено дослідження I. Сапожникова та Г. Сапожникової. Дослідники, зокрема, важають, що кількість козаків та їх родичів, які поселилися в 1797 р. в Одесі, сягала від 400 до 450 осіб, що становило майже 10\% від загальної кількості жителів міста $[16$, c. 73$]$.

Про певний зв’язок козаків з Пересипом згадував у своїй книзі О. Олійників, зазначавши, що «Саме до Хаджибейського Пересипу молодий запорозький козак у 1709 р. приніс Образ Покрови Пресвятої Божої Матері Непорочної Діви Марії, урятувавши його від полум'я» [14, с. 33].

В. Михальченко, який досліджує біографістику одеського духовенства, надав короткі біографічні довідки й тих священиків, які служили в міському храмі Казанської ікони Божої Матері [10].

У своєму монографічному дослідженні, яке стосується православного життя в Одесі упродовж 1917-1945 pp., М. Михайлуца згадував і про Казанську церкву на Пересипу, якої торкнулися усі перипетії того буремного часу [12].

Однак дослідники не розглядали проблему заснування та розбудови козацької церкви на Пересипу. 3 приємнісю можна зазначити, що протоієрей Одеського храму Казанської ікони Божої Матері Сергій Каюн підготував до друку книгу, яка стосується історії храму - «Духовный маяк Пересыпи», яку незабаром планує опублікувати (упорядник - одеський краєзнавець О. Чилей). Проте на даний період часу в історичній літературі бракує праць, присвячених історії храму, що робить представлену публікацію, яка виконана в руслі краєзнавчої тематики, достатньоо актуальною.

Мета статті полягає у висвітленні основних аспектів розбудови Одеського храму Казанської ікони Божої Матері в контексті його досягнень та проблем упродовж XVIII - кінця XX ст.

Козаки, які з кінця XVIII ст. проживали в передмісті Хаджибею-Одеси - на Пересипу, стали парафіянами трьох одеських православних церков, які знаходились в центрі міста. Тож на рубежі XVIII - XIX ст. постало питання про необхідність будівництва церкви в цьому районі. У Державному архіві Одеської області зберігаються документи, за допомогою яких можна репрезентувати непростий процес перемовин жителів Пересипу з світською та духовною владою Одеси щодо розбудови храму. Це, зокрема, звернення депутатів від цього району до генерал-губернатора графа М. С. Воронцова від 10 січня 1833 р. 3 проханням затвердити поданий ними план церкви Казанської Божої Матері та надати зручну ділянку землі під іiі будівництво [2, арк. 1]. Проте вказане звернення було подане без попереднього узгодження питання 3 правлячим архієреєм Димитрієм (Сулимою), що викликало незадоволення останнього.

Лише 28 вересня 1835 р. архієпископ повідомив Одеського градоначальника O. I. Левшина про те, що до нього з клопотанням про будівництво церкви Казанської Божої Матері звернулися депутати від Пересипу - купці Микола Кушнірьов, Дмитро Філіпов та Ієрофей Бондарєв. Вони надали план і фасад майбутньої церкви й обгрунтували ¥ї необхідність. Насамперед, у передмісті Пересипу проживають парафіяни трьох одеських церков: соборної Преображенської, Покровської й Успенської, загальною чисельністю 591 особа чоловічої статі та 5324 особи жіночої. Дорога до найближчої Преображенської церкви в негоду, особливо навесні та восени, 
розмита і пересуватися нею досить проблематично. До того ж у цьому передмісті проживає значна кількість розкольників, наявність церкви для яких може прискорити навернення в православ'я. Враховуючи усе вище зазначене, Димитрій (Сулима) звернувся до градоначальника 3 проханням призначити чиновника, який би разом 3 Одеським старшим благочинним протоієреєм Іоаковом Сотниченком грунтовно вивчили питання доцільності будівництва церкви [9, арк. 1-2].

Проте навіть вивчення питання затяглося на роки. Справа дещо пожвавилась коли Одеса стала кафедральним містом новоутвореної Херсонсько-Таврійської єпархії, яку очолив архієпископ Гавриїл (Розанов). Головна проблема на шляху спорудження церкви полягала в пошуках коштів. На середину 1842 р. існувало три проєкти майбутньої церкви. Перший із них був представлений депутатами від жителів Пересипу. Він складався 3 плану, фасаду і кошторису в 36172 крб. 20 1/2 коп. асигнаціями, проте він не був схвалений Головним управлінням шляхів сполучення $\mathrm{i}$ публічних приміщень. Другий проєкт був складений самою комісією Головного управління. Він складався 3 плану і фасаду у візантійському стилі, але не мав кошторису. На думку Гавриїла (Розанова) він міг обійтися в 60 тис. крб. Третій проєкт, за дорученням М. С. Воронцова, був підготовлений міським архітектором Г. Торрічеллі. Кошторис був складений у відповідності до зроблених ним креслень і переданий до Будівельного комітету [2, арк. 32, 51].

10 липня 1843 р. архієпископ отримав указ Св. Синоду, згідно з яким дозволялось будівництво кам'яної церкви на Пересипу. На будівництво виділялось кошти в кредит на 20 років під розписку попечителя купця Мелованова [2, арк. 55, 61, 65].

Церкву Казанської ікони Божої Матері на Пересипу закладено в 1844 р., побудовано на кошти парафіян й освячено 21 листопада 1846 р. Тоді ж Херсонською Духовною Консисторією церкві була видана метрична книга. Варто зазначити, що в документах XIX ст. церква здебільшого має назву «Казанська церква на Пересипу», рідше - «церква Казанської Божої Матері». У метричній книзі уже в 1846 р. зроблено перші записи, які засвідчують, що в листопаді - грудні серед парафіян церкви народилося 29 дітей і померло 19 осіб [5, арк. 445-489 зв.].

Церква була кам'яною, одно-пристольною. Згідно зі штатом при ній мало бути два священика, диякон, дячок і паламар. Проте священиком був лише один Фока Михайлович Левицький, який очолював церкву упродовж 1846-1872 рр. був. Він народився в 1799 р. у сім’ї священнослужителя, в духовній семінарії не навчався, тож спеціальної освіти не мав. Проте це не завадило йому зробити певну церковну кар'єру і поступово пройти шлях від паламаря до священика. У 1808 р. Катеринославським архієпископом Платоном (Любарським) його призначено в поміщицьке село Покровське паламарем Петро-Павлівської церкви, в 1816 р. переведено до поміщицького села Ковалівки дячком до Свято-Михайлівської церкви, а в 1829 р. - до Одеського кафедрального Преображенського собору. Згодом, у 1837 р. він став дияконом цього ж собору. 30 січня 1839 р. Ф. Левицький був висвячений в сан священика собору, а в 1846 р. його переведено священиком до Казанської церкви на Пересипу, служіння якій він присвятив решту свого життя.

Дияконом церкви 26 листопада 1846 р. призначено Олександра Івановича Гребенникова. Дячком став 25-річний Семен Фомич Камінський. Паламарем у листопаді 1946 р. призначено Олександра Миколайовича Фоміна [3, арк. 45-48].

Серед перших парафіян церкви переважну більшість становили колишні козаки, які здебільшого були записані до станів міщанства та купецтва. У 1848 р. до парафіян церкви Казанської ікони Божої Матері належало 1675 осіб: 828 осіб 
чоловічої і 847 осіб жіночої статі. Зокрема, 18 осіб духовного звання, 68 чиновників, 14 почесних громадян міста, 47 одеських купців, 787 міщан, 540 іногородніх, 28 нижніх чинів і 146 розкольників [3, арк. 49]. Слід зазначити, що в церковних документах під терміном “розкольники” часто фігурували як старовіри, так i представники низки сект: молокани, духобори скопці та інші. Офіційно до 1905 р. розкольниками називали прихильників старообрядництва або старовірів.

3 часом освітній рівень духовенства, яке служило в церкві Казанської ікони Божої Матері, стає більш високим. Наступним священиком після Ф. Левицького став Федір Федорович Чемена, який служив там з 1872 по 1894 рр. і зробив вагомий внесок у подальший розвиток парафії. Він був родом із Подільської губернії, тож навчався спочатку в Подільській духовній семінарії, потім перевівся до Херсонської духовної семінарії після закінчення якої (1861р.) був призначений законовчителем до дівочого училища при Одеському Архангело-Михайлівському жіночому монастирі. У 1862 р. він прийняв сан священика й служив спочатку в церквах Одеського повіту, а в 1872 р. Ф. Чемена був переведений священиком до церкви Казанської ікони Божої Матері. У 1894 р. його призначено до Успенської церкви, де він недовго встиг прослужити до своєї смерті (6 липня 1894 р.) [10, с. 504]. Його рідний брат Мартирій Федорович Чемена теж немало прислужився місту. Після успішної священницької діяльності він упродовж 1868-1900рр. здійснював плідне керівництво Одеською духовною семінарією.

У церковних документах за 1875 р. зазначено, що до парафіян церкви Казанської ікони Божої Матері належали 20 осіб духовного звання, 199 військових, 29 штатських, 744 купців і міщан та 113 розкольників [4, арк. 134]. Тож основну частину парафіян, як і раніше, складали колишні козаки, які дбали про розвиток своєї парафії. Спільними зусиллями парафіян та церковнослужителів у 1888 р. при церкві відкрито однокласну церковно-парафіяльну школу, де діти могли отримати початкову освіту. Організація навчального процесу та благодійність здійснювались за добровільні пожертвування парафіян.

У $1889-1896$ pp. настоятелем храму Казанської ікони Божої Матері був протоієрей Антоній Йосипович Гентус, який в 1865 р. закінчив Одеську духовну семінарію й рік після того прийняв сан священика. Спочатку він служив у храмах Одеського й Херсонського повітів та в Бериславі, звідки в 1889 р. його перевели до Одеси, до церкви Казанської ікони Божої Матері [10, с. 106]. А. Гентус доклав чимало зусиль для подальшої розбудови храму. У 1895 р. його значно розширили й добудували дзвіницю. Він став дво-престольний: головний престол називався в честь Казанської ікони Божої Матері, а другий - в честь Трьох Святителів. При храмі в 1897 р. організовано парафіяльне попечительство та недільна школа.

У XX ст. в історії храму Казанської ікони Божої Матері можна виокремити декілька періодів. Перший із них, найбільш успішний, розпочався в 1900 р. і тривав приблизно до початку 1920-х рр. У цей час до штату церкви входили два священики і два паламарі. Упродовж 1896-1911 pр. настоятелем церкви був протоієрей Іоанн Олександрович Шрамков, який свого часу закінчив Курську духовну семінарію. Одночасно він здійснював керівництво церковно-парафіяльною школою. Його плідна діяльність відзначена низкою нагород, у тому числі й орденом св. Анни 3-го ступеня.

Другим священиком 31900 по 1913 рр. служив Микола Михайлович Чередєєв. Він походив з дворян Тверської губернії. Навчався спочатку в Донській духовній семінарії, а потім перевівся до Одеської, яку успішно закінчив у 1888 р. У 1896 р. прийняв сан священика й був призначений до Миколаївського собору м. Бобринець. 
За плідну працю в Одеському відділі Імператорського Православного Палестинського товариства в 1899 р. став його пожиттєвим дійсним членом. 14 березня 1900 р. отримав призначення на вакантну посаду другого священика до храму Казанської ікони Божої Матері, де й прослужив до кінця свого життя. У цей час він успішно поєднував церковну діяльність 3 освітянською, працюючи законовчителем в народних училищах № 11 та 12 у домі Трігера на Московській вулиці, які належали до компетенції церкви [10, с. 507, 528 - 529].

Паламарями в зазначений період часу були Петро Кирилович Боруцький (з 1898 р.) і Сергій Никонович Мирошниченко (з 1905 р.).

У метричній книзі храму за 1900 р. зафіксовано народження 662-х немовлят. Шлюб у цей час взяли 250 осіб. Звертає на себе увагу той факт, що вінчалися особи, які належали до різних станів, національностей і навіть віросповідань. Серед молодят були міщани, селяни Подільської губернії, вільні матроси та інші. Один із наречених був Турецький підданий. 29 вересня 1900 р. протоієрей Іоанн Шрамков вінчав колишнього підданого Німеччини Іоанна Кюнера, який належав до лютеранського віросповідання, 3 православною дочкою миколаївського міщанина, 20-річною Степанидою Олексіївною Вольською [6, арк. 121, 150, 184].

У відповідності з довідником Херсонської єпархії за 1906 р. до парафії храму Казанської ікони Божої належало 287 дворів, а загальна чисельність парафіян становила 2158 осіб. Церковний капітал складав 1800 крб. Церква опікувалась чотирма міськими народними училищами і однокласною церковною школою [17, с. 28-29].

У період з 1913 по 1919 рр. настоятелем храму був Петро Васильович Брилєв, який в 1888 р. закінчив Одеську духовну семінарію. До призначення в храм Казанської ікони Божої Матері він поєднував церковну і освітянську діяльність в різних місцях Херсонської єпархії [10, с. 58]. Початок його перебування на чолі храму був досить сприятливим. Кількість парафіян мала чітку теденцію до зростання. У Метричній книзі за 1913 р. зафіксовано, що народилось 662 особи, вінчалося 256 осіб та померло 111 осіб. Найвищою, як і в попередні роки, була дитяча смертність. Зокрема, у віці до одного року померло 38 немовлят, а від одного до п'яти років - 13 дітей [7, арк. 258]. Проте подібна статистика була характерною для Російської імперії і пояснювалась недостатнім доглядом за дітьми, особливо в бідних сім'ях.

У непростому для країни 1918 р. основні показники парафії були менш втішними. У цей рік народилося 537 немовлят та померло 246 осіб. Дитяча смертність стала вищою: віком до одного року померло 56 дітей, від одного до п'яти років - 20, що на 25 осіб більше, ніж у 1913 р. [8, арк. 238]. Характерною особливістю осені та зими стала смертність парафіян від запалення легенів, чого не спостерігалося влітку. Так у вересні зафіксовано 18 таких випадків (усього померло 33 особи), а в грудні 13 (у цьому місяці померло 49 осіб). Крім того, у грудні під час боїв було вбито 31 особу [8, арк. 207-237]. Попри усі негаразди у церкві в 1918 р. взяли шлюб 229 осіб. Причому, серед парафіянок, що одружувались в цей час, були представниці різних станів. Зокрема: козачка Свдокія Пархоменко, селянка Марія Жуматій, міщанка Олена Олійниченко, дочка особистого почесного громадянина Надія Петровська та інші [8, арк. 139-207].

Революційні події, які відбувались в Одесі, не могли не позначитись на життєдіяльності парафіян храму. Тож у 1919 р. статистичні показники парафії були дещо гіршими, ніж у попередньому році. Народилося лише 222 дитини, одружилося 225 осіб і померло 215 осіб [8, арк. 239-370]. 
3 1920-х до 1936 pp. розпочався другий етап в історії храму. Він віддзеркалював загальну політику радянської влади до релігії в цілому, спрямовану на іiі знищення. Це був час утисків, грабунків і репресій по відношенню до церкви та духовенства. У 1936 р. приміщення храму будо конфісковано владою й там розташували казарми моряків.

Третій період розпочався в період Другої світової війни. У 1941 р. Румунська православна місія одним із першочергових завдань в Одесі вважала повернення відібраного більшовиками майна і власності, які належали єпархіям та церквам, відкриття та освячення діючих та відремонтованих церков тощо. Тож уже в листопаді 1941 р. здійснювалось богослужіння в п'яти церквах міста, в тому числі й в храмі Казанської ікони Божої Матері [12, с. 207]. Проте згодом за розпорядженням радянської влади храм знову був закритий, а в його приміщенні в 1962 р. розмістили магазин меблів.

31991 р. розпочався четвертий період, який характеризується відродженням храму. У відповідь на чисельні прохання приміщення храму повернули віруючим, але воно потребувало значної реконструкції. Завдяки зусиллям деяких парафіян та благочестивій стариці черниці Пантелеймоні, збереглися головні церковні цінності, в тому числі й чудотворна ікона Божої Матері «Живоносне джерело на камені». У 1996 р. митрополит УПЦ Агафангел (Саввін) освятив приміщення храму, а згодом, уже на початку XXI ст. - купола, дзвіницю та новий іконостас. Тож храм Казанської ікони Божої Матері отримав нові можливості для свого подальшого розвитку.

\section{Джерела та література:}

1.Бачинський А. Д. Хаджибей-Одеса і українське козацтво / А. Д. Бачинський // Тези доповідей міжнародної науково-теоретичної конференції 6-8 вересня 1994 р. Одеса, 1994. Ч.1. - С. 49-51.

2. Держархів Одеської області. - Ф. 1. - Оп. 191. - Спр. 71.

3. Держархів Одеської області. - Ф. 37. - Оп. 2а . - Спр. 497.

4. Держархів Одеської області. - Ф. 37. - Оп. 2а. - Спр. 577.

5. Держархів Одеської області. - Ф. 37. - Оп. 3. - Спр. 844.

6. Держархів Одеської області. - Ф. 37. - Оп. 13. - Спр. 370.

7. Держархів Одеської області. - Ф. 37. - Оп. 13. - Спр. 932.

8. Держархів Одеської області. - Ф. 37. - Оп. 13. - Спр. 1205.

9. Держархів Одеської області. - Ф. 59. - Оп. 2. - Спр. 454.

10. Духовенство Одессы / авт.-сост. А. В. Михальченко. - Одесса: «ТЕС», 2012. - 559 с.

11. Історія Хаджибея (Одеси) 1415-1795 pр. в документах / за ред. канд. іст. наук Т. Г. Гончарука. - Одеса: Астропринт, 2000. - 372 с.

12. Михайлуца М. Православне життя в Одесі: від революції до сталінського одержавлення (1917-1945). / М. Михайлуца. - Херсон: Олді-плюс, 2019. - 388 с.

13. Бачинська О. А. Одеса козацька. Наукові нариси / Бачинська О. А., Гончарук Т. Г., Гуцалюк С. Б. - Одеса: Фенікс, 2008. - 240 с.

14. Олійників О. Наснага одеської душі: одеські храми та добродійні товариства і осередки./ О. Олійників - Одеса: Астропринт, 2008. - 240 с.

15. Петровский С. Одесский кафедральный Преображенский собор. / С. Петровский. - Одесса: тип. Е. И. есенко, 1894. -123 с.

16. Сапожников И. В. Запорожские и черноморские казаки в Хаджибее и Одессе. / И. В. Сапожников, Г. В.Сапожникова. - Одесса: ОКФА, 1998. - 270 с.

17. Справочная книга Херсонской епархии. - Одесса, 1906. - 757 с. 


\section{References:}

1.Bachyns'kyy, A. D., 1994. Khadzhybey-Odesa i ukrayins'ke kozatstvo. Tezy dopovidey mizhnarodnoyi naukovo-teoretychnoyi konferentsiyi 6-8 veresnya 1994 r. Odesa, Ch.1, p. 49-51 [in Ukrainian].

2.Derzharkhiv Odes'koyi oblasti (The State Archives of the Odessa region (Ukraine)). F. 1. Op. 191. Spr. 71 [in Russian].

3.Derzharkhiv Odes'koyi oblasti (The State Archives of the Odessa region (Ukraine)). F. 37. Op. 2a. Spr. 497 [in Russian].

4.Derzharkhiv Odes'koyi oblasti (The State Archives of the Odessa region (Ukraine)). F. 37. Op. 2a. Spr. 577 [in Russian].

5.Derzharkhiv Odes'koyi oblasti (The State Archives of the Odessa region (Ukraine)). F. 37. Op. 3. Spr. 844 [in Russian]..

6.Derzharkhiv Odes'koyi oblasti(The State Archives of the Odessa region (Ukraine)). F. 37. Op. 13. Spr. 370 [in Russian].

7.Derzharkhiv Odes'koyi oblasti(The State Archives of the Odessa region (Ukraine)). F. 37. Op. 13. Spr. 932 [in Russian].

8. Derzharkhiv Odes'koyi oblasti(The State Archives of the Odessa region (Ukraine)). F. 37. Op. 13. Spr. 1205 [in Russian].

9. Derzharkhiv Odes'koyi oblasti(The State Archives of the Odessa region (Ukraine)). F. 59. Op. 2. Spr. 454 [In Ukrainian].

10. Mikhal'chenko, A. V., 2012. Dukhovenstvo Odessy. Odessa: «TES», 559 p. [in Russian].

11. Honcharuk, T. H., 2000. Istoriya Khadzhybeya (Odesy) 1415-1795 rr. v dokumentakh. Odesa: Astroprynt, 372 p. [In Ukrainian].

12. Mykhaylutsa, M., 2019. Pravoslavne zhyttya v Odesi: vid revolyutsiyi do stalins'koho oderzhavlennya (1917-1945). Kherson: Oldi-plyus, 388 p. [In Ukrainian].

13. Bachyns'ka, O. A., Honcharuk, T. H. \& Hutsalyuk, S. B., 2008. Odesa kozats'ka. Naukovi narysy. Odesa: Feniks, 240 p. [In Ukrainian].

14. Oliynykiv, O., 2008. Nasnaha odes'koyi dushi: odes'ki khramy ta dobrodiyni tovarystva $i$ oseredky. Odesa: Astroprynt. 240 p. [In Ukrainian].

15. Petrovskiy, S., 1894. Odesskiy kafedral'nyy Preobrazhenskiy sobor. Odessa : tip. E. I. Fesenko, 123 p. [in Russian].

16. Sapozhnikov, I. V. \& Sapozhnikova, G. V., 1998. Zaporozhskie i chernomorskie kazaki v Khadzhibee i Odesse. Odessa: OKFA, 270 p. [in Russian].

17. Spravochnaya kniga Khersonskoy eparkhii, 1906. Odessa, 757 p. [in Russian].

Отримано: 02.12.2020 p. 
ISSN 2519-2523 (print)

DOI: $10.18524 / 2519-2523.2020 .15 .218675$

УДК 94(477.7) “1804-1886”

\section{CONVERSION TO ISLAM AMONG EMIGRANTS FROM UKRAINE IN THE MIDDLE OF THE XIX CENTURY: THE CASE OF MYCHAYLO CZAJKOWSKI (MEHMED SADYK-PASHA)}

\section{Volodymyr Poltorak}

ORCID: https://orcid.org/0000 000304066907

PhD (History), Associate Professor

Odessa I.I. Mechnikov National University

2, Dvoryanska Str., Odessa, 65082, Ukraine

poltorak@onu.edu.ua

In the middle of the 19th century, the multi-ethnic and multi-religious Ottoman Empire gave refuge to representatives of the national liberation and revolutionary movements in Central and Eastern Europe. The popularity of Orientalism in Western culture has opened up to Europe the riches of Islamic cultural heritage. One of the participants in this process was a popular novelist, politician, military man from Volyn Mychaylo Czajkowski.

In 1850, along with many refugees and emigrants, Mychaylo Czajkowski converted to Islam and lived in the Ottoman Empire for almost three decades. His writings and correspondence allow us to trace how he perceived the Islamic Empire from within, how he perceived the Islamic religion from the point of view of a newly converted Muslim. His case is characteristic and unique at the same time, it allows a different look at Ukrainian-Islamic contacts in modern times.

The work of Sadyk Pasha, who opened the veil of the Islamic world to the Ukrainian, Polish, French, and Russian readers, should be singled out. The images of the Muslim, the Turk, the Ottoman were humanized by him, the barriers of misunderstandings and accusations were shaken. The past of the relationship is filled with examples of cooperation. The future looks full of joint projects and accomplishments. Sadyk Pasha's personal destiny testifies to understanding, to the tolerance of evaluation - to the expansion of the values of modern times.

Key words: Mehmed Sadyk-pasha (Myhaylo Czajkowski), Ottoman Cossacks, conversion to islam.

Володимир Полторак

ORCID: https://orcid.org/0000 000304066907

Кандидат історичних наук, доцент

Одеський національний університет імені I. I. Мечникова

Вул. Дворянська, 2, Одеса, 65082, Україна

poltorak@onu.edu.ua

\section{НАВЕРНЕННЯ НА ІСЛАМ СЕРЕД ЕМІГРАНТІВ 3 УКРАЇНИ У СЕРЕДИНІ ХІХ СТ.: ВИПАДОК МИХАЙЛА ЧАЙКОВСЬКОГО (МЕХМЕДА САДИК-ПАШІ)}

Мультиетнічна та різноконфесійна Османська імперія у середині XIX cm. дала прихисток представникам національно-визвольних та револючійних рухів ЦентральноСхідної Свропи. Популярність орієнталізму в західній культурі дозволила відкрити для Свропи багатства ісламської культурної спадщини. Одним із учасників цьього процесу став популярний романіст, політик, військовий Михайло Чайковський (Садик-паша). 
У 1850 р. разом з багатьма біжениями та емігрантами Михайло Чайковський прийняв іслам та майже три десятиліття жив в Османській імперії. Його твори та листування дозволяють прослідкувати, як він сприйняв імперію зсередини, як сприймав релігію з точки зору новонаверненого мусульманина. Його випадок характерний $і$ унікальний водночас, дозволяе по- іншому подивитися на українсько-ісламські контакти в модерну добу.

Окремо слід виділити творчість Садик-паші, яка відкрила украӥнському, польському, франиузькому, російському читачеві завісу ісламського світу. Образи мусульманина, турка, османа олюднюються, бар'єри непорозумінь та звинувачень розхитуються. Минуле відносин наповнюється прикладами співпраці. Майбутнє виглядає сповненим спільними проектами та звершеннями. Особиста доля Садик-паші свідчить про порозуміння, про толерування “інакшості" - про поширення цінностей модерного часу.

Ключові слова: Мехмед Садик-паша (Михайло Чайковський), навернення в іслам, османські козаки.

Мультиетнічна та різноконфесійна Османська імперія у середині XIX ст. дала прихисток представникам національно-визвольних та революційних рухів ЦентральноСхідної Свропи. Популярність орієнталізму в західній культурі дозволила відкрити для Свропи багатства ісламської культурної спадщини. Одним із учасників цього процесу став популярний романіст, політик, військовий Михайло Чайковський [6].

«Саме тоді, коли кирило-мефодіївиі задумались над тим, щзо Україна - камінь наріжний слов'янського світу, коли на вулииях Левового міста замайорів жовтосиній стяг руського люду, в Махнівці на межі Волині, Поділля та Київщини молодий хлопчина із захопленням читав «Козацькі повісті» та «Вернигору» волинського емігранта Чайковського. Молодому хлопчині на все життя запам'ятались романтичні характери та епічні постаті, які захопили його народною історією. Вихований в польскому шляхетському середовищі, він «одкрив сам собою украӥнство». Пізніше він створить наукову иколу, стане професором Київського університету, вчителем Михайла Грушевського. А починалось для Володимира Антоновича все зі сторінок «Могили» та інших повістей Михайла Чайковського. При цььому факт, щзо його улюблений автор є мусульманином жодним чином не зупиняв майбутнього лідера громадівського руху в захопленні творами свого кумира [5, с. 175].

Почавши дослідження козацтва як історик та письменник, Чайковський очінив $i$ політичні вигоди козакофільства. Створений ним у 1853 р. козаџький підрозділ у складі османської армї став єдиною можливістю для балканських християн отримати військову освіту та бойовий досвід. Ідеї демократії та національної держави виховувались вже самим духом, щуо панував у козацько-османських полках. Плануючи звільнити слов'янські народи від тиранії, вступити на чолі козацької армї до Києва, Чайковський водночас дбав про поширення освіти, про налагодження культурних мостів між поляками та болгарами, старообрядиями та украӥниями, турками та євреями.

Коло Гальчиния височіла Могила,

В ї̈ підніжжі роздоріжжя перетиналося, наче рамена хреста;

Зверху вона заросла кущами й зіллям,

А всередині, можливо, ховала пам'ятки минулого...»

Так почав видану в Парижі у 1837 р. одну зі своїх перших «повістей козацьких» Михайло Чайковський - 33-літній українськи шляхтич-емігрант. Все життя він марив минулим, яке можлливо ховається в могилі при роздоріжжжі, усе заросле кущами і зіллям. I все життя марення про козацькі часи, про «дружбу народів», бенкети і співи, полювання i верхові герці, шалене кохання i рівність межи людьми штовхали «Михалка з Гальчинця» до нових пригод, нових подорожей і нових життів. 
Від батька отримав він прізвище Чайковський, від діда по матері ім'я архангела Михайла, султан турецький пойменував його при наверненні до ісламу Мехмедом Вірним (Садиком), а сам себе звав він Чайкою - птахом морським і бездомним. Волів бути для світу пророком Вернигорою, а став для нього потурнаком Садик-пашею, підписував себе Гетьманом, а отримав від жорстокого біографа зневажливих епітетів «pół poeta, pół rycerz, pół uczony, półgłówek, pól dyplomata, pół narwaniec i do tego pół Polak» [7, c. 86].

Життя мав довге - 82 роки - комусь стало б на три життя. А йому вистачило на чотири. Чотири життя в чотирикутнику європейських столиць. Трагізму його долі додали біографи - сам він життя любив, ним насолоджувався, і смерті самогубця собі не шукав. Його діти довго не могли повірити у добровільність відходу батька на той світ... .

Станіслав Чайковський гербу Jastrzębiec - батько новонародженого Михайла невдовзі відійшов на той світ. Юнака виховувала мати та іiі рідня - шляхтичі Глембоцькі. Михайлова мати Петронела (в дівоцтві Глембоцька) доводилась правнучкою козацькому гетьманові Іванові Брюховецькому. Цим генеалогічним зв'язком з Гетьманщиною Михайло буде пишатись усе життя.

В старості він із захопленням змалював своє дитинство та парубоцтво на батьківщині. Було там усе - шляхетські розваги, бердичівські ярмарки, лови з хортами, навчання в ліцеї англійця Вольсея та школі братів-піарів в Межиріччі Корецькому. Михайло вперше закохався - в Северину Залевську з Пилип, що в 20 кілометрах на захід. Недосвідчений романтик при рідних тітках коханої визнав, що любить ії̈ наче свого коня, викликавши таким порівнянням неабияке обурення присутніх.

Акценти у спогадах про юність знакові - розповіді про фельдмаршала Івана Гудовича, знайомство з Тимком Падурою, Вацлавом Жевуським, Боніфатієм Антоновичем, Петром Гулаком-Артемовським. «Першим моїм учителем був пан А(нтонович), пристрасний українець-козак, і більшу частину своїх уроків я брав верхи на коні. Крім цього вчителя в мене був старий дядько на ім'я Левко, який оповідав мені казки про знахарів та чаклунів, передавав козацькі історії, показував урочища, в яких відгомоніли криваві баталії, та співав козацькі думи». Свій перший навчальний заклад - Бердичівську гімназію англійця Вольсея - Чайковський красномовно зве «слов'янською мозаїкою», де «дух козацький панував, бо вчителі були гарячими українцями». В цьому «бердичівському гуртку готувались запорозька старовина, думи про українських гетьманів, пісні козацькі та малоруські, які згодом вийшли в Харкові, куди перейшли в університет професорами» усі згадані вчителі.

Молодий шляхтич не стояв осторонь польської політичної боротьби - він був близький до студентських таємних товариств у Варшаві, і коли вибухнуло листопадове повстання, активно до нього долучився. Карл Ружицький (одружений на сестрі Чайковського) сформував волинський повстанський полк і у складі цього підрозділу Михайло бився «За нашу і вашу Свободу», а після поразки перетнув кордони Російської імперії. Саме з ганку свого палацу межи чотирьох колон оголосив він своїм селянам про волю - і закликав їх долучатись до боротьби 3 російською тиранією. Саме звідси, 3 Гальчинецького палацу почалось вигнання, почалась еміграція.

Молодий Чайковський не одразу потрапив до аристократичного готелю «Ламбер» - 1830-ті роки минули в пошуках однодумців та засобів для життя. Юнакові довелось пропонувати свій хист кавалериста та військового аналітика - його статті звернули на себе увагу міністра і колишнього наполеонівського маршала Сульта. Михайло почав писати репортажі з судових засідань, став кореспондентом 
декількох французьких газет. На той час він належав до демократичних кіл польської еміграції, проте згодом почав «дрейф вправо».

Палка пристрасть увінчалась першим одруженням - із Леонідою Габаре, молодою й чарівною дочкою архітектора міста Бурже. Французька дружина відіграла в його житті велику роль - правила чернетки статей та книжок, а згодом народила Михайлові чотирьох дітей [1, с. 254].

Рішучий вплив на молодого журналіста справив Адам Міцкевич - писати польською мовою була його порада. Перша книжка - і шалений успіх «Козацьких повістей» (1837). Потім були повісті та романи «Вернигора» (1838), «Кірджалі» (1839), «Гетьман України» (1841) etc. Ставши популярним письменником, Чайковський продовжив марити українською козаччиною. В Україні уважно читали твори земляка - Тарас Шевченко під час підготовки «Гайдамаків» вивчав «Вернигору», Володимир Антонович із захопленням гортав сторінки козацьких повістей і згодом віддав належне їхньому впливові, визнавши одним 3 чинників відходу від польськості до українськості...

31835 р. Чайковський став співробітничати 3 Французьким Історичним інститутом, який організував у Парижі «Європейський Історичний Конгрес». Виступаючи як спеціаліст з історії козацтва, він виголосив на Конгресі доповідь про вплив козацтва на розвиток літератури. Знаковою виглядає ідентифікація Михайла на Конгресі - серед французів, поляків, турок, росіян та інших народів останнім в переліку згадується «один Козак». У 1841 р. цей «Козак» Чайковський їде 3 документами Історичного інституту до Османської імперії для розшуків козацької старовини. Історична експедиція відкрила перед Михайлом на Сході безкраї можливості. Стамбул саме переживав реформи Танзімату [8, с. 12].

В готелі «Ламбер» Михайло Чайковський запропонував Адаму Чарторийському свої послуги - і очолив Східну Агенцію польського уряду в еміграції. Цей період діяльності яскраво висвітлений в польській та болгарській історіографії - завдяки збереженому листуванню 3 Адамом Чарторийським. У 1840 -х роках Чайковський патронує утворення окремої церковної ієрархії у старообрядців - втікачів з Росії, домагається відділення від вселенського патріархату болгарської церкви, веде жваве листування з агентами в Бухаресті, Тульчі та Белграді. Російська дипломатія почала бити на сполох - Микола I особисто вимагав усунення Чайковського зі Стамбула. Шеф жандармів Олексій Орлов в доповідній записці про розкриття КирилоМефодіївського товариства зазначив, що керує усіма антиросійським діями «Чайковський, який перебуває в Константинополі»... [4, с. 295]. Одразу ж за справою Кирило-Мефодіївського товариства та придушенням Угорського повстання, розпочала російська дипломатія кампанію проти Михайла Чайковського.

В лютому 1849 р. російське посольство у Стамбулі відновило запити щодо видалення Чайковського з берегів Босфора та його агента Ленуара з Белграду. Цього разу сподівань, що зусилля російської дипломатії будуть марними, не було. Ленуар одразу поступився. Хворий, не дужий після кавказької експедиції, виїхав до Парижа. Чайка вчинив інакше. Не міг і не хотів залишати Стамбула. Бачив, що Туреччина не зможе сама його оборонити. Тільки спільні зусилля 3 французькою дипломатією змогли б врятувати його становище. Він намагався затягнути справу, сподіваючись на появу нових можливостей.

Нові можливості не з'являлись, а російське посольство вже категорично вимагало екстрадиції Чайковського. Михайло пішов «ва банк». Він заявив, що якщо Туреччина його не захистить, а Франція відмовить в допомозі - віддасть себе в руки 
Росії. «Я переконаний, що моя позиція відмови від добровольної екстрадиції, натомість здача Москві на певне покарання, а не на ласку, має дошкульно вдарити по Порті та Франції».

Князь Адам Чарторийський суворо прокоментував таку позицію. Але Чайковський не поступався: «Я вимагав, що якщо збираються мене видворити, то нехай завезуть до Одеси разом $з$ агенцією». Ту саму тактику поведінки він вже використав у 1836 р., коли був під загрозою екстрадиції з Парижа: «Якщо виселятимете, - заявляв у префектурі, - віддамся царю до солдатів, на шибеницю». Щоправда наївно було би вважати, що такі заяви вплинули на французьку поліцію.

На захист Чайковського встав новий французький посол генерал Опік. Він нагадував своєму керівництву про заслуги з боку Чайковського, які ті здійснював стільки років як в Туреччині, так і у Франції. При цьому запевняв, що немає жодних доказів антиросійських діянь Чайки у самій Російській імперії. А те, що Петербургові не подобається його діяльність, авторитет серед слов'янських народів, не подобаються послуги, надані Туреччині - не повинно схиляти французький уряд до поступок. Про Чайковського посол висловлювався із щирою симпатією. Проте міністр іноземних справ генерал Ла Хітте вирішив справу суто формально Чайковський не натуралізований француз, користується лише протекцією Франції, $\mathrm{i}$ нема підстав не піти назустріч вимогам росіян.

Чайковський вбачав недостатніми зусилля готелю «Ламбер» в напрямі вирішення його справи. Особливо звертав увагу на лицемірну гру графа Владислава Замойського, з яким фактично перебували у стані конфронтації. Припускав, що граф намагається використати ситуацію і замість Чайковського на чолі Агенції Східної поставити бажає свого агента Косцєльського.

4 листопада 1850 р. посол Опік з великою прикрістю повідомив Чайковського, що французький уряд відмовив тому в протекції. Розчарований у французькій позиції, той сам взяв на себе відповідальність щодо власної долі. Розумів, що повернення до Парижа не вирішить проблеми, бо там очікував продовження цькувань. Тому відповів французькому послові: «Повернувшись до Парижа, не матиму жодної певності, що не буду далі висланим і вимушеним поїхати до Америки, якщо б того закортіло уряду петербурзькому». А далі Михайло засвідчив своє бажання знайти інше вирішення проблеми.

Мислив у ті тяжкі часи прийняття рішення: «Держава Османська на моє переконання це єдина організована антимосковська сила, і рано чи пізно між тими державами наступить битва остаточна, до котрої обидві сторони готуються... В Царгороді замайорів польський стяг... Бог так присудив, аби я був тим хто той стяг встановив... Уряд петербурзький відчув ту перешкоду i розсудив, що найпрактичнішим засобом повалення того стягу, було примусити мене до втечі чи відступу» [1, с. 293].

Турки щиро раді були його залишити, але після скасування французької протекції відчували слабкість позицій перед Петербургом. Право остаточного рішення належало султанові, але й він вагався. Саме в цей момент 3 наближених до Абдул-Меджида кіл вийшла пропозиція пристати Чайковському до ісламу.

Пізніше Чайковський в листі до князя Чарторийського відзначив: «Султан відзначив Решид-паші і мені через Етхем-пашу, що не підтримує мого повернення до Парижу, не підтримує мого виїзду 3 Туреччини, але бажає, аби я став мусульманином... і таким чином опинюсь під протекцією султана, стану вузлом, що зв'яже султана 3 князем і Польщею». 
В пізнішій розмові 3 Етхем-пашею Чайковський висловив свої заперечення: «Зазначив, що дві речі утримують від того кроку - недовіра до сили та рішучості турецького уряду та погляд на думку поляків, котра той вчинок сприйняла б, як негідну комедію... Таке рішення є натуральне в цей момент, проте скомпрометує моє добре ім'я для Польщі». Зазначив, що якщо б його за вимогою Росії екстрадирували як і генерала Юзефа Бема в якісь віддалені провінції, не був би тоді корисний ані Туреччині, ані Польщі.

У відповідь запропоновано йому, щоби висловив свої вимоги султанові особисто. Розмови ці точились в таємниці, до якої мали доступ декілька осіб 3 султанського оточення.

Проводячи переговори з Туреччиною, Чайковський не втрачав надії, що якесь «диво» вирве його з такого становища. Чарторийський теж шукав варіанти. Хтось навіть запропонував Чайковському отримати американське громадянство. Були здійснені навіть певні кроки в цьому напрямі. Проте усім цим зусиллям завадило наступне листування.

Владислав Замойський до Михайла Чайковського. Париж, 26 листопада 1850. «Не знаю, чи повинен тобі писати. Не знаю, чи лист цей застане, не знаю - аж мороз душу бере - i питання мене хвилює, ким ти зараз є! Не відаю, якою мовою звідти писатимеш... На все маєш мені відповісти. Всі аргументи, всі почуття найсердечніші і найсуворіші слова не виправдовують дивного незрозумілого рішення твого... I вчинок, який задумав, навіть в задумі $є$ зрадою, а недовіра буде вічним соромом не лише для тебе самого, а для нащадків твоїх, для Польщі, котра лише як зрадника буде тебе вважати... Бажаю, аби публічно усунувся від агенції. По багаторічній праці $є$ певна хвала і в самовольному залишенні агенції. То сьогодні моя порада, не повідомив ще князеві. Але якщо не дослухаєшся, князь дізнається про все».

Відповідь Михайла Чайковського Замойському. Стамбул, 5 грудня 1850 p. «Полковник, мені радиш піти 3 агенції добровільно і передати справи панові Косцєльському... Що ж, по усуненню з агенції і передачі усіх справ, буду вільним розпоряджатися власною особою».

В готелі «Ламбер» з неприємним здивуванням отримано депешу про передачу справ від Чайковського графові Владиславові Косцєльському. У відповідь надіслана від Чарторийського депеша: «Об’явити агенту головному (М.Чайковському) утриматися до останнього і не поступатись... і не складати управління, тільки за крайніх умов». Отже, Адам Чарторийський не розгадав макіавелівських інтриг свого племінника Владислава Замойського, але й не підтримав рішення Чайковського про залишення посади головного агента у Стамбулі. В тій самій депеші 17 грудня від Чарторийського до Чайковського проінформовано останнього про кроки до отримання йому американського громадянства, яке давало б йому можливість залишитись у Стамбулі. «Турки люблять і вміють затягувати справи, і якщо тягнуть їх вже стільки часу, то ще півтора місяці потягнуть, доки сподівана натуралізація (прийняття американського громадянсвта) нас урятує».

Проте було запізно. Доля Чайковського була вирішена, і той повідомив в готель «Ламбер»: «Завтра приймаю іслам і стаю підданим султана Османської держави... Моє життя політичне напевне скінчилось, але я переконаний, що мету, яку поставив, досягнув. Султан і каліф, приймає мене за свого підданого... I водночас, хто б не став на моє місце, стяг пана князя зостанеться піднятим в Царгороді - для Поляків, для Русинів, для Слов'ян...» 
Владислав Косцєльський натомість пише до Владислава Замойського 3 Пери (район Стамбула) 29 грудня 1850 р. «Ото як гром впала на мене звістка про перехід Чайковського до ісламу... Чайка приховував своє рішення, аби його не змогли від нього відмовити. Не можемо подолати нещастя цього, маємо тепер шукати користь для справи. Може бути ця користь велика, а тому заклинаю, пане полковнику, в ім'я душі твоєї, в ім'я стільки разів доведеного патріотизму, не дратуй того чоловіка. Якщо не маєш до нього добрих слів, то принаймні не картай суворо... Був у генерала Опіка. Зустрів не суворого суддю, а змученого приятеля. Так був розчулений, що за декілька хвилин тримав мою руку і слова вимовити не міг... Тітов (працівник російського посольства у Стамбулі. - В. П.) бажав, щоб Чайковського було інтерновано, але султан йому відмовив. Чайковський відмовився від усіх надань, бажав нужду терпіти, але не прийняти від турків нічого. Врешті, в такому нервовому становищі перебуває, що ніхто до нього приступити не може».

Про свій крок Чайковський без затримки надіслав повідомлення Юзефу Бему, який перебував в Алеппо і прийняв іслам у 1848 р. Проте це повідомлення вже не застало того в живих - Бем помер 10 грудня 1850 р. [1, с. 297]. Новий розділ біографії Чайковський розпочав на самоті, вибудовуючи самостійно свою подальшу політичну кар'єру в Османській імперії.

Чайковський ніколи не був фанатичним католиком, питання віри для нього стояло далеко не на першому плані. Пізніше, вже залишивши Османську імперію, він спокійно охрестить свою дочку за православним обрядом і проситиме російського монарха стати ії хрещеним батьком.

У своїх спогадах Михайло Чайковський пригадує випадок, який стався із ним новонаверненим мусульманином у наданому йому чифліку Сазли-Босна під Стамбулом. Побудувавши там невелику мечеть, він послідовно почав виконувати усі настанови ісламу, за що отримав від сусідів-мусульман засудливі погляди. Його навіть почали сприймати фанатиком. Це не дивно, адже неофіт повинен був довести свою рішучість у сповідуванні ісламу [9, с. 673].

Маючи особливий погляд на майбутнє Східної Європи, Мехмед Садик заходився реалізовувати фантастичну ідею всеслов'янського союзу під сюзеренітетом нащадка сербських королів - османського султана. Консервативна католицька польська еміграція відвернулась від колишнього свого представника. Козацтво стало головним засобом i головним гаслом Чайковського. В його уяві Гетьман України на чолі козацької кінноти 3 тріумфом вступав на старокиївські гори - і вказував булавою в бік Москви...

У 1855 p. у Стамбулі помер друг і вчитель Михайла Чайковського як письменника - Адам Міцкевич [3;80]. В нетрях кварталу Бейоглу, неподалік респектабельного Таксіму, провів останні тижні свого життя польський геній. Чорна плита на нижньому поверсі повідомляє, що тут помер і був початково похований Міцкевич. А приїхав до Стамбула він на запрошення Садик-паші. Вони разом мріяли про відродження Польщі в союзі з Україною-Руссю - i разом захоплювались кавалерійською звитягою османських козаків. Міцкевич і Садик-паша запропонували мільйонеру Якобу Ротшильду підтримати козацтво - i утворити в його складі окремий єврейський гусарський полк! Передчасна смерть Міцкевича обірвала ці плани, що як для свого часу виглядали наскільки екстравагантними, настільки ж провісницькими. Мине якихось півстоліття - і буде в Києві гетьман, і будуть по Вкраїні вільні козаки.

Як же при цьому оминути увагою козаків Чайковського. Полк перший був утворений у 1853 р. Він взяв участь у Кримській війні (діяв під Силістрою, Журжею, Бухарестом, Галацем та Тульчею), потім охороняв кордони з Грецією, дислокувався на Косовому полі, 
в Шумені, Едірне, Сливені тощо. Декілька сотень добровольців з козаків взяли участь у франко-прусській війні на боці Франції. Згідно з переліком турецьких підрозділів, козаки обороняли Плевну. За даними Івана Стойчева, підрозділ був знищений російською артилерією в бою під Горним Дубняком у жовтні 1877 р. У 1854 р. утворений другий полк - він став називатись драгунським. Його бойовий шлях тривав дещо довше - до 1886 р., коли драгуни були розформовані. Часто два підрозділи називають «слов'янськими легіонами» - в них служили поляки, болгари, росіяни, українці, серби. Були серед козаків i угорці, євреї, румуни, турки, черкеси. Справжній іноземний легіон в складі турецької армії. До 1871 р. офіційною мовою полків була слов'янська (в спогадах Чайковського вона зветься «малоросійською» - напевно так переклав 3 оригіналу штатний перекладач «Русской старины» більш властиву творам Михайла «українську мову»).

Останні десятиліття Чайковського були завершенням його життєвої «Одіссеї» він повернувся до своєї омріяної козацької України. Карколомний як для його сучасників оберт долі - польський повстанець, турецький генерал скористався амністією російського імператора і повернув до України.

Але що то був за час? Покровителька козацтва в Туреччині, Франція розгромлена Другим німецьким Рейхом. Австрія стала Австро-Угорщиною. Османська імперія загрожена слов'янським повстанським рухом відступила від ліберальної моделі модернізації і впритул наблизилася до перемоги турецького націоналізму. Польський визвольний рух став на шлях еволюційний. Імперія Російська переживала небачені реформи - селяни звільнені, перед судом усі рівні, автономія університетів, обмеження цензури, земства... У вільнодумців першої половини XIX століття голова йшла обертом від можливостей. А у відставного турецького генерала пробудилась туга за батьківщиною. Тож нічого дивного і непередбаченого.

Перші роки жив в Києві. На пенсію від султана, гонорари від друку книжок та подарунки від Олександра II. Спробував стати агентом впливу на польську громаду але був холодно проігнорований. Заходився писати спогади - пережив наново усе своє життя. Активно листувався з ветеранами османського козацтва. Придбав маєток в Чернігівській губернії і перебрався туди.

Знову став батьком - третя дружина грекиня Ірена Теосколо подарувала йому доньку. Старший син Адам вступив до російського війська - і вже після смерті батька дослужився до чину генерал-майора. Останнє повідомлення про нього - звіт Сімферопольського ВЧК про конфіскацію в 1919 р. у генерал-майора у відставці Чайковського фамільної шаблі, яка належала гетьману Брюховецькому. Молодший син Владислав зробив кар'єру при дворі султана - вершиною ії стало управління Ліваном у 1900-1907 pр. Дві доньки лишились спочатку на Балканах, згодом Кароліна перебралась до Трієсту, де й померла у 1901 р. Третя, найменша донька Анна отримувала освіту в Смольному інституті в Санкт-Петербурзі.

Респектабельна генеральська старість в пасторальних сіверських пейзажах наближала Чайковського до логічного завершення його життя.

Польський історик Францішек Равіта-Гавронський, користуючись чиїмось особистими свідченнями, докладно змалював останні години Садик-паші в будинку у Бірках поруч Остра. На Різдво до батьків прибула з Петербургу донька. На ранок мати повинна була везти іiі до залізничної станції на потяг. Михайло вимагав, аби Ірена взяла з собою слугу, та відмовлялась. Молодша на сорок років від чоловіка, вона мала коханця - і підстаркуватий Чайковський неодноразово сварився з нею через це. Шантажуючи дружину самогубством, Михайло пішов до своєї спальні. Усю ніч щось писав, а над ранок 3 п'ятизарядним револьвером рішуче увійшов до спальні 
дружини, де також ночувала й донька, сів на край ліжка й вистрелив собі у груди. До кімнати на звук пострілу увійшов російський офіцер, що ночував в одній із кімнат, i переніс вмираючого Садик-пашу до його кімнати. Поки покликали лікаря, Михайло стік кров’ю. Останні слова, що промовив «Усе набридло» [2, с. 98].

Поховали козака-шляхтича у сусідньому селі біля могили його бойового товариша та ад'ютанта Морозовича. Лишався мусульманином - тож православного відспівування не було - лише священник окропив небіжчика святою водою. Російські солдати, присутні при похованні, віддали відставному генералу останню шану.

Отже, у 1850 р. разом з багатьма біженцями та емігрантами Михайло Чайковський прийняв іслам та майже три десятиліття жив в Османській імперії. Його твори та листування дозволяють прослідкувати, як він сприйняв Ісламську імперію зсередини, як сприймав Ісламську релігію з точки зору новонаверненого мусульманина. Його випадок характерний i унікальний водночас, дозволяє по іншому поглянути на українськоісламські контакти в модерну добу.

Окремо слід виділити творчість Садик-паші, яка відкрила українському, польському, французькому, російському читачеві завісу ісламського світу. Образи мусульманина, турка, османа олюднюються, бар'єри непорозумінь та звинувачень розхитуються. Минуле відносин наповнюється прикладами співпраці. Майбутнє виглядає сповненим спільними проектами та звершеннями. Особиста доля Садикпаші свідчить про порозуміння, про толерування інакшості - про поширення цінностей модерного часу.

\section{Джерела та література:}

1. Chudzikowska Jadwiga Dziwne życie Sadyka Paszy o Michale Czajkowskim/Jadwiga Chudzikowska. - PIW, 1971.

2. Rawita-Gawronski Fr. Michal Czaykowski (Sadyk-pasza). Jego zycie, dzialalnosc wojskowa i literacka. / Fr. Rawita-Gawronski. - Zarys biograficzny. - Petersburg, 1901.

3. Segel Harold B. Mieckiewicz and the Juwish legion in memoirs of the Sadyk Pasha (Michal Czajkowski) / Segel Harold B. // The Polish review. - 1965. - Vol. 10. №3. - pp. 78-81.

4. Кирило-Мефодіївське товариство: в 3 т. - К.: Наук. думка, 1990. - Т. 1. - С. 295-301.

5. Короткий В.А. Міхал Чайковський і Володимир Антонович: "Українська школа" польської романтичної літератури і становлення українофільства./ В. А. Короткий. - Вінниця, 2015. $175 \mathrm{c}$.

6. Полторак В. М. У чотирикутнику європейських столиць: Михайло Чайковський та османські козаки в модернізації Південно-Східної Європи./ В. М. Полторак. - Одеса, 2018. $212 \mathrm{c}$.

7. Рибак М. Михайло Чайковський - Мегмет Садик Паша / М. Рибак // Альманах українського національного союзу. - Нью-Йорк, 1971. - С. 86-97.

8. Стойчев И.К. Казак-алая на Чайковски./ И. К. Стойчев. - София, 1944.

9. Чайковский М. Записки / М. Чайковский // Русская старина. - 1898. - Т.95. - Вип. 9. C. 673 .

\section{Referenses:}

1. Chudzikowska, Jadwiga, 1971. Dziwne życie Sadyka Paszy o Michale Czajkowskim. PIW. [in Polish]

2. Rawita-Gawronski Fr., 1901. Michal Czaykowski (Sadyk-pasza). Jego zycie, dzialalnosc wojskowa i literacka. Zarys biograficzny. Petersburg. [in Polish]

3. Segel Harold B., 1965. Mieckiewicz and the Juwish legion in memoirs of the Sadyk Pasha (Michal Czajkowski). The Polish review, 10(3), p. 78-81. [in Polish]

4. Kyrylo-Mefodiivske tovarystvo: U 3 t., 1990. Vol. 1. K.: Nauk. Dumka. p. 295-301. [in Ukranian] 
5. Korotkyi, V. A., 2015. Mikhal Chaikovskyi i Volodymyr Antonovych: "Ukrainska shkola" polskoi romantychnoi literatury i stanovlennia ukrainofilstva. Vinnytsia. 175 p. [in Ukranian]

6. Poltorak, V. M., 2018. U chotyrykutnyku yevropeiskykh stolyts: Mykhailo Chaikovskyi ta osmanski kozaky v modernizatsii Pivdenno-Skhidnoi Yevropy. Odesa. 212 p. [in Ukranian]

7. Rybak, M., 1971. Mykhailo Chaikovskyi - Mehmet Sadyk Pasha. Almanakh ukrainskoho natsionalnoho soiuzu. Niu-York. p. 86-97. [in Ukranian]

8. Stoichev, Y. K., 1944. Kazak-alaia na Chaikovsky. Sofyia. [in Bolgarian]

9. Chaikovskyi, M., 1898. Zapysky. Russkaia staryna, 95(9), p.673. [in Russian]

Отримано: 29.11.2020 p. 
ISSN 2519-2523 (print)

DOI: $10.18524 / 2519-2523.2020 .15 .218676$

Chornomors 'ka mynuvshyna. - 2020. - No.15

УДК 930.2:005.742(477.74-21)“'1838/1860”

\title{
STATISTICAL REPORTS OF THE ODESSA TRUSTEE COMMITTEE FOR PRISON AS A HISTORICAL SOURCE
}

\author{
Yevhenii Yurash \\ ORSID: https://orcid.org/0000-0001-8866-225X \\ Post-graduate student \\ of the Department of History of Ukraine \\ Odessa I. I. Mechnikov National University \\ 2, Dvoryanska Str., Odessa, 65082, Ukraine \\ sasha.urash2000@gmail.com
}

The article analyzes "statistical reports" as a historical source for studying the history of the functioning of the Trustee Committee for Prison. The Trustee Committee for Prison has been identified as an important form of social policy for the protection of certain groups. The main directions of activity of the Odessa Trustee Committee for Prison are investigated on the example of annual statistical reports. The economic component is described as one of the important forms of work of the Committee. It was found that the source of funding for the Committee was both public funds and charitable contributions. The dynamics of the number of the members of the Odessa Trustee Committee for Prison in the first period of its existence has been established, as the annual reports indicated the list of names of all them. Statistics on the number of prisoners were analyzed and the types of crimes committed were identified. The spiritual life of prisoners is studied as an aspect of moral correction of convicts.

Key words: reports, statistics, The Trustee Committee for Prison, Odessa

Свгеній Юраш

ORSID: https://orcid.org/0000-0001-8866-225X

Аспірант кафедри історії України, Одеський національний університет імені I. I. Мечникова Вул. Дворянська, 2, Одеса, 65082, Україна sasha.urash2000@gmail.com

\section{СТАТИСТИЧНІ ЗВІТИ ОДЕСЬКОГО ПІКЛУВАЛЬНОГО КОМІТЕТУ ПРО В'ЯЗНИЦІ ЯК ІСТОРИЧНЕ ДЖЕРЕЛО}

У статті проаналізовано статистичні звіти Піклувального комітету про в'язниці. Визначено, що Піклувальний комітет про в'язниці був одним із важливих форм реалізації сочіальної політики щзодо захисту окремих груп населення. На прикладі щорічних статистичних звітів досліджено основні напрямки діяльності Одеського Піклувального комітету про в'язниці. Охарактеризовано економічну складову як одну із важливих форм його роботи. Встановлено зміну чисельного складу Одеського Піклувального комітету про в'язниці в перші роки його існування. Досліджено роботу комітету в духовному вихованні арештантів.

Ключові слова: звіти, статистика, Піклувальний комітет про в'язниці, Одеса. 
Тюремна політика сучасних держав, у тому числі й України, пройшла значний історичний шлях становлення та розвитку, має цілу низку етапів, кожному із яких відповідає та чи інша карно-виконавча система 3 притаманними ій характерними рисами. XIX ст. $\epsilon$ найважливішим етапом розвитку регламентації соціальної політики щодо захисту окремої групи людей, які позбавлені волі та перебувають у місцях покарань. В Одесі, яка на той час входила до складу Російської імперії, ця політика розпочинає активно змінюватися з відкриттям Одеського Піклувального комітету про в'язниці у 1828 р., що було наслідком формування цілої мережі подібних закладів на території Російської імперії. Першим у Наддніпрянській Україні було створено комітет в Одесі, якому було надано права губернського Товариства. Він узяв на себе піклування над в’язницями Новоросійського краю i Бессарабської області. Організаційна діяльність Одеського Піклувального комітету про в'язниці координувалась відповідно до роботи Санкт-Петербурзького комітету, у тому числі на нього поширювалася і законодавча база. Тому Одеський комітет здійснював свою діяльність згідно з правилами, затвердженими імператором 19 липня 1819 р. Олександром I.

Для вивчення історичних процесів, зокрема діяльності різних благодійних організацій, велике значення мають статистичні джерела. Вони охоплюють досить різноманітні за змістом і формою інформацію, що виникла внаслідок масових описів, переписів, обліку та звітності. Саме аналіз статистичних звітів Піклувального комітету про в’язниці $є$ метою даної публікації. У фонді №361 «Одеський міський комітет опіки над в'язницями (Одесский попечительный комитет о тюрмах)» Державного архіву Одеської області зберігається достатньо статистичної інформації щодо висвітлення становлення та розвитку Одеського Піклувального комітету про в'язниці. Всього у фонді нараховується понад однієї тисячі справ з 1835 р. по 1900 р. Найбільшу групу статистичних джерел, що наявні в архіві, подали у формі звітів. При аналізі відповідних справ, увагу привертають саме звіти, що висвітлюють різні сфери діяльності та функціонування Піклувального комітету про в'язниці - керівний склад, соціально-економічна та організаційна складова тощо.

На початку звіту досить часто надавалась інформація про членів комітету, тим самим, не зважаючи на зосередження керівництва в руках офіційних осіб, зазначалось, що більшість його членів були приватними особами - великими підприємцями, священиками, громадськими діячами тощо. Будь-хто, хто робив систематичні благодійні внески, ставав членом комітету, а той хто робив одноразові пожертви - благодійником [6, с. 75].

В звіті за 1842 р. зазначалось «Віце-президентів - 3; Президент жіночого комітету -1 ; членів чоловічого комітету - 31; членів жіночого комітету - 7» [3, арк. 1]. Наприкінці звіту також зазвичай надавався поіменний список зазначених осіб, а також і відомості про членів комітету, які через певні обставини переставали бути в складі комітету, наприклад через смерть: «одеський купець Миколай Никитич Кумперов помер» [3, арк. 9]. Отже, щорічні звіти важливі для відтворення цілісної картини саме складу членів Комітету протягом його існування.

При підготовці до оформлення щорічного звіту Одеський Піклувальной комітет про в'язниці мав обов'язкову звітну документацію - «Відомості пожертвувань різними благодійниками», «Відомість про число людей, що утримуються» та «Рапорти».

Документація вищезгаданого типу надавала статистичні дані і висвітлювала переважно економічну складову діяльності комітету. Комітети на законодавчому 
рівні звільнялися від суворої звітності як благодійні організації, проте Правила, за якими визначалась робота Піклувальних комітетів про в'язниці, особливу увагу приділяли регламентації фінансової діяльності. Жорсткий контроль за витратами грошових коштів і прозорість звітності були характерними рисами Правил [6, с. 76]. Саме тому у щорічних звітах будь-які внески записувались до відповідних документів - «Відомостей».

На прикладі звітної інформації фінансова допомога з боку держави на перших етапах існування Комітету надавалась з чітким перерозподілом. Так, у звіті за 1838 р. зазначалось про «отримання від Одеської міської Думи на продовольчі товари - 9 тис. 34 руб., на опалення тюремного замку - 5 тис.11 руб., на освітлення - 851 руб.»...«було здійснено благодійних внесків членами комітету - 985 руб., загалом визначали суму внесків - 180 тис. 13 руб.» [1, арк. 9 зв.]. Крім того, в зазначеному фонді також наявні звіти не лише по Одеському комітету, а і загальний звіт усього Піклувального товариства про в'язниці по всім імперським комітетам, яких станом на 1851 р. нараховувалось 52 [5, арк. 117 зв.]. Відтак, статистичні відомості дають можливість відобразити дані не лише конкретно по Одеському комітету, а й загалом провести порівняльну характеристику. Так, у звіті за 1859 р. зазначено, що станом на 1 січня 1859 р. у Комітеті нараховувалось 18,970 руб., а протягом року скарбниця поповнилась державними коштами на суму в 34,410 руб. та 14,861 руб. благодійними внесками. I якщо для прикладу порівняти благодійні внески по іншим комітетам імперії, то саме благодійники Одеського комітету були на третьому місці, звичайно ж після Санкт-Петербурзького та Московського комітетів [4, арк. 129 зв.].

Пожертвування було однією 3 форм економічної складової функціонування Одеського Піклувального комітету. Відомості пожертвувань різними благодійниками можуть надати достатньо інформації щодо висвітлення відомостей про людину, яка робить внесок, зокрема, iї суспільний стан, дату та іiі розмір пожертвування, а при аналізі різних звітів за різні роки, то і періодичність подібних внесків. Так, у такій «Відомості» за 1840 р. зазначалося - «січня 29 - пожертвувано Генеральшою Сабантьєвою булок 25 фунтів ... лютого 17 - міщанкою Шумською булок 22 фунтів» [2, арк. 2]. Іноді пожертвування робились анонімно, але запис відповідний робився «квітня 12 Невідомою особою пожертвувано на свято десять рублів асигнаціями» [2, арк. 2], або ж «грудня 21 - невідомою особою риби 4 пуда» [2, арк. 3]. Окрім того можна й охарактеризувати форми пожертвувань - гроші або ж товари споживання тощо.

При аналізі звітів можна отримати інформацію і про кількість арештантів, які перебували у лікарні при тюремному замку, так, наприклад, «за звітом 1838 р. до лікарні протягом року звернулось 362 арештанти по чоловічому відділенні та 59 - по жіночому, з них за рік померло 6 арештантів чоловічого відділення» [1, арк. 12]. А вже через декілька років спостерігаємо наступну статистику «протягом року (1842 р.) в лікарню тюремного замку звернулись 377 арештантів чоловічого комітету і 101 арештантів жіночого» [2, арк. 3], також зазначалося про кількість арештантів, які одужали та окремо померли. Загалом зазначена інформація констатує саме характеристику умов проживання та певну стабільність щодо кількості звернень хворих до лікарні.

Зведені звіти Піклувального комітету надають інформацію і про духовну складову життя арештантів, знову ж таки як загалом, так і показники по окремих комітетах. Дійсно, комітет по-особливому спостерігав за духовним життям ув'язнених та мав направляти їх «на шлях істини» і звітувати про їхню релігійну приналежність. Так, наприклад, у звіті за 1851 р. зазначалося, що по Одеському комітету до православної 
церкви приєдналось шысть арештантів [5, арк. 120 зв.]. Також у звітах надавалась статистика щодо загальної кількості ув'язнених за конкретними злочинами та загальна кількість арештантів, які утримувались у в’язницях імперії. Так, станом на $1851 \mathrm{p}$. загальна кількість арештантів складала 41 тис. 416 осіб [5, арк. 125], а вже у 1859 р. - 138 тис. 343 особи. Згідно 3 зазначеними даними найбільше було злочинців скояли крадіжку, шахрайство, дрібні злочини тощо.

Отже, статистичні звіти є цінним джерелом для вивчення історії становлення та розвитку соціальної політики щодо захисту окремих груп населення як в Російській імперії загалом, так і в Одеському Піклувальному комітету про в'язниці. Кількісні показники дають можливість не лише за конкретними показниками висвітлити економічну, соціальну, структурну складові функціонування комітету та їхні зміни. Відповідно при аналізі кількісних даних постає можливість комплексного дослідження рівня злочинності в регіоні, на конкретних прикладах дослідити умови відбування покарань і можливість зміни цих умов.

\section{Джерела та література:}

1. Державний архів Одеської області. - Ф.361. - Оп.1. - Спр. 8. - 34 арк. (Звіт піклувального комітету за 1839 рік і про дії свої).

2. Державний архів Одеської області. - Ф.361. - Оп.1. - Спр. 21а. - 26 арк. (Відомості до річного звіту за 1840 рік).

3. Державний архів Одеської області. - Ф.361. - Оп.1. - Спр. 39. - 10 арк. (Річний звіт піклувального про в'язниці комітету).

4. Державний архів Одеської області. - Ф.361. - Оп.1. - Спр. 68. - 156 арк. (Про звіт Комітету за 1846 рік і про утримання арештантів)

5. Державний архів Одеської області. - Ф.361. - Оп.1. - Спр. 142. - 125 арк. (Про річні звіти про грошові суми і діях Комітету за 1851 рік).

6. Пальченкова В. М. Трансформація правової регламентації діяльності Товариства піклувального про тюрми (1819-1919) / В. М. Пальченкова // Науковий вісник Дніпропетровського державного університету внутрішніх справ. - 2012. - № 4. - С.74-76.

\section{References:}

1. Derzhavnyy arkhiv Odes'koyi oblasti (The State Archives of the Odessa region (Ukraine)). F.361. Op.1. Spr. 8. 34 ark. (Zvit pikluvalnoho komitetu za 1839 rik i pro dii svoi) [in Russian]

2. Derzhavnyy arkhiv Odes'koyi oblasti (The State Archives of the Odessa region (Ukraine)). F.361. Op.1. Spr. 21a. 26 ark. (Vidomosti do richnoho zvitu za 1840 rik) [in Russian]

3. Derzhavnyy arkhiv Odes'koyi oblasti (The State Archives of the Odessa region (Ukraine)). F.361 (Odeskyi miskyi komitet opiky nad viaznytsiamy). Op.1. Spr. 39. 10 ark. (Richnyi zvit pikluvalnoho pro viaznytsi komitetu) [in Russian]

4. Derzhavnyy arkhiv Odes'koyi oblasti (The State Archives of the Odessa region (Ukraine)). F.361. Op.1. Spr. 142. 125 ark. (Pro zvit Komitetu za 1846 rik i pro utrymannia areshtantiv) [in Russian]

5. Derzhavnyy arkhiv Odes'koyi oblasti (The State Archives of the Odessa region (Ukraine)). F.361. Op.1. Spr. 68. 156 ark. (Pro richni zvity pro hroshovi sumy i diiakh Komitetu za 1951 rik) [in Russian]

6. Palchenkova, V., 2012. Transformatsiia pravovoi rehlamentatsii diialnosti Tovarystva pikluvalnoho pro tiurmy (1819-1919). Naukovyi visnyk Dnipropetrovskoho derzhavnoho universytetu vnutrishnikh sprav, 4, p.74-76. [in Ukrainian]

Отримано: 03.12.2020 p. 
ISSN 2519-2523 (print)

Chornomors 'ka mynuvshyna. - 2020. - No.15

DOI: $10.18524 / 2519-2523.2020 .15 .218677$

УДК 94:929Сокальський (477.74-21)“1869/1871”

\title{
PETRO SOKALSKYI AS A REPRESENTATIVE OF THE IMPERIAL SOCIETY OF AGRICULTURE OF SOUTHERN RUSSIA (1869-1871)
}

\author{
Kseniia Sorokina \\ ORCID: https://orcid.org/0000-0002-4130-038X \\ Post-graduate student of the Department of History and Etnography of Ukraine \\ Odessa National Polytechnic University \\ 1, T. Shevchenko Av., Odessa, 65044, Ukraine \\ oksanawerty@gmail.com
}

The presented study is an attempt to comprehensively analyze the share of the participation of Ukrainian composer and publicist Sokalskyi Petro Petrovych (1832-1887) in the Imperial Society of Agriculture of Southern Russia during 1869-1871. Based on the materials of volumes of «Notes of the Imperial Society of Agriculture of Southern Russia» and historical reviews of the activities of the society, it was found out that during this period Petro Petrovych held in society two positions at once - the secretary of the society and the editor of its printed edition - the above-mentioned "Notes of the Imperial Society of Agriculture of Southern Russia».

In this regard, the author of the article not only provides an overview of the work of Petro Sokalskyi in the numerous branch commissions of the society, among which - the commission for the development of sheep farming in the south of the empire; the commission for the development of wood farming; the chemical commission at the winemaking exhibition; etc.; but also tries to compile the bibliography of Petro Sokalskyi articles in the printed edition of the society. The compiled list of Petro Petrovych's publications on agricultural topics is presented as an addition to the article. These articles were the review of the problems of agriculture in the south of the empire in different years; the discussion of measures of encouraging the sheep farming and the wood farming in the region; the description of the results of the exhibition of viticulture and winemaking; and so on.

It is also interesting to note that except Petro Petrovych, among the members of the society there were also his older brothers - scientist and publicist Ivan Sokalskyi and publicist Mykola Sokalskyi. This fact and the multifaceted activity of Petro Petrovych in the Imperial Society of Agriculture of Southern Russia opens the horizons for further careful study of the topic and for broader historiographical analysis, because there are a number of unresolved thematical issues.

Keywords: Petro Sokalskyi; Imperial Society of Agriculture of Southern Russia; "The Notes of the Imperial Society of Agriculture of Southern Russia»; the secretary of Society; the editor of the Society's printed edition; 1869-1871.

Ксенія Сорокіна

ORCID: https://orcid.org/0000-0002-4130-038X Аспірантка кафедри історії та етнографії України Одеського національного політехнічного університету Пр. Т. Шевченка, 1, Одеса, 65044, Україна oksanawerty@gmail.com

\section{ПЕТРО СОКАЛЬСЬКИЙ ЯК ДІЯЧ ІМПЕРАТОРСЬКОГО ТОВАРИСТВА СІЛЬСЬКОГО ГОСПОДАРСТВА ПІВДЕННОЇ РОСІЇ (1869-1871)}

Презентоване дослідження являє собою спробу комплексного аналізу долі участі українського композитора та публіциста Сокальського Петра Петровича (1832-1887) $в$ 
лавах Імператорського товариства сільського господарства Південної Росї̈ протягом 18691871 рр. Зокрема, з'ясовано, шио протягом означеного періоду Петро Петрович обіймав у Товаристві одразу дві посади - секретаря товариства та редактора його друкованого органу - «Записок Императорского Общества сельского хозяйства южной России». В зв 'язку з иим, у статті не лише надано огляд роботи Петра Сокальського на базі численних галузевих комісій товариства, але й здійснено бібліографування публіцистичної спадщини автора в зазначеному часописі Товариства. Складений перелік публікачій Петра Петровича на сільськогосподарську тематику винесено у якості додатку до статті.

Ключові слова: Петро Сокальський; Імператорське товариство сільського господарства Південної Росї; «Записки Императорского общества сельского хозяйства южной России».

Постать представника старовинного українського козацького роду - композитора та публіциста Петра Петровича Сокальського (1832 - 1887), діяльність якого розгорнулася в Одесі в другій половині ХІХ ст. свого часу була відомою та глибоко шанованою у національному культурному та громадському середовищі. Станом на сьогодні у вітчизняній історіографії існує низка історичних нарисів, які 3 різних методологічних позицій оцінюють його здобутки. Проте, в дослідженні життєпису та систематизації інтелектуального доробку Петра Сокальського i досі залишається низка не опрацьованих аспектів, 3-поміж яких на перший план можна винести діяльність на базі Імператорського товариства сільського господарства Південної Росії (далі ІТСГ) протягом 1869-1871 pp. Дана стаття фактично являє собою одну із

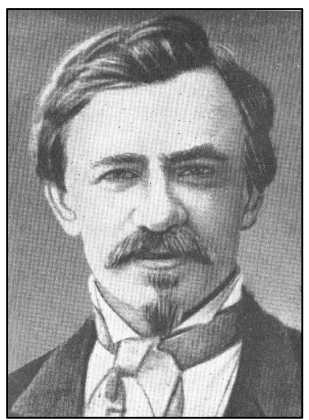

Петро Петрович в 1870-mi pp. перших спроб комплексного аналізу долі участі Петра Петровича в лавах ITCГ, а також бібліографування публіцистичної спадщини автора в «Записках Императорского Общества сельского хозяйства южной России».

Згідно 3 «Историческим обзором пятидесятилетия деятельности Императорского Общества сельского хозяйства южной России с 1828 по 1878 год.», складеного секретарем товариства Боровським М.П., утворене 1828 р. за ініціативи князя Воронцова М.С., ІТСГ 3 центром в Одесі являло собою одне із найстаріших імперських сільськогосподарських товариств. Метою його діяльності були популяризація і поширення знань з усіх галузей тогочасного сільського господарства: тваринництва, лісорозведення, садівництва, виноградарства, тощо. Товариство проводило чисельні дослідження, організовувало сільськогосподарські конкурси та виставки, преміювало найкращих селекціонерів та господарів. Велике значення для акумуляції та обміну агрономічними знаннями на півдні України відігравав також друкований орган ІТСГ - «Записки Императорского общества сельского хозяйства южной России».

Перебування Петра Сокальського у ІТСГ розпочалося 21 листопада 1868 р. [9, c. 105; 7, с. 44], а вже 18 січня 1869 р. його кандидатуру було одностайно обрано на посаду секретаря Товариства $[17$, с. 3] (обіймав до передачі повноважень вченому, педагогу Армфельду О.О. [5, с. 6] 16 жовтня 1871 р. [7, с. 25]) та відповідно редактора його звітної документації, яка виходила в світ у вигляді томів «Записок» [7, с. 253].

Цікаво, що під 1862 р. в «Историческом обзоре пятидесятилетия деятельности Императорского Общества сельского хозяйства южной России с 1828 по 1878 год» згадано комісію з питань дійсного стану одеських хуторів під головуванням віце- 
президента Андрієвського Е.С., до складу якої в тому числі увійшов дехто «К.П. Сокальський» [7, с. 224]. Мова в даному випадку йшла імовірно про одного зі старших братів Петра Сокальського, також, членів ІТСГ - науковця, публіциста Івана Петровича (вступив до товариства 25 листопада 1852 р. [8, с. 102; 7, с. 43]) або головного редактора «Одесского вестника» Миколи Петровича (в ІТСГ від 18 листопада 1859 р.) [8, с. 103; 7, с. 43], 3 помилковими ініціалами «К.П.».

Офіційні ж дані про початок роботи Петра Петровича було висвітлено на шпальтах «Одесского вестника» його попередником агрономом, професором Імператорського Новоросійського Університету Палімпсєстовим І.У., котрий не міг продовжувати членство у лавах ІТСГ через погіршення стану здоров'я [6]. Зауважимо, що редакція газети, очолювана в означений хронологічний період членом ITCГ, старшим братом Петра Петровича - Миколою Сокальським, як зазначалося вище, також зчаста повідомляла про вихід у світ свіжих матеріалів засідань сільськогосподарських комісій Товариства [1].

Нижче спробуємо узагальнити діяльність Петра Сокальського на базі ITCГ відповідно до років його членства. В засіданні від 22 листопада 1867 р. Товариство дійшло висновку, що вовна має обкладатися протекціоністським митним тарифом, якщо не на тривалий час, то хоча б до моменту, поки південь імперії не буде зв'язано iз внутрішніми та південно-західними фабричними губерніями за допомогою залізничних доріг. Виходячи 3 даної ініціативи постало клопотання перед міністром фінансів, пояснення на яке надав 2 січня 1868 р. Новоросійський генерал-губернатор, котрий у своїй промові наголосив про передачу питання на розгляд Височайше затвердженої комісії для перегляду європейського митного тарифу, проте Товариство на цьому не зупинилося.

Зважаючи на труднощі, що продовжували виникати у розвитку мериносового вівчарства на півдні імперії, того ж 1868 р. було укладено чергове клопотання за посередництва головного начальника Новоросійського краю перед вищим урядом на користь встановлення протекціоністських заходів щодо вищеозначеного типу тваринництва.

Враховуючи подання, Новоросійський генерал-губернатор у звіті з управління краєм за 1868 р. вказав на занепад вівчарства, начебто через збільшення цін на землі, зміни попиту щодо якості товарів та посилення привозу в Свропу іноземної, зокрема, австралійської вовни [7, с. 175-176]. Задля виконання Найвищої резолюції, що надійшла після зазначеного звіту, в Одесі було створено комісію з членів міністерств фінансів та державних маєтностей, а також ІТСГ, від якого у якості одного з експертів був Петро Петрович [10-12].

У 1869 р. на Петра Петровича було покладено відповідальність роботи в комісії з розрахунку витрат товариства за рік [17, с. 3], діяльність якої з часом подовжили на 1870 р. [4].

Згодом він став учасником суперечки, що виникла між ІТСГ, яке розміщувалося в приміщенні по вул. Дерибасівській та деяким п. Базилі, будинок котрого розташовувався по сусідству. Зважаючи на урахування потреб громадян, товариство мало отримати дозвіл останнього задля перебудови власної будівлі. Схвальна відповідь була обіцяна за те, аби ремонтні роботи були виконані безпосередньо секретарем ІТСГ Петром Сокальським [3, с. 196-197].

Наприкінці року термін виконання Петром Петровичем обов'язків секретаря було подовжено на 1870 р. [3, с. 731], на цьому ж засіданні він виступив із пропозицією роздати членам Товариства для дослідів зразки насіння кукурудзи та пшениці, отримані із Лондона [3, с. 733]. 
У 1870 р. була влаштована виставка, що мала за мету показати виноробство півдня Російської імперії та Кавказу. Засіб експертизи значно відрізнявся від раніше прийнятого і вино, що було на виставці, піддано докладному хімічному дослідженню, що доповнило експертизу смакових показників і дозволило скласти більш повну картину виноробства.

Член експертної комісії хімік та агроном Абашев Д. М. звернув увагу на те, що «експертиза вин за смаком, хоча і дозволяє відрізнити кращі з них, але не дає позитивної вказівки щуодо причин, з яких одні вина краще інших, тільки хімічний аналіз може показати, чим кращі вина відрізняються від гірших і середніх $і$ чим наші вина відрізняються від закордонних, вказавши, які особливості складу надають винам ті якості, які цүінуються експертами». Міністерство поставилося цілком співчутливо до цієї думки і асигнувало на виробництво аналізів 1000 руб. Організація хімічних досліджень напоїв була доручена спеціальній комісії хіміків, що складалася із вже названого Абашева Д. М., професора технології в Університеті Св. Володимира м. Київ Бунге М. А. (в тексті протоколів помилково названий Бунге I. А., якщо, звичайно не існував його майже повний тезка прим.авт.), хіміка-винороба при Імператорському Нікітському саді (Крим) Саломона О. С. та Петра Сокальського [4, с. 5, 21, 28], який мав розподіляти вина за преміями [4, с. 8$]$.

Аналізи проводилися одноманітними методами, відповідно до заздалегідь встановленого плану. Це були перші для того часу докладні аналізи вин, усього було піддано дослідженню 65 сортів вин, отримані дані послужили для вельми цікавих порівнянь імперських вин як між собою, так і з іноземними [7, с. 138-140]. Детальні подробиці досліджень було занотовано у звітах про виставку, складених Петром Сокальським і Саломоном О. Є. [16].

Таким чином, виставка 1870 р. подала повну картину стану імперського виноробства, вказала на відмінності, переваги і недоліки вин, намітивши шляхи, якими повинна слідувати виноробна практика для досягнення кращих результатів, бесіди ж дали можливість виноробам обмінятися думками та спостереженнями, ознайомитися 3 новими прийомами виноробства, обговорити свої потреби і вказати на заходи, що полегшують їх [13-14].

Природним доповненням до цього стала пропозиція секретаря Петра Сокальського аби Товариство сприяло поширенню збуту імперських вин. Як перший крок у цьому напрямку Сокальський вказав на користь дослідів 3 дальнього перевезення вин морем, 3 метою випробування - чи витримають вони подібне транспортування [15].

У зв’язку з тим, що в зазначений час відбувались рейси через Суецький канал у Бомбей, Калькуту та інші порти Азії, виникла ідея зробити при цьому досліди транспортування вин і разом $з$ тим - ознайомлення з ними споживачів на сході. ІТСГ, хоча й визнавало більш необхідним ознайомити 3 винами насамперед внутрішній ринок, тим не менш знайшло цікавим провести подібні випробування. Товариство пароплавства і торгівлі співчутливо поставилось до пропозиції, а отже вина були відправлені в Бомбей, вони двічі перетнули екватор, не піддаючись псуванню, чим довели власну якість [7, с. 144-145].

На одному з чергових засідань 1870 р. Петро Петрович виголосив промову щодо результатів виставки плодівництва та запропонував на майбутнє експонувати не лише свіжі овочі та фрукти, а й вироби з них, зокрема, варення, джеми та желе [4, с. 98]. Під час наступних зібрань його було відзначено за трирічну активну діяльність у лавах ІТСГ $[4$, c. 788$]$. 
Петро Петрович також був задіяний в одній із довготривалих акцій Товариства. 1846 р. віце-президент ІТСГ подав записку «про необхідність лісів у степах $i$ про великі наслідки їх розведення, як то: надання вологості сухому трунту, утворення водних джерел та природних перешкод посушливим вітрам, наявність природного палива, матеріали для будівель і нарешті зміна самого клімату».

Віце-президент запропонував клопотати про дозвіл заснувати для всіх станів «змагання в розведенні лісових плантацій», 3 нагородами із сум, асигнованих для заохочення садівництва та лісництва. Товариство схвалило прохання і комісія виробила нові правила, затверджені в 1847 р. Конкурс тривав два роки і закінчився в 1850 р., але претендентів не виявилося, через що його дію не відновили.

Через десять років, у 1860 р. ІТСГ, бажаючи відновити конкурс з розведення дерев запропонувало п. Струкову розглянути існуючі правила і дати свій висновок. Була призначена комісія для складання нових правил конкурсу, які й були затверджені 22 січня 1863 р.

У 1863 р. конкурс було оголошено, а 1864 р. з'явилися перші кандидати на участь. 1871 р. терміни розгляду заявок закінчилися і Товариство знову затвердило комісію для перегляду правил та подання міркувань про те, якими заходами могло б бути успішно заохочено деревництво в краї. До їі складу було включено також Петра Петровича [4, с.273]. У своїй доповіді структура розглянула, по-перше, питання про значення заохочувальних заходів, по-друге - про збереження природних лісів і потретє - про обов'язкове дереворозведення в краї [7, с. 113-116]. Грунтовна доповідь комісії міститься в «Записках» за 1871 р. [2].

Отже, аналіз досліджень української історіографії щодо діяльності Петра Сокальського у лавах Імператорського товариства сільського господарства Південної Росії виявив фактичну відсутність наукових нарисів 3 цього питання і надав можливість 3'ясувати історіографічний інтерес до окресленого аспекту громадської та наукової праці даної постаті. У свою чергу, опрацювання тематичної джерельної бази, що складається головним чином із томів «Записок Императорского общества сельского хозяйства южной России», а також історичних оглядів діяльності Товариства, дозволило викристалізувати, зокрема, важливу роль Петра Петровича у функціонуванні галузевих сільськогосподарських комісій Товариства та ІТСГ в цілому. В ході дослідження було 3'ясовано, що протягом 1869-1871 pp. Петро Сокальський не тільки суміщав при Товаристві дві посади - секретаря та редактора періодичного друкованого видання ІТСГ, що покладало на нього відповідальність у веденні звітної документації, але й виявив себе, як активний дописувач на сільськогосподарську тематику. Загалом, багатогранність активності Петра Петровича при ІТСГ відкриває горизонти для подальшого ретельного вивчення тематики та більш широкого історіографічного аналізу, оскільки залишається низка нез'ясованих дискусійних питань.

\section{Бібліографія публікацій Петра Сокальського в «Записках Императорского Общества сельского хозяйства Южной России» за 1869-1872 рр.}

(здійснена за виданням Бориневич А. С. Систематический указатель статей, заметок, протоколов, отчетов и проч. помещенных в «Листках» и «Записках» Императорского Общества Сельского Хозяйства Южной России с 1830 по 1894 / Антон Самойлович Бориневич. Одесса: «Славянская» тип. Н. Христогелос, 1895. 130 с.)

\section{9}

1. Редактор Записок Императорского Общества сельского хозяйства Южной России Петр Петрович Сокальский Взгляд на современные задачи сельского хозяйства 
Южной России (вместо предисловия от новой редакции Записок) // Записки Императорского Общества сельского хозяйства Южной России (далі ЗИОСХЮР). 1869. С. 15-29.

2. [П.С.] Переносные колодцы // ЗИОСХЮР. 1869. С. 76-81.

3. [П.С.] О хлебных червях и жучках // ЗИОСХЮР. 1869. С. 215-221.

4. [П.С.] Наглядные признаки для определения погоды ближайших дней // ЗИОСХЮР. 1869. С. 237-243.

5. [П.С.] Исторический обзор. Влияние различных тарифов на шерстяное дело в Северо-Американском союзе дней // ЗИОСХЮР. 1869. С. 573-578.

6. [П.С.] Сельско-хозяйственное обозрение // ЗИОСХЮР. 1869. С. 774-783.

7. [П.С.] От редакции // ЗИОСХЮР. 1869. С. 790-794.

1870

1. [П. Сок.] Труды комиссии для обсуждения мер к поддержанию овцеводства в Новороссийском крае. Заседание 28-го ноября 1869 года // ЗИОСХЮР. 1870. С. 179-185.

2. [П. Сок.] Труды комиссии для обсуждения мер к поддержанию овцеводства в Новороссийском крае. Заседание 1-го декабря 1869 года // ЗИОСХЮР. 1870. С. 186-193.

3. [П. Сок.] Труды комиссии для обсуждения мер к поддержанию овцеводства в Новороссийском крае. Заседание 5-го декабря 1869 года // ЗИОСХЮР. 1870. С. 194-213.

4. П.С. О жатвенных машинах (По поводу испытания жатки Джонстона близ Одессы, 2 июля 1870 года) // ЗИОСХЮР. 1870. С. 523-536.

5. [П.С.] Несколько заключений по шерстяному вопросу // ЗИОСХЮР. 1870. С. 577-610.

6. [П.С.] Сельскохозяйственное обозрение // ЗИОСХЮР. 1870. С. 654-680.

7. [П. Сок.] Сельскохозяйственное обозрение // ЗИОСХЮР. 1870. С. 744-765.

8. [П. Сок.] Сельскохозяйственное обозрение // ЗИОСХЮР. 1870. С. 823-842.

9. [П.С.] Сельскохозяйственное обозрение // ЗИОСХЮР. 1870. С. 906-924.

1871

1. [П.С.] Сельскохозяйственное обозрение // ЗИОСХЮР. 1871. С. 76-88.

2. [П.С.] Новейшие наблюдения в области рыбоводства // ЗИОСХЮР. 1871. С. 142-152.

3. Доклад секретаря П. Сокальского по вопросу о поощрении древоразведения в Новороссийском крае // ЗИОСХЮР. 1871. С. 267-273.

4. Сокальский П. Беседы о виноделии во время выставки вониградарства и виноделия в Одессе, в октябре 1870 года // ЗИОСХЮР. 1871. С. 355-378.

5. Сокальский П. Беседы о виноделии во время выставки вониградарства и виноделия в Одессе, в октябре 1870 года (беседа вторая) // ЗИОСХЮР. 1871. С. 561-570.

6. Сокальский П. Сельскохозяйственное обозрение. Статистический и торговый очерк главнейших рынков для сбыта виноградного вина в Европе // ЗИОСХЮР. 1871. С. 637-669.

\section{2}

1. Сокальский П. П. Отчет о выставке виноградарства и виноделия бывшей в г. Одессе при Императорском Обществе сельского хозяйства южной России с 8-го октября по 8-е ноября 1870 г. // ЗИОСХЮР. 1872. Т. 1. № 3. С. 29-115.

\section{Джерела та література:}

1. Библиографические новости [...] // Одесский вестник. - 1871. - 10 октября.

2. Доклад секретаря П. Сокальского по вопросу о поощрении древоразведения в Новороссийском крае // Записки Императорского Общества сельского хозяйства Южной России (далі ЗИОСХЮР). - 1871. - С. 267-273. 
3. Записки Императорского Общества сельского хозяйства Южной России, издаваемые под редакцией Секретаря Общества Петра Петровича Сокальского. - Одесса: в типографии Л. Нитче, 1869.

4. Записки Императорского Общества сельского хозяйства Южной России, издаваемые под редакцией Секретаря Общества Петра Петровича Сокальского. - Одесса: в типографии Л. Нитче, 1871.

5. Записки Императорского Общества сельского хозяйства Южной России, издаваемые под редакцией Секретаря Общества А.А. Армфельда. - Одесса: типография Ульриха и Шульце, 1872.

6. Палимпсестов И. От бывшего секретаря Императорского Общества сельского хозяйства южной России и редактора его записок / И. Палимпсестов // Одесский вестник. - 1869. 15 февраля.

7. Исторический обзор пятидесятилетия деятельности Императорского Общества сельского хозяйства южной России с 1828 по 1878 год / составлен секретарем Общества М.П. Боровским. -Одесса: Тип. П. Францова, 1878. - 278 с.

8. Новороссийский адрес календарь. V. Управление отдельных ведомств // Новороссийский календарь на 1865 год, издаваемый от Ришельевского Лицея. -Одесса: в типографии Л. Нитче, 1864. - С. 49-111.

9. Новороссийский адрес календарь. V. Управление отдельных ведомств. // Новороссийский календарь на 1867 год, издаваемый от Ришельевского Лицея. - Одесса: в типографии Л. Нитче, 1866. - C. 49-158.

10. [П. Сок.] Труды комиссии для обсуждения мер к поддержанию овцеводства в Новороссийском крае. Заседание 28-го ноября 1869 года // ЗИОСХЮР. - 1870. - С. 179-185.

11. [П. Сок.] Труды комиссии для обсуждения мер к поддержанию овцеводства в Новороссийском крае. Заседание 1-го декабря 1869 года // ЗИОСХЮР. - 1870. - С. 186-193.

12. [П. Сок.] Труды комиссии для обсуждения мер к поддержанию овцеводства в Новороссийском крае. Заседание 5-го декабря 1869 года // ЗИОСХЮР. - 1870. - С. 194-213.

13. Сокальский П. Беседы о виноделии во время выставки виноградарства и виноделия в Одессе, в октябре 1870 года / П. Сокальский // ЗИОСХЮР. - 1871. - С. 355-378.

14. Сокальский П. Беседы о виноделии во время выставки виноградарства и виноделия в Одессе, в октябре 1870 года (беседа вторая) / П. Сокальский // ЗИОСХЮР. - 1871. - С. 561570.

15. Сокальский П. Сельскохозяйственное обозрение. Статистический и торговый очерк главнейших рынков для сбыта виноградного вина в Европе / П. Сокальский // ЗИОСХЮР. - 1871. - С. 637-669.

16. Сокальский П. Отчет о выставке виноградарства и виноделия бывшей в г. Одессе при Императорском Обществе сельского хозяйства Южной России с 8-го октября по 8-е ноября 1870 г. / П. Сокальский // ЗИОСХЮР. - 1872. - Т. 1. № 3. - С. 29-115.

17. Протокол заседания Императорского Общества сельского хозяйства Южной России, 18 января 1869 г. // ЗИОСХЮР. - 1869. - С. 2-4.

\section{References:}

1. Bibliograficheskiye novosti [...], 1871. Odesskyi vestnik, 10 oktyabrya. [in Russian].

2. Doklad sekretarya P. Sokalskogo po voprosu o pooshchrenii drevorazvedeniya v Novorossiyskom kraye, 1871. Zapiski Imperatorskogo Obshchestva selskogo khozyaystva Yuzhnoy Rossii, p. 267-273. [in Russian].

3. Zapiski Imperatorskogo Obshchestva selskogo khozyaystva Yuzhnoy Rossii, izdavayemyye pod redaktsiyey Sekretarya Obshchestva Petra Petrovicha Sokalskogo, 1869. Odessa: v tipografii L. Nitche. [in Russian].

4. Zapiski Imperatorskogo Obshchestva selskogo khozyaystva yuzhnoy Rossii, izdavayemyye pod redaktsiyey Sekretarya Obshchestva Petra Petrovicha Sokalskogo, 1871. Odessa: v tipografii L. Nitche. [in Russian]. 
5. Zapiski Imperatorskogo Obshchestva selskogo khozyaystva Yuzhnoy Rossii, izdavayemyye pod redaktsiyey Sekretarya Obshchestva A.A. Armfelda, 1872. Odessa: tipografiya Ulrikha i Shultse. [in Russian].

6. Palimpsestov, I., 1869. Ot byvshego sekretarja Imperatorskogo Obshhestva sel'skogo hozjajstva juzhnoj Rossii i redaktora ego zapisok . Odesskij vestnik, 15 fevralja. [in Russian].

7. Borovskim, M. P. comp., 1878. Istoricheskiy obzor pyatidesyatiletiya deyatelnosti Imperatorskogo Obshchestva selskogo khozyaystva yuzhnoy Rossii s 1828 po 1878 god. Odessa: Tip. P. Frantsova, 278 p. [in Russian].

8. Novorossiyskiy adres kalendar. V. Upravleniye otdelnykh vedomstv, 1864. Novorossiyskiy kalendar na 1865 god. izdavayemyy ot Rishelyevskogo Litseya. Odessa: v tipografii L. Nitche, p. 49-111. [in Russian].

9. Novorossiyskiy adres kalendar. V. Upravleniye otdelnykh vedomstv, 1866. Novorossiyskiy kalendar na 1867 god. izdavayemyy ot Rishelyevskogo Litseya. Odessa: v tipografii L. Nitche, p. 49-158.

10. [P. Sok], 1870. Trudy komissii dlya obsuzhdeniya mer $\mathrm{k}$ podderzhaniyu ovtsevodstva $\mathrm{v}$ Novorossiyskom kraye. Zasedaniye 28-go noyabrya 1869 goda. Zapiski Imperatorskogo Obshchestva selskogo khozyaystva Yuzhnoy Rossii, p. 179-185. [in Russian].

11. [P. Sok], 1870. Trudy komissii dlya obsuzhdeniya mer $\mathrm{k}$ podderzhaniyu ovtsevodstva $\mathrm{v}$ Novorossiyskom kraye. Zasedaniye 1-go dekabrya 1869 goda. Zapiski Imperatorskogo Obshchestva selskogo khozyaystva Yuzhnoy Rossii, p. 186-193. [in Russian].

12. Palimpsestov, I., 1869. Ot byvshego sekretarya Imperatorskogo Obshchestva selskogo khozyaystva yuzhnoy Rossii i redaktora ego zapisok. Odesskyi vestnik, 15 fevralya. [in Russian].

13. [P. Sok], 1870. Trudy komissii dlya obsuzhdeniya mer $\mathrm{k}$ podderzhaniyu ovtsevodstva $\mathrm{v}$ Novorossiyskom kraye. Zasedaniye 5-go dekabrya 1869 goda. Zapiski Imperatorskogo Obshchestva selskogo khozyaystva Yuzhnoy Rossii, p. 194-213. [in Russian].

14. Sokalskiy, P., 1871. Besedy o vinodelii vo vremya vystavki vinogradarstva i vinodeliya v Odesse. v oktyabre 1870 goda. Zapiski Imperatorskogo Obshchestva selskogo khozyaystva Yuzhnoy Rossii, p. 355378. [in Russian].

15. Sokalskiy, P., 1871. Besedy o vinodelii vo vremya vystavki vinogradarstva $\mathrm{i}$ vinodeliya $\mathrm{v}$ Odesse. v oktyabre 1870 goda (beseda vtoraya). Zapiski Imperatorskogo Obshchestva selskogo khozyaystva Yuzhnoy Rossii, p. 561-570. [in Russian].

16. Sokalskiy, P., 1871. Selskokhozyaystvennoye obozreniye. Statisticheskiy i torgovyy ocherk glavneyshikh rynkov dlya sbyta vinogradnogo vina v Evrope. Zapiski Imperatorskogo Obshchestva selskogo khozyaystva Yuzhnoy Rossii, p. 637- 669. [in Russian].

17. Sokalskiy, P., 1872. Otchet o vystavke vinogradarstva i vinodeliya byvshey v g. Odesse pri Imperatorskom Obshchestve selskogo khozyaystva yuzhnoy Rossii s 8-go oktyabrya po 8-e noyabrya 1870 g. Zapiski Imperatorskogo Obshchestva selskogo khozyaystva Yuzhnoy Rossii, 1( 3), p. 29-115. [in Russian].

18. Protokol zasedaniya Imperatorskogo Obshchestva selskogo khozyaystva yuzhnoy Rossii. 18 yanvarya 1869 g., 1869. Zapiski Imperatorskogo Obshchestva selskogo khozyaystva Yuzhnoy Rossii, p. 2-4. [in Russian].

Отримано: 04.12.2020 p. 
ISSN 2519-2523 (print)

DOI: $10.18524 / 2519-2523.2020 .15 .218678$

УДК 94:070:377.8(477.74-21) “1827/1894”

\title{
NEWSPAPER «ODESSA HERALD» (1827-1894) AS A HISTORICAL SOURCE ON THE HISTORY OF THE ODESSA INSTITUTE OF NOBLE MAIDEN
}

\author{
Anna Korobchuk \\ ORCID: https://orcid.org/0000-0001-9125-7036 \\ Post-graduate student at the Department of Ukrainian History \\ Odessa I.I. Mechnikov National University \\ 2, Dvoryanska Str., Odesa, 65082, Ukraine \\ korobcukanna@gmail.com
}

The purpose of the article is to analyze source information in newspaper "Odessa Herald» to study the topic "History of the Odessa Institute of Noble Maiden". A phenomenon in the education system of the Russian Empire XVIII-XIX century there was the emergence of women's schools, institutes of noble maiden. Odessa Institute of Noble Maiden was a closed privileged educational establishment in the south of the Russian Empire, which belonged to the 1 st. level of the department of Empress Maria establishments. Beginning in 1827, the "Odessa Herald» was published twice a week in French (Journal d'Odessa) and Russian. It is important that the existence of the edition coincides with a significant period of operation of the Institute (65 years). The scientific novelty is that for the first time a search was conducted on the above topics in one of the leading local edition. The author carried out a frontal review of the "Odessa Herald" for 18291890. On the pages of the newspaper were found 200 notes reflecting the history of the Institute. Publications were divided into two groups: 1. News, 2. Announcements. The research methods are based on the main principles of historicist tradition, scientific objective, comprehensive approach and data classification. In order to achieve the purpose, the author uses a number of general scientific methods (analytic, synthesis, classification) as well as specific historical methods, such as problematic and chronological, comparative and method of periodization. The newspaper "periodically covered the news and announcements of the Institute, which aimed to inform parents, relatives and the public about past ceremonial events, changes in functioning, as well as the urgent needs of the school. At different times, they found their prominent place in various sections: "Inside", "Messages", "Local Chronicle", "Announcements". The materials in the "Announcements" section are the most quantitative, but insignificant for the study of the history of the Institute. Periodic articles on the issue of boarding houses, which were quite extensive in scope, are important for reproducing the lists of students of the Institute, household, etc. moments related to the functioning of the educational institution. Thus, the publications in the "Odessa Herald» are an auxiliary source on the history of the Odessa Institute of Noble Maiden. They complement the existing archives and those related to the functioning of the educational institution.

Key words: "Odessa Herald», noble Maiden institutes, women's education, nobleness, comprehensive education, the South Ukraine, department of Empress Maria establishments, closed girl's boarding schools.

Анна Коробчук

ORCID: https://orcid.org/0000-0001-9125-7036

Аспірантка кафедри історії України Одеський національний університет імені I.I. Мечникова Вул. Дворянська, 2, Одеса, 65082, Україна korobcukanna@gmail.com 


\section{ГАЗЕТА “ОДЕССКИЙ ВЕСТНИК” (1827-1894) ЯК ІСТОРИЧНЕ ДЖЕРЕЛО З ІСТОРІЇ ОДЕСЬКОГО ІНСТИТУТУ ШЛЯХЕТНИХ ДІВЧАТ}

Метою статті є аналіз джерелознавчої інформації на шпальтах газети «Одесский вестник» для вивчення теми «Історія Одеського інституту иляхетних дівчат». Наукова новизна полягає в тому, щзо вперше було здійснено пошук за даною тематикою в одному з провідних місиевих видань. Отже, публікації в «Одесском вестнике» $\epsilon$ допоміжним джерелом з історї Одеського інституту шляхетних дівчат. Статті в газеті «Одесский вестник» доповнюють наявні архівні та статистичні документи, щуо стосуються функціонування закладу освіти. Газета періодично висвітлювала новини та оголошення Інституту. У різний час вони знаходили своє місце в різних рубриках: "Внутрішні відомості», «Повідомлення», «Місцева хроніка», «Оголомення».

Ключові слова: "Одесский вестник», Одеський інститут иляхетних дівчат, Відомство установ імператрииі Марії, Одеське міське дівоче училище, Рада інституту иляхетних дівчат.

На початку модерної доби характерною рисою системи освіти Російської імперії кінця XVIII - початку XIX ст. стала поява жіночих закладів освіти, зокрема інститутів шляхетних дівчат [29]. Одеський інститут шляхетних дівчат (далі інститут) - закритий привілейований заклад освіти (длі - 30) на півдні Російської імперії, який належав до першого розряду відомства установ імператриці Марії [17, c. 8]. Інформація щодо історії установи розпорошена по різноманітних джерелах, одним із яких є матеріали тогочасної преси.

Періодичні видання вміщують цілий комплекс багатоманітної інформації й $є$ корисними під час вивчення різної проблематики. Ключова позитивна специфіка періодики як історичного джерела - близькість до подій [16]. Одним із таких унікальних видань є газета «Одесский вестник» (далі - ОВ) [16, с. 405].

Серед сучасних дослідників ОВ комплексним характером вирізняється дисертаційне дослідження Г. С. Левченко «Газета "Одесский вестник" (1827-1894): внесок у розвиток історичного краєзнавства на півдні України» [18]. Дослідниця звертає увагу, що зазначене вище видання $є$ джерелом інформації 3 цілої низки краєзнавчих питань $[18$, с. 30]. Через це фахівці 3 історії півдня України: І. С. Гребцова [12], Т. Г. Гончарук [10], Н. М. Діанова [13], В. В. Левченко [19], Л. В. Новікова [22], О. О. Синявська [11], В. М. Хмарський [30] та ін. залучають матеріали місцевої преси для дослідження краєзнавчої проблематики.

Газета ОВ, починаючи 31827 р. випускалась двічі на тиждень, французькою («Journal d'Odessa») та російською мовами [25]. Прикметно, що час існування видання збігається зі значним періодом функціонування Інституту (65 років).

Здійснювався фронтальний перегляд ОВ за 1829-1890 рр. На сторінках газети віднайдені 200 заміток, що відображають історію розвитку інституту. Публікації доцільно поділити на дві групи: 1. Новини про заклад освіти (розміщувалися в рубриках «Внутрішні відомості», «Повідомлення», «Хроніка» («Місцева хроніка»); 2. Оголошення (розміщувалися в рубриці «Оголошення»). Подані замітки на шпальтах газети відповідно у співвідношенні 50 на 50\%.

Найбільша концентрація статей про інститут сягає 1828-1854 рр. Впродовж цих років публікації були найбільш значними за обсягом, а відповідно інформативнішими. У публікаціях не зазначено авторство, але примітним є те, що в період 1829-1832 рр. О. Г. Тройницький викладав в інституті історію і географію, а 
згодом був інспектором класів. Паралельно він працював кореспондентом ОВ, а 3 1834 р. головним редактором [21, с. 76].

У рубриці «Внутрішні відомості» за 21 серпня 1829 р з'явилась перша публікація про 30 - 28 липня 1829 р. установу прийнято під протекторат Відомства установ імператриці Марії (далі - ВУІМ). 26 квітня 1830 р. в ОВ опубліковано новину, яка сповіщала про призначення та приїзд до міста нової директорки Інституту Луїзи Сукової [9, с. 133]. Непересічним в інституті було свято «Тезоіменитство» (іменини царської особи) імператриці Олександри Федорівни (дружина Миколи I, мати Олександра II), яке урочисто святкувалося вихованками та знатними гостями щороку 23 квітня. Про традиційний церемоніал засвідчують новини наступного дня у рубриці «Внутрішні відомості». На шпальтах газети відображалися переліки заходів серед яких: божественна літургія та молебень в інститутській церкві та вечірні гуляння. Серед почесних гостей заходів були генерал-губернатор граф М. С. Воронцов, одеський градоначальник О. І. Льовшин [6, с. 129].

Інститут суворо контролював правила внутрішнього розпорядку закладу. Проте за межами закладу закритої установи знаходилися батьки та родичі вихованок, які певною мірою робили внесок у виховання дівчат власним прикладом. Через це, Рада інституту публікувала оголошення, що стосувалися правил приватних візитів на шпальтах OB [8, c. 314$]$.

ОВ повідомляв про структурні зміни інституту, що відбулися у 1835 p. Першочергову роль в установленні зв'язків інституту відігравала належність закладу до ВУІМ. У 1835 р. під відомчий контроль було прийнято Одеське міське дівоче училище. Історія цього заклада овіти розпочинається з 1817 р., а його функціонування $\epsilon$ важливою віхою у становленні жіночої освіти на півдні України. У період 1817-1835 pp. контроль над навчальним процесом здійснював Рішельєвський ліцей [26]. Новий устав училища зайняв своє місце на першій сторінці ОВ [5, с. 401] за 1835 р. Важливо, що згідно $3 \S 2$ навчальний заклад мав підпорядковуватись Раді інституту й безпосередньо відомству імператриці. Рада інституту отримала фінансовий контроль над закладом, але об'єднувати гроші двох установ заборонялося (§19) [5, с. 401-402].

Головною подією, яка відзначалася помпезністю в інституті були випуски вихованок. На початку існування установи вони проходили кожні два роки 1 липня. Ця подія заслуговувала на розміщення подробиць заходу на велику статтю в місцевих виданнях. Підбиття підсумків навчання вперше повідомлялось на сторінках ОВ [7, c. 209-210].

В інституті під час кожного випуску відзначали найкращих вихованок, які за відмінні знання та зразкову дисципліну отримували нагороди під час урочистостей. Такими нагородами були: золотий вензель (інша назва - «шифр») імператриці, золота медаль, срібна медаль та похвальні листи. Важливо, що при уніфікованій системі нагород кожен відомчий заклад вирізнявся кольором стрічки. Публікації про випуски інформують, що кращі випускниці Інституту носили свій Золотий вензель на лівому плечі, на білій стрічці з блакитними окрайками [2, с. 297].

На сторінках ОВ за 1837 р. було опубліковано заповіт відставного полковника Курта: «О пожертвовании движимого и недвижимаго имения, в пользу Одесскаго института благородных девиц отставным полковником Куртом» [23, с. 694-695]. Прибутки 3 отриманого володіння давали шанс на освіту збіднілим та осиротілим дворянкам. У 1848 р. розпочався процес реорганізації освітнього процесу в інститутах. В одній із публікацій ОВ зазначалось, що всі вихованки закладу були поділені відповідно на два класи - старший та молодший, в кожному з них було два 
паралельних відділення, курс навчання мав тримати три роки. Прослідковується тенденція поступового збільшення кількості інституток, шо свідчило про зростання престижності жіночої освіти в регіоні. Того ж року, відбувся випуск 50 пансіонерок [17], що вдвічі більше, аніж десять років потому [3, с. 307-308].

Починаючи 31851 р. на шпальтах ОВ з'явилися оголошення зі списком претенденток на заміщення 11 вакантних місць в інституті [28]. Через кілька номерів, Рада інституту розміщує інформацію про тих, кому пощастило за жеребкуванням стати вихованками закладу. Проте дані оголошення не містять інформації до якого класу їх було зараховано чи хоча б вік дівчат.

Починаючи 31872 p. новини, які стосувалися різнобічних моментів функціонування установи розміщували в рубриці «Повідомлення», яка знаходилася на першій сторінці номера. Цього року було опубліковано новину про двадцять четвертий випуск інституту, який налічував 34 пансіонерки. Порівнюючи 3 публікаціями про перші випуски закладу, то замітка 1872 p. вирізняється лаконічністю. В ній перераховані всі випускниці, а окремо вихованки з відзнаками [14, с. 559].

ОВ від моменту заснування закладу публікувала в рубриці «Оголошення» запрошення від імені Рада інституту на торги до інституту, які були присвячені поставці необхідних промислових та побутових товарів. Головна тенденція розміщення подібних оголошень - повторна публікація (2-3 рази) у наступних випусках видання. Щорічно в ОВ під кінець або на початку календарного року 3'являлися переліки необхідних закупівель для закладу: дров, тканини, предметів побуту.

31871 р. актуальності набирали новини, які мали на меті сповіщення батьків та родичів про прийом нових дівчат до навчального закладу, канікули вихованок, проведення іспитів [15, с. 1].

29 грудня 1879 р. Одеський інститут шляхетних дівчат відзначав важливу подію - п’ятдесятирічний ювілей свого існування. До цієї події було опубліковано «Краткий исторический очерк пятидесятилетия Одесского института благородных девиц» [17]. Подробиці святкування заходу були опубліковані достатньо докладно на першій сторінці в ОВ за 1880 р. У публікації повністю процитовано головну промову церемонії, які оголосила пансіонерка старшого класу Софія Гунаролуло [33, с. 1-2]. 3 нагоди свят у стінах інституту проходили бали. Поте новини про них не потрапляли на шпальти ОВ. Винятково, у 1884 р. ОВ було зафіксовано про один 3 ошатніших балів у закладі. [24, с. 1].

На сторінках видання ОВ за 1890 р. оголошення, які повідомляли батьків та родичів про канікули та випуск вихованок було розміщено у рубриці «Місцева хроніка» [20, с. 3] на третій сторінці газети, що робило їх менш помітними та формальними. У 1880 р. у рубриці «Хроніка» [31, с. 2], яка розміщувалася на другій сторінці видання, знаходилось місце для повідомлень про балотування на заміщення вакантних пансіонерок, а у 1885 р. [32, с. 3] опубліковано новину про необхідність капітального ремонту будівлі.

Отже, ОВ періодично висвітлювала новини та оголошення інституту, які мали на меті повідомляти родичів вихованок та громадськість про минулі урочисті заходи, зміни у функціонуванні, а також нагальні потреби 30. У різний час вони знаходили місце в різних рубриках: «Оголошення», «Внутрішні відомості», «Повідомлення», «Місцева хроніка». Матеріали, розміщенні рубриці «Оголошення» $є$ найбільш кількісними, але малозначущими для дослідження історії Інституту. Періодичні статті 
про випуски пансіонерок, які були достатньо значними за обсягом є важливими для відтворення переліків вихованок Інституту, побутових та інших моментів, пов'язаних 3 функціонуванням 3О. Відповідно, публікації в ОВ являють собою допоміжне джерело з історії Одеського інституту шляхетних дівчат. Статі в газеті доповнюють наявні архівні та, що стосуються функціонування закладу освіти.

\section{Джерела та література:}

1. Внутреннія известія, Одесса, 21-го Августа // Одесский вестник (далі ОВ). - 1829. - №67. C. 281.

2. Внутреннія известія, Одесса, 23-го Іюля. // ОВ. - 1846. - №59. - С. 297.

3. Внутреннія известія, Одесса, 23-го Іюля // ОВ. - 1848. №59. - С. [307-308].

4. Внутреннія известія, Одесса, 30-го Ноября. // ОВ. - 1862. - №130. - С. 591.

5. Внутреннія известія. Одесса, 17-го Декабря // ОВ. - 1835. - №101. - С. 401-402.

6. Внутреннія известія. Одесса, 24-го Апреля // ОВ. - 1834. - №33. - С. 129.

7. Внутреннія известія. Одесса, 2-го Іюля // ОВ. - 1832. - №53. - С. 209-210.

8. Внутреннія известія. Одесса, 3-го Октября // ОВ. - 1834. - №79. - С. 314.

9. Внутреннія известія. Одесса, 26-го Апреля // ОВ. - 1830. - №34. - С. 133.

10. Гончарук Т. Г. Інформація про українські видання на сторінках газети "Одесский вестник" 1830-х - першої половини 1840-х рр.: від оголошень до рецензій / Т. Г. Гончарук // Інтелігенція і влада. Серія : Історія. - 2013. - Вип. 28. - С. 159-166.

11. Гончарук Т. Г. "Одесский вестник" про недільні школи початку 1860-х рр. / Т. Г. Гончарук, О. О. Синявська // Записки історичного факультету. - 2004. - Вип.15. - С. 408-422.

12. Гребцова И. С. Периодическая печать: в общественном развитии Южного степного региона Российской империи (Вторая треть ХІХ в.) / Гребцова И. С. - Одесса : Астропринт, 2002. - 408 с.

13. Діанова Н. Дослідження Науково-просвітницької діяльності архієпископа Інокентія (Борисова) в дореволюційній історіографії / Н. Діанова // Історіографічні дослідження в Україні: Зб. наук. пр. 2013. - Вип. 23. - С. 93-102.

14. Извещенія. От совета Одесскаго института благородных девиц // ОВ. - 1872. - №138. - С. 559.

15. Извещенія. Совет Одесскаго института благородных девиц // ОВ. - 1874. - №85. - С. 1.

16. Історичне джерелознавство / Я. С. Калакура, І. Н. Войцехівська, С. Ф. Павленко, Б. І. Корольов, М. Г. Палієнко; гол. ред. С. В. Головко. - К.: Либідь, 2002. -488 с.

17. Краткий исторический очерк пятидесятилетия Одесского Института благородных девиц. - Одесса, 1879. -44 c.

18. Левченко Г. С. Газета "Одесский вестник" (1827-1894): внесок у розвиток історичного краєзнавства на Півдні України : дис ... канд. іст. наук / Галина Сергіївна Левченко. - Одеса, 2017. $-373 \mathrm{c}$.

19. Левченко В. В. Олександро-Невська церква Новоросійського університету: історія, персоналії, документи / В. В. Левченко, Г. С. Левченко. - Одеса: ФОП Бондаренко М. О., 2015. - 360 с.

20. Местная хроника. // ОВ. - 1890. - №118. -С. 3.

21. Модзалевский В. Л. Тройницкие / В. Л. Модзалевский //Малороссийский родословник. - 1996. - Т. 5. Вып. 1. - С. 76-87.

22. Новікова Л. В. Святкування тисячоліття православної народної Болгарської церкви в Одесі, 3 травня 1870 р. / Л. В. Новікова // Юго-запад. Одессика=Південний Захід. Одесика : історикокраєзнавчий альманах. - 2016. - Вип. 21. - С. 77-88.

23. О пожертвовании движимого и недвижимого имения, в пользу Одесскаго института благородных девиц отставным полковником Куртом. // ОВ. - 1837. - №58. - С. 694-695;

24. Одесса, 15-го ноября. Бал в институте благородных девиц. // ОВ. - 1884. - №252. - С. 1.

25. ОВ. Энциклопедический словарь Брокгауза и Ефрона [Електронний ресурс]. - Режим доступа: https://ru.wikisource.org/wiki/ЭСБЕ/Одесский_Вестник. (дата 29.11.20). - Назва з екрану.

26. Одесское городское девичье училище (ул. Старопортофранковская, 32). 2015. [Електронний pecypc]. - Режим доступа: https://www.shukach.com/ru/node/44244 (дата 29.11.20). - Назва з екрану.

27. От Совета Одесского Института Благородных Девиц // ОВ - 1837. - №38. 
28. От Совета Одесскаго Института Благородных Девиц // ОВ. - 1851. - №48.

29. Поздняков А. Н. Институты благородных девиц в системе образования России второй половины XVIII начала XIX в. [Електронний ресурс]. / А. Н. Поздняков. - Режим доступа: https:/cyberleninka.ru/article/n/instituty-blagorodnyh-devits-v-sisteme-obrazovaniya-rossii-vtoroypoloviny-xviii-nachala-xix-veka/viewer (дата 29.11.20). - Назва з екрану.

30. Хмарський В. М. Археографічна діяльність Таврійської вченої архівної комісії наприкінці XIX - на початку XX ст. (1896-1909) / В. М. Хмарський // Записки історичного факультету. - 2004. Вип. 15. - С. 433-449.

31. Хроника. // ОВ. - 1880. - №156. - С. 2.

32. Хроника. Осмотр зданія института благородных девиц. // ОВ. - 1885. - №192. - С. 3.

33. Хроника. Пятидесятилетній юбилей Одесскаго института благородных девиц. // ОВ. - 1880. №1.

\section{References:}

1. Vnutrenniya izvestiya, Odessa, 21-go Avgusta, 1829. Odesskij vestnik, 67, s. 281. [in Russian]. 2. Vnutrenniya izvestiya, Odessa, 23-go Iyulya, 1846. Odesskij vestnik, 59, s. 297. [in Russian]. 3. Vnutrenniya izvestiya, Odessa, 23-go Iyulya, 1848. Odesskij vestnik, s. [307-308]. [in Russian]. 4. Vnutrenniya izvestiya, Odessa, 30-go Noyabrya, 1862. Odesskij vestnik, 130, s.591. [in Russian]. 5. Vnutrenniya izvestiya, Odessa, 17-go Dekabrya, 1835. Odesskij vestnik, 101, s. 401-402. [in Russian].

6. Vnutrenniya izvestiya, Odessa, 24-go Aprelya, 1834. Odesskij vestnik, 33, s.129. [in Russian]. 7. Vnutrenniya izvestiya, Odessa, 2-go Iyulya, 1832. Odesskij vestnik, 53 s. 209-210. [in Russian]. 8. Vnutrenniya izvestiya, Odessa, 3-go Oktyabrya, 1834. Odesskij vestnik, 79, s. 314. [in Russian]. 9. Vnutrenniya izvestiya, Odessa, Aprelya 26, 1830. Odesskij vestnik, 34, s. 133. [in Russian]. 10. Honcharuk, T. H., 2013. Informatsiia pro ukrainski vydannia na storinkakh hazety "Odesskij vestnik" 1830-kh-pershoi polovyny 1840-kh rr.: vid oholoshen do retsenzii. Intelihentsiia $i$ vlada, Seriia : Istoriia, 28, s. 159-166. [in Ukrainian].

11. Honcharuk, T. H. and Syniavska, O. O., 2004. "Odesskij vestnik" pro nedilni shkoly pochatku 1860-kh rr. Zapysky istorychnoho fakultetu, 15, s. 408-422. [in Ukrainian].

12. Hrebtsova, I. S., 2002. Periodicheskaya pechat': v obshchestvennom razvitii Yuzhnogo stepnogo regiona Rossijskoj imperii (Vtoraia tret 19 v.). Odessa: Astroprynt [in Russian].

13. Dianova, N. M., 2013. Doslidzhennia Naukovo-prosvitnytskoi diialnosti arkhiiepyskopa Inokentiia (Boryova) v dorevoliutsiinii istoriohrafii. Istoriohrafichni doslidzhennia v Ukraini: Zb. nauk. pr., 23, s. 93-102. [in Ukrainian].

14. Izveshcheniia. Ot soveta odesskago instituta blagorodnyh devic, 1872. Odesskij vestnik, 138, s. 559. [in Russian].

15.Izveshcheniya. Sovet Odesskago instituta blagorodnyh devic, 1874. Odesskij vestnik, 85, s.1. [in Russian].

16. Kalakura, I. S., 2002. Istorychne dzhereloznavstvo. Kyiv: Lybid'. [in Ukrainian].

17. Kratkij istoricheskij ocherk pyatidesyatiletiya Odesskogo instituta Blagorodnyh devic, 1879.. Odessa. [in Russian].

18. Levchenko, H. S., 2017. Hazeta "Odesskij vestnik" (1827-1894): vnesok u rozvytok istorychnoho kraieznavstva na Pivdni Ukrainy [The newspaper «Odessa Herald» (1827-1894): contribution to the development of local history in the south of Ukraine]. Ph.D. thesis, Odesa. [in Ukrainian].

19. Levchenko, V. V., 2015. Oleksandro-Nevska tserkva Novorosiiskoho universytetu: istoriia, personalii, dokumenty. Odesa: FOP Bondarenko M. O. [in Ukrainian].

20. Mestnaya hronika, 1890. Odesskij vestnik, 118, s. 3 [in Russian].

21. Modzalevs'kyj, V. L., 1996. Malorosïj'kyj rodoslovnyk, 5(1).[in Russian].

22. Novikova, L. V., 2016. Sviatkuvannia tysiacholittia pravoslavnoi narodnoi Bolharskoi tserkvy v Odesi, 3 travnia 1870 r. Yuho-zapad. Odessyka=Pivdennyi Zakhid. Odesyka : istorykokraieznavchyi almanakh, 21, s. 77-88. [in Ukrainian]. 
23. O pozhertvovanyy dvyzhymoho y nedvyzhymoho ymenyia, v polzu Odesskaho ynstytuta blahorodnыkh devyts otstavnыm polkovnykom Kurtom, 1837. Odesskij vestnik, 58, s. 694-695 [in Russian].

24. Odessa, 15-go noyabrya. Bal v institute blagorodnyh devic, 1884. Odesskij vestnik, 252, s. 1. [in Russian].

25. Odesskij Vestnik. Enciklopedicheskij slovar' Brokgauza i Efrona. [online]. Available at: $<$ https://ru.wikisource.org/wiki/ЭSBE/Odesskyi_Vestnyk> [Accessed 29 November 2020]. [in Russian].

26. Odesskoe gorodskoe devich'e uchilishche (ul. Staroportofrankovskaya, 32). [online]. Available at: <https://www.shukach.com/ru/node/44244> [Accessed 29 November 2020]. [in Russian].

27. Ot Soveta Odesskogo Instituta Blagorodnyh Devic, 1837. Odesskij vestnik, 38, s. 461. [in Russian].

28. Ot Soveta Odesskago Instituta Blagorodnyh Devic, 1851. Odesskij vestnik, 48 [in Russian].

29. Pozdnyakov, A. N. Instituty blagorodnyh devic v sisteme obrazovaniya Rossii vtoroj poloviny 18 nachala $19 v$. [online]. Available at: <https://cyberleninka.ru/article/n/instituty-blagorodnyhdevits-v-sisteme-obrazovaniya-rossii-vtoroy-poloviny-xviii-nachala-xix-veka/viewer> [Accessed 29 November 2020]. [in Russian].

30. Khmarskyi, V. M., 2004. Arkheohrafichna diialnist Tavriiskoi vchenoi arkhivnoi komisii naprykintsi 19 - na pochatku 20 st. (1896-1909). Zapysky istorychnoho fakultetu, 15, s. 433-449. [in Ukrainian].

31. Khronika, 1880. Odesskij vestnik, 156, s. 2. [in Russian].

32. Khronika, 1885. Osmotr zdaniya instituta blagorodnyh devic. Odesskij vestnik, 192, s. 3[in Russian].

33. Khronika, 1880. Pyatidesyatiletnij yubilej Odesskago instituta blagorodnyh devic. Odesskij vestnik, 1, s. 1-2. [in Russian].

Отримано: 29.11.2020 p. 
ISSN 2519-2523 (print)

DOI: $10.18524 / 2519-2523.2020 .15 .218679$

УДК 94:323.272(477.74-21)“1905”

\section{THE CITY MAYORS OF ODESSA IN THE CIRCUMSTANCES OF THE REVOLUTIONARY EVENTS OF 1905}

\section{Viktoriia Herasymenko}

ORCID: http://orcid.org/0000-0003-2859-0105

Post-graduate student

At the Department of Ukrainian History

Odessa I.I. Mechnikov National University

2, Dvoryanska Str., Odessa, 65082, Ukraine

samvika2086@gmail.com

In the beginning of $X X^{\text {th }}$ century the imperial, regional, world socio-economic and political processes significantly influenced on the development of Odessa. The unresolved nature of many of the city's internal problems and external influences exacerbated social tensions: the number of antigovernment protests and protests grew, and the labor movement intensified. The article considered the activity of the heads of city self-government during the revolutionary events of 1905. Odessa has gone through three procedures for electing a lord mayor in six months. The activity of personalities of mayors as $P$. Zelenyi, P. Kryzhanovskyi and V. Protopopov are revealed through their decisions, work in the Duma, interviews and rewievs from the press and contemporaries.

$P$. Zelenyi was a well-known writer with a law education, who took care of charitable societies and educational institutions, participated in the political sphere. His activity as the mayor of Odessa lasted for 8 years (1898-1905).

P. Kryzhanovskyi was the lawyer, who connected his life with the judiciary, worked in various cities of the empire. In the "Odessa News» he appeared as a public figure in the city council under the leadership of mayor G.G. Marazli. Kryzhanovskyi's total tenure as mayor was only 13 months (1897, 1905).

V. Protopopov was an assistant to the famous lawyer Richter in Odessa, he joined the editorial activities of the Odessa and Elizavetgrad press, for a long time he was the chairman of the jury of the Odesa Judicial Chamber. In December 1905, the devoted lawyer V. Protopopov accepted the exhausted Odessa as a mayor for the next four years (1905-1908).

The material for the investigation was singled out from "Odessa News» and "Odessa Listok» newspapers. More that 360 newspapers were analyzed. In the research, the following methods were used: the methods of synthesis and analysis, structural and comparative-historical methods. The revealed details are necessary in the perspective of biographical and prosopographic researches of the Odessa mayors of the first half of the $X X^{\text {th }}$ century.

Keywords: Odessa, 1905, mayor, battleship «Potemkin», pogrom (riot).

Вікторія Герасименко

ORCID http://orcid.org/0000-0003-2859-0105 Аспірантка кафедри історії України Одеський національний університет імені I.I. Мечникова Вул. Дворянська, 2, Одеса, 65082, Україна samvika2086@gmail.com 


\section{МІСЬКІ ГОЛОВИ ОДЕСИ НА ТЛІ РЕВОЛЮЦЙНИХ ПОДІЙ 1905 РОКУ}

У статті розглянуто питання діяльності очільників міського самоврядування в період реакційних подї 1905 року. Одеса пережила три процедури виборів лорд-мера за півроку. Особистості міських голів - П. О. Зеленого, П.А. Крижановського та В.Я. Протопопова - розкриваються через їх рішення, роботу в Думі, інтерв'ю та характеристики $з$ боку преси й сучасників. Виявлені подробиці є необхідними в ракурсі біографічних та просопографічних досліджень міських голів Одеси першої половини ХХ століття.

Ключові слова: Одеса, 1905, міський голова, броненосець «Потьомкін», погром.

Завжди яскраві сторінки історії полонять науковців на довгий час. Цілі покоління дослідників можуть розробляти і розкривати з різних боків наукові теми, що пов'язані 3 політичними, військовими, соціально-економічними та культурницькими подіями минулих століть. Революційні події 1905-1907 рр. також не залишаються без уваги. Акцентуючи погляд саме на регіональному контексті, початок всеросійської революції мав місце й в історії Одеси. Важливо розуміти та вивчати всі аспекти питань, особливо звертаючи увагу на реакцію та діяльність різних груп населення під час бурхливих соціально-економічних та політичних подій. Метою даної статі $є$ висвітлення діяльності та реакцій з боку очільників одеського міського самоврядування на події 1905 р., що розгортались в Одесі.

Побіжно дана тематика розглядалась в книзі відомого літературного, громадського та політичного діяча, лауреата Нобелівської премії 3 літератури О.Солженіцина та публікаціях сучасних істориків та краєзнавців Т. Гончарука [5], В. Малахова й Б. Степаненка [11] та П. Герлігі [3]. Основними джерелами є тогочасна преса - газети «Одеський листок» та «Одеські новини».

На початку XX ст. Одеса залишалась одним із головних торговельнопромислових центрів Російської імперії, посідаючи особливе місце в економічному, суспільному та культурному житті країни. Місто стало осередком розвитку різних галузей фабрично-заводської промисловості, що безпосередньо вплинуло на характер зовнішньої торгівлі.

В той самий час на розвиток Одеси суттєво впливали загальноросійські, регіональні, світові соціально-економічні та політичні процеси. Невирішеність багатьох внутрішніх проблем міста та зовнішні впливи зумовили загострення соціальної напруги: зростала кількість антиурядових виступів, акцій протесту, активізувався робітничий рух [8, с. 195]. Життя місцевого самоврядування теж було насичене подіями. 1905 рік - це єдиний рік, коли посаду міського голови обіймали три людини - П. О. Зелений (1839-1912), П. А. Крижановський (1847(8)-?) та В. Я. Протопопов (1846-1914).

Події початку 1905 р., а саме Кривавої неділі, знайшли широкий відгук в Одесі. Більшовики випустили прокламацію, в якій закликали до повалення самодержавства. Державою почала ширитися хвиля незадоволення, поступово зростає кількість страйків на виробничих підприємствах, де працівники вимагали поліпшення умов праці та підвищення заробітної платні. Ситуація почала змінюватися не на користь влади - імператор Микола II обіцяє пом'якшити цензурні правила, розширити права місцевого самоврядування, розробити проект скликання народних представників для законодавчих пропозицій.

В цей час органи самоврядування Одеси очолює Павло Олександрович Зелений. На цій посаді він вже працював 3 лютого 1898 р. [19]. Відомий літератор 3 юридичною освітою, що опікувався благодійними товариствами та навчальними 
закладами, брав участь у політичній сфері. Народився 1839 р. в Слисаветградському повіті в родині поміщика, закінчив Харківський університет й потім успішно працював в земствах Херсонської губернії [7]. 3 1870-х рр. - працював в редакції «Одеського вісника», паралельно намагаючись залучити до публікацій в газеті кращих українських письменників і громадських діячів. Згодом майбутній міський голова тривалий час був директором Херсонського земського банку в Одесі, обирався почесним мировим суддею та гласним Одеської думи [4, с. 218]. Діяльність П. О. Зеленого, саме як очільника Одеси, продовжувалась протягом 8 років, з 1898 до 1905 pp. [2, с. 3].

У січні 1905 р. він вніс на обговорення гласних доповідь, де «наполягав на скасуванні циркулярів, що затискують викладання у школах малоросійською мовою, на складанні окремих посібників українською мовою, на допущенні малоросійських книг у шкільні й народні бібліотеки і взагалі на скасуванні розпоряджень 1863, 1876 і 1881 рр.» [20; 32]. 13 лютого 1905 р. члени «Наради представників одеської преси» під головуванням П. О. Зеленого - І. Луценко С. Шелухин та Д. Сигаревич підіймали питання про зняття заборон з української мови [33].

Як публічна особа, за період свого керівництва місцевим самоврядуванням, П. О. Зелений був присутній на багатьох урочистостях: на освяченні споруд церковних, освітніх, громадських, медичних та промислових організацій. В квітні 1905 р. відбулась закладка нової будівлі для міської публічної бібліотеки. Міський голова виголосив промову, де прослідковувався відтінок наслідків зовнішньополітичних конфліктів: «... майбутне нашої батьківщини належить їй, нашій багатостраждальній молоді. Старі люди сходять зі сцени. Нашим спадкоємцям доведеться працювати на жнивній ниві ... лише в небагатьох кращих умах та серед молоді жевріє вогонь і жива віра в неминучість загальнолюдського майбутнього i ненависть до китайського застою» [22].

У березні 1905 р. почались проблеми під час виборів нового складу гласних для наступного терміну. За два тури не змогли набрати необхідних 80 чоловік, а лише 58 - це ускладнювало діяльність Думи [21]. П. О. Зелений під час службого відрядження в Петербурзі намагався домогтись позитивного рішення для скликання третього туру виборів - але цьому не судилось відбутися. І можливо, це одна із причин, чому Зелений починає вголос казати, що він не сподівається бути вкотре обраним міським головою. В замітці «Вибори голови» одним із сучасників подій вказується, що «Відхід п. Зеленого від справ міської управи багатьма передбачався раніше ... про причини цього факту ми зараз не будемо говорити. Одне тільки ясно, що незважаючи на свої прогресивні погляди і широкий суспільний світогляд, п. Зелений не зміг втілити їх в життя, в своїй діяльності у складі управи, не зміг уникнути багатьох прикрих помилок і компромісів, що відбилися несприятливо на міському господарстві ...» [23].

Залишити пост міського голови, у квітні 1905 р., Зеленого примусили консервативно налаштовані гласні, які вимагали від Зеленого «поменше м'якості, побільше владності». Тому, Павло Олександрович, якому минав сьомий десяток, залишився гласним думи, але зосередився на літературній праці [7]. Останній раз він 3'явився в міській думі в день оприлюднення маніфесту 17 жовтня і згодом зник, щоб більше ніколи не повернутися до Одеси, де залишилась одна 3 важливих віх його життя [11, с. 88].

Після відмови професора С.П. Ярошенко від посади очільника Одеси, на повторних виборах 20 травня 1905 р. міським головою був вже вдруге обраний дійсний статський радник Петро Адамович Крижановський. Народився в 1847 (1848) р. в Бессарабії в сім’ї майбутнього міського голови Кишинева [6, арк. 2 зв-3]. 
Закінчив Новоросійський університет, пішов на службу по судовому відомству. До призначення в Одесі, відзначився на посаді прокурора таганрогського окружного суду [12]. В «Одеських новинах» 3'являється в якості гласного міської думи за керівництва міського голови Г. Г. Маразлі [24; 31, с. 209]. Вперше посаду міського голови П. А. Крижановський заняв у 1897 р., але пробув при владі недовго - на початку грудня в.о. градоначальника В. П. Старков отримав прохання про звільнення від нього [26]. Вся ця історія висвітлювалась на сторінках газети «Одеські новини» майже всіх грудневих випусків.

Сам П. А. Крижановський не розкривав до кінця всіх причин своєї відставки. Одна 3 них полягала в його самопочутті, про що він заявив депутації гласних, які намагались відмовити його від відставки: «остаточно дестабілізувався його нервовий стан, міські справи залишили його без спокійного сну» [28]. Можливо, ще одна причина могла бути в певних суперечках між Крижановським та пресою, які точилися протягом його діяльності: «майже $з$ першого дня на посаді міського голови, міською пресою проти мене була розпочата війна - війна непристойна...якщо вірити всім тим інсинуаціям, то я шахрай, то дурний...» [29]. Опосередковано причини відставки згадувалися в замітках Рашковського: «Двадцять років в судовому відомству залишили свій відбиток...він звик до сурової дисципліни...але не всі гласні бажали поступатися своєю активною позицією...п. Крижановський вимагав до себе такої довіри, якої ще не мав ні один громадський діяч...він не сприймав критику, і бажав, щоб його доповіді або статті кошторису з його підписом приймались одноголосно і без сперечань...» [27].

Вже у 1905 р., під час своєї промови, П. А. Крижановський зазначив, що врахує досвід 1897 р. і як ніхто усвідомлює всю тяжкість покладених на нього обов’язків: «Я обіцяю неухильно охороняти інтереси міста ... віддавати весь свій час ... сили на служіння місту, обіцяю твердо відстоювати права громадського самоврядування».

Особливого розмаху набули революційні події в червні 1905 р. Місто охопив загальний політичний страйк, який розпочали робітники Пересипу [11, с. 93]. Пізніше до них приєднались робітники Молдаванки та інших районів. На вулицях з'явились барикади, відбулися збройні сутички з поліцією і козаками, було поранено багато робітників. В розпалі боротьби на світанку 15 червня на Одеський рейд прибув повсталий броненосець «Потьомкін» 3 червоним прапором на щоглі. Робітники захоплено вітали революційний броненосець. Похорон матроса-більшовика Г. М. Вакуленчука, вбитого офіцером на кораблі, перетворився на грандіозну демонстрацію солідарності робітників і матросів.

На час літніх подій в місті був відсутній міський голова П. А. Крижановський. Своє враження він виголосив в телеграмі: «Звертаюся до мешканців Одеси телеграмою 3 Москви, куди я приїхав на нараду Міських голів... запрошених спільно обговорити i виробити ті заходи, які можуть найкращим чином служити потребам населення, про що i піклуються міста. I в такий час тут, в Москві, я дізнаюся, що в Одесі відбуваються сумні заворушення, які завдають шкоди всьому міському населенню і в тому числі тим самим особам, які ініціювали заворушення, та їх сім'ям. Як виборний представник одеського міського громадського самоврядування, зобов'язаний обов'язком і совістю піклуватися про благо населення Одеси, і як людина, що гаряче любить Одесу, я також гаряче переконую неспокійних заспокоїтися і тим дати виборним людям можливість мирним шляхом служити для народного блага» [25].

Нове піднесення революційної хвилі почалося восени 1905 р. і переросло у Всеросійський політичний страйк. Першими в боротьбу включилися залізничники. 12 жовтня жоден потяг не вийшов 3 міста [9; 10]. Згодом до них приєднались робітники, 
студенти та частина інтелігенції. Службовці міського самоврядування теж приєднались до загального політичного страйку [17]. Протистояння посилися після оголошення Маніфесту 17 жовтня. Протягом тижня, Одесою прокотилася хвиля єврейських погромів [11, с. 106, 108]. Чимало публікацій в пресі містили інформацію про ймовірну причетність влади - градоначальника, поліції, військових - до дій, що спричинили погром. В тому числі, коли необхідно було захистити громадян, городові були зняті зі своїх постів, попередньо Д. Б. Нейдгардт негативно поставився до створення міської поліції - хоча матеріально городових утримувало саме міське самоврядування, а впливу на них не мало. Градоначальник не скористався й допомогою військових загонів з боку Каульбарса [3, с. 290]. Один із гласних міської Думи, П. Климович у своїй заяві в газеті «Одеський листок» стверджував, що «поліція завдяки своїй безсоромній та беззаконній поведінці» під час погрому втратили довіру одеситів [5, с. 155].

Діяльність міського голови в цей період більш-менш була схожа на попередні роки - турботи про одеський міський театр [13; 15], формування списків виборців до Державної Думи [15], продовження влаштування конно-залізничних доріг в місті [14]. Реакція на події за участі студентів мала місце - було прийнято рішення про створення комітету громадської безпеки та виголошено протест через побиття дітей городовими Також на приватному засіданні гласних, ради Новоросійського університету та представників різних союзів постало питання про створення міської поліції, тому що діючі городові підпорядковувались градоначальнику, але утримувались 3 місцевого бюджету [16]. 18 жовтня міський голова був викликаний на нараду до градоначальника Нейдгардта. П. А. Крижановський повідомив про всі вимоги союзів, в тому числі і про розброєння поліції і додав, що під час похорон це буде необхідним для заспокоєння населення [18; 34, с. 149].

У зв'язку з великими безладами в місті 19 жовтня 1905 р., П.А. Крижановський складає 3 себе обов'язки міського голови, а 13 грудня відмовляється від посади гласного Думи [17]. 30 жовтня на шпальтах «Одеського листка» 3'явився «Звіт П. А. Крижановського про причини відмови від посади». Основний акцент був на тому, що службовці з різних відділів міської управи об'єднались і погрожували бастуванням через свій комітет та інших службовців, якщо Дума не виконає їхніх умов. Засідання Думи не могли більше проходити в звичному режимі, тому що зала Біржі наповнювалась публікою до 700-800 осіб, й будь-які пропозиції міського голови та обговорення гласних просто тонули в атмосфері паніки та загального мітингу населення. Гласним та лорд-меру залишалось шукати приватні приміщення та проводити закриті засідання, щоб публіка не спричинила зриву обговорень питань. Запропонований дорадчий комітет при міському голові почав ставити власні умови, які не збігалися ні з завданнями міського самоврядування, ні з позиціями міського голови. П.А. Крижановського бентежили постійні заклики публіки врятувати та захистити їх від загонів козаків - потрібно було кожен раз звертатися до командуючого військами $з$ проханнями заспокоїти публіку. Останньою краплею в чаші терпіння П. А. Крижановського стали смутні події, що відбувалися на вулицях міста «Я бачив, що населення роздвоїлось, витворились дві течії, їх зіткнення призведе до кровопролиття...у міського самоврядування немає ніяких засобів для попередження цієї біди, ніяке моє втручання...не може зупинити майбутні жахи i ніяке звернення до населення в даних умовах не є засобом заспокоєння, а навпаки, може тільки ще більше розпалити жагу у ворогуючих сторін...» [18].

На наступні чотири роки міським головою стає адвокат Василь Якович Протопопов. Народився в 1846 р. в Кременчузі в сім’ї священнослужителя. В Одесу 
він потрапив вже як студент, завершив своє навчання в Новоросійському університеті. В 1860-х рр. молодий юрист став помічником відомого адвоката Ріхтера. Працював деякий час в одеській газеті «Новороссийский телеграф». У 1870-х pp. розпочав самостійну адвокатську діяльність в Слизаветграді, був редактором першої міської газети «Елисаветградський листок». Набравшись досвіду, знову повернувся до Одеси, де поступово почав просуватися по кар'єрних сходинках. 31900 р. 3'являється у списках гласних Одеської Думі [1, с. 234].

В. Я. Протопопов був обраний міським головою Одеси наприкінці грудня 1905 р. Цікавий факт, що обрання В. Протопопова сприймалась як подія неочікувана, через його скромність та помірну активність на засіданнях думи. Й сам Василь Якович в інтерв’ю наголошував, що він дійсно не збирався балотуватись, але гласні «підштовхнули» його на це рішення. Деякі присутні на виборах в думі були приголомшені результатом голосування. За свідченням преси: «.. заколонній публіці обрання В. Я. Протопопова надзвичайно не сподобалося, і оголошений результат вона зустріла шиканням. «Це ганьба» крикнув хтось із публіки ...» [30]. Тем не менш, завдяки завзятості В. Я. Протопопова, діяльність всіх підрозділів міської управи продовжувалася. Як відмічали сучасники, «... він виявив велику працездатність, прагнення особисто вникати у все, доступність, коректність і бажання, в міру сил і можливостей, очистити міське управління від проникнення в нього «негативних»елементів» [11, с. 119].

На той час, новому міському голові потрібно було співпрацювати 3 різноплановим політичним клубом, які просували власні питання та потреби, а не опікувалися нагальними проблемами міста.

Отже, П.О. Зелений, П.А. Крижановський та В.Я. Протопопов були затягнуті в швидкий потік неспокійних подій 1905 р. в Одесі. В ході роботи з міською Думою та управою їм необхідно було відстоювати власні пропозиції, лавіювати між різними політичними силами та намагатися утримувати нейтральну атмосферу в місті. Прогресист П.О. Зелений в останній рік свого мерства вже не мав такої підтримки, як це було на початку. Вдруге обраний, «удрученный опытом 1897 года», П. А. Крижановський знову не витримав тиску посади й обов'язків, залишивши міське самоуправління під час єврейських погромів на свого заступника К. Андрієвського. I третій, новий персонаж, відданий своїй справі юрист В. Я. Протопопов приймає знесилену Одесу на найближчі чотири роки.

\section{Джерела та література:}

1. Герасименко В. Міський голова Одеси 1905-1908 pp. Василь Якович Протопопов: короткий історичний портрет / В. Герасименко // Південний захід. Одесика. Історикокраєзнавчий науковий альманах. Одеса: Друкарський дім, 2018. - Вип. 25.- С. 233-239.

2. Герасименко В. Павло Олександрович Зелений як міський голова Одеси (1898-1905) / В. Герасименко / В. Герасименко // Хаджибеївські читання: матеріали Всеукраїнської наукової конференції з історії України для студентів та аспірантів. - Одеса: видавець Букаєв Вадим Вікторович, 2018. - С. 3-8.

3. Герлігі П. Одеса : історія міста, 1794-1914 / П. Герлігі. - К. : Критика, 1999. - 382 с.

4. Гончарук Т. Г. Ініціативи міського голови Одеси П. О. Зеленого на сторінках «Известий Одесской городской думы» (1898-1905) / Т. Г. Гончарук, В. В. Герасименко, І. М. Жиленкова // Інтелігенція і влада. Серія: Історія. - 2018. - Вип. 38. - С. 214-230.

5. Гончарук Т. До питання про висвітлення подій єврейського погрому жовтня 1905 р. в Одесі на сторінках місцевої преси (за матеріалами газет «Одесский листок» та «Одесские новости») / Т. Г. Гончарук // Південний захід. Одесика. Історико-краєзнавчий науковий альманах. - Одеса: Друкарський дім, 2020. Вип. 29. - С. 153-162. 
6. Державний архів Одеської області. - Ф. 2. - Оп. 8. - Спр. 2394. - 9 арк.

7. Зленко Г. Павло Зелений - одеський міський голова і літератор [Електронний ресурс]. /

Г. Зленко // Київська старовина. - 1997. - № 6. - Режим доступа: http://library.kr.ua/elmuseum/zem/zelenyy/index.html (дата 24.11.20). - Назва з екрану.

8. Історія Одеси / Колектив авторів. Гол. Ред. В. Н. Станко. - Одеса: Друк, 2002. - 560 с.

9. К забастовке железнодорожних служащих // Одесский листок (далі - ОЛ). - 1905. 15 октября.

10. К прекращению движения поездов // ОЛ. - 1905. - 13 октября.

11. Малахов В. П. Одесса, 1900-1920 / В. П. Малахов, Б. А. Степаненко // Люди... События... Факты... - Одесса: Издательство «Optimum», 2004. - 488 с.

12. Новый Одесский городской глава // Одесские новости (далі ОН), - 1897. - 21 февраля.

13. ОЛ. - 1905. - 1 октября.

14. ОЛ. - 1905. - 5 октября.

15. ОЛ. - 1905. - 9 октября.

16. ОЛ. - 1905. - 15 октября.

17. ОЛ. - 1905. - 26 октября.

18. ОЛ. - 1905. - 30 октября.

19. ОН. - 1898. - 24 февраля.

20. ОН. - 1905. - 28 января.

21. ОН. - 1905. - 3 апреля.

22. ОН. - 1905. - 20 апреля.

23. ОН. -1905 . -28 апреля.

24. ОН. - 1905. - 21 мая.

25. ОН. $-1905 .-16$ июня.

26. ОН. - 1897. - 5 декабря.

27. ОН. - 1897. - 6 декабря.

28. ОН. - 1897. - 13 декабря.

29. ОН. - 1897. - 15 декабря.

30. ОН. - 1905. - 24 декабря.

31. Паламарчук В. Міський голова Петро Адамович Крижановський - «казковий принц, що має розбудити сплячу красуню Одесу» / В. Паламарчук // Південний захід. Одесика. Історико-краєзнавчий науковий альманах. - Одеса: Друкарський дім, 2017. - Вип. 23. - С. 208212.

32. С.-Л. Памяти П.А. Зеленого / С.-Л. // ОЛ. - 1912. - 22 августа.

33. Совещание представителей одес. печати // ОЛ. - 1905. - 15 февраля.

34. Солженицын А. И. Двести лет вместе: в 2 т. [Електронний ресурс] / А. И. Солженицын - М.: Русский путь, 2001. - Т. 1. - 512 с. - Режим доступа: http://book-online.com.ua/read.php?book=4500 (дата 24.11.20). Назва з екрану.

\section{References:}

1. Herasymenko, V., 2018. Mis'kyy holova Odesy 1905-1908 rr. Vasyl' Yakovych Protopopov: korotkyy istorychnyy portret. Pivdennyy zakhid. Odesyka. Istoryko-krayeznavchyy naukovyy al'manakh, 25, s. 233-239. [in Ukrainian].

2. Herasymenko, V., 2018. Pavlo Oleksandrovych Zelenyy yak mis'kyy holova Odesy (18981905). Khadzhybeyivs'ki chytannya: materialy Vseukrayins'koyi naukovoyi konferentsiyi z istoriyi Ukrayiny dlya studentiv ta aspirantiv, Odesa, s. 3-8. [in Ukrainian].

3. Herlihi, P., 1999. Odesa: istoriya mista, 1794-1914. Kyiv: Krytyka. [in Ukrainian]. 
4. Honcharuk, T. H., Herasymenko, V. V. \& Zhylenkova, I. M., 2018. Initsiatyvy mis'koho holovy Odesy P. O. Zelenoho na storinkakh «Yzvestyy Odesskoy horodskoy dumy» (1898-1905). Intelihentsiya i vlada. Seriya: Istoriya, 38, s. 214-230. [in Ukrainian].

5. Honcharuk, T., 2020. Do pytannya pro vysvitlennya podiy yevreys'koho pohromu zhovtnya 1905 r. v Odesi na storinkakh mistsevoyi presy (za materialamy hazet «Odesskyy lystok» ta «Odesskye novosty»). Pivdennyy zakhid. Odesyka. Istoryko-krayeznavchyy naukovyy al'manakh, 29, s. 153-162. [in Ukrainian].

6. Derzhavnyy arkhiv Odes'koyi oblasti (Ukrayina). F. 2. Op. 8. Spr. 2394.9 ark. [in Russian].

7. Zlenko, H., 1997. Pavlo Zelenyy - odes'kyy mis'kyy holova i literator. Kyyivs'ka starovyna, 6 [online]. Available at: $<$ http://library.kr.ua/elmuseum/zem/zelenyy/index.html $>$ [Accessed 24 November 2020]. [in Ukrainian]

8. Stanko, V. N. red., 2002. Istoriia Odesy. Odesa: Druk. [in Ukrainian].

9. K zabastovke zheleznodorozhnikh sluzhashchikh, 1905. Odesskyy lystok, 15 oktyabrya. [in Russian].

10. K prekrashcheniyu dvizheniya poyezdov, 1905. Odesskyy lystok, 13 oktyabrya. [in Russian].

11. Malakhov, V. P. \& Stepanenko, B. A., 2004. Odessa, 1900-1920. Lyudi... Sobytiya... Fakty... Odessa: Optimum. [in Russian].

12. Novyy Odesskiy gorodskoy glava, 1897. Odesskiye novosti, 21 fevralya. [in Russian].

13. Odesskyy lystok, 1905, 1 oktyabrya. [in Russian].

14. Odesskyy lystok, 1905, 5 oktyabrya. [in Russian].

15. Odesskyy lystok, 1905, 9 oktyabrya. [in Russian].

16. Odesskyy lystok, 1905, 15 oktyabrya. [in Russian].

17. Odesskyy lystok, 1905, 26 oktyabrya. [in Russian].

18. Odesskyy lystok, 1905, 30 oktyabrya. [in Russian].

19. Odesskiye novosti, 1898, 24 fevralya. [in Russian].

20. Odesskiye novosti, 1905, 28 yanvarya. [in Russian].

21. Odesskiye novosti, 1905, 3 aprelya. [in Russian].

22. Odesskiye novosti, 1905, 20 aprelya. [in Russian].

23. Odesskiye novosti, 1905, 28 aprelya. [in Russian].

24. Odesskiye novosti, 1905, 21 maya. [in Russian].

25. Odesskiye novosti, 1905, 16 iyunya. [in Russian].

26. Odesskiye novosti, 1897, 5 dekabrya. [in Russian].

27. Odesskiye novosti, 1897, 6 dekabrya. [in Russian].

28. Odesskiye novosti, 1897, 13 dekabrya. [in Russian].

29. Odesskiye novosti, 1897, 15 dekabrya. [in Russian].

30. Odesskiye novosti, 1905, 24 dekabrya. [in Russian].

31. Palamarchuk, V., 2017. Mis'kyy holova Petro Adamovych Kryzhanovs'kyy - «kazkovyy prynts, shcho maye rozbudyty splyachu krasunyu Odesu». Pivdennyy zakhid. Odesyka. Istorykokrayeznavchyy naukovyy al'manakh, 23, s. 208-212. [in Ukrainian].

32. S.-L., 1912. Pamyati P. A. Zelenogo. Odesskyy lystok, 22 avgusta. [in Russian].

33. Soveshchaniye predstaviteley odes. Pechati, 1905. Odesskyy lystok, 15 fevralya. [in Russian].

34. Solzhenitsyn, A. I., 2001. Dvesti let vmeste: V 2 vol. Vol. 1. Moscow: Russkiy put'. [online]. Available at: $<$ http://book-online.com.ua/read.php?book=4500 $>$ [Accessed 24 November 2020]. [in Russian].

Отримано: 24.11.2020 p. 
ISSN 2519-2523 (print)

Chornomors'ka mynuvshyna. - 2020. - No.15

DOI: $10.18524 / 2519-2523.2020 .15 .218680$

УДК: 94:314.743(477)"1945/1980"

\title{
VOLODYMYR MOSHYNSKY IN THE UKRAINIAN COSSACK MOVEMENT OF THE XX CENTURY
}

\author{
Olexsandr Muzychko \\ ORCID: https://orcid.org/0000-0002-8019-2254 \\ DSc (History), Associate Professor \\ Odessa I. I. Mechnikov National University \\ 2, Dvoryanska Str., Odessa, 65082, Ukraine \\ sandro06@ukr.net
}

The purpose of this article is to study the participation of Volodymyr Moshynsky (1895-1988) in the Ukrainian Cossack movement, who for some time was a representative of the Odessa center of the Ukrainian revolution of 1917-1921, but the main stage of his life took place in North America in the second half of the twentieth century. The article is based on the use of a wide source base of published narrative sources, the most important of which are the memoirs and works of $V$. Moshinsky. Biographical, prosopographic, historical-genetic methods, as well as a number of generally accepted scientific methods were used to implement the tasks. The historiographical work on the figure of $V$. Moshinsky is narrow and clearly inadequate to the scale of his activity. It is mentioned in a limited number of publications and sometimes in a false context. V. Moshynsky's articles show that he was fully aware of his Cossack ancestral roots and was proud of them. There was a harmonious connection between the facts of his biography and his interests, as he had to work in the interwar period in the area where his wife's ancestors came from the Danube Cossacks. In October 1917, during a confrontation with the Bolsheviks in Moscow, V. Moshinsky became friends with the Amur Cossacks, who almost persuaded him to go with them to the Far East. $V$. Moshinsky received scientific information about the history of the Ukrainian Cossacks at lectures of the leading Odessa Cossack scholar M. Slabchenko. The Cossack trace in V. Moshinsky's biography was most clearly reflected in his activity in the Cossack Ukrainian movement in the USA. In the 1970s, he was one of the leaders, clerk, tent of the Ukrainian Free Cossacks in Denver named after the commander, the first knight of the Iron Cross, Colonel-General Mikhail Omelyanovich-Pavlenko. V. Moshynsky received the rank of Cossack lieutenant colonel and later colonel. The main body of the free Cossack movement in the United States was the magazine "Ukrainian Cossacks", published from the late 1960s to the 1980s. V. Moshinsky was mentioned in the pages of this magazine as a donor to its publication, was the author of a number of articles. The magazine covered the artistic activity of $V$. Moshynsky and his children, with the inclusion of this activity in the Cossack context. In 1974, the magazine published an important and so far unique evidence that the Cossack theme was present in the artist's work - a reproduction of his painting in the mid-1950s "Hetman Mazepa before the Battle of Poltava", kept in Montreal, donated to the Women's Society "Daughters of Ukraine". Thus, in the figure of V. Moshinsky we have one of the most original popularizers of the history of the Ukrainian Cossacks, a Cossackpractitioner and a Cossack-artist, a Cossack-memoirist, whose rich life experience united Ukraine and the diaspora with invisible ties, contributed to the preservation of historical memory not the most popular pages of Cossack history. But these pages are the most important for the modern Odessa region, where the problem of saturation of Bessarabia (as well as Odessa and Odessa region in general) with the Ukrainian worldview and culture is acutely relevant. The author considered the Cossacks within the framework of the national tradition, which combined the 
features of populist and state historiography, which was a typical feature of the North American Ukrainian historiographical tradition.

Key words: Southern Ukraine, Odessa, military, Danube Cossacks, Cossacks study.

Олександр Музичко

ORCID: https://orcid.org/0000-0002-8019-2254

Доктор історичних наук, доцент

Одеський національний університет імені I. I. Мечникова

Вул. Дворянська, 2, Одеса, 65082, Україна

sandro06@ukr.net

\section{ВОЛОДИМИР МОШИНСЬКИЙ В УКРАЇНСЬКОМУ КОЗАЦЬКОМУ РУСІ ХХ СТОЛІтТЯ}

Метою иієї статті є дослідження участі в українському козаџькому русі Володимира Мошинського (1895 - 1988), деякий час представника одеського плацдарму Украӥнської револючії 1917 - 1921 років, але основний етап життя якого відбувся вже у Північній Америчі у другій половині XX cm. У постаті В. Мошинського маємо одного з найбільш своєрідних популяризаторів історії украӥнського козачтва, козака-практика та козакамития, козака-мемуариста, багатий життєвий досвід якого єднав незримими узами Украӥну та діаспору, сприяв збереженню історичної пам'яті про не найпомітніші та не найпопулярніші сторінки козачької історії.

Ключові слова: Південна Украӥна, Одеса, військові, Дунайське козачтво, козакознавство.

У сучасній історіографії можна зустріти непоодинокі тези про, мовляв, «застарілість» фактологічної історії та необхідність до зосередження виключно на широких теоретичних, історіософсько-соціологічних узагальненнях. Таким чином, в українські реалії, на жаль, як і багато в іншому, не виважено вкидаються справді слушні для США тенденції тамтешньої історіографії. Для України ж, яка тривалий час фактично була позбавлена власної історіографії і на сьогодні актуальними $\epsilon$ дослідження, що реконструюють на конкретній документальній базі (не боїмося це пов'язати 3 традиціями доброго, старого, позитівізму) частинки колись штучно розбитої мозаїки української історії, при чому найбільш важливими є ті ії аспекти, що відображають історію боротьби за національне «Я», державність, національні світоглядні цінності. Значною мірою ці риси були втілені у новокозацькому, вільнокозацькому русі спочатку на території України, а потім української еміграції/діаспори XX ст. Цей рух тісно переплітався з загальним мілітарним рухом українців, діями українських військових частин УНР та ЗУНР в роки Української революції 1917 - 1921 рр. Персональний вимір історії мілітарного українського руху, зокрема, вільнокозацького, й його еміграційно-діаспорні аспекти, ретельно вивчаються в Україні в останні десятиліття. Варто наголосити, що тривалий час, в умовах російсько-комуністичної окупації України у другій половині ХХ ст., саме еміграція/діаспора були ареалом збереження історичної пам'яті українців, збирання відомостей, публікації документів, аналітики, що було започатковано у міжвоєнній Галичині та Волині.

Метою цієї статті є дослідження участі в українському козацькому русі Володимира Мошинського (1895 - 1988), деякий час представника одеського плацдарму Української революції 1917 - 1921 рр., але основний етап життя якого відбувся вже у 
Північній Америці у другій половині XX ст. Тривале та насичене життя цього непересічного діяча варте комплексного дослідження, чим ми i займаємося i реалізуємо свій доробок у серії подальших статей, але у цій статті зосередимося на козакознавчому аспекті.

Стаття грунтується на використанні широкої джерельної бази опублікованих наративних джерел, найважливішими з яких є мемуари та праці В. Мошинського. Для реалізації завдань використано біографічний, просопографічний, історико-генетичний методи, а також низку загальноприйнятих наукових методів.

Історіографічний доробок щодо постаті В. Мошинського $\epsilon$ вузький i явно неадекватний масштабам його діяльності. Широка громадськість не дізнається про нього ані з діаспорної «Енциклопедії українознавства», ані з новітньої «Енциклопедії історії України». Єдиним поширеним джерелом інформації, де $\epsilon$ стаття про В. Мошинського, є «Енциклопедія сучасної України», де надано основні віхи його біографії. У низці публікацій у діаспорі та в Україні про В. Мошинського згадано передусім як про митця [9, с. 66-67; 26, с. 166; 28]. Основи вивчення В. Мошинського як військового діяча заклав Я. Тинченко, хоча йдеться тільки про згадку дуже поодиноких фактів [27, с. 330, 337].

Не обійшлося, як це часто буває щодо маловідомих постатей, і без трагікомічних парадоксів. Маємо на увазі велику статтю львівського філолога Миколи Крупача, в якій він розгорнув складні реконструкції, в результаті яких «переписав» статті В. Мошинського у варшавській українській газеті «Син України» (до того ж прямо підписані саме «В. Мошинський»!) на авторство Є. Маланюка, який, мовляв, використав прізвище В. Мошинський в якості одного зі своїх псевдонімів [10, с. 3637]. Таким чином, факти біографії В. Мошинського М. Крупач на підставі своїх хибних висновків відніс до біографії Є. Маланюка. Причина цього прикрого випадку банальна, про що повідомив сам автор - він просто не знав про існування постаті В. Мошинського (як тут не згадати і про те, що все ж таки філологам не слід обходитися без істориків у своїй пошуковій діяльності, бо без істориків неможливо наблизитись до адекватного пізнання історії). При тому нам не вдалося виявити в історіографії згадок про козакознавчі аспекти у житті В. Мошинського, що $\epsilon$ предметом розгляду цієї статті.

Козакознавчий аспект тісно вплетений у загальне мереживо життєвого шляху В. Мошинського. Тому намітимо основні контури його ще фактично ненаписаної біографії.

В нас є мінімум даних про перший етап життя В. Мошинського. Народився він 18 червня 1895 р. в селі Турбові на Поділлі (сучасна Вінницька область) у родині Миколи Мошинського та Марії Мефодіївни з роду Богуславських [4]. I батько, і мати походили з родин священиків. Мав брата Миколу, який воював на фронтах Першої світової війни та помер у 1918 р., та трьох сестер, що згодом мешкали в Одесі. Одна 3 них, Лідія, брала участь в українському національному русі, була директоркою першої української школи імені Івана Франка. В. Мошинський закінчив Московську гімназію та Олексіївську військову школу.

Перший, i, слід думати, найнасиченіший, період його життя припав на добу Першої світової війни, Російської та Української революцій. Він служив у 95-му Красноярському полку на Волині. Від весни 1917 р. служив у званні старшини. Був нагороджений солдатським хрестом Св. Георгія [17]. У жовтні-листопаді 1917 р. він був активним учасником боротьби проти більшовиків у Москві на боці Тимчасового 
уряду проти більшовиків. Отже, в Одесі В. Мошинський був прикладом вояка, що мав досвід антибільшовицької боротьби у самому «лігві».

Наприкінці 1917 р. В. Мошинський демобілізувався та приїхав до міста Сквира. У червні 1918 р. - квітні 1920 р. тривав одеський період діяльності В. Мошинського. Мешкав він на Канатній вулиці на розі Пантелеймонівській (дім Віта). Брав участь у теософському гуртку. Працював чорноробом в Одеському залізничному депо з метою поширення української пропаганди до вересня 1918 року. Потім вступив у лави 14-ї стрілецького полку четвертої Залізної бригади, в сотню сотника Вишневського. Охороняв склади. Паралельно навчався у Театральній українській студії, брав участь в організації українських театральних вистав [21]. В. Мошинський був одним 3 активних учасників Української революції в Одесі, помічником адмірала М. Остроградського, організатором та членом української військової організації Одеси. На початку грудня він увійшов до 14-ої бригади Української Галицької армії, що розташовувалась в касарнях на Грецькій вулиці.

У 1920 р. В. Мошинському вдалося вибратися з окупованої комуністами Одеси, переїхати до польського Тарнува та зустрітися з С. Петлюрою. У 1921 - 1922 рр. В. Мошинський діяв у складі надзвичайної дипломатичної місії УНР у Румунії у званні молодшого старшини для зв'язку відділу повстанських організацій генерального штабу. Судячи з його листа до шефа військової секції місії генерала С. Дельвіга, сотник В. Мошинський мав з території Молдови потрапити до Одеси в якості розвідника, але на заваді став корупційний скандал у середовищі причетних до цієї справи румунських та українських уповноважених [3, с. 146-147].

Однак на території тогочасної Румунської держави, в Ізмаїлі, він залишився надовго, аж до 1944 р., живучи за нансенівським паспортом. Він розмальовував бессарабські та румунські церкви, меморіали. Наприкінці життя він тепло згадував про ці роки: «Південь Бессарабії - милий моєму серцеві край! Це край, у якому я зазнав щастя любові, де одружився 3 коханою дівчиною, прожив 24 роки молодого життя й де з дружиною виростили на користь Україні своїх трьох дітей. Не дивлячись на утиски румунської влади... той край залишається в моїх споминах найкращий. Тут, у США, з прекрасної далечини, згадуються мені моменти моєї тодішньої творчості 3 якоюсь душевною радістю, а моменти невигод i неприємностей, якось затушовуються, зникають в темряві років» [16, с. 9].

У післявоєнний період мешкав в Австрії. У 1950 р. В. Мошинський переїхав до Монреалю. Тут він був активним учасником «Союзу бувших українських вояків у Канаді», був нагороджений Хрестом Симона Петлюри за участь у збройній боротьбі за державність та Воєнним хрестом [27, с. 330, 337].

«Тут, у США, я зміг ширше розправити свої крила і свої думки - мрії мистця багато легше мені перетворити в дійсність, в образи!», - згадував він [16, с. 9].

Він розмалював 7 церков. Головним чином у штаті Мен. Виконав понад сотню портретів (югославського короля Александра, американця Ловелла Томаса на замовлення Денверського університету). Створений ним портрет митрополита А. Шептицького був придбаний для австрійського замку. В. Мошинський був іконописцем у рідкісній техніці малювання ікон на золотому чеканному тлі. Його пензлю належать такі картини як «Св. Володимир», «Свята Родина», «Архангел Михаїл», «Хрещення України», краєвиди [1][12]. У 1986 р. отримав приз «Тһе American by Choise Award». Цю нагороду надавали щороку двом найбільш значимим мешканцям штату Колорадо з числа натуралізованих громадян в день громадянства 17 вересня за їхній внесок у культурний та суспільний розвиток штату. 
В. Мошинський був першим митцем, хто отримав цю нагороду в іiї історії вручень, бо до нього її отримували лише громадські та суспільні діячі [13].

Передусім був оцінений внесок митця у популяризацію історії штату Колорадо. У день 88-річчя В. Мошинський отримав привітання від президента США Р. Рейгана та його дружини Ненсі [24]. В ювілейній статті до 70-річчя митця сучасник зазначив, що у свої 70 років він «виглядає як справжній козарлюга, молодий духом і тілом» [11, с. 28]. Козацький слід виразно відбився не тільки у поставі митця, але й загалом в його життєвому шляху.

Вже на схилі років, у 1974 р., В. Мошинський в окремій статті висвітлив свій козацький родовід [20]. I хоча не навів точних даних, показовий вже сам факт цієї саморефлексії митця. Він згадував, що на запитання про родовід, його батько розповідав йому, що, згідно з родинними переказами, Мошинські ведуть свій родовід від козака Мошни $з$ містечка Мошна, хоча сам батько народився вже у родині священика на Київщині. Намагаючись поглибити козацький аспект своєї біографії, В. Мошинський згадав про відповідні коріння своєї дружини - ізмаїльчанки Лариси Захарівни Чайківської. ІІЇ батько, священик Захарій, розповідав про те, що колись на Дунайську Січ прийшло три брати, один з яких був дідом Захарія, а його батько теж певний час був січовиком-задунайцем, а потім - Буджацького (Дунайського) козацького війська, що проіснувало до 1868 р.

Ці тези В. Мошинського підтверджуються нотатками його сина Юрія про зустріч у Франції з братом його матері Іваном. Юрій зауважив, що незважаючи на довгі роки еміграції, «Все таки старокозацька кров у ньому не застигла, і він часто згадує свого діда та прадіда, що були одними з ранніх емігрантів з України на Задунайську Січ» $[23$, c. 148,176$]$.

У жовтні 1917 р. у Москві під час протистояння з більшовиками В. Мошинський приятелював 3 приамурськими козаками, які ледве не умовили його поїхати з ними на Далекий Схід. У 1918 р. В. Мошинський отримав наукову інформацію про історію українського козацтва на лекціях провідного одеського козакознавця Михайла Слабченка, свого професора у театральній студії імені Марка Кропивницького в Одесі [21, с. 1255].Найвиразніше козацький слід у біографії В. Мошинського відбився в його діяльності у козацькому українському русі у США. У 1970-х роках він був одним із провідників, писарем, куреня українського вільного козацтва в Денвері імені командарма, першого лицаря залізного хреста, генерал-полковника Михайла Омеляновича-Павленка. В. Мошинський отримав звання козацького підполковника та згодом полковника. У звіті про діяльність осередку колишній сотник армії УНР висловив думку, що українське вільне козацтво є станова, парамілітарна, не політична і не партійна організація, що має єднатися навколо боротьби за реалізації величної ідеї Української Самостійної Соборної Держави. «Мусимо працювати для цієї ідеї, підтримувати дух цієї ідеї, за яку боролися ми в Визвольних змаганнях, за яку проливали кров наші брати і сестри, за яку борються і тепер одчайдухи на наших рідних землях... Слава високим ідеям Козацтва! Слава Українському Вільному козацтву!», - наголошував він [19, с. 67].

Основним органом вільнокозачого руху у США був часопис «Українське козацтво», що видавався 3 кінця 1960-х - у 1980-х роках [2]. В. Мошинський вказувався на сторінках цього часопису як жертводавець на його видання. У 1979 р. у листі до редакції він писав: «журнал, Вами створений, займає почесне місце в цілій українській періодиці, це вже відмічено і це не є комплімент, а правда...» [18, с. 40]. 
У часописі висвітлювалась мистецька діяльність В. Мошинського та його дітей, 3 внесенням цієї діяльності у козацький контекст [8].

У 1974 р. часопис опублікував важливе і поки що унікальне свідчення про те, що козацька тематика була присутня у творчості митця - репродукцію його картини середини 1950-х років «Гетьман Мазепа перед Полтавським боєм», що зберігалася у Монреалі, подарована свого часу Жіночому товариству «Доньки України» [5].Окрім двох вже згаданих статей (про козацький родовід родини та звіт про діяльність куреня українського вільного козацтва) у часописі було оприлюднено ще дві статті В. Мошинського. У 1982 р. В. Мошинський надрукував фрагмент своїх спогадів про один 3 найяскравіших епізодів в його житті - участь у засіданнях першого українського військового з’їзду 1917 р. [17]. Проте, козацької тематики у цій статі не було.

Тому значно важливішою є його попередня велика публікація, 1973 р., про задунайських козаків, Задунайську Січ [15]. Відкривав працю промовистий епіграфпосвята священику Захарію Чайківському, його дітям Миколі та Івану та своїй дружині Ларисі - нащадкам дунайських козаків. Автор грунтовно підійшов до висвітлення питання, навівши багато фактів, чим сприяв популяризації не типової для діаспорної історіографії тематики.

Але цінність статті полягала не у наведенні загальновідомих і на той час і тим більше нині даних, або новій методології чи історіософії (автор, звичайно, розглядав козаків в рамках націєтворчої традиції, що поєднувала риси народницької та державницької історіографії, що було типовою рисою північноамериканської української історіографічної традиції), а у фіксації автобіографічної інформації, передусім у жанрі усної історії, що є свідченням про циркулювання історичної пам'яті про козацтво у цьому регіоні. В. Мошинський згадав про своє перебування у цій місцевості на зламі 1930-х - 1940-х років, докладно описав свої бесіди зі старожилами, дунайцями, нащадками козаків, тим самим продовживши традицію усної історії щодо цього питання, яку започаткували, зокрема, одеські історики кінця XIX - початку XX ст. [6; 7; 25]. Завершив свою статтю В. Мошинський промовистим пасажем, що може бути використаний i зараз у відповідних наративах: «Так, починаючи 3 кінця 16-го і майже до кінця 19-го століття українське козацтво густо поливало своєю кров'ю землі навколо гирла Дунаю, що ніс лицарську козачу кров у наше Сорне море... Три століття боротьби, звитяжства і слави!» [15, с. 16]У тому ж 1973 р. в одному 3 провідних часописів української діаспори ця стаття В. Мошинського, хоч і під такою самою назвою, була видана у значно більш доповненому вигляді [14]. Зокрема, автор більше уваги приділив участі козаків у штурмі Ізмаїлу 1790 р. Також автор мав можливість розширити мемуарну частину і саме про своє перебування в Ізмаїлі та Кілії у міжвоєнний період. У 1943 р. В. Мошинський виконав доручення намалювати чотири ікони у каплиці на цвинтарі невідомим воякам Першої світової війни в Ізмаїлі.

Показовим є в контексті нашої теми спогад В. Мошинського про мотивацію своєї праці: «я відчував велику приємність, що мені доручено розмалювати каплицюпам'ятник, бо цей пам'ятник був не тільки пам'ятником воякам, що загинули у першу світову війну, а й символічним пам'ятником «крови», яку колись пролляли на валах $\mathrm{i}$ мурах Ізмаїльської фортеці також запорожці; тут була й українська кров, хоч i проллята за чужу справу» [14, с. 1330]. Ілюструючи цю тезу, митець згадав про дії козаків у цій місцевості у часи Наливайка. Більш докладно були висвітлені обставини виникнення Задунайської Січі та побуту задунайців. Деякі автобіографічні 
зауваження пересипані художньою уявою митця. Так, описуючи своє плавання по зимовому Дунаю поблизу Ізмаїла, В. Мошинський згадував, що йому тоді спали на думку історичні події 1790 р.: «Тоді запорозькі козаки з флотилії де Рібаса нишком пливли по Дунаю уночі, робили розвідку, іноді натрапляючи на сильні стежі турків на каюках, зчиняли з ними бій. Це було давно, а здавалося, начебто вчора! Може і тоді йшла крига, може й тоді запорожці чули той шерех криг...» [14, с. 1342]. Втім, якщо стаття в «Українському козацтві» мала оптимістичне закінчення, то у цій статті останнє речення В. Мошинського виглядало значно більш песимістично-критично: «Але, на жаль, всі ті звитяги, всі ті жертви були, переважно, на користь не Україні, а їі ворогам - москалям або туркам!».

У переробленому вигляді стаття В. Мошинського про дунайське козацтво була надрукована у 1980 р. в іншому американському українському часописі. Щоправда, найцінніші фрагменти своєї публікації він саме звів до мінімуму [16].

В обох статтях В. Мошинський згадував про липован та їх взаємини 3 дунайськими козаками. В окремій публікації він справедливо виправив помилкове твердження про те, що липовани, це, мовляв, є різновид українців [22]. Ця стаття, як $\mathrm{i}$ стаття 1973 р. у часописі «Українське козацтво», насичена цінними для історика липован та Українського Придунав'я автобіографічними деталями, що ілюстрували думку автора про абсолютну нетотожність і навіть часто-густо ворожість один до одного липован та українців, зокрема, козаків.

Отже, у постаті В. Мошинського маємо одного 3 найбільш своєрідних популяризаторів історії українського козацтва, козака-практика та козака-митця, козакамемуариста, багатий життєвий досвід якого єднав незримими узами Україну та діаспору, сприяв збереженню історичної пам'яті про не найпомітніші та не найпопулярніші сторінки козацької історії. Але саме ці сторінки є найважливішими для сучасної Одещини, де гостро актуальною є проблема насичення Бессарабії (як, втім, й Одеси та Одещини загалом) українським світоглядом, культурою. Життєвий досвід та тексти маестро-Мошинського, як називали його сучасники, є чудовим євшан-зіллям.

\section{Джерела та література:}

1. Биковський Л. Десять років науково-організаційної праці на Заході США (Денверська група УВАН) / Л. Биковський // Визвольний шлях. - 1966. - № 7-8. - С. 957-966.

2. Богуславський О. В. Журнал «Українське Козацтво» як речник військової думки повоєнної української еміграції / О. В. Богуславський // Поліграфія і видавнича справа : наук.-техн. зб.- 2002. - № 39. - С. 82-86.

3. Власенко В. М. Документи і матеріали надзвичайної дипломатичної місії УНР у Румунії (1919-1923 рр.) / В. М. Власенко // Пам’ятки: археографічний щорічник. - К., 2008. - Т. 8. С. 129-160.

4. Жила В. Справжнє мистецьке зусилля не пропадає (До 92-річчя 3 дня народження митця В. Мошинського) / В. Жила // Свобода. - 1987. - 13 лютого.

5. 3 багатого дорібку підполк. УК В. Мошинського // Українське козацтво. - 1974. - Ч. 1. - С. 17.

6. Иванов П. Иванов П.А. А. К истории Запорожских казаков после уничтожения Сечи / П. А. Иванов // Записки Одесского общества истории и древностей (ЗООИД). - 1904. - Т. 25. (Протоколы). - С. 20-40

7. Иванов П. А. Черноморские казаки в Слободзее / П. А. Иванов // ЗООИД.- 1902. T. XXIV. - C. 81-91.

8. Іващук В. Мистецькі осяги козацької родини Мошинських / В. Іващук // Українське козацтво. - 1971. - Ч. 4. - С. 40-41.

9. Кейван І. Українські мистці поза Батьківщиною / І. Кейван. - Едмонтон, 1996. - 227 с. 
10. Крупач М. Пошуки дотаборових публікацій Євгена Маланюка (1916-1917 та 1920 років) / М. Крупач // Українське літературознавство. - 2013. - Вип. 77. - С. 3-44.

11. Крупський К. Родина мистців / К. Крупський // Овид. - 1965. - № 4. - С. 25-28.

12. Л. Б. Денверська група УВАН / Л. Б.// Українські вісті. - 1969. - 13-20 квітня. - С. 3.

13. Михайленко О. Українець одержав нагороду «Американець за вибором»/ О. Михайленко // Свобода. - 1987. - 28 січня.

14. Мошинський В. Дунайське козацтво / В. Мошинський // Визвольний шлях. - 1973. - Кн. 11/12. - С. 1324-1346.

15. Мошинський В. Дунайське козацтво / В. Мошинський // Українське козацтво. - 1973. Ч. 3. - С. 9-16.

16. Мошинський В. Дунайське козацтво / В. Мошинський // Нові дні. - 1980. - Квітень. C. 9-12.

17. Мошинський В. 3 далекого минулого (Спогад) / В. Мошинський // Українське козацтво. - 1982. - Ч. 1. - С. 50-57.

18. Мошинський В. Лист до редакції / В. Мошинський // Українське козацтво. - 1979. - Ч. 5. - C. 40 .

19. Мошинський В. 3 діяльності куреня УВК Ч. 16 ім. командарма, першого лицаря залізного хреста, генерал-полковника Михайла Омеляновича-Павленка, в Денвері / В. Мошинський // 1980. - № 1-3. - С. 66-69.

20. Мошинський В. Родинні зв'язки Мошинських і Чайківських 3 козацтвом / В. Мошинський // Українське козацтво. - 1974. - Ч. 2. - С. 16-17.

21. Мошинський В. Український державний театр ім. Т. Шевченка в Одесі й театральна студія ім. М. Кропивницького: (зі споминів про Одесу) / В. Мошинський // Визвольний шлях. - 1966. - Кн. 11. - С.1247-1262.

22. Мошинський В. Чи липовани - це українці? (до історії поселення Південної Бесарабії). / В. Мошинський. - Нью-Йорк, 1955. - 8 с.

23. Мошинський Ю. У світі мистецьких чарів. Враження з подорожі. / Ю. Мошинський. Чикаго, 1963. - $326 \mathrm{c.}$

24. Олінкевич-Колодій А. Вісті з Денверу / А. Олінкевич-Колодій // Свобода. - 1983. 21 липня.

25. Петлюра С. В. Рец. на: Иванов П.А. К истории Запорожских казаков после уничтожения Сечи / С. В. Петлюра // Записки наукового товариства ім. Т. Шевченка. - 1905. - Т. 63 Бібліографія. - С. 22-23.

26. Тимків Б. М. Мистецтво України та діаспори: дереворізьба сакральна й ужиткова / Б. М. Тимків. - Івано-Франківськ: Нова Зоря, 2009. - 206 с.

27. Тинченко Я. Офіцерський корпус Армії Української Народної Республіки (1917-1921) / Я. Тинченко. - Київ : Темпора, 2011. - Кн. 2. -422 с.

28. Трембіцький А. М. Часопис «Нотатки 3 мистецтва» (Філадельфія) об'єднання мистців українців в Америці про життєві шляхи і творчу діяльність мистців-подолян / А. М. Трембіцький // Освіта, наука і культура на Поділлі. - 2014. - Т. 21. - С. 234-256.

\section{References:}

1. Bykovs'kyy, L., 1966. Desyat' rokiv naukovo-orhanizatsiynoyi pratsi na Zakhodi SShA (Denvers'ka hrupa UVAN). Vyzvol'nyy shlyakh, 7-8, pp. 957 - 966.

2. Bohuslavs'kyy, O. V., 2002. Zhurnal «Ukrayins'ke Kozatstvo» yak rechnyk viys'kovoyi dumky povoyennoyi ukrayins'koyi emihratsiyi. Polihrafiya $i$ vydavnycha sprava : nauk.-tekhn. zb., 39, pp. 82-86.

3. Vlasenko, V. M., 2008. Dokumenty i materialy nadzvychaynoyi dyplomatychnoyi misiyi UNR u Rumuniyi (1919-1923 rr.). Pam"yatky: arkheohrafichnyy shchorichnyk, 8., pp. 129-160.

4. Zhyla, V., 1987. Spravzhnye mystets'ke zusyllya ne propadaye (Do 92-richchya z dnya narodzhennya myttsya V. Moshyns'koho). Svoboda, 13 lyutoho.

5. Z bahatoho doribku pidpolk. UK V. Moshyns'koho, 1974. Ukrayins'ke kozatstvo, 1, p. 17. 
6. Yvanov, P. A., 1902. Chernomorskye kazaky v Slobodzee. Zapysky Odesskoho obshchestva ystoryy y drevnostey, XXIV, pp. 81-91.

7. Yvanov, P. A., 1904. K ystoryy Zaporozhskykh kazakov posle unychtozhenyya Sechy. Zapysky Odesskoho obshchestva ystoryy y drevnostey, XXV (Protokoly), pp. 20-40.

8. Ivashchuk, V., 1971. Mystets'ki osyahy kozats'koyi rodyny Moshyns'kykh. Ukrayins'ke kozatstvo, 4, pp. 40-41.

9. Keyvan, I., 1996. Ukrayins'ki mysttsi poza Bat'kivshchynoyu. Edmonton.

10. Krupach, M., 2013. Poshuky dotaborovykh publikatsiy Yevhena Malanyuka (1916-1917 ta 1920 rokiv). Ukrayins'ke literaturoznavstvo, 77, pp. 3-44.

11. Krups'kyy, K., 1965. Rodyna mysttsiv. Ovyd, 4, pp. 25-28.

12. L.B., 1969. Denvers'ka hrupa UVAN. Ukrayins'ki visti, 13-20 kvitnya, p. 3.

13. Mykhaylenko, O., 1987. Ukrayinets' oderzhav nahorodu «Amerykanets' za vyborom». Svoboda, 28 sichnya.

14. Moshyns'kyy, V., 1973. Dunays'ke kozatstvo. Vyzvol'nyy shlyakh, 11/12, pp. 1324-1346.

15. Moshyns'kyy, V., 1973. Dunays'ke kozatstvo. Ukrayins'ke kozatstvo, 3, pp. 9-16.

16. Moshyns'kyy, V., 1980. Dunays'ke kozatstvo. Novi dni, kviten', pp. 9 - 12.

17.Moshyns'kyy, V., 1982. Z dalekoho mynuloho (Spohad). Ukrayins'ke kozatstvo, 1, pp. 50-57.

18. Moshyns'kyy, V., 1979. Lyst do redaktsiyi. Ukrayins'ke kozatstvo, 5, p. 40.

19. Moshyns'kyy, V., 1980. Z diyal'nosti kurenya UVK Ch. 16 im. Komandarma, pershoho lytsarya zaliznoho khresta, heneral-polkovnyka Mykhayla Omelyanovycha-Pavlenka, v Denveri. Ukrayins'ke kozatstvo, 1-3, pp. 66-69.

20. Moshyns'kyy, V., 1974. Rodynni zv"yazky Moshyns'kykh i Chaykivs'kykh z kozatstvom. Ukrayins'ke kozatstvo, 2, pp. 16-17.

21. Moshyns'kyy, V., 1966. Ukrayins'kyy derzhavnyy teatr im. T. Shevchenka v Odesi y teatral'na studiya im. M. Kropyvnyts'koho: (Zi spomyniv pro Odesu). Vyzvol'nyy shlyakh, 11, pp.1247-1262.

22. Moshyns'kyy, V., 1955. Chy lypovany - tse ukrayintsi? (do istoriyi poselennya Pivdennoyi Besarabiyi). N'yu-York.

23. Moshyns'kyy, Yu., 1963. U sviti mystets'kykh chariv. Vrazhennya z podorozhi. Chykaho.

24. Olinkevych-Kolodiy, A., 1983. Visti z Denveru. Svoboda, 21 lypnya.

25. Petlyura, S. V., 1905. Rets. na: Yvanov P.A. K ystoryy Zaporozhskykh kazakov posle unychtozhenyya Sechy. Zapysky naukovoho tovarystva im. T. Shevchenka, 63 (Bibliohrafiya), pp. $22-23$.

26. Tymkiv, B. M., 2009. Mystetstvo Ukrayiny ta diaspory: derevoriz'ba sakral'na y uzhytkova. Ivano-Frankivs'k: Nova Zorya, $206 \mathrm{p}$.

27. Tynchenko, Ya., 2011. Ofitsers'kyy korpus Armiyi Ukrayins'koyi Narodnoyi Respubliky (1917-1921), Vol. 2. Kyiv: Tempora.

28. Trembits'kyy, A. M., 2014. Chasopys «Notatky z mystetstva» (Filadel'fiya) ob"yednannya mysttsiv ukrayintsiv v Amerytsi pro zhyttyevi shlyakhy i tvorchu diyal'nist' mysttsiv-podolyan. Osvita, nauka i kul'tura na Podilli, 21, pp. 234-256.

Отримано: 24.11.2020 p. 
ISSN 2519-2523 (print)

Chornomors'ka mynuvshyna. - 2020. - No.15

DOI: $10.18524 / 2519-2523.2020 .15 .218681$

УДК 94(71=161.2)

\title{
SOCIO-CULTURAL MISSION OF THE CANADIAN UKRAINIAN CULTURAL AND EDUCATIONAL CENTER «OSEREDOK» (second quarter of 20th - beginning of 21st century)
}

\author{
Anatoliy Bodrug \\ ORCID: https://orcid.org/0000-0001-6718-4957 \\ Post-graduate student \\ of the Department of History of Ukraine \\ Odessa I. I. Mechnikov National University \\ 2, Dvoryanska Str., Odessa, 65082, Ukraine \\ metall.feniks@yandex.ua
}

The purpose of this article is to consider the activities of the Ukrainian Cultural and Educational Center "Oseredok» and the theoretical justification of its contribution to the collection, research, preservation and exhibition of historical, cultural and spiritual heritage of the Ukrainian diaspora in Canada. "Oseredok» became not only a model of Ukrainian studies education, but also an important center for the development of Ukrainian-Canadian relations, and also influenced the development of Canadian culture in general. To achieve this goal, the necessary number of sources and historiographical literature touched on various aspects of the problem were examined. Such general historical scientific research methods as historical-genetic, historical-comparative and historical-typological were used.

The relevance of this study is related to the modern national-cultural movement, which is embodied in the activities of organizations, art, educational and scientific centers, the introduction of new Ukrainian festivals, the study of previously classified, archival documents. Some aspects of this problem were revealed in the works of such researchers as: Jus O. V., Matyash I. B., Solonskaya N. G. and Priymak T. M. However, in our opinion, the monument protection and sociocultural activities of the Ukrainian Cultural and Educational Center «Oseredok» is worth more indepth research.

Thus, the Ukrainian Cultural and Educational Center "Oseredok» was the unifying force that brought together under one cultural cover Ukrainians with different religious beliefs, political views and values. The founders and patrons of the "Oseredok» were prominent Ukrainian figures: O. Koshetz, T. Koshetz, P. Matsenko, M. Mandryka, T. Pavlychenko, P. Yuzyk, V. Kossar, M. Marunchak, J. Rudnytsky and others. For 76 years, Oseredok has become the guarantor of the collective memory of the Ukrainian people. Even the house of the organization, formerly the House of the Bible Society, has great spiritual power, which contributes to a noble socio-cultural mission. The versatility of the Center's activities, which includes archival, library, museum, educational and publishing work, is striking. The archive of the organization has the largest collection of documents, memoirs, photographs, maps in Canada, which covers the period of 16th - 20th centuries. Valuable are the documents and memoirs of I. M. Bobersky, E. M. Konovalets, the Koshets family, as well as a monument of the 18th century - Irmola by Georgy Tyapetsky. "Oseredok» has a rich library collection of more than 40 thousand volumes and 10 thousand periodicals. Nomocanon of the 17th century is a very rare book. The collection of the museum of the Center consists of 8 thousand exhibits, which includes objects of decorative and applied arts, musical instruments, church utensils, personal belongings. In the collections of the art gallery you can see paintings by more than 30 Ukrainian artists from realism to avant-garde. The Center has higher education courses that have brought up many prominent Ukrainians. The publishing activity 
of the center not only contributed to the development of science and art, but also acquainted the whole world with the rich Ukrainian culture. Thus, Ukrainian Cultural and Educational Centre «Oseredok» is a model of cultural preservation organization.

Key words: Ukrainian diaspora of Canada, The Ukrainian Cultural and Educational Center «Oseredok», The Ukrainian National Federation of Canada (U.N.F.), Ukrainian studies, archival studies.

\section{СОЦІОКУЛЬУРНА МІСІЯ КАНАДСЬКОГО ЦЕНТРУ УКРАЇНСЬКОЇ КУЛЬТУРИ ТА ОСВІТИ «ОСЕРЕДОК» (друга чверть ХХ - початок XXI ст.)}

Мета даної наукової статті полягає у розгляді діяльності Центру української культури та освіти «Осередок» та теоретичного обтрунтування його внеску у процеси збирання, дослідження, збереження та подальшого експозиціонування історичної, культурної та духовної спадщини украӥнської діаспори Канади. Саме об'єднання зусиль суспільно-політичних організачій та відомих громадських діячів заклало важливу підвалину в збереження нації в тяжких воєнних та соціальних умовах перебування на чужині. «Осередок» став не лише взірием украӥнознавчої освіти, але і важливим центром розбудови українсько-канадських відносин, а також загалом вплинув на розвиток канадської культури. Для досягнення зазначеної мети було залучено необхідну кількість джерел та історіографічної літератури, які торкались різних аспектів проблеми. Автором було застосовано такі загальноісторичні наукові методи дослідження, як історико-генетичний, історико-порівняльний та історико-типологічний. У межах даного дослідження було надано генезис Центру украӥнської культури та освіти «Осередок», розглянуто основні підрозділи, напрямки роботи, сочіокультурні програми, типологізовано найважливіші колекції й архівні документи, а також проаналізовано їх історико-культурну иінність. Окрема увага присвячена аналізу ролі засновників, збирачів колекцій та меценатів $у$ розвитку «Осередку». Вперше здійснена спроба узагальнення різних аспектів порушеної проблеми.

Ключові слова: украӥнська діаспора Канади, Центр украӥнської культури та освіти «Осередок», Украӥнське Національне Об'єднання (УНО), украӥнознавство, архівознавство.

«Осередок - місце для всіх українців, де для одної дорогої всіх цілі можуть працювати всі разом, без поділів за переконанням і релігійною приналежності, а як діти одного народу, який має одну велику, людяну й героїчну історію та одну красну й своєрідну культуру» [7, с. 1] - відзначав талановитий поет, видатний науковець, громадсько-політичний та культурний діяч, голова Центру української культури та освіти «Осередок» у 1950-1958 рр. Тиміш Павличенко. У даний вислів вкладено глибокий культурологічний та етнополітологічний зміст, основні аспекти яких чітко прослідковуються в історичному процесі українського народу. I дійсно, у вирі бурхливих революційних подій або у роки тяжкого воєнного лихоліття збереження кожної нації залежало від колективного усвідомлення важливості об'єднання народу в єдину та цілісну громаду. Історичний досвід свідчить, що ідеологічний або релігійний розбрат викликав культурний занепад, етнічну асиміляцію та зникнення 
цілих держав з політичної карти світу. Так, у X-XIII ст. воєнні кампанії русичів проти степових кочівників були успішними лише тоді, коли слов'янські народи виступали об'єднаним військом. Проте феодальна роздробленість та міжусобні війни не дали змогу вистояти у XIII ст. перед татаро-монгольською навалою, що призвело до остаточного занепаду могутньої Київської Русі. В XV-XVIII ст. на чолі збереження національної культури виступило славне українське козацтво, яке відрізнялось воєнною доблестю, оригінальною стратегією та чудовою злагодженістю. Але вже у другій пол. XVII ст. в козацькій громаді почав набирати обертів релігійно-політичний розбрат та сепаратистські тенденції, які стали причиною громадянської війни. Наслідком Руїни став поділ України між сусідніми державами Річчю Посполитою та Московією. 3 кінця XVIII - XIX ст. зароджується новий соціокультурний феномен український національний рух, який заклав основу у майбутню українську революцію та створення УНР. Важливою складовою данного руху було відродження національної культури, збір та обробка фольклорних пам'яток, розвиток мистецтва, відкриття цілої низки організацій, які проводили значну громадську, культурну, релігійну та політичну роботу, спрямовану на пропаганду патріотичної думки. Після фактичної поразки Директорії УНР у 1920 р. внаслідок непослідовних внутрішньо- та зовнішньополітичних рішень, розбіжностей у поглядах урядовців, втрати довіри 3 боку населення, розгрому у війні з більшовиками, діяльність багатьох українських націоналістичних організацій не припинили свою роботу, а реорганізувались та змінили місця своєї дислокації. Майже напередодні Другої світової війни 18 січня 1939 р. колишніми членами УНР та громадсько-культурними діячами Підкарпатської Русі у м. Хуст було засновано нову політичну організацію - Українське національне об'єднання (УНО). Ідеологічно і політично черпала ця організація свої соки 3 українського націоналістичного руху, який очолював полковник Евген Коновалець [3, c. 136]. Головною метою організації стало відстоювання інтересів українського народу, збереження історичної та культурної ідентичності у Карпатській Україні, як автономному краї Чехословацької республіки. Проте у березні 1939 р. Закарпаття було анексовано Угорським королівством, що стало причиною згортання діяльності УНО на цій території, що, однак, не означало остаточного припинення іiі роботи. Діяльність організації була продовжена за океаном, а саме на території Канади, де перший підрозділ УНО було відкрито в Едмонтоні ще в 1932 р. У 1943 р. філію УНО було відкрито в столиці провінції Манітоба - м. Вінніпег. Саме представники Українського національного об'єднання, а також видатні культурні, наукові, громадські, політичні діячі та всі небайдужі члени української діаспори згуртувались довкола націєоб'єднуючої мети і виступили засновниками та фундаторами Центру української культури та освіти «Осередок» (The Ukrainian Cultural and Educational Centre «Oseredok»).

Актуальність даного дослідження пов'язана з сучасним національно-культурним рухом, що втілюється в розгортанні діяльності широкого кола організацій, спілок, мистецьких, освітніх та наукових центрів, запровадженні нових українських фестивалів та освітньо-культурних проектів, відкритті та дослідженні, раніше засекречених, архівних документів як на етнічній території, так і в осередках української діаспори Канади.

Окремі аспекти даної проблеми були розкриті в працях таких дослідників, як: Джус О. В. [2], Матяш І. Б. [4; 5; 6], Солонська Н. Г. [10; 11] і Приймак Т. М. [12]. Проте, на наш погляд, пам'яткоохоронна та соціокультурна діяльність Центру української культури та освіти «Осередок» варта більш глибокого наукового 
дослідження. Наразі досить важливою справою є дослідження культурних артефактів, архівних матеріалів, розгляд наукових, освітніх, фольклорних та мистецьких проектів «Осередку», а також аналіз діяльності громадсько-політичних діячів, членів Українського національного об'єднання, митців та науковців, які виступили у ролі засновників центру, сприяли його розвитку та зробили вагомі внески у поповнення його коштовних колекцій.

Станом на початок Другої світової війни тривала друга хвиля української імміграції до Канади. Проте через воєнні обмеження та бюрократичні перепони у 1941 p. процеси переселення практично припинились. Перебуваючи у складі Британської співдружності, Канадський домініон вступив у війну 10 вересня 1939 р. Держава в цей час переживала далеко не кращу підготовку, що було пов'язано передовсім зі станом економіки, сильно виснаженої від наслідків Великої депресії, слабкої, малочисельної, погано оснащеної армії, антимобілізаційних настроїв населення, особливо у провінції Квебек. Політична криза назрівала також і через невдалі виступи у війні, багаточисленні втрати армії, яка налічувала 1,1 млн. канадців, з них близько 30 тис. українців. Ситуація покращилась тільки в 1944 р. в ході Нормандської операції, коли канадські війська гідно виступили у бою за звільнення Нідерландів. До того ж військові замовлення сприяли інтенсивній індустріалізації та зростанню економіки держави. Вагомий внесок у даний процес зробила і українська діаспора, представники якої не тільки займали різні щаблі армії від рядових до офіцерів, але і працювали на військових підприємствах, у науководослідних центрах, де розробляли нові види оборонного та наступального озброєння. У цей тяжкий для українців час, як ніколи раніше, постала потреба у міцній консолідації, збереженні та примноженні культурної ідентичності. Ті пам’ятки, що були поза межами України - в Берліні (Архів Української установи «Довір'я»), Парижі (Книгозбірня ім. С. Петлюри), Празі (Український Музей) і Варшаві, німці повивозили. Більшість із них зникла безслідно. В Україні такі інституції розграбовували або нищили. По розгромі збірників українських пам'яток в Свропі не лишилось жодного центру, куди б люди могли надсилати твори постійної вартості на збереження [13, с. 3-4]. Отже, відчувалась нагальна потреба у відкритті нової установи, яка б виконувала пам'яткозберігаючу та дослідницьку роль. В 1943 р. за сприяння УНО, а також відомого історика і політичного діяча П. М. Юзика, композитора, диригента й етнографа О. А. Кошиця, його дружини, відомої співачки Т. О. Кошиць, музикознавця і композитора П. П. Маценка, публіциста і дипломата M. I. Мандрики, поета, члена УВАН і НТШ Т. К. Павличенка та багатьох інших видатних українців в м. Вінніпег було сформовано Громадський комітет для вирішення організаційних питань. 25 березня 1944 р. членами комітету було видано офіційний указ про створення Центру української культури та освіти «Осередок», який об’єднав у собі архів, бібліотеку, музей, мистецьку галерею, видавництво і навчальний заклад. Першим головою «Осередку» став український військовий, громадський діяч, вчений-агроном, член УНО та один із засновників Конгресу українців Канади - Володимир Коссар. Мета нової української інституції полягала в консолідації активних сил задля розвитку української культури й освіти в Канаді, належній репрезентації українських культурних надбань у культурі Канади, досягненні конструктивної співпраці українців з представниками інших етнічних груп Канади й Америки [4, с. 66]. 28 січня 1945 р. в Українському Національному Домі у Вінніпезі відбулися перші збори членів «Осередку», на яких було ухвалено статут та сформульовано основні завдання Центру: 
1) пошук, акумулювання, зберігання, експозиціонування, а також за можливості реставрація витворів мистецтва, виробів народно-ужиткового мистецтва, етнічного одягу, церковного начиння, документів, особистих щоденників, листів, фольклорних і літературних творів, наукових праць, військових і спортивних трофеїв та нагород;

2) адміністрування та організація роботи культурологічного, наукового, освітнього та технічного персоналу закладу;

3) пошук меценатів, залучення інвестицій, збирання пожертв, а також заохочення митців та колекціонерів за спільну соціокультурну діяльність, яка сприятиме різнобічному розвитку «Осередку»;

4) запровадження видавничої діяльності, яка включатиме друк підручників та книжок, спрямованих на культурну просвіту, професійну підготовку молоді i старшого покоління українців Канади;

5) розробка освітніх програм, влаштування суспільних обговорень, конференцій, симпозіумів та введення українознавчих курсів;

6) знайомство канадців інших етнічних груп з українською культурою. Підготовка театральних вистав, хореографічних номерів, концертів, фестивалів, історичних та фольклорних реконструкцій, продукція кіно, видавання української літератури іноземними мовами;

7) матеріальна або інформаційна допомога аналогічним організаціям.

Важливе історичне значення має будівля, в якій знаходиться Центр української культури та освіти «Осередок». На початку своєї роботи під потреби Центру було виділено частину будинку Українського Національного Об'єднання. Проте у зв'язку зі зростанням колекцій та суттєвим розширенням напрямків роботи у другій половині XX ст. площа та якість приміщень вже не задовольняла потреби «Осередку». На початку 1970-х рр. дирекцією Центру було прийнято рішення орендувати для власної бібліотеки 4-й поверх славнозвісної пам'ятки архітектури - будівлі Біблійного товариства, яке було створено в Англії у 1804 р. та мало на меті донесення Слова Божого до «язичників» усього світу. В 1808 р. товариство розпочало свою місію в Канаді, організувавши видання та переклад Біблії на численні мови, копії якої розповсюджувало безкоштовно. Місіонери вважали, що подібні заходи допоможуть іммігрантам налагодити життя на новій землі. Завдяки спільним зусиллям уряду провінції Манітоба, Біблійного товариства та пожертвам простих мирян у 1913 р. було збудовано п’ятиповерхову будівлю, яка охоплювала приміщення для служіння проповіді, недільну школу, їдальню та бібліотеку. На початку Першої світової війни, потік іммігрантів з Європи суттєво зменшився, тому товариство більше не відчувало потребу у такій затишній будівлі. Було прийнято рішення спочатку здати будинок в оренду благодійним організаціям, а потім у 1949 р. взагалі його продати Українській національній видавничій компанії, яка друкувала українознавчу газету «Новий шлях» («New Pathway»). 31950 по 1958 pр. у будівлі також працювали такі спілки, як: Українська національна федерація молоді, Українська асоціація ветеранів війни та Українська жіноча організація. Нарешті, у 1977 р. редакція «Нового шляху» переїхала в інше місце і будинок повністю перейшов у власність «Осередку». Завдяки зусиллям федерального та провінційного урядів, філії УНО, Вінніпезької фундації та української громади було зібрано $\$ 500$ тис., які було витрачено на реконструкцію внутрішнього оздоблення під потреби організації.

В 1944 р. «Осередок» розпочав працю без жодних засобів. Протягом 10 років він провадив постійні зв'язки 3 людьми в Канаді й інших країнах [13, с. 10]. Нині «Осередок» понад усякі надії має великі колекції книжок, документів, рукописів, 
художніх творів, часописів, картин, різьби, вишивок та цінні колекції архівних документів i речей. 3 усіх країв світу постійно надходять нові матеріяли i поповнюють давніше зібрані [9, с. 25-26]. Структурно Центр української культури та освіти «Осередок» містить архів, бібліотеку, музей, галерею, лекторій та видавництво.

Архів «Осередку» має найбільшу в Канаді колекцію українознавчих документів, яка становить понад 2 тис. футів артефактів, пов'язаних 3 різними періодами української історії (XVI-XX ст.), діяльністю державних установ (УНР, ЗУНР), організацій (УНО, ОУН, Комітету Українців Канади, Світової федерації українських політичних в'язнів, Товариства опіки над українськими переселенцями св. Рафаїла та ін.), літературні, публіцистичні, наукові рукописи, листи, партитури та клавіри талановитих співвітчизників (В. К. Авраменка («Українські національні танки, музика і стрій» (1947)), І. М. Боберського («Щоденник» (2003)), Д. К. Гуменної (спогади про Київ, машинописи літературних творів), С. М. Коновальця (документи та часописи «Сурма» (1927-1932) і «Літопис Червоної калини» (1935-1939)), подружжя Кошиців (нотні збірки, «Спогади» (1947-1948) у двох томах), П. П. Маценка (збірки хорових творів), М. І. Мандрики (збірки поезій та наукові праці «Теорія господарської дипломатії» (1934) та ін.), Є. Д. Онацького (мемуари «Сторінки з Римського щоденника» (1920-1943)), С. В. Храпливого («Господарство Холмщини і Підляшшя» (1944)), М. Г. Марунчака («Студії до історії українців Канади» у 5 томах (1964-1980) та ін. роботи), М. Д. Селешка (листи, політичні статі «Націократія», «Три воєнні роки ОУН») та ін. Серед колекцій можна побачити дуже цінний Ірмолой Георгія Тяпецького 1733 р. Крім того, фонди архіву складаються 3 понад 75 тис. фотографій та аудіовізуальних матеріалів, які відтворюють доволі цінну інформацію 3 історії Української революції (1917-1921), внутрішньої та зовнішньої політики УНР, історії еміграції, духовного, наукового, культурного, громадського, економічного, побутового життя української діаспори Канади. Зміну політичного та територіального устрою України 31550 по 1990 рр. чудово ілюструє колекція з понад 350 аркушів географічних карт та близько сотні географічних праць дослідників XVI-XIX ст. У 2005-2006 рр. Архів ОУКО разом 3 Архівами і спеціальними колекціями Манітобського університету та Архівом Саскачеванського університету приєднались до веб-проекту «The Prairie Immigration Experience, 1900-1950» (Досвід імміграції у канадські прерії, 1900-1950) [1, с. 517-518].

«Осередок» має досить багаті бібліотечні фонди, які нараховуют понад 40 тис. томів, близько 10 тис. періодичних видань та понад 400 назв політичних, наукових, духовних, літературних та мистецьких часописів, що публікуються на території Австралії, Канади, США, країн Латинської Америки та Європи. Понад 75 років книгозбірня «Осередку» поповнювалась рідкісними приватними виданнями, досить часто у вигляді подарунків від видатних представників української діаспори Канади: родини Кошиців, П. І. Зварича, Ю. Лісового, П. П. Маценка, В. Климківа, напрочуд цінною є особиста бібліотека Є. М. Коновальця, яку люб'язно передала його дружина О. Федак-Коновалець. Окремі фонди складають книгозбірні українських організацій таких, як: Конгрес українців Канади, Крайова екзекутива УНО, Союз українських канадійських ветеранів тощо. В 1953 р. засновано Відділ рідкісних праць i документів. Сюди входять виключно праці унікального порядку, або ті, яких на ринку неможливо набути [13, с. 10]. Серед рідкісних книг можна виділити Номоканон, який було видано у друкарні Києво-Печерського монастиря у 1624 р. На початку XX ст. унікальну пам'ятку привіз з України до Канади український священник о. Йосафат Жан. Пізніше книгу було подаровано бібліотеці монастиря в оселі Шептицьке, що у 
Квебеку. Внаслідок пожежі у 1938 р. монастир було знищено, але Номоканон було врятовано і до передачі «Осередкові» в 1976 р., він перебував в м. Валь-д'Ор у приватній колекції родини Андрущишиних.

Музей «Осередку» має дуже різноманітну колекцію артефактів в обсязі 8 тис. предметів. Хоча центр було засновано ще в 1944 р., музейний відділ відкрив свої двері відвідувачам тільки в 1951 р., що було пов'язано передусім з проведенням кропіткої роботи з реставрації та класифікації великої кількості цінних експонатів, які українці надсилали як з етнічної території та різних провінцій Канади, так i, загалом, зі всіх куточків нашої планети. Музею «Осередку» належать класичні зразки декоративно-ужиткового мистецтва: писанки, рушники, килими, керамічний посуд, народний одяг з регіональними орнаментами, глибокими символами, ляльки, макети обрядового хліба, хат, керамічні, різьбярські, дерев'яні, ювелірні вироби, побутові та музичні інструменти; церковне начиння: ікони, хрести, посуд, текстильні вироби; військові трофеї, відзнаки, мундири, а також меблі з персональними речами, які належали О. А. Кошицю, С. М. Коновальцю, Р. Р. Гонсету та ін. Експонати музею не тільки допомагають зберегти національну ідентичність, перебуваючи далеко від України, але і знайомлять всіх канадіян, незалежно від расових, мовних відмінностей, релігійних переконань, з багатим духовним та світським світоглядом пересічних українців. В українських артефактах можна простежити еволюційний шлях від старовинних тисячолітніх зразків до витворів сучасних майстрів, які продовжують давні традиції українського народу в Канаді.

Діяльність «Осередку» охоплює також сферу образотворчого мистецтва. В колекціях мистецької галереї можна побачити полотна понад 30 українських художників, які належать до плеяди визначних творців від реалізму XIX ст. до авангардизму XX ст. Загальна кількість робіт сягає понад 750 картин, малюнків, гравюр та ікон, які «Осередок» отримував в дар від самих художників, або викуповував у колекціонерів усього світу. Галерея Центру може похвалитися роботами таких художників, як: К. О. Трутовський (художник-реаліст), О. П. Архипенко (живописець, скульптор-кубіст), О. В. Грищенко (графік, експресіоніст, письменник), М. I. Мороз (автор 3 тис. портретів та пейзажів, пізніше працював в стилі абстрактного експресіонізму), М. М. Левицький (маляр, графік та прозаїк), Я. Я. Гніздовський (графік, кераміст, іконописець), К. Шонк-Русич (художникемаліст, мистецтвознавець, видавець), Я.Сурмач-Міллс (ілюстраторка та вітражистка), а також визначними канадськими митцями українського походження: Я. Майданик (художник, письменник і педагог), І. М. Кейван (графік, живописець, мистецтвознавець, член НТШ), П. М. Куч (художник-карикатурист), В. Д. Курилик (художник і письменник), Д. Стриєк (художник-примітивіст) та багатьох ін. В 1970-х pp. мистецька галерея «Осередку» мала статус найбільшої збірки авангардних робіт у провінції Манітоба. Серед визначних виставок Центру можна згадати ювілейну експозицію робіт українського художника М. М. Левицького, з нагоди 50-річчя його творчої діяльності, яка пройшла в 1985 р. Саме Мирон Левицький підвищив рівень графічного оформлення української книжки в Канаді, завдяки використанню кращих традицій українського народного мистецтва.

При Центрі української культури та освіти «Осередок» діють Вищі освітні курси, які було започатковано ще в 1940 р., завдяки широкій патріотичній та благодійній роботі УНО, а також залученні педагогів та священників, які не тільки сповідували різні релігійні та політичні погляди, але і працювали на громадських засадах, бо головною об'єднуючою засадою української діаспори Канади $\epsilon$ 
збереження національної ідентичності. Ці курси розпочались з 3-ма учителями і 18 студентами в 1940-м р., а вже в 1944 р. мали 16 учителів і інструкторів та 81 курсанта [7, с. 6]. 5-місячні курси відбуваються зазвичай взимку та мають три відділи: англійської, української мови та господарчі курси (крою, шиття, вишивки, кулінарії тощо). Крім того, завдяки освітній програмі «Осередку» та благодійній організації «Одноцентовий Фонд» для талановитої української молоді, яка вчиться в цілій низці канадських вишів і вивчає журналістику, славістику або міжнародне право було започатковано стипендію у розмірі \$500. За час свого існування на Вищих освітніх курсах було виховано цілу плеяду майбутніх вчителів, науковців, інженерів, митців, громадських діячів і, загалом, свідомих представників української діаспори Канади.

Важливою сферою діяльності «Осередку» $є$ робота видавництва, яке друкує наукові та художні твори українською та іноземними мовами під серією «Культура й Освіта». Діяльність видавничого центру направлена як на підтримку молодого покоління наших співвітчизників, так і на знайомлення світового співтовариства 3 героїчною історією, духовним світом, багатою культурою та науковим доробком українського народу. Так, завдяки плідній роботі «Осередку» було видано такі роботи, як: «3 піснею через світ. Подорож Української Республіканської Капелі» (1952) Олександра Кошиця, «Давня українська музика і сучасність» (1952) Павла Маценка, «Перші кроки на еміграції» (1955) Ірени Книш та ін.

Отже, українознавча, експозиційна та дослідницька діяльність Центру української культури та освіти «Осередок» має вельми важливе значення для збереження національної ідентичності у Канаді. Саме «Осередок» виступив тією об'єднуючою силою, яка зібрала під одним культурним покровом українців з різними релігійними переконаннями, політичними поглядами і життєвими цінностями у часи воєнного лихоліття, політичної кризи, строкатого економічного стану, квебекського сепаратизму, Холодної війни. Засновниками та меценатами «Осередку» виступили визначні українські діячі - члени УНО, КУК, НТШ, зокрема митці: О. Кошиць, Т. Кошиць, П. Маценко, М. Мандрика, Т. Павличенко; політики: П. Юзик, В. Коссар; науковці: М. Марунчак, Я. Рудницький, Т. Приймак та ін. За останні 76 років своєї роботи «Осередок» став беззаперечним гарантом колективної пам'яті та зберігачем традицій українського народу. Навіть будинок організації, у минулому Дім Біблійного товариства, має велику духовну силу, яка сприяє благородній соціокультурній місії. Надзвичайно вражає багатогранність діяльності «Осередку», яка охоплює архівну, бібліотечну, музейну, освітню та видавничу роботу. Архів організації має найбільшу в Канаді колекцію документів, мемуарів, світлин, карт, яка охоплює період XVI-XX ст. Цінними є документи та спогади I. М. Боберського, Є. М. Коновальця, подружжя Кошиців, а також пам'ятка XVIII ст. - Iрмолой Георгія Тяпецького. «Осередок» має дуже багаті бібліотечні фонди, які становлять понад 40 тис. томів і 10 тис. періодичних видань. Серед рідкісних книг можна виділити Номоканон XVII ст. Обсяг колекції музею центру складає 8 тис. експонатів, що охоплює предмети декоративно-ужиткового мистецтва, музичні інструменти, церковне начиння, персональні речі. В колекціях мистецької галереї можна побачити полотна понад 30 українських художників від реалізму до авангардизму. При «Осередку» діють Вищі освітні курси, які виховали чимало видатних українців свідомих громадян Канади. Видавнича діяльність центру сприяла не тільки розвитку науки та мистецтва, але і познайомила весь світ з багатою українською культурою. Отже, Центр української культури та освіти «Осередок»є взірцем націооб'єднуючої організації, яка гідно тримає жовто-блакитний прапор на теренах світової арени! 


\section{Джерела та література:}

1. Архівна україніка в Канаді : довідник / упоряд.: І. Б. Матяш, Р. В. Романовський, М. В. Ковтун. - К. : Держкомархів України, 2010. - 882 с.

2. Джус О. В. Теорія і практика професійної підготовки молоді у закладах освіти української діаспори (XX ст.) : дис. ... доктора пед. наук : 13.00.01 / Джус Оксана Володимирівна; Східноукраїнський національний університет ім. В. Даля. - Київ, 2020. -475 с.

3. Марунчак М. Г. Студії історії українців Канади. Розвідки та документи до міжвоєнноі доби / М. Г. Марунчак. - Вінніпег : Trident Press, 1980. - Т. 5. - 215 с.

4. Матяш I. Б. Архівна та рукописна україніка в Канаді / I. Б. Матяш // Український археографічний щорічник / ред. П. С. Сохань. - К. : Бізнесполіграф, 2007. - Вип. 12. - С. 37-82.

5. Матяш І. Б. Осередок української культури і освіти // Енциклопедія історії України : у 10 т. / редкол.: В. А. Смолій (голова) та ін. - К. : Наукова думка, 2010. - Т. 7 : Мл-О. - С. 649.

6. Матяш I. Б. Український дипломатичний архів як джерело дослідження історії консульської служби / І. Б. Матяш // Рукописна та книжкова спадщина України / ред. Л. А. Дубровіна. - К. : Нац. б-ка України ім. В. І. Вернадського, 2016. - Вип. 20. - С. 252-266. 7. Осередок культури й освіти. Цілі і завдання / упоряд. В. Коссар, Т. К. Павличенко. Вінніпег : The Ukrainian National Publishing, 1945. - 23 c.

8. Осередок української культури й освіти в Вінніпегу // Українська мала енциклопедія : 16 кн. : у 8 т. / ред. Є. Д. Онацький. - Буенос-Айрес : Дзвін, 1962. - Т. 5, кн. Х : Літ. Ол-Пер. - C. 1250 .

9. Павличенко Т. К. Рух Національної Єдності. 3 приводу Ювілейної Конференції УНО Канади / Т. К. Павличенко. - Вінніпег : Новий шлях, 1952. - 31 с.

10. Солонська Н. Г. Книжкова комунікація українських іммігрантів у Канаді як засіб національного спілкування / Н. Г. Солонська // Українознавчий альманах / ред. С. В. Руденко. - К. : Міленіум, 2016. - Вип. 19. - С. 152-155.

11. Солонська Н. Г. Українська канадіана : анотований покажчик видань 3 фонду Національної бібліотеки України ім. В. І. Вернадського / Н. Г. Солонська, Г. О. Борисович, наук. ред. Г. І. Ковальчук. - К. : Нац. б-ка України ім. В. І. Вернадського, 2017. - 176 с.

12. Prymak T. M. A visit to Oseredok: The Ukrainian museum and library in Winnipeg / T. M. Prymak. - Toronto : University of Toronto, 2018. - $16 \mathrm{p}$.

13. Ukrainian Cultural and Educational Centre 1944-1954 / Ed. T. O. Koshytz, P. P. Macenko. Winnipeg : The Ukrainian National Publishing, 1954. - 14 p.

\section{References:}

1. Matyash, I. B., Romanovs'kyy, R. V., and Kovtun, M. V. comps., 2010. Arkhivna ukrayinika v Kanadi: dovidnyk. Kyiv: Derzhkomarkhiv Ukrayiny. [in Ukrainian].

2. Dzhus, O. V., 2020. Teoriya i praktyka profesiynoyi pidhotovky molodi u zakladakh osvity ukrayins'koyi diaspory (XX st.) [Theory and practice of vocational training of youth in educational institutions of the Ukrainian diaspora $\left(20^{\text {th }}\right.$ century)]. D.Ed. Volodymyr Dahl East Ukrainian National University. [in Ukrainian].

3. Marunchak, M. H., 1980. Studiyi istoriyi ukrayintsiv Kanady. Rozvidky ta dokumenty do mizhvoyennoi doby, Vol. 5. Winnipeg: Trident Press. [in Canadian].

4. Matyash, I. B., 2007. Arkhivna ta rukopysna ukrayinika v Kanadi [Archival and manuscript Ukrainian in Canada]. In: Sokhan, P. S. ed., 2007. Ukrayins'kyy arkheohrafichnyy shchorichnykUkrainian Archaeographic Yearbook, 12, pp. 37-82. [in Ukrainian].

5. Matyash, I. B., 2010. Oseredok ukrayins'koyi kul'tury i osvity [Ukrainian Cultural and Educational Centre]. In: Smoliy, V. S. ed., 2010. Entsyklopediya istoriyi Ukrayiny: u 10 t. Encyclopedia of the History of Ukraine in 10 vols, Vol. 7. M1.-O. Kyiv: Naukova dumka. p. 649. [in Ukrainian].

6. Matyash, I. B., 2016. Ukrayins'kyy dyplomatychnyy arkhiv yak dzherelo doslidzhennya istoriyi konsul's'koyi sluzhby [Ukrainian diplomatic archive as a source of research on the history of the consular service]. In: Dubrovina, L. A. ed., 2016. Rukopysna ta knyzhkova spadshchyna Ukrayiny- 
Manuscript and book heritage of Ukraine, 20, pp. 252-266. [in Ukrainian].

7. Kossar, V., and Pavlychenko, T. K. comps., 1945. Oseredok kul'tury y osvity. Tsili i zavdannya. Winnipeg: The Ukrainian National Publishing. [in Canadian].

8. Onats'kyy, Ye. D. ed., 1962. Oseredok ukrayins'koyi kul'tury i osvity v Winnipegu [Ukrainian Culture and Education Center in Winnipeg] Ukrayins'ka mala entsyklopediya: $16 \mathrm{kn} .:$ u 8 t. Ukrainian small encyclopedia: 16 books.: in 8 vol., Vol. 5, book 10, Ol-Per. Buenos-Aires: Dzvin. p. 1250. [in Argentine].

9. Pavlychenko, T. K., 1952. Rukh Natsional'noyi Yednosti. Z pryvodu Yuvileynoyi Konferentsiyi UNO Kanady. Winnipeg: Novyy shlyakh. [in Canadian].

10. Solons'ka, N. H., 2016. Knyzhkova komunikatsiya ukrayins'kykh immihrantiv u Kanadi yak zasib natsional'noho spilkuvannya [Book communication of Ukrainian immigrants in Canada as a means of national communication] In: Rudenko, S. V. ed. Ukrayinoznavchyy al'manakh Ukrainian Studies Almanac, 19, pp. 152-155. [in Ukrainian].

11. Solons'ka, N. H., Borysovych, H. O., and Koval'chuk, H. I., 2017. Ukrayins'ka kanadiana: anotovanyy pokazhchyk vydan' z fondu Natsional'noyi biblioteky Ukrayiny im. V. I. Vernads'koho. Kyiv: Nats. b-ka Ukrayiny im. V. I. Vernads'koho. [in Ukrainian].

12. Prymak, T. M., 2018. A visit to Oseredok: The Ukrainian museum and library in Winnipeg. Toronto: University of Toronto. [in Canadian].

13. Koshytz, T. O. ed., 1954. Ukrainian Cultural and Educational Centre 1944-1954. Winnipeg: The Ukrainian National Publishing. [in Canadian].

Отримано: 07.11.2020 p. 


\title{
MYKOLA BYTYNSKYI AND HIS PROJECTS OF “COSSACKIA”'S SYMBOLS
}

\author{
Andrii Grechylo \\ ORCID: https://orcid.org/0000-0003-2947-2872 \\ DSc (History) \\ M.S.Hrushevsky Institute of Ukrainian Archeography \\ and Source Studies, NAS of Ukraine \\ 24, Vynnychenka Str., Lviv, 79008, Ukraine \\ grechylo@yahoo.com
}

The article examines the beginning of Mykola Bytynsky's practical activity in the field of heraldry and vexillology during his stay in Prague in the 1920s and 1930s. This work was connected with the creation of symbols for the Cossackia political project, which arose among emigrants from the Don, Kuban, Terek and other Cossack regions of the former Russian Empire.

Mykola Bytynsky together with Ignat Bilyi worked out projects of the state emblem and flag of "Cossackia". The flag was designed based on the most popular colors of separate lands, so it was a tricolor with blue, crimson and yellow stripes. The large state emblem of "Cossackia" included the next symbols: in the main shield were placed traditional Cossack attributes (mace and two bunchuks), and around were 7 shields with emblems of the main Cossack regions: Don, Kuban, Terek, Yaik, Astrakhan, Orenburg and Kalmykia. Bytynsky also worked on projects for the coats of arms of the Free Cossacks of Siberia, Semirechye, Transbaikalia, the Ussuri, and other lands up to the Pacific Ocean. But they did not receive support and did not enter the large coat of arms. A monochrome postcard with the coat of arms of the "Cossackia" was published in Prague. In addition to graphic versions, Bytynsky also made a color album of symbols of the Cossack lands.

The question of creating the anthem of the future state was also raised. Bytynsky actively worked on the design of the magazine "Free Cossacks" and other publications, designed covers, drew screensavers, maps, developed designs of badges and emblems. The gained experience became a precondition for Bytynsky's further work on the projects of state symbols of Ukraine.

Key words: Mykola Bytynsky, "Cossackia”, Free Cossacks, coat-of-arms, flag, Ignat Bilyi.

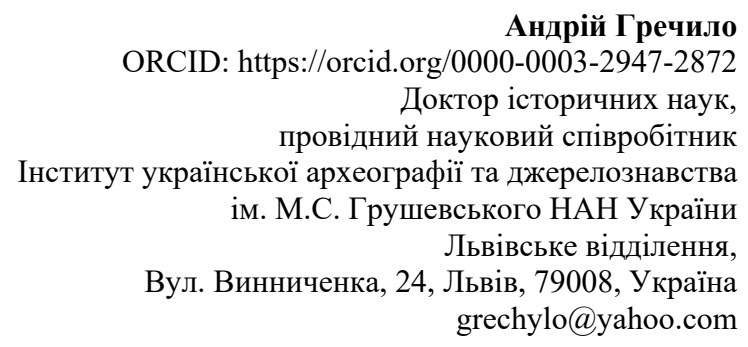

\section{МИКОЛА БИТИНСЬКИЙ ТА ЙОГО РОБОТА НАД СИМВОЛАМИ «КОЗАКІЇ»}

У статті розглядається питання про початок практичної діяльності Миколи Битинського у галузі геральдики та вексилологї під час його проживання у Празі в 1920- 
1930-х рр. Ця прачя була пов'язана зі створенням символів для політичного проєкту «Козакія», який виник у середовищі емігрантів з Дону, Кубані, Терека та інших козацьких областей колишньої Російської імперії.

Микола Битинський разом із Гнатом Білим опраџювали проєкти державного герба та прапора Козакії. Прапор було розроблено на основі найбільш популярних кольорів окремих козацьких регіонів, тому ие був триколор з синьою, малиновою і жовтою смугами. Для великого державного герба Козакії в головному щиті були вміщені традиційні козацькі атрибути (булава і два бунчуки), а навколо щуе 7 щчитів із символами основних козацьких земель: Дон, Кубань, Терек, Яїк, Астрахань, Оренбург і Калмикія. Битинський також опрачював проєкти для гербів вільного козачтва Сибіру, Семиріччя, Забайкалля, Уссурійського краю та інших земель аж до Тихого океану. Але вони не отримали підтримки i до великого герба не увійшли. У Празі була видана монохромна листівка із гербом Козакії. Окрім графічних варіантів Битинський виконав кольоровий альбом символів козацьких земель.

Також порушувалося питання про створення гімну майбутньої держави. Битинський активно працював над оформленням часопису «Вільне козачтво» та інших видань, оформляв обкладинки, малював заставки, карти, розробляв проєкти значків $і$ емблем. Отриманий досвід став передумовою для подальшої пращчі Битинського над проєктами державних символів Украӥни.

Ключові слова: Микола Битинський, Козакія, вільне козачтво, герб, прапор, Гнат Білий.

Одна 3 перших геральдичних робіт відомого українського геральдиста i фалериста Миколи Битинського стосувалася розробки символів для «Козакії» політичного проєкту, який виник у середовищі емігрантів у міжвоєнний період ХХ ст.

Микола Битинський народився 24 листопада (6 грудня - за новим стилем) 1893 р. у місті Літині на Поділлі. Дитячі та юнацькі роки провів у Кам'янціПодільському, де отримав початкову освіту, потім закінчив дворічні педагогічні курси та 4-класну Художньо-промислову школу у галузі малювання, навчаючись у художників В. Розвадовського та К. Роота. Під час Першої світової війни, як зазначав сам Битинський у своїй автобіографії, він «по закінченні Військової старшинської школи в Оранієнбаумі брав участь у боротьбі на австрійському та германському фронтах у Російській армії в ранзі поручника». До Армії УНР був мобілізований 1919 р. Після переходу Армії УНР через Збруч восени 1920 р. інтернований у складі 6-ї Січової дивізії у Польщі й перебував у таборах в Александрові-Куявському, а потім у Щипйорно біля Каліша, де його підвищено у званні до сотника. У таборах Битинський працював на посаді начальника Культурно-освітнього відділу Штабу 6-ї дивізії, брав участь у редколегіях кількох часописів, викладав історію України на курсах українознавства. Після ліквідації таборів влітку 1923 р. він переїжджає до Чехословаччини де вступає до Українського високого педагогічного інституту імені M. Драгоманова в Празі. Там же «приватно студіював графіку й загальне знаківництво, зокрема геральдику 3 ділянки державних, земських та інших корпораційних гербів i знаків». При цьому особливу увагу приділяв «різним символам й емблемам 3 українського історичного знаківництва». Тоді ж Битинський починає активно займатися приватною мистецькою працею - малярством і графікою.

У цей самий час у Празі сформувався досить сильний осередок Вільнокозацького руху, який об'єднував вихідців з Кубанського, Донського, Терського війська та інших козацьких організацій. Радикалізація цього руху призвела до ідей створення окремого державного утворення під назвою «Козакія». Такі проєкти не влаштовували «білу» російську еміграцію, яка намагалася схиляти подібні рухи на свою сторону. Уряд 
Української Народної Республіки на еміграції також відстежував становлення Вільнокозацького руху, передовсім з огляду на «кубанське питання» та збереження проукраїнської орієнтації серед кубанських козаків. Тому в 1927-1928 рр. ним було створено спеціальну комісію для впливу на Вільнокозацький рух у складі Максима Славинського, Володимира Сальського, Василя Філоновича та Тимоша Олесіюка, а згодом до неї увійшов і Микола Битинський ${ }^{1}$. Всі вони активно публікували різні матеріали у часописі «Вольное Казачество - Вільне Козацтво», що почав виходити як літературний і політичний двотижневик з 1927 р. у Празі під редакцією полковника Михайла Фролова та Гната Білого. Участь Битинського не обмежувалася лише художнім оформленням видання, виготовленням обкладинок і заставок (іл. 1-2), але він також публікував тут українською мовою різні публіцистичні дописи [2, с. 18-19] та свої вірші під псевдонімом Микола Оверкович [10, с. 1]. У 1929 р. він виконав проєкт прапора для кубанців, які входили до Вільного козацтва.

Один із видавців часопису, колишній командир Донського кінного полку 3-ї Залізної Дивізії Армії УНР полковник Михайло Фролов внаслідок загострення туберкульозу відійшов від справ і помер 11 липня 1930 р. Микола Битинський розробив проєкт надгробного пам’ятника з гербами України та Війська Донського, який було встановлено на могилі полковника Фролова у Літомишлі.

Розвиток ідеології формування державності Козакії потребував передовсім визначення іiі територіальних меж, чим активно займався у своїх публікаціях у часописі Гнат Білий [1, с. 1-25]. Микола Битинський отримав можливість поекспериментувати у справі символів нової держави, землі якої мали простягатися від Чорного моря до Оренбурзьких степів. На розробленій разом із Білим 1929 р. карті Козакії, яка публікувалася на тильній обкладинці часопису, було подано 7 гербів, які мали уособлювати землі окремих козацьких військ: Донського, Кубанського, Терського, Калмицького, Астраханського, Яїцького та Оренбурзького (іл. 3). Ці ж 7 гербів Битинський помістив і на виконаній ним обкладинці календаря-альманаха на 1930 рік (іл. 4). У цьому ж календарі він опублікував доволі велику розвідку про козацькі герби [3, с. 99-129]. Цікаво, що ця та наступні публікації у часописі на тему символів написані російською мовою, однак підписані в транслітеруванні 3 української - «Мыкола Бытынськый». Окрім загального огляду питання про принципи формування державних гербів автор також детально зупинився на можливостях використання символів для окремих частин майбутньої держави. При цьому він окрім знаків семи вже згаданих земель козацьких військ розглянув ще можливі символи Сибірського, Єнісейського, Семиріченського, Забайкальського, Амурського та Уссурійського вільного козацтва, дійшовши таким чином до узбережжя Тихого океану. Якщо у випадках з Донським та Кубанським військом, які мали доволі давні емблематичні традиції, Битинський аналізував різні територіальні та військові символи і на їхній основі формував свої пропозиції, то для Калмицького козацтва він розробив новий знак на основі зображення кречета як «символа Духахранителя Чингізхана», а для інших відредагував та доповним козацькими символами герби російських адміністративних територій - губерній та областей, при цьому вилучивши із них зображення двоголових орлів.

Наступна стаття, опублікована вже у часописі «Вільне козацтво» 1930 р., стосувалася питання прапорів [4, № 54, с. 12-14; № 55, с. 10-12]. Розглянувши загальні принципи створення таких символів та вже усталені прапори Донського

\footnotetext{
${ }^{1}$ Висловлюю подяку п. Тамарі Скрипці (Музей-архів ім. Д. Антоновича УВАН у США, Нью-Йорк) за уточнення цієї інформації.
} 
(синьо-жовто-червоний) та Кубанського козацтва (синьо-малиново-зелений), Микола Битинський висловив свої пропозиції щодо інших регіонів. За основу для таких прапорів він переважно обирав також полотнища, складені 3 горизонтальних чи вертикальних кольорових смуг, забарвлення яких черпав із територіальних гербів.

Як підсумок опублікованих раніше матеріалів було подано у новій публікації проєкти герба та прапора Козакії [13, с. 15-19]. Ця стаття вийшла без вказаного автора, хоча в примітці зазначено, що ідея запропонованого проєкту державного герба Козакії належить Гнату Білому, а геральдичне впорядкування, графічне виконання та блазонування виконав Микола Битинський. Для прапора вирішено вибрати кольори, які найчастіше зустрічаються на козацьких прапорах. Правда, цей підрахунок відбувався на підставі не лише реальних символів, але й пропонованих раніше у статті Битинського варіантів. У підсумку найчастіше вживаними виявилися: жовтий колір - 9 разів, червоний -8 , синій і білий - по 6. 3 цього вирішено залишити жовтий, замість червоного використати малиновий як такий, що має «цінність історичну, як один із кольорів давнішого козацтва запорозького», а 3-поміж синього та білого обрати синій. На цій підставі скомбіновано триколор із рівношироких горизонтальних смуг: верхньої синьої, середньої малинової та нижньої жовтої.

Для державного герба запропоновано для основного знаку використати булаву та бунчуки, а колористику взяти з проєктованого прапора. Навколо нього мали бути сім краєвих гербів (іл. 5).

I. Головний герб: у синьому полі скошені навхрест два золоті бунчуки давніх козацтв - запорозького та донського, 3 малиновими прикрасами i срібними ланцюгами, перев'язані із поставленою у стовп золотою булавою зі срібними та малиновими прикрасами. Булава у щиті означала свободу, рівність і народовладдя. Щит увінчували 7 золотих булав, які символізували рівність усіх козацьких військ у державному союзі. Щит довкола оздоблювали золоті декоративні гілки.

Обабіч та внизу головного герба на гілках лавра і дуба, перев’язаних синьомалиново-жовтою стрічкою, розташовано 7 щитів із краєвими гербами, увінчаних обласними мурованими коронами. Ці герби подані «за давністю їхнього виникнення».

II. Донський герб: у синьому полі стрибає золотий степовий олень із червоними очима, копитами і рогами, пронизаний зі спини такою ж стрілою.

III. Кубанський герб: щит двічі розтятий із синім правим та зеленим лівим боковиками, у середньому малиновому полі золота сторожова вишка над двома срібними шаблями (запорозькою та кавказькою), скошеними обабіч золотими ефесами додолу, під ними - золотий півмісяць ріжками вгору, поверх вишки срібний щит, на якому запорожець у малиновій одежі, який тримає у лівиці таку ж корогву зі срібним прямим хрестом, а в правиці-золотий мушкет.

IV. Терський герб: у чорному щиті срібний правий хвилястий перев'яз поверх скошеного ліворуч золотого знамена на такому ж древку.

V. Яїцький герб: у зеленому полі три срібні гори, на середній втановлена золота булава, на бічних - по золотому бунчуку, у синій основі пливе срібна риба.

VI. Астраханський герб: у синьому полі золота східна корона 3 п'ятьма дугами та зеленою підшивкою, під нею - спрямований вістям праворуч срібний східний меч із золотим руків'ям.

VII. Оренбурзький герб: у червоному полі два скошені навхрест знамена на таких же древках, над ними хрест із нижньою скошеною перемичкою, під ними півмісяць ріжками додолу, всі золоті; у срібній главі синя куниця. 
VIII. Калмицький герб: у синьому полі із золотим бордюром білий (срібний) кречет, навколо якого 9 таких же хвостів яка.

Як бачимо, Гнат Білий не підтримав пропонованого Битинським «розширення» Козакії аж до Тихого океану, тому великий державний герб мав уособлювати союз лише семи козацьких регіонів, як було й на розробленій раніше карті та обкладинці календаряальманаха. Також герби Терека та Астрахані не отримали рекомендованих доповнень булавами.

Наступного року Битинський порушив питання про гімн козацької держави [5, № 80, c. 13-15; № 81, с. 9-12]. Він надав приклади історичного становлення різних національних гімнів i запропонував опрацювати такий самий державний атрибут для Козакії, використовуючи для тексту багату історію козацтва, його особливості як степового войовничого народу, відобразити прагнення до свободи, оспівати боротьбу тощо. Ці заклики спричинилися до кількох публікацій різних варіантів текстів, а також і критики та обговорення цього питання [7, с. 12-14].

Також у часописі було опубліковано нагрудний знак Вільного козацтва, розроблений Миколою Битинським [11, с. 14]. Значок мав становити собою щиток розміром 30x16 мм, на якому був зображений «малий герб Козакії», тобто щит із булавою та бунчками, увінчаний сімома булавами, а під ним - покладені навхрест шабля та гусяче перо, літери «ВК» і дата «1927-10-XI» (іл. 6). Шабля і перо мали символізувати духовні та фізичні сили «на службі своїй землі і державі». Дата вказувала на день заснування часопису «Вільне козацтво» i трактування його як «початок відродження вільнокозацького руху».

В кінці 1932 р. Микола Битинський переглянув пропоновані ним раніше проєкти символів Терського та Калмицького козацтв [9, с. 14-16]. Він звернув увагу, що хоча 3 колишнього герба Терської області й було вилучено зображення двоголового орла, однак кольорове поєднання чорного, срібла та золота нагадує барви російської монархії, тому від терських козаків надходили пропозиції замінити чорне поле на синє. Натомість від калмицької організації «Хальмак Тангчин Тук» надійшли пропозиції вилучити з герба 9 китиць якових хвостів, що мали означати 9 племен у складі колишньої Монгольської імперії часів Чінгізхана, але тепер втратили своє значення, оскільки калмицькі землі будуть входити до складу Козакії. Також пропонувалося дати зображення кречета в польоті, повернутого геральдично ліворуч. На підставі цих побажань і зауважень було зроблено нові варіанти цих гербів.

Оскільки запропоновані зміни стосувалися двох із семи основних земельних гербів Козакії, тому було відкориговано проєкт великого державного герба, який разом із описами опубліковано 1933 р. (іл. 7) [8, с. 13-14]. Також змінено порядок розміщення терського, яїцького, астраханського й оренбурзького гербів, мотивуючи тим, що в новому варіанті вони займають місця не лише за часом виникнення, але й «за більш виразним принципом суміжності їхніх земель із землями інших козацьких військ».

У 1934 р. Гнат Білий переїхав до Парижа, де продовжив видавати часопис «Вільне козацтво». Микола Битинський залишився у Празі і відійшов від активної співпраці 3 вільнокозацьким рухом. Однак його напрацювання й далі використовувалися в часописі, зокрема на тильній стороні обкладинки до останнього числа, яке вийшло 1939 р., публікувалася карта Козакії з великим державним гербом (іл. 8). Ще активніше вживався триколірний синьо-малиново-жовтий прапор. Після Другої світової війни, коли представники Козакії увійшли до складу Антибільшовицького блоку народів, цей прапор публікувався на різних марках (наприклад, на недержавній марці з пам'ятної серії з нагоди 
35-річчя підняття українських прапорів на кораблях Чорноморського флоту (1953р.) [12, c. 129]), плакатах та інших пропагандистських матеріалах. Для Миколи Битинського робота над гербами вільнокозацького руху стала хорошою геральдичною практикою перед його подальшими напрацюваннями, зокрема роботою над проєктами державних символів України [6, с. 144-145]. У Празі була видана монохромна листівка із гербом Козакії. Окрім графічних варіантів Битинський також виконав кольоровий альбом символів козацьких земель.

Додатки:

\section{Ілюстрації:}

1. Обкладинка часопиу «Вольное Казачество - Вільне Козацтво» авторства М. Битинського.

2. Емблема часопису «Вольное Казачество - Вільне Козацтво».

3. Карта Козакії з гербами семи козацьких регіонів (Г. Білий, М. Битинський, 1929 р.).

4. Обкладинка календаря-альманаха на 1930 рік.

5. Проєкт великого державного герба Козакії (1930р.).

6. Проєкт нагрудного знака Вільного козацтва (1932 р.).

7. Відкоригований проєкт великого державного герба Козакії (1933р.).

8. Карта Козакії з великим державним гербом.

\section{Illustrations:}

1. Cover of the magazine "Free Cossacks", designed by Mykola Bytynskyi.

2. Emblem of the magazine "Free Cossacks".

3. Map of Cossackia with the coats of arms of seven Cossack's regions (I. Bilyi, M. Bytynskyi, 1929).

4. Cover of the calendar-almanac (1930).

5. Design of the great state emblem of Cossackia (1930).

6. Draft badge of the Free Cossacks (1932).

7. Corrected design of the great state emblem of Cossackia (1933).

8. Map of Cossackia with a large state emblem.

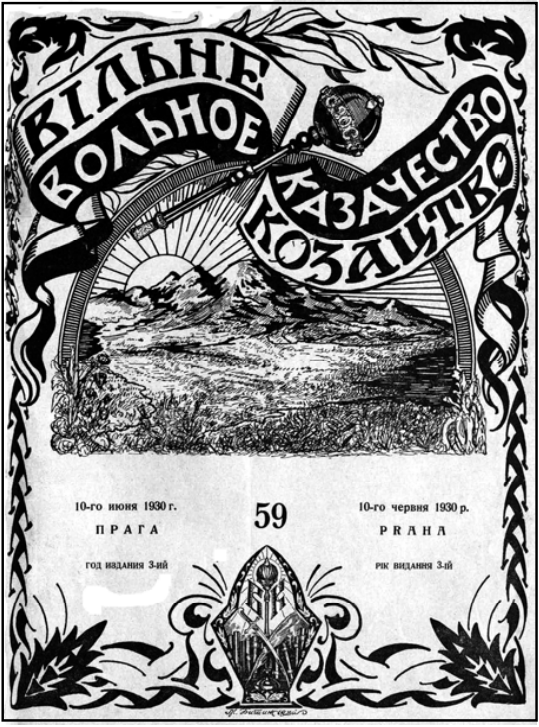

Рис. 1. Обкладинка часопиу «Вольное Казачество - Вільне Козацтво» авторства М. Битинського

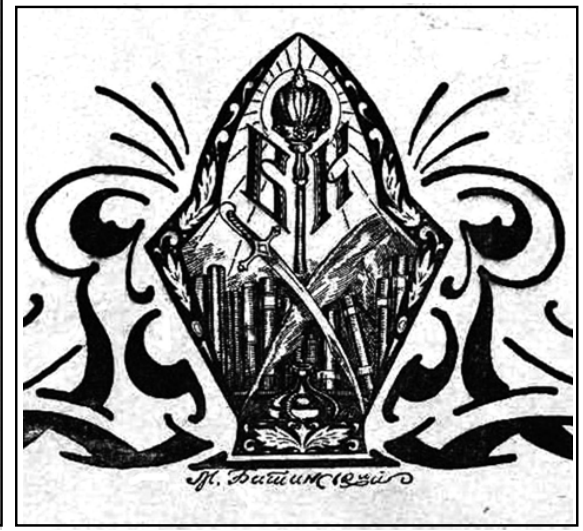

Рис. 2. Емблема часопису «Вольное Казачество - Вільне Козацтво» 


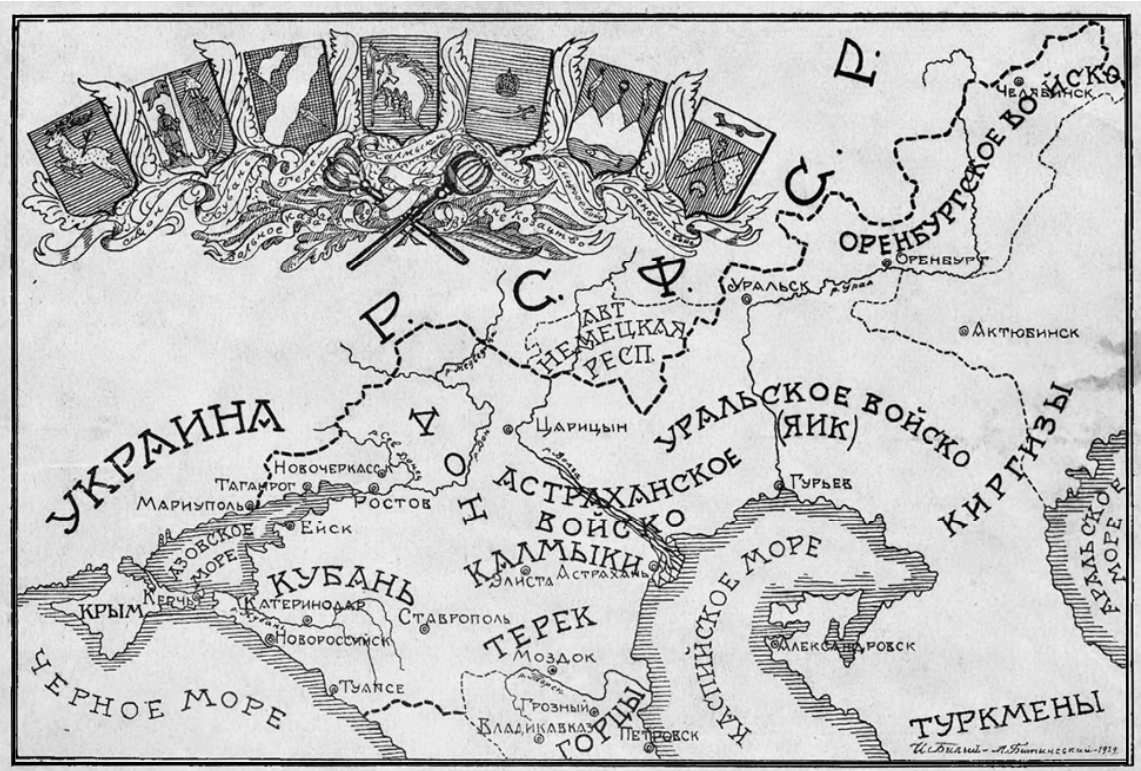

Рис. 3. Карта Козакії з гербами семи козацьких регіонів (Г. Білий, М. Битинський, 1929 р.)

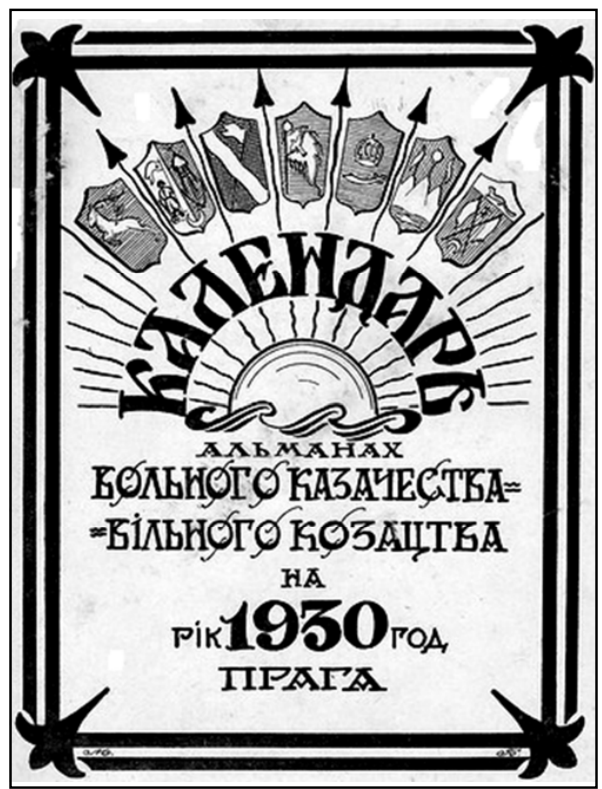

Рис. 4. Обкладинка календаря-альманаха на 1930 рік

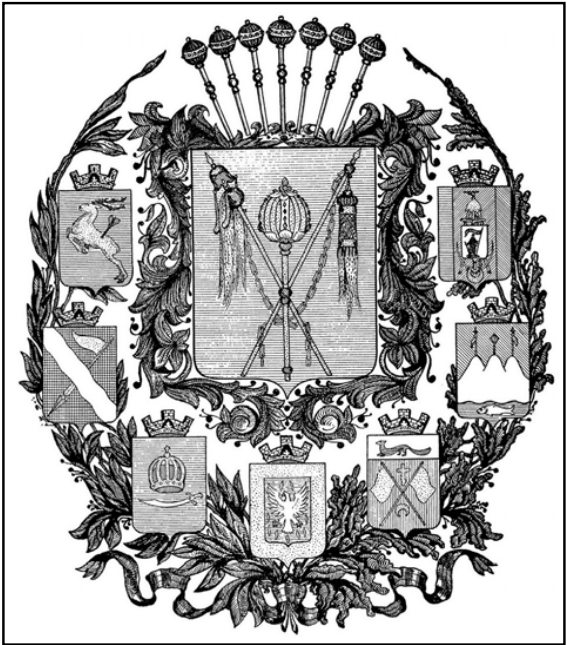

Рис. 5. Проєкт великого державного герба Козакії (1930р.) 

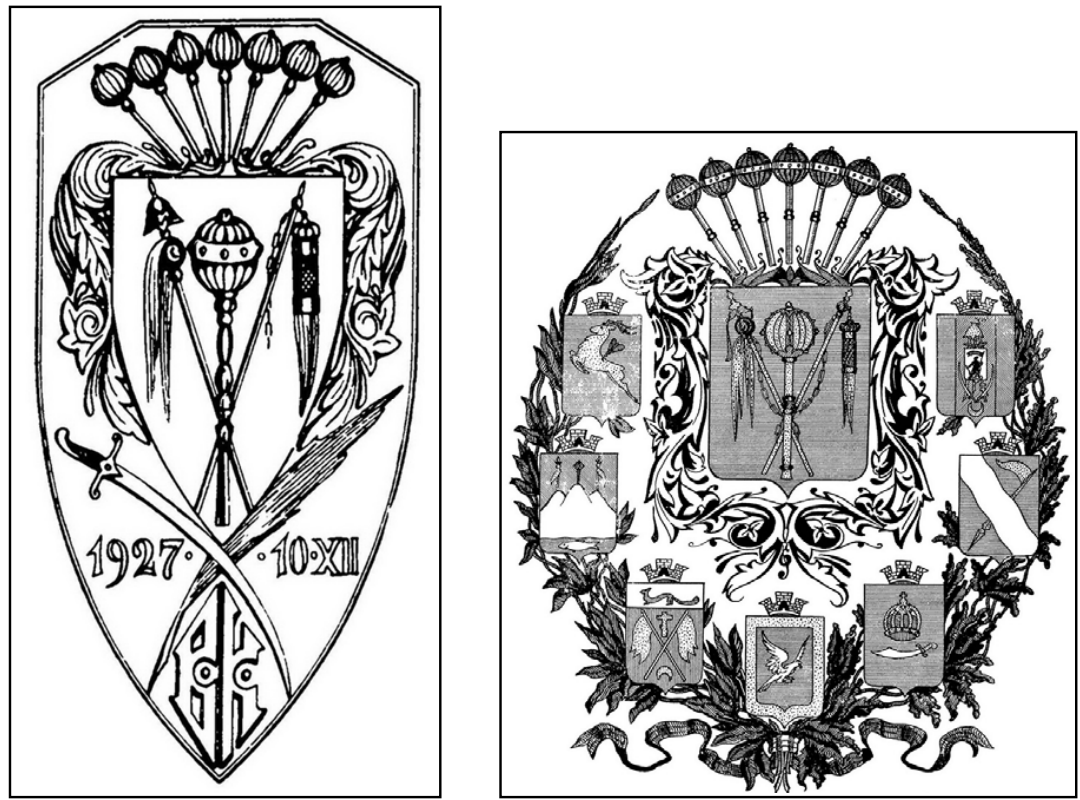

Рис. 6. Проєкт нагрудного знака Вільного

Рис. 7. Відкоригований проєкт великого козацтва (1932 р.) державного герба Козакії (1933 р.)

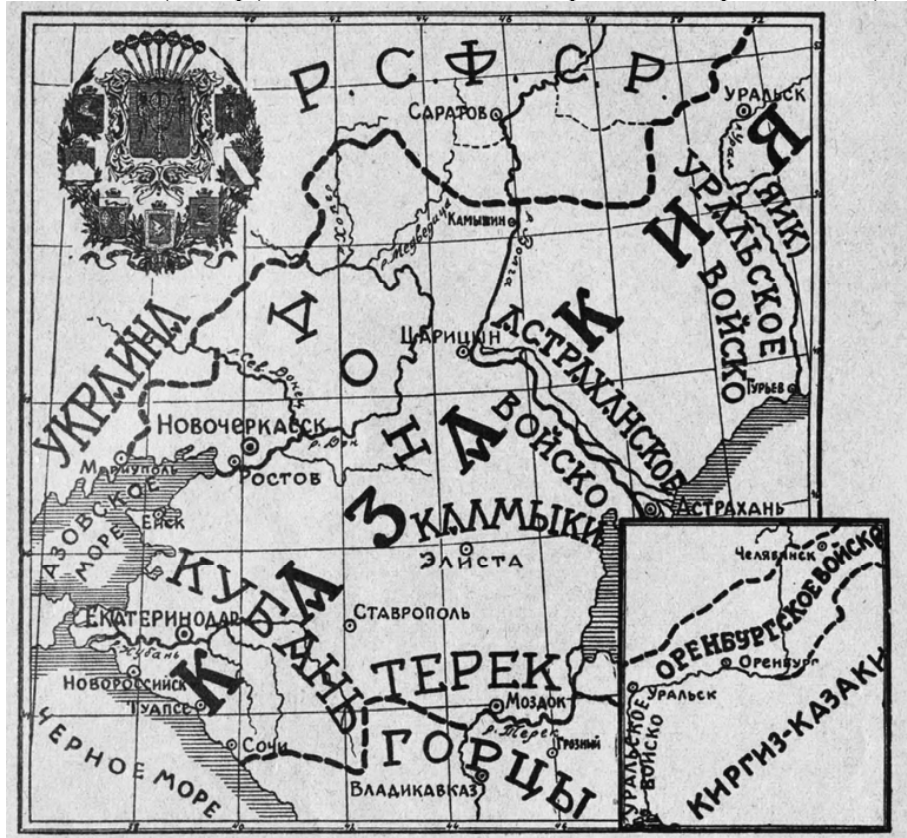

Рис. 8. Карта Козакії з великим державним гербом 


\section{Джерела та література:}

1. Билый И. Казачьи Земли. Территория и народонаселение / И. Билый. - Прага, 1928. - 25 с., карта. (окремий відбиток статей з № 19-23 часопису «Вольное Казачество - Вільне Козацтво»).

2. Битинський М. Плагіят / М. Битинський // Вольное Казачество - Вільне Козацтво. - Прага, 1928. - 25 ноября / листопаду (№ 24). - С. 18-19.

3. Бытынський М. Казачьи гербы / М. Бытынський // Календарь-альманах «Вольного казачества - Вільного козацтва» на 1930 год / рік. - Прага, 1930. - С. 99-129.

4. Бытынський М. Национальные цвета и флаги / М. Бытынський // Вольное Казачество - Вільне Козацтво. - Прага, 1930. - 25 марта / березня (№ 54). - С. 12-14; Бытынський М. Национальные цвета и флаги / М. Бытынський // Вольное Казачество - Вільне Козацтво. - Прага, 1930. 10 апреля/квітня (№ 55). - С. 10-12.

5. Бытынськый М. Гимны / М. Бытынськый // Вольное Казачество - Вільне Козацтво. Прага, 1931. - 10 мая / травня (№ 80). - С. 13-15; Бытынськый М. Гимны / М. Бытынськый // Вольное Казачество - Вільне Козацтво. - Прага, 1931. - 25 мая/травня (№ 81). - С. 9-12.

6. Гречило А. Українська територіальна геральдика. / А. Гречило. - Львів, 2010. - 280 с.

7. И. М. Еще о гимнах / И. М. // Вольное Казачество - Вільне Козацтво. - Прага, 1932. 10 мая/травня (№ 104). - С. 12-14.

8. К пректу Большого Государственного герба Казакии // Вольное Казачество - Вільне Козацтво. - Прага, 1933. - 25 марта / березня (№ 125). - С. 13-14.

9. М. Б. [Бытынський М.] Еще о Терском и Калмыцком гербах / М. Б. [М. Бытынський] //

Вольное Казачество - Вільне Козацтво. - Прага, 1932. - 25 ноября/листопада (№ 117). -

C. 14-16.

10. Оверкович М. Лицарям «Нової Січі» / Микола Оверкович // Вольное Казачество - Вільне Козацтво. - Прага, 1928. - 10 ноября / листопаду (№ 23). - С. 1.

11. Нагрудный (бортовой) знак В. К. // Вольное Казачество - Вільне Козацтво. - Прага, 1932. - 10 мая / травня (№ 104). - С. 14.

12. Підпільна Пошта України / ред. 3. Боровець. - Т. 47 (Літопис Української Повстанської Арміі). - Торонто, Львів, 2009.

13. Флаг и герб Казакии // Вольное Казачество - Вільне Козацтво. - Прага, 1930. - 10 декабря / грудня (№ 70). - С. 15-19.

\section{References:}

1. Bilyi, I., 1928. Kazach'I Zemli. Territoriia I narodonaselenie. Praha. [In Russian]

2. Bytyns'kyi, M., 1928. Pliagiiat. Vol'noe Kazachestvo - Vil'ne Kozatstvo, 24, pp. 18-19. [In Ukrainian]

3. Bytyns'kyi, M., 1930. Kazach'i gerby. Kalendar'-al'manakh "Vol'nogo Kazachestva - Vil'noho Kozatstva" na 1930 god / rik, 1930, pp. 99-129. [In Russian]

4. Bytyns'kyi, M., 1930. Natsional'nye tsveta I flagi. Vol'noe Kazachestvo - Vil'ne Kozatstvo, № 54, pp. 12-14; Bytyns’kyi, M., 1930. Natsional'nye tsveta I flagi. Vol'noe Kazachestvo - Vil'ne Kozatstvo, № 55, pp. 10-12. [In Russian]

5. Bytyns'kyi, M., 1931. Gimny. Vol'noe Kazachestvo - Vil'ne Kozatstvo, № 80, pp. 13-15; Bytyns'kyi, M., 1931. Gimny. Vol'noe Kazachestvo - Vil’ne Kozatstvo, № 81, pp. 9-12. [In Russian]

6. Grechylo, A., 2010. Ukrains 'ka terytorial'na heral'dyka. L'viv. 280 p. [In Ukrainian]

7. I. M., 1932. Eshche o gimnakh. Vol'noe Kazachestvo - Vil'ne Kozatstvo, № 104, pp. 12-14. [In Russian]

8. K proektu Bol'shogo Gosudarstvennogo gerba Kazakii, 1933. Vol'noe Kazachestvo - Vil'ne Kozatstvo. Praha, № 125, pp. 13-14. [In Russian]

9. M. B. [Bytyns'kyi M.], 1932. Eshche o Terskom I Kalmytskom gerbakh. Vol'noe Kazachestvo Vil'ne Kozatstvo, № 117, pp. 14-16. [In Russian]

10. Overkovych, M., 1928. Lytsariam «Novoi Sichi». Vol’noe Kazachestvo - Vil’ne Kozatstvo, № 23, p. 1. [In Ukrainian] 
11. Nagrudnyi (bortovoi) znak V. K., 1932. Vol’noe Kazachestvo - Vil’ne Kozatstvo, № 104, p. 14. [In Russian]

12. Borovets, Z. ed., 2009. Pidpil'na Poshta Ukrainy, Vol 47 (Litopys Ukrains'koi Povstans'koi Armii). Toronto, L'viv. [In Ukrainian]

13. Flag I gerb Kazakii, 1930. Vol'noe Kazachestvo - Vil'ne Kozatstvo, № 70, pp. 15-19. [In Russian]

Отримано: 04.12.2020 p. 
ISSN 2519-2523 (print)

Chornomors'ka mynuvshyna. - 2020. - No.15

DOI: $10.18524 / 2519-2523.2020 .15 .218683$

УДК 94 (477)

\title{
PRESENTATIONS OF THE HISTORY OF RIGHT-BANK AND LEFT-BANK UKRAINE IN MODERN REGIONAL AND HISTORICAL TEXTS: POSING THE PROBLEM
}

\author{
Liyudmyla Novikova \\ ORCID: https://orcid.org/0000-0003-4764-7867 \\ $\mathrm{PhD}$ (History), Associate Professor \\ Odessa I. I. Mechnikov National University \\ 2, Dvoryanska Str., Odessa, 65082, Ukraine \\ lyudmilanovikova@hotmail.com
}

Despite the development in modern historical science of such areas as historical local history and historical regional studies, the specifics of the historiographic presentation of Ukrainian regions in the modern period remains insufficiently studied. In this study, an attempt was made to determine the complex structure of historiographic interpretations of Left-Bank and Right-Bank Ukraine in modern times, which coexisted and were manifestations of transformations of social identity, to outline this issue as a separate scientific problem in the field of historical regional studies. It was found that historiographical presentations of the history of Right-bank and Left-Bank Ukraine in the XIX - early XX century had a complicated structure. The history of the Right Bank (or its subregions) was included in the context of "Western-Russian" history, the history of the western part of the Russian Empire, the Polish concept of "oriental kreses", as well as the paradigm of national Ukrainian history. The latter also experienced transformation, in particular, from the history of Kievian land and South-Western Russia, Little Russia to the history of Ukraine itself. In this regard, in the late XIX century, there were works specifically devoted to the history of "RightBank Ukraine".

A similar evolution is experienced by the presentation of the history of the Left-Bank Ukraine (its subregions). At the same time, there was also its own specificity, determined by the fact that it was the territory of the former Left-Bank Hetmanate. As a result, there was such a presentation of the history of the region as the history of the Cossack regiments (as administrative territories).

At the same time, there is a tendency at the edge of the XIX and XX centuries to consider the history of the region as the history of "Left-Bank Ukraine". The question of how the history of LeftBank Ukraine was reflected in the context of the "West-Russian" concept remains open, although its reflection is present in the related regional ("oblast" or "land") one.

Key words: historiographic interpretations of the history of Left-Bank Ukraine in modern times; historiographic interpretations of the history of Right-Bank Ukraine in modern times; "Western-Russia"n historiographic concept; paradigm of national Ukrainian history.

Людмила Новікова

ORCID: https://orcid.org/0000-0003-4764-7867

Кандидат історичних наук, доцент Одеський національний університет імені I.I. Мечникова Вул. Дворянська, 2, Одеса, 65082, Україна lyudmilanovikova@hotmail.com 


\section{ПРЕЗЕНТАЦІЇ ІСТОРІЇ ПРАВОБЕРЕЖНОЇ ТА ЛІВОБЕРЕЖНОЇ УКРАЇНИ В МОДЕРНИХ РЕГІОНАЛЬНО-ІСТОРИЧНИХ ТЕКСТАХ: ДО ПОСТАНОВКИ ПРОБЛЕМИ}

Незважаючи на розвиток у сучасній історичній науці таких напрямків, як історичне краєзнавство та історична регіоналістика, недостатньо вивченим залишається специфіка історіографічної презентації українських регіонів у модерний період. У даному дослідженні здійснена спроба визначити складну структуру історіографічних інтерпретацій історії Лівобережної та Правобережної Украӥни в модерну добу, щзо співіснували й були проявами трансформацій суспільної ідентичності, окреслити це питання як окрему наукову проблему в галузі історичної регіоналістики.

Було встановлено, що історіографічні презентації історії Правобережної та Лівобережної України у ХIX - на початку XX cm. мали складну структуру. Історія Правобережжя (або його субрегіонів) включалася в контекст «західноруської》 історії, історії західної частини Російської імперї, польської концепції «східних кресів», а також до парадигми національної украӥнської історії. Остання теж переживала трансформацію, зокрема, від історії Київської землі та Південно-Західної Русі, Малоросії до власне історії України. У зв'язку з ичим наприкінці XIX cm. з'являються праціi, спеціально присвячені історії «Правобережної України».

Подібну еволючію переживає і презентація історії Лівобережжя (його субрегіонів). Водночас тут була й своя специфіка, визначена тим, щчо це була територія колишньої Лівобережної Гетьманщини, внаслідок чого наявна така презентація історії регіону як історії полків. Водночас спостерігається тендениія до переходу на межі XIX-XX cm. до розгляду історії регіону власне як історї «Лівобережної Украӥни». Відкритим поки що залишається питання те, як історія Лівобережної України відображалася в контексті «західноруського» підходу, хоча вона і висвітлювалася в контексті пов'язаної, на наш погляд, з ичи підходом обласної (земельної) концепції.

Ключові слова: історіографічна інтерпретація історії Лівобережної Украӥни в модерний період; історіографічна інтерпретація історії Правобережної України в модерний період; «західноруська» конщепція; парадигма національної історії Украӥни.

Незважаючи на розвиток у сучасній історичній науці таких напрямків, як історичне краєзнавство та історична регіоналістика, недостатньо вивченим залишається специфіка історіографічної презентації українських регіонів у модерний період. Зокрема, це стосується Правобережної та Лівобережної України. Хоча дослідження історії вивчення Правобережжя та Лівобережжя має помітну історіографію, представлену працями Л. В. Баженова, С. Е. Баженової, О. І. Журби, О. Коваленко та ін. [1-5], однак, на наш погляд, існує потреба більш докладного висвітлення питання щодо співіснування в умовах Російської імперії різних інтерпретацій історії регіону, що мали національний характер.

Мета даного дослідження - обгрунтувати наявність складної структури історіографічних інтерпретацій історій вказаних регіонів в модерну добу, що співіснували й були проявами трансформацій суспільної ідентичності, окреслити це питання як окрему наукову проблему в галузі історичної регіоналістики.

Презентації історії Правобережної України. Однією $з$ форм історіографічної презентації історії Правобережної України в Російській імперії було висвітлення регіональної або відповідної предметної історії у контексті «західноруської» концепції, тобто крізь призму наративу щодо розколу території колишньої Русі, відділення різними країнами «Західної Русі» та згодом іiі «повернення» до складу Російської імперії, яка в офіційній імперській історіографії розглядалася як спадкоємиця Русі. 
Праці, засновані на використанні цієї концепції, відповідали так званому «антидотному» («антиотрутному») напрямку політичної літератури, що існував у Російській імперії з другої половини XVIII ст., 3 метою виправити «неправильні» уявлення щодо імперії, які поширювалися в Європі. Подібний характер мала й «записка» «Взгляд на историю Западной Руси» (СПб., 1848) [6]. Автор висловлював думку, що історики до початку XIX ст. подавали спільну історію Русі тільки до XII ст., як Нестор-літописець, а потім зосереджувалися на історії східної Русі (Московської держави), ігноруючи історію Західної Русі. Це сформувало невірні уявлення щодо «найважливішої частини руської історії, яка залишалася без пояснення» (тут і далі переклад українською автора статті) [6, с. V], тобто уявлення про відношення «Західної Русі» до Польщі. Внаслідок відсутності подібної інформації поширюється співчуття польському рухові в Свропі [6, с. VII]. Особливу увагу автор «записки» приділяє подіям в «Південній частині Західної Русі» в Речі Посполитій, ролі козацтва, яке займало територію, що спершу називалася Україною, а згодом Малою Росією [6, с.17]. Подібна концепція властива монографії М. Кояловича «Чтения по истории Западной России» (1884) [7].

Отже, відповідно цій концепції, історія Правобережжя мала бути вписана в контекст історії Південно-Західної Русі (тобто територіально України). Представляє інтерес те, що адміністративно-територіальна термінологія поширювала поняття «Південно-Західного краю» саме на три губернії переважно Правобережної України, хоча $з$ історіографічної точки зору даного кола авторів, як можна дійти висновку, це мала бути вся Україна за межами «Східної Русі».

У певному зв'язку 3 «західноруськими» працями знаходяться видання, присвячені західній частині Російської імперії, які видавалися МВС з 1858 р. Згодом, у 1887-1890 pр., до 900-річчя хрещення Русі виходить серія під загальною назвою (в інтерпретації її видавця К. Батюшкова) «Памятники русской старины в западных губерниях» Російської імперії. Вона, зокрема, включала нариси, присвячені «Волині» та «Поділлю». Отже, історія Правобережної України розглядалася і в контексті історії західної части Російської імперії. Історія Поділля, наприклад, в очах видавця підтверджувала те, що Поділля, «населене з давніх часів слов'яно-руським племенем, довго знаходилося під чужоземним ігом, не втратило особливостей землі руської», що у XVIII ст. «повернулася до Росії» [8, с. XI-XII]. Поряд 3 конкретним ідеологічним завданням, книги серії включали багатий фактичний матеріал, ілюстрації місцевих памяток, портрети світських та церковних діячів та ін. У виданні з історії Волині його автор, М. І. Петров, поставив мету «...вміщувати тільки такі події з життя Волині, які сприяли чи перешкоджали розвитку руської народності та православ'я» [9, с. 4].

Важливий крок у напрямку до вироблення національної концепції української історії зробив М. О. Максимович, який пропагував концепцію «Київської землі» (України). Певне підтвердження такого ставлення М. О. Максимовича до «Київської землі» знаходимо у його роздумах щодо можливості перетворення альманаха «Киевлянин» в спеціальний журнал, що мав би виходити 6 книгами на рік. Міркуючи про нове видання, М. О. Максимович говорить про можливість назвати його якщо не «Киевлянин», «...то «Украинским зрителем» или «Малороссийскою скрынею»...» (у своєму листі до Й. М. Бодянського, 18 квітня 1857 р.) [10, с. 47].

Коментарі М. О. Максимовича 3 приводу історії Правобережжя нагадують принципові положення «західноруського» підходу. Водночас його концепція «Київської землі» відкриває шлях до розуміння регіональної історії в українському контексті. Зокрема, у своєму листі до Д. Г. Бібікова у 1884 р. $з$ приводу актів 
Луцького братства він відзначав: «Акти ці істинно дорогоцінні, бо представляють собою нове свідчення про те, з яким старанням і якими засобами Волинська Русь оберігала у минулі часи православну віру, яка складає основну й головну стихію народності нашої, для якої ціла Русь стільки віків жила та діяла» [10, с. 21].

3 іншого боку, формується напрямок так званої обласної (земельної) історії, представники якого зосереджуються на самобутньому періоді історії окремих земель Русі до XIV ст., коли вони включаються до складу Польщі, Литви та ін. Останній напрямок часто пов'язується з В. Б. Антоновичем та представниками його київської історичної школи. Водночас не слід виключати вплив на формування обласного чи земельного напрямку «західноруської» концепції, яка проводила чітку лінію між історією Русі до та після входження ії̈ земель до Литви та Польщі у XIV ст. Одним 3 прикладів є праця П. А. Іванова «Судьбы Волынской земли с древнейших времен до конца XIV века» (1895) [11].

Історія Правобережної України в польській історіографії часто розглядалася як історія «східних кресів» (окраїн) Речі Посполитої. Це було властиво для істориків краківської історичної школи та пов'язаної з нею «української історичної школи» в польській історіографії [2, с. 10-11], представником якої був Ю. А. Роллє (Кам'янецьПодільський). Він 31876 р. до 1893 р. опублікував дев'ять серій «Історичних оповідей», що стосувалися історії Правобережної України, а також інші збірки. Серед останніх ілюстративною є збірка під назвою «Наречені кресів, історичні оповіді» (1883) [3]. Ми згадуємо праці Ю. А. Роллє з огляду на те, що вони мали високу історичну вартість завдяки унікальному джерельному матеріалу, використаному для їх написання, а його внесок у висвітлення історії регіону був визнаний з боку істориків-сучасників.

Історія регіону як власне історія Правобережної України розглядається як специфічний предмет вже в умовах розвитку української етнічної історіографії, як окремого історіографічного напрямку. Прикладом є робота О. Я. Єфименко «Очерки истории Правобережной Украины» (К., 1895) [13], написана на основі праць Ю. А. Роллє, присвячених історії регіону. Водночас слід відзначити, що термін «правобережна Україна» зустрічається і у більш ранніх працях, зокрема, в роботі М. О. Домонтовича, коли він звертається до опису одного 3 повстань першої половини XVII ст. [12, с. XII].

Визнаючи великий внесок Ю. А. Роллє у вивчення історії Правобережної України, О. Я. Єфименко практично визначає концептуальне значення його праць, хоча пізніше, дещо суперечливо зі спробою окреслити роботи Ю. А. Роллє як частину предметної української історіографії, у самої О. Я. Єфименко виходить збірка досліджень з історії України під назвою «Южная Русь» (як Україна) [14].

Авторка «Очерков» відтворює оригінальну картину загальної історії Правобережної України, починаючи з історії субрегіонів, що іiі складали: Волині, Побужжя, Київське Полісся, Подністров'я. О. Я. Єфименко звертає увагу на демографічні процеси в регіоні, виділяючи області «початкового старо-руського заселення» та нового. Вона стежить за суспільними відмінностями в історії субрегіонів, що залежали від дії різних чинників, формували різні суспільні типи [14, c. 3-4]. Зокрема, дослідниця відзначає, що на Волині та Київському Поліссі «руський елемент розвивався повністю самостійно, без впливу якихось однобічних впливів», а у Подністров'ї відчувався сильний польський вплив [14, с. 5, 8], Представляє інтерес певна антипольська спрямованість тексту О. Я. Єфименко, що, однак, була пов'язана зі співчуттям до становища українців, а не була визначена спробою пояснити 
входження Правобережжя до Російської імперії [14, с. 151]. Певна увага в «Очерках» приділяється історичній психології на Правобережжі [14, с.163], що детерміновано, очевидно, тим матеріалом, 3 яким, як 3 джерелом, працювала О. Я. Єфименко роботи Ю. А. Роллє були роботами не тільки краєзнавця, але й лікаря-психіатра.

Окремою формою презентації історії Правобережної України були церковноісторичні дослідження, історико-статистичні описи єпархій, в яких предметна структура охоплює як світську, так і церковну історію, з домінуванням останньої. Як приклад, слід згадати про розвідку М. І. Теодоровича «Историко-статистическое описание церквей и приходов Волынской епархии» (у 5 тт., Почаєв, 1888-1903). Автор зазначив, що присвячує свою працю поборникам «Православ'я та руської народності на Волині». Волинь він розглядає в межах єпархії, а також як одну 3 західноруських областей. У першому томі М. І. Теодорович викладає «Короткий нарис історії Волині». Звертаючись до середньовіччя, автор вказує на те, що у східній частині Волині проживали древляни, в західній та Галичині - волиняни/бужани, простежує підкорення Волині та Галичини князям Русі, історію «знаменитого Галицько-Волинського князівства або королівства Даниїла» [15, с.10]ю Останнє він розглядає як «давню власність Росії, набуту зброєю Олега та святого Володимира» що була розділена «між чужоземцями», втративши після приєднання галицьких князів до Польщі свою незалежність назавжди. Звертаючись до питання поширення на Волині християнства, автор вказує на те, що вона була однією з перших руських земель, де поширилось християнство. Згадуючи про гіпотезу щодо ролі в цьому моравського просвітника Мефодія, Теодорович певним доказом цього ввапжає те, що занепад Моравської держави супроводжувався еміграцією християн [15, с. 14-15]. Автор наводить переліки та біографічні дані православних єпископів в єпископських центрах Володимирі, Луцьку, а також - у примітках - переліки місцевих уніатських єпископів. Значну увагу автор приділяє церковно-релігійній історії, вказуючи на те, що «Литва не притісняла, а засвоювала руську народність» [15, с. 22], а поляки, фанатично переслідуючи руську мову і взагалі руську народність, «робили руську людину поляком» [15, с. 24]. Тому автор високо оцінює 1793 р., як «кінець святкуванню ворогів православ'я» [15, с. 24], трактуючи приєднання Волині та Правобережжя як «повернення» давньої власності, вказує на масове навернення до православ'я наприкінці XVIII ст. [15, с. 24-25]. Таким чином, погляди М. I. Теодоровича співвідносяться 3 поглядами прибічників «західноруської» історіографічної концепції.

Окремо слід відзначити, що представники різних історіографічних напрямків, згаданих вище, часто формували уявлення щодо історії Правобережної України як історії історично православного регіону.

Особливості презентації історії Лівобережної України. Іспорія Лівобережної України активно висвітлювалася представниками обласного (у розумінні земельного) історіографічного напрямку. У поле зору дослідників при цьому потрапляли окремі субрегіони, такі, як історична «Сіверська земля». Зокрема, слід згадати дослідження Д. І. Багалія «История Северской земли до половины XIV ст.» (1882) [16]. Тим самим історія Лівобережної України (або іï субрегіони) поставали як складові середньовічної Русі.

Окремо слід згадати про представлення історії Лівобережної України у вигляді історії іiі субрегіонів, визначених в межах адміністративно-територіального поділу, зокрема, губерній. (Чернігівської, Полтавської, зокрема), Прикладом є офіційні дослідження, здійснені офіцерами генерального штабу, зокрема, М. О. Домонтовича [12]. 
М. О. Домонтович починає історію губернії задовго до їі офіційного створення і доводить ії до 1808 р.. коли після створення у 1802 р. Чернігівської губернії було завершено створення іiі повітів. 3 цього часу, відзначає автор, «історія іiі (Чернігівської губернії) стає нероздільною з історією Російської [у автора - Русской] імперії» [12, c. XXI]. Практично історія губернії є історія населеної місцевості, яка входить у межі губернії. Автор починає з часів заселення території слов'янами, згадуючи версію Нестора-літописця щодо переселення їх з Дунаю. Далі він виходить за межі губернії, звертаючись до долі історичних Сіверської землі, Чернігівського уділа. Так, згадуючи про підпорядкування Сіверської землі Києву, він відзначає, що далі був період 160річної спільної історії, а самостійне життя уділу почалося зі Святослава Ярославича. При цьому автор вказує на розміри Чернігівського уділу, які виходили далеко за межі Чернігівської губернії, включаючи частини білоруських та російських губерній, сучасних автору $[12$, с. II, IV]. М. О. Домонтович висвітлює історію громадянськості (суспільства), визначає значення кожного наступного періоду, включно 3 періодом Гетьманщини. Автор вказує на позитивне значення для регіону перебування його під владою Литви - були відсутні перепони для розвитку місцевої громадянськості тощо [12, с. VIII], намагається пояснити значення для регіону періоду перебування в Московському царстві, негативно оцінює політику Польщі, направлену на знищення «південно-руської громадянськості» [12, с. ХІІ]. Особливістю роботи є те, що іноді брак конкретного регіонального матеріалу М. О. Домонтович заповнює загальною історичною концепцією.

Історія Чернігівщини часто розглядається в сукупності з історією Чернігова, виступаючи своєрідним історичним тлом для історії міста. Тут ми зустрічаємося, очевидно, 3 існуванням своєрідного «протографу» такого підходу, коли існував початковий подібний текст, а далі вже дослідники «успадковували» вже існуючий підхід. 3 цим ми зустрічаємося у вже згаданій праці М. О Домонтовича, а також пізніше, вже на початку XX ст., у ювілейній роботі, присвяченій тисячолітній історії м. Чернігова [17].

Окремим видом презентації місцевої історії $є$ історія єпархії, зокрема, в праці архієпископа Філарета Гумілевського «Описание Черниговской епархии» (Чернігів, 1873 р., у 5 книгах).

Особливим напрямком висвітлення історії Лівобережної України було зображення iї як історії Гетьманщини. У зв'язку з цим слід згадати працю О. М. Лазаревського «Описание старой Малороссии», який пропонує бачення історії Лівобережжя як історії українських адміністративно-територіальних одиниць - полків [18]. О. М. Лазаревський називає територію колишньої Гетьманщини Малоросією, тобто вживає цей термін у даному випадку у вузькому значенні, а не як синонім України. У передмові до свого кількатомного видання О. М. Лазаревський відзначав, що у його праці дається опис «Малоросії лівого берега Дніпра», що тепер складає Чернігівську та Полтавську губернії. Зустрічається у історика й термін «Лівобережна Україна» [19, с. 1-5].

Своїм завданням дослідник ставив опис всіх 10 полків Лівобережної Гетьманщини, «вважаючи, що наша книга дасть певні матеріали для вивчення народного життя, яке у написаних дотепер історіях Малоросії так сильно заслонена переказом подій зовнішньої історії» [18, с. III]. Хронологічні межі своєї праці О. М. Лазаревський визначав від «...приєднання Малоросії до руської держави у 1654 р. до введення в ній загальноросійських [у автора - «общерусских»] форм громадянського управління у 1782 р...». Дослідник встиг видати, крім першого, томи, 
присвячені історії Ніжинського (1893), Прилуцького полків (1902). Опис кожного полку О. М. Лазаревський починав «історичним нарисом місцевості, на якій розташований полк» $[19$, с. 1$]$.

На питаннях внутрішньої, соціальної історії Гетьманщини зосереджував увагу учень Д. І. Багалія В. О. Барвінський у своїй розвідці, вміщеній у «Записках НТШ» українському загальнонаціональному у свій час науковому виданні - під назвою «До історії закріпощення селян в Лівобічній Україні» [20, с. 154-157, Miscellanea]. Під останньою автор має на увазі Гетьманщину. Автор звертається до історії суспільного життя на Україні, вказує на закономірність появи явища кріпацтва, властивого різним країнам (вплив марксизму?). В. О. Барвінський простежує еволюцію інтересів, появу конфлікту між «поспольством» та державцями (вже на кінець XVII ст.), вважає кріпосне право результатом внутрішнього розвитку Гетьманщини [20, с. 155].

Інша стаття В. О. Барвінського у «Записках НТШ» присвячена також питанням внутрішньої історії «Лівобережної України», «Лівобережжя». Автор публікує документи 3 Румянцевського опису, присвячені «...малодослідженій соціяльно-економічній історії лівобережної України» [21, с. 25], а саме питанням землеволодіння, скуповуванню козацької землі, яке В. Барвінський характеризує як невпинне суспільне явище в регіоні, незважаючи на діючий заборонний указ 1739 р., кредитній активності представників козацтва тощо [21, с. 26-28].

Отже, історіографічні презентації історії Правобережної та Лівобережної України у XIX - на початку XX ст. мали складну структуру. Історія Правобережжя (або його субрегіонів) включалася в контекст «західноруської» історії, історії західної частини Російської імперії, польської концепції «східних кресів», а також до парадигми національної української історії. Остання теж переживала трансформацію, зокрема, від історії Київської землі та Південно-Західної Русі, Малоросії до власне історії України. У зв'язку з цим наприкінці XIX ст. 3'являються праці, спеціально присвячені історії «Правобережної України». Подібну еволюцію переживає i презентація історії Лівобережжя (його субрегіонів). Водночас тут була й своя специфіка, визначена тим, що це була територія колишньої Лівобережної Гетьманщини, внаслідок чого наявна така презентація історії регіону як історії козацьких полків. Водночас спостерігається тенденція до переходу на межі XIXXX ст. до розгляду історії регіону власне як історії «Лівобережної України». Відкритим залишається питання те, як історія Лівобережної України відображалася в контексті «західноруського» підходу, хоча вона й висвітлювалась в контексті пов'язаної, на наш погляд, з цим підходом обласної (земельної) концепції .

\section{Джерела та література:}

1.Баженов Л. В. Історичне краєзнавство Правобережної України XIX - на. початку XX ст. Становлення. Історіографія. Біобібілографія./ Л. В. Баженов. - Хмельницький, 1995. - 255 с.

2. Баженов Л. В. Регіональна історія України в дослідженнях краківської історичної школи (60-ті pр. XIX ст. - початок XX ст.) / Л. В. Баженов // Вісник Кам'янець-Подільського національного університету ім. І. Огієнка. Історичні науки. - 2016. - Вип. 9. - С. 8-16.

3. Баженова С. С. Юзеф Антоній Роллє: життя, діяльність, творчість. 2-е видання. / С. Є. Баженова. - Кам'янець-Подільський, 2002. - 180 с.

4. Журба О. І. Київська археографічна комісія, 1843-192: нарис історії і діяльності./ О. І. Журба. - Київ: Наук. думка, 1993. - 184 с.

5. Коваленко О. Головні етапи розвитку історичного краєзнавства на Чернігово-Сіверщині /

О. Коваленко // Краєзнавство. - 2000. - № 1. - С. 39-45.

6. Взгляд на историю Западной Руси. - СПб., 1848. - VIII - 65 с. 
7. Коялович М. И. Чтения по истории Западной России. / М. И. Коялович. - СПб.: Тип. А. С. Суворина, 1884. - XIII, [3]. - 349 с.

8. Петров Н. И. Подолия. Историческое описание / Н. И. Петров. - СПб., 1891. - 401 с.

9. Петров Н. И. Волынь. Исторические судьбы Юго-Западного края. / Н. И. Петров. - СПб., 1888. - 438 c.

10. Максимович М. Листи / М. Максимович. - Київ: Либідь, 2004. - 312 с.

11. Иванов П. А. Судьбы Волынской земли с древнейших времен до конца XIV века / П. А. Иванов. - Одесса, 1895. - 328 с.

12. Домонтович М. Материалы для географии и статистики России, собранные офицерами Генерального штаба. Черниговская губерния / М.Домонтович. - СПб.: Тип. Ф. Персона, 1865. $796 \mathrm{c}$.

13. Ефименко А. Я. Очерки истории правобережной Украины. / А. Я. Ефименко. - Киев: Тип. Г. Т. Корчак-Новицкого, 1895. - 2, 174 с.

14. Ефименко А. Я. Южная Русь: очерки, исследования, заметки: в 2 т. / А. Я. Ефименко. СПб.: Книгопечатня Шмидта, 1905. - Т. 1. - 439 с.

15. Теодорович Н. И. Историко-статистическое описание церквей и приходов Волынской епархии. / Н. И. Теодорович - Почаев, 1888. - Т. 1. - 432, IV с.

16. Багалей Д. История Северской земли до половины XIV ст. Историческая монография. / Д. Багалей. - Киев, В университетской типографии (И.И.Завадского), 1882. - I, 310, [2], II с.

17. Очерк истории города Чернигова, 907-1907: юбил. изд. Чернигов. Гор. Управы. Чернигов: Тип. Губ. Земства, 1908. - 71 с.

18. Лазаревський А. М. Описание старой Малороссии. Т. 1.: Полк Стародубский. / А. М. Лазаревський. - К., 1888. - XVI, 470, XXX с.

19. Лазаревский А. М. Описание старой Малороссии. Т. 2.: Полк Нежинский. / А. М. Лазаревський. - К., 1893. - IV, 521, XXV с.

20. Барвінський В. До історії закріпощення селян в Лівобічній Україні / В. Барвінський // Записки НТШ. - 1908. - Т. 81. - Кн. 1.- С. 154-155. Miscellanea.

21. Барвінський В. Матеріали до історії суспільному та економічного побуту Лівобережної України в XVIII ст. / В. Барвінський // Записки НТШ. - 1909. - Т. 90. - Кн. 4.- С. 25-32.

\section{References:}

1. Bazhenov, L. V., 1995. Istorychne kraieznavstvo Pravoberezhnoi Ukrainy XIX-na pochatku XX st. Stanovlennia. Istoriografiia. Bibliografiia [Historical local history of the Right-Bank Ukraine in the XIX - at early XX century. Formation. Historiography. Biobibilography]. Khmel'nytsky. [in Ukrainian].

2. Bazhenov, L. V., 2016. Regionalna istoriia Ukrainy v doslidjenniakh krakivs'koi istorychnoi shkoly (60-ti rr. XIX st. - pochatok XX st.) [Regional history of Ukraine in the research of Krakow Historical School (60's of the XIX c. - early XX c.)]. Visnyk Kam'yanets'-Podil's'kogo natsionalnogo universitetu im. I. Ogienka. Istorychni nauky, 9, pp. 8-16. [in Ukrainian].

3. Bazhenova, S. Ye., 2002. Yuzef Antonii Rollie: zhyttia, diial'nist', tvorchist' [Josef Anthony Rolle: life, activities, creativity] 2nd. Kam'yanets'-Podil's'kyi. [in Ukrainian].

4. Zhurba, O. I., 1993. Kyivs'ka arkheografichna komissiia, 1843-1921: narys istorii i diial'nosti [Kyiv Archeographical Commission, 1843-1921: essay of history and activity]. Kyiv: Naukova dumka. [in Ukrainian].

5. Kovalenko, O., 2000. Golovni etapy rozvytku istorychnogo kraieznavstva na ChernigovoSiverschyni [The main stages of development of historical local history in Chernihiv-Siverschyna]. Kraieznavstvo, 1., pp. 39-45. [in Ukrainian].

6. Vzgliad na istoriiu Zapadnoi Rusi [A look at the history of Western Russia], 1848. SPb. [in Russian].

7. Koialovich, M. I., 1848. Chtieniia po istorii Zapadnoi Rossii [Readings on the history of Western Russia]. SPB.: Tip. A. S. Suvorina. [in Russian]. 
8. Petrov, N. I., 1891. Podoliia. Istoricheskoie opisaniie [Podolia. Historical description]. SPb. [in Russian].

9. Petrov, N. I., 1888. Volyn'. Istoricheskiie sud'by Yugo-Zapadnogo kraia [Volyn. Historic fates of the South-West region]. SPB. [in Russian].

10. Maksymovych, M., 2004. Lysty [Letters]. Kyiv: Lybid'. [in Ukrainian].

11. Ivanov, P. A., 1895. Sud'by Volynskoi zemli s drievniejshykh vremion do kontsa XIV veka [The fate of Volyn Land from ancient times to the end of the 14th century]. Odessa. [in Russian]

12. Domontovich, M., 1865. Matierialy dlia geografii i statistiki Rossii, sobrannyie ofitserami General'nogo shtaba.Chernigovskaia guberniya [Materials for the geography and statistics of Russia, collected by officers of the General Staff. Chernigov Province]. SPb.: Tip. F. Persona. [in Russian].

13. Yefimenko, A. Ya., 1895. Ocherki istorii pravobierezhnoi Ukrainy [Essays of the history of the Right Bank Ukraine]. Kiev: Tip. G. T. Korchak-Novitskogo. [in Russian].

14. Yefimenko, A. Ya., 1905. Yuzhnaia Rus': ocherki, issliedovaniia, zametki [Southern Russia: essays, research, notes]: v 2 t. Vol. 1. SPb.: Knigopechatnia Shmidta. [in Russian].

15. Tieodorovich, N. I., 1888. Istoriko-statisticheskoie opisaniie tserkviei i prikhodov Volynskoi yeparkhii [Historical and statistical description of churches and parishes of the Volyn diocese]. Vol. 1. Pochaiev. [in Russian].

16. Bagaliei, D., 1882. Istoriia Severskoi ziemli do poloviny XIV st. Istoricheskaia monografiia [History of the Severskaia Land up to half of the XIV c. Historical monograph]. Kiev: $\mathrm{V}$ universitetskoi tipografii (I. I. Zavadskogo). [in Russian].

17. Ocherk istorii goroda Chernigova, 907-1907 [Essay of the history of the city of Chernigov, 9071907]: yubil. izd. Chernigov. Gor. Upravy, 1908. Chernigov: Tip. Gub. Zemstva. [in Russian].

18. Lazarevskii, A. M., 1888. Opisaniie staroi Malorossii. Vol. 1. Polk Starodubskii [Description of old Little Russia. Vol. 1. Starodubsky Regiment]. Kiev. [in Russian].

19. Lazarevskii, A. M., 1893. Opisaniie staroi Malorossii. Vol. 2. Polk Niezhynskii [Description of old Little Russia. Vol. 2. Niezhynsky Regiment]. Kiev. [in Russian].

20. Barvinskii, V., 1908. Do istorii zakriposchennia selian v Livobichnii Ukraini [To the history of fixing peasants in Left-Bank Ukraine]. Zapysky NTSh, 81(1), pp. 154-155. Miscellanea. [in Ukrainian].

21. Barvinskii, V., 1909. Materily do istorii suspil'nogo ta ekonomichnogo pobutu Livoberezhnji Ukrainy v XVIII [Materials to the history of social and economic life of Left-Bank Ukraine in the XVIII c.]. Zapysky NTSh, 90(4), pp. 154-155. [in Ukrainian].

Отримано: 03.12.2020 p. 


\title{
BLACK SEA COSSACK ARMY BETWEEN THE SOUTHERN BUG AND THE DNIESTER: HISTORIOGRAPHY OF THE ISSUE
}

\author{
Oleksandr Lozheshnyk \\ ORCID: https://orcid.org/0000-0002-4515-5511 \\ Post-graduate student of the Department of History of Ukraine \\ Odessa I.I. Mechnikov National University \\ 2, Dvoryanska Str., Odessa, 65082, Ukraine \\ sandro241298@ukr.net
}

The article analyzes the historiography of the Black Sea troops during their stay in the BugDniester interfluves, which objectively can be divided into three main periods, each of which is characterized by its own "vision" and interpretation of the history of the Black Sea troops. So, for example, if the first period is characterized by an ambiguous attitude to the Ukrainian Cossacks: the idealization changes to openly biased approaches, which completely deny any constructivism in their history; the third period is characterized by a burst of interest in the history of the Black Sea troops on the interfluve territory, the identification of new archival documents and rethinking of previously known facts. The diversity of research allows, by comparing information and comparing facts in the works of different authors, to objectively cover the history of the army during its stay in the Bugo-Dniester interfluves area.

By the beginning of the 20th century a certain tradition in the study of the history of the Black Sea troops was formed. Its main features were: the use of a narrow range of sources of official origin, absolutization of the role of the Russian Empire government in the history of the Black Sea troops. This is explained by the fact that a critical analysis of the government policy and activities of the local administration on the Cossacks was not possible for a number of objective reasons: the stay of this topic in the shadow of more topical historiographical problems, limited access to the source base.

After 1917 studies of the history of the Black Sea Cossacks were transferred to the level of local history studies and for ideological reasons almost never took place. The next stage in the studying of the history of the army is connected with the second half of the 20th century. Among the most striking works of this period are the studies of V. Golobutsky and A. Bachinsky.

Thanks to the use of archival materials, a significant part of which was first introduced into the scientific turnover A. Bachinsky enriched the factual basis of the history of the Black Sea Army Cossacks at that time, drawing attention to their relations with the Turkish Cossacks.

Thus, during the second half of the twentieth century, the scope of research on the history of the Black Sea Army during its settlement in the Bugo-Dniester interfluvial was significantly expanded, new sources were used to study the socio-economic aspects of the Cossacks' situation during that period.

So, investigating the stay of the Cossacks of the Black Sea troops on the territory of Bug-Dniester interfluves, historians passed a way from the scientific interest in the history of the south of Ukraine as a whole (in the first half of the XIX century) to the fundamental works on various aspects of social and economic history of irregular Cossack formation of the late XVIII century (at the end of the XX-at the beginning of the XXI century).

Key words: Historiography, Black sea Cossack army, the Southern Bug, the Dniester, settlement and economic development of the region. 
Олександр Ложешник ORCID: https://orcid.org/0000-0002-4515-5511

Аспірант кафедри історія України Одеського національного університету імені I.I. Мечникова Вул. Дворянська, 2, Одеса, 65082, Україна sandro241298@ukr.net

\section{ЧОРНОМОРСЬКЕ КОЗАЦЬКЕ ВІЙСЬКО В МЕЖИРІЧЧІ ПІВДЕННОГО БУГУ ТА ДНІСТРА: ІСТОРІОГРАФІЯ ПИТАННЯ}

В статті проаналізовано історіографію Чорноморського війська під час його перебування в Буго-Дністровському межиріччі. Головний наголос зроблено на висвітленні проблеми оселення та господарського освоєння краю. Виокремлено та синтезовано етапи розвитку, важливі напрямки історичних досліджень та їхні особливості, висвітлено стан сучасних історичних пошуків та вказано на їхні перспективи.

Ключові слова: історіографія, Чорноморське козаџьке військо, Буго-Дністровське межиріччя, оселення та господарське освоєння краю.

Останні десятиліття ознаменувалися значним піднесенням української історіографії у вивченні широкого кола проблем, присвячених історії Чорноморського війська під час його перебування в Буго-Дністровському межиріччі. Але, незважаючи на широке обговорення зазначених проблем на наукових конференціях та в пресі, на сторінках фахових часописів та збірників, перевидання вартісних праць попередників, підготовку й захист кандидатських дисертацій, появу цікавих монографій та узагальнюючих досліджень, все ще не вдалося комплексно систематизувати надбання вчених - істориків щодо Бузько-Дністровського періоду (1787-1791 рр.) Чорноморського війська.

Даний сумний факт пояснюється тим, що протягом багатьох років чимало істориків, досліджуючи козацтво, замовчували факти, які свідчили про перебування чорноморців на території Буго-Дністровського межиріччя. I це в той час, коли завдяки напрацюванням А. Скальковського цей регіон став своєрідним «першопрохідцем» у виокремленні наукового напрямку дослідження історії українського козацтва. До того ж саме в Одесі було вперше надруковано «Устное повествование бывшего запорожца Н. Л. Коржа», що й досі містить в собі неоціненні відомості із життя чорноморців, зокрема, ілюструючи їх перебування на території Хаджибею. Окрім того, починаючи з 1844 р. майже в кожному з 33 томів «Записок Одеського Імператорського товариства історії та старожитностей» друкувались матеріали та документи з історії українського козацтва.

Історіографію перебування козаків Чорноморського війська на території БугоДністровського межиріччя, заселення та економічного освоєння краю об'єктивно можна розділити на три основні періоди: перший період: XIX - початок XX ст., другий період: 1920-ті - 1990-ті рр., третій період: 1991 р. - початок XXI ст.

Кожен період характеризується своїм «баченням» та трактуванням історії Чорноморського війська. Так, наприклад, якщо для першого періоду властиве неоднозначне ставлення до українських козаків: ідеалізація змінюється відверто упередженими підходами, які повністю заперечують будь-який конструктивізм в їх історії; то для третього періоду властиві бурхливий сплеск інтересу до історії козаків Чорноморського війська на території межиріччя, виявлення нових архівних доку- 
ментів, переосмислення раніше відомих фактів. Різноплановість досліджень дає змогу, порівнюючи відомості та зіставляючи факти у працях різних авторів, об'єктивно висвітлювати історію війська під час його перебування в БугоДністровському межиріччі.

Початком вивчення історії Чорноморського війська в зазначений період стали праці А. Скальковського, який одним з перших почав займатися систематичним дослідженням історії Південної України загалом та Чорноморського війська в контексті вивчення Війська Запорозького. Проаналізувавши значну кількість документів Архіву Коша Війська Запорозького Низового та Канцелярії Новоросійського і Бессарабського генерал-губернатора, дослідник сформував своє бачення ролі козацтва в історії південноукраїнського регіону, яке відрізнялось від офіційної точки зору царського уряду, сформульованої в указі 1775 р. про знищення Запорозької Січі. А. Скальковський наголошував на тому, що «віднайдені запорозькі документи подають нам дипломатичне, церковне, військове, судове, торговельне, адміністративне і навіть приватне листування запорожців» [61, с. 4-5], що допомогло надати документальне підтвердження історії Чорноморського війська.

У дослідженні «Історія Нової Січі, або останнього Коша Запорозького» Аполлон Олександрович описав передумови створення та «зародження» Чорноморського війська, вказавши на перебування козаків на території сучасної Одещини, ще задовго до звільнення Очаківської області від турків в 1789 р.: «В Одесі збереглись перекази, що запорожці, які «зашуміли веслами до Тилігулу», там не всиділи, а оселились біля підніжжя Хаджибейської фортеці в так званій тепер Карантинній Балці» [60, с. 198].

Археографічні праці дослідника з історії козацтва не втрачають актуальності й сьогодні. Безперечною заслугою А. Скальковського є введення до наукового обігу нового фактологічного матеріалу щодо появи козаків у регіоні, їх оселення та господарського освоєння краю $[56$, с. $127 ; 58$, с. 276]; публікація документів, що стосувались Чорноморської козацької команди, зокрема переписів населення Одеси 1795 та 1797pp. [57, с. 45-46, 48-49, 61-62]. Деякі, хоча й досить уривчасті свідоцтва про Чорноморську команду містяться і в його статистичній праці «Хронологическое обозрение истории Новороссийского края» [59]. Але найбільша цінність напрацювань А. Скальковського в тому, що більшість оригіналів документів Коша Запорозького, які зберігалися в Державному архіві Одеської області, на жаль, в 1960-х рр. була втрачена.

Поряд із А. Скальковським працював з архівом Коша Яків Павлович Новицький. Протягом 1886-1898 рр. він вивчав джерела Архіву, що знайшло відображення в чисельних публікаціях. Для дослідження історії Чорноморського війська найцікавішими є дослідження «Описание границ и городов бывшей Азовской губернии, Левобережная часть нынешней Екатеринославской губернии 1775-1788 гг. Архивные источники» [41], що містить цінні відомості щодо заселення південного краю, дозволяє зрозуміти історичні передумови та пояснити соціально-економічні причини появи Чорноморського війська в останній чверті XVIII ст.; «История города Александровска Екатеринославской губернии в связи с историей возникновения крепостей Днепровской линии», де опубліковано список чорноморських козаків засновників Олександрівська. Заслуговують на увагу й додатки до розвідки, де вміщені документи різної видової належності 3 інформацією про перебування колишніх запорожців у складі Чорноморського війська [40, с. 50, 185, 210-263, 271-303].

У 1889-1910 рр. Я. Новицький опублікував різноманітні документи та замітки, що дозволяють простежити долі чорноморських козаків; дослідити родоводи козацької старшини та пояснити причини формування Чорноморського війська. 
Значення цих публікацій вкрай важливе, бо до сьогодні не дійшла більшість першоджерел, якими користувався дослідник. До того ж переважна частка оприлюднених Я.Новицьким документів була взята не 3 власних зібрань А. Скальковського чи інших дослідників, а з місцевих архівів.

Поряд 3 документальним матеріалом Я. Новицький у своїх розвідках використовував і усні джерела [40, с. 217, 322, 329]. Поєднання рукописного матеріалу з усними джерелами дозволило досліднику відтворити неповторні сторінки повсякденного життя чорноморців. Опрацьовані ним матеріали місцевих архівів та усні перекази старожилів, свідків пам'ятних подій стали канвою для написання низки історичних та статистичних праць. Поміж таких розвідок звертає на себе увагу праця «С берегов Днепра (Очерки Запорожья). Путевые записки и исследования», де Я. Новицький не тільки зафіксував розповіді 70-річного діда Миколи Білого - внука «війська Чорноморського полкового осавула» Федора Білого, а й навів витяги 3 документальних джерел, які зберігалися в родині Білих не одне покоління й були зафіксовані в справі про родовід Білих, що відклалася в Архіві предводителя дворянства Олександрійського повіту.

Доробок А. Скальковського став поштовхом у появі студій з розгляду історії Чорноморського війська в зазначений період. Починаючи 31883 р. козакознавчою тематикою займався Д. Яворницький. Протягом багатьох років дослідник мандрував теренами Катеринославської, Херсонської, Таврійської та Полтавської губерній, розшукуючи запорозькі (чорноморські) старожитності, записував від місцевих старожилів народні пісні, легенди, прислів'я про козацьку давнину. Згодом знайдені під час мандрівок та експедицій матеріали стали основою низки його краєзнавчих праць [71, 72]. Зокрема, в археографічній збірці «До історії Степової України» вчений опублікував документи, опрацьовані в архіві казенної палати Катеринослава, зосередивши увагу на заснуванні причорноморських міст i сіл у колишніх запорозьких вольностях.

Історико-краєзнавчі аспекти заявленої теми досліджували в ХІХ ст. О. Маркевич [37], В. Надлєр [38, 39], К. Смольянинов [61, 62], В. Бімбасов [3], розглядаючи розселення козаків Чорноморського війська в м. Одеса і його околицях та існування Чорноморської козацької команди. В цьому напрямкові проводили дослідження В. Яковлєв, вказавши «бывшие в ведении Черноморского войска селения»: Біляївку (Головківку), Калаглію, Кучургани, Глинне, Чобручі, Незавертай, Аджидер, Яськи, Ханкишл (Удобне), Рошу (Козацьке), Акерман, Коротне [73, 74]; О. Орлов, розповівши про долю чорноморців, що залишилися в Буго-Дністровському межиріччі після переселення основної частини війська на Кубань [23].

Окрім фактологічного матеріалу у своїх напрацюваннях історики використовували місцеві перекази, зазначаючи, що по селах та хуторах «Дальницької ділянки» «оселились залишки колись славного війська Запорозького». Цієї думки дотримувався й О. Де-Рібас, описуючи, як після розгрому Січі частина запорожців разом зі своїми родинами оселилась «де кому було дозволено, й багато з них опинилось під стінами Хаджибею» [15]. На жаль, цікаві подробиці життя чорноморців на околицях Хаджибею (Одеси) не мають фактологічних підтверджень [22, 63].

Оригінальними є дослідження П. Іванова, написані після експедиції по місцях, де мешкали нащадки козаків та опрацювання різнопланових архівних документів. Перебуваючи в 1901 p. у с. Слободзея, вчений ознайомився із матеріальними залишками перебування тут чорноморців та відвідав хату нащадка козаків, який відмовився переселитись на Кубань. У його працях вміщено подробиці, що 
стосуються господарства чорноморців та клопотів, пов'язаних 3 переселенням на Кубань [19, 20], опис предметів ритуального призначення і книжок, подарованих свого часу військовим суддею А. Головатим, купча на продаж А. Головатим свого хутору з будинком і млином 28 квітня 1793 р. купцеві С. Кленову [20, 21].

Продовжили дослідження процесів колонізації Півдня України та участі в господарському освоєнні краю козаків Чорноморського війська Д. Багалій [4] та В. Біднов $[6,7]$, подаючи цінний матеріал щодо специфіки заселення краю.

Окрему групу в історіографії зазначеної тематики становить «кубанська історіографічна школа», яку репрезентують кубанські науковці (переважно українського походження та вихідці з козацького середовища, що не могло не вплинути на загальні концепції їхніх досліджень) . У пошуках історичних витоків Чорноморського війська дослідниками було опрацьовано джерела ДАКК, що стосувались обставин виникнення іррегулярного формування та основних моментів його історії наприкінці XVIII ст., долі його окремих представників, насамперед кошових отаманів.

П. Короленко, використовуючи архівні документи ДАКК, описав процес трансформації решток колишнього запорозького суспільства у Чорноморське військо $[27,31,32,33]$ та написав біографії старшин - С. Білого, З. Чепіги й А. Головатого $[26,28,29,30]$. Щоправда, його праці вирізняються описовістю та фактографічністю у викладі матеріалу. Як представник офіційної дворянсько-монархічної ідеології, автор зображав козаків Чорноморського війська насамперед захисниками інтересів уряду Російської імперії.

Прорив у дослідженні Чорноморського війська здійснив Ф. Щербина [70], поклавши в основу досліджень архівні документи різної видової належності: актові, справочинні, статистичні. Поряд з ними, учений не останнє місце відводив мемуарним творам, у тому числі й епістолярії, в яких, на думку вченого, можна віднайти свідчення, які б характеризували побутові особливості козака, його світогляд.

Таким чином, до початку ХХ ст. утворилася певна традиція у дослідженні історії Чорноморського війська. Головними ії особливостями були: використання вузького кола джерел офіційного походження, абсолютизація ролі уряду Російської імперії в історії чорноморців. Це пояснюється тим, що критичний аналіз політики уряду та діяльності місцевої адміністрації щодо козаків був неможливим через низку об'єктивних причин: перебування зазначеної теми у тіні більш актуальних історіографічних проблем, обмеженість доступу до джерельної бази.

Після 1917 р. дослідження історії Чорноморського війська під час їх перебування в Буго-Дністровському межиріччі у зазначений період було переведено на рівень краєзнавчих досліджень та з ідеологічних причин майже не проводилося. Як виняток, слід назвати праці: Ф. Петруня [42, 43] (карта поселень Чорноморського війська, як і висновки вченого, на жаль, і досі залишаються неопублікованими); О. РябінінаСкляревського [44], написані на основі опрацювання архівних справ Державного архіву Одеської області; Є. Загоровського [16], який негативно оцінював факт переселення 3 Очаківської області чорноморців та вказував на те, що вони були нащадками запорожців, які примирилися 3 «новим порядком речей» після зруйнування Запорозької Січі.

Наступний етап вивчення історії війська пов'язаний з другою половиною ХХ ст. Серед найяскравіших праць цього періоду слід назвати дослідження В. Голобуцького $[8,9]$, що зосередив свою увагу головним чином на господарському устрої та соціально-економічних стосунках чорноморців, які розглядав через призму нескінченної класової боротьби в козацькій громаді. 
Велику увагу дослідженню соціально-економічних процесів Півдня України приділили у своїх працях В. Загоруйко [18] та В. Кабузан [24, 25]. Так, наприклад, В. Загоруйко назвав козацтво корінним населенням краю, а важливим доповненням до його книги стали примітки, що являють собою «словник» місцевої історії.

В 60-ті pp. ХX ст. історію Чорноморського війська (на основі матеріалів Державного архіву Одеської області та Державного архіву Краснодарського краю) почав досліджувати А. Бачинський. У співавторстві з О. Бачинською вченим була написана книга «Козацтво на Півдні України 1775-1869 рр.» [5], де на основі аналізу опублікованих та нововиявлених архівних документів усестороннє розглянуто основні моменти історії іррегулярного формування, особливості громадського та господарського життя козаків, пов'язані з Буго-Дністровським межиріччям.

Завдяки використанню архівних матеріалів, значна частина яких була вперше введена у науковий обіг, як і «Іменний список чорноморських старшин та козаків, які залишаються при місті Одесі» (1797р.), А. Бачинський збагатив фактологічну базу історії козаків Чорноморського війська в зазначений час, звернувши увагу на їх зв'язки з турецькими запорожцями.

Низку архівних документів, що дозволили скласти перепис населення Одеси 1799 р. та виокремити біля 300 родин чорноморців, які залишились після переселення на Кубань, використала в своїх дослідженнях О. Дружиніна, окресливши специфіку розвитку регіону та розкривши залежність колонізаційних процесів від особливостей господарського розвитку.

Таким чином, протягом другої половини XX ст. було значно розширено рамки досліджень 3 історії Чорноморського війська під час його поселення в БугоДністровському межиріччі, залучено нові джерела для дослідження соціальноекономічних аспектів становища козаків в зазначений період.

Наприкінці 1980 - на початку 1990 рр. поширюється загальногромадський інтерес до історії козацького руху в Україні. Значним чином це пояснюється тим, що в незалежній державі, у зв'язку зі зняттям цензурних політико-ідеологічних обмежень, почався процес переосмислення української історіографії, для якої, як i наприкінці минулого століття, козацтво залишалося уособленням славних сторінок вітчизняної історії. Так як Чорноморське військо вважається спадкоємцем та правонаступником Запорозької Січі в південноукраїнському регіоні, почалося відродження вивчення його історії на теренах південної України.

Серед цікавих напрацювань цього періоду слід назвати дослідження І. Анцупова $[1,2]$ та Р. Шияна [64, 65]. Зокрема, I. Анцупов детально розкрив загальні процеси колонізації Буго-Дністровського межиріччя козаками Чорноморського війська та історію формування аграрних відносин на Півдні України. Значна кількість архівних матеріалів дозволила автору грунтовно охарактеризувати картину соціального та економічного розвитку досліджуваної території.

Наприкінці XX ст. поновилися дослідження козацьких намогильних пам'ятників, завдяки яким збережено дослівні написи на хрестах козацьких поховань, зафіксовано їх точне місцезнаходження. Вивчаючи намогильні пам'ятники на околицях Одеси та в прилеглих селах (Куяльник, Усатове, Нерубайське тощо), Р. Шувалов навів цікаві факти про життя чорноморців в Буго-Дністровському межиріччі [66, 67, 68, 69]. На основі історичних матеріалів, серед яких були записи метричних книг місцевої Вознесенської церкви за 1809-1822 рр. та польових даних він довів факт проживання козаків Чорноморського війська на схилах Шкодової і Жевахової гір та їх поховання на Куяльницькому козацькому кладовищі. 
До вивчення намогильних козацьких пам'ятників з 1994 р. долучився I. Сапожніков [34, 49, 51, 53]. Слід зазначити, що окрім вивчення козацьких хрестів [46, 51], вчений плідно працює 3 матеріалами Держархів Одеської області, які висвітлюють історію Чорноморського війська під час його перебування на території Хаджибею (Одеси). На їх основі була написана низка праць [47, 50], серед яких вирізняються студії «Запорожские и черноморские казаки в Хаджибее и Одессе (1770-1820-е гг.)» [48] (спільно з Г. Сапожніковою), де розглянуто роль полкового осавула Ф. Черненка при оселенні козаків в околицях Хаджибею, після переселення чорноморців на Кубань в 1792-1793 рр.

Поряд із зазначеними працями 3 друку вийшли і продовжують виходити дослідження, які стосуються поставленої наукової проблеми. Серед них праці Т. Гончарука $[10,11,12,13,14]$ та С. Гуцалюка, I. Сапожнікова та Г. Сапожнікової $[45,48,52,54]$, А. Ложешник $[35,36]$, що торкаються низки козакознавчих питань щодо життя та діяльності чорноморців в зазначений період в Буго-Дністровському межиріччі.

Отже, досліджуючи перебування козаків Чорноморського війська на території Буго-Дністровського межиріччя, історики пройшли шлях від наукового інтересу до історії півдня України в цілому (в першій половині ХІХ ст.), до грунтовних праць щодо різних аспектів соціально-економічної історії іррегулярного козацького формування кінця XVIII ст. (наприкінці XX - на початку XXI ст.). Щодо характеру сучасних досліджень історії Чорноморського війська, то слід відзначити їх спрямування на «занурення» вглиб теми шляхом пошуку нових джерельних баз i постановки та розробки нових аспектів. Оприлюднення нових архівних документів та «перепрочитання» раніше опублікованих дає змогу широкому загалу розглянути різні аспекти історії чорноморців в Буго-Дністровському межиріччі.

\section{Джерела та література:}

1. Анцупов И. А. Казаки и военные поселенцы на Днестре и Буге XVIII-XIX веков / И. А. Анцупов // Ежегодный исторический альманах Приднестровья. - 1997. - № 1. - С. 3039.

2. Анцупов И. А. Казачество российское между Бугом и Дунаем. / И. А. Анцупов. Кишинев, 2000. - 290 с.

3. Архив графов Мордвиновых: в 10 т. / предисл. и прим. В. А. Бимбасова. - СПб.: Тип. И. Н. Скороходова, 1901. - Т. 1. - 713 с.

4. Багалей Д. И. Колонизация Новороссийского края и первые шаги его по пути культуры / Д. И. Багалей // Киевская старина, 1889. - Т. 41. - С. 351-360.

5. Бачинський А. Д. Козацтво на Півдні України 1775-1869 pp. / А. Д. Бачинський, О. А. Бачинська. - Одеса: Маяк, 1995. - 56 с.

6. Беднов В. А. К истории бывших запорожских старшин и казаков./ В. А. Беднов. Екатеринослав: Тип. губ. земства, 1915. - 47 с.

7. Беднов В. Материалы для истории колонизации бывших запорожских владений. / В. Беднов. - Екатеринославль: тип. Губернского земства, 1914. -48 с.

8. Голобуцкий В. А. Черноморское казачество./ В. А. Голобуцкий. - Киев: Академия наук УССР, 1956. - $416 \mathrm{c}$.

9. Голобуцький В. О. Чорноморське козацтво за Бугом: до питання про соціальноекономічний розвиток степової України наприкінці XVIII ст. / В. О. Голобуцький // Наукові Записки Інституту історії АН УРСР. -Київ, 1952. - Т. 4. - С. 133-154.

10. Гончарук Т. Г. Григорій Потьомкін - гетьман українського козацтва: наук.-популяр. нарис. / Т. Г. Гончарук. - Одеса : Астропринт, 2002. - 141 с. 
11. Гончарук Т. Г. История Хаджибея (Одессы). 1415-1795 гг. Одесса: Астропринт, 1997. $88 \mathrm{c}$.

12. Гончарук Т. Г. Історія Хаджибея (Одеси) 1415-1795 pp. в документах. / Т. Г. Гончарук. Одеса: Астропринт, 2000. - 372 с.

13. Гончарук Т. Г. Нащадки українських козаків та «народження Одеси». / Т. Г. Гончарук. Одеса: Астропринт, 2006. - 144 с.

14. Гончарук Т. Г. Українське козацтво та Хаджибей (Одеса). Середина XVI ст. 1794 р.: популярний нарис та додані документи з друкованих джерел./ Т. Г. Гончарук, С. Гуцалюк. -. Одеса, 1998. - 67 с.

15. Де-Рибас А. Старая Одесса: исторические очерки и воспоминания. / А. Де-Рибас. Одесса: Тип Южнорус. о-ва печати, 1913. - 51 с.

16. Загоровский Е. А. Деятельность П. А. Зубова по управлению степной Украиной / Е. А. Загоровский // Вісник Одеської комісії краєзнавства. - 1929. - № 4-5. - С. 44-58.

17. Загоровский Е. А. Матеріали до історії адміністративного устрою південної України: (друга половина XVIII - перша половина XIX століття)./ / Е. А. Загоровский. - 1999. C.492-506.

18. Загоруйко В. А. По страницам истории Одессы и Одесщины: историографический и библиографический обзор./ В. А. Загоруйко. - Одесса, 1957. - Вып. 1. - 155 с.

19. Иванов П. А. Материалы по истории Запорожья в XVIII в. / П. А. Иванов // ЗООИД. Одесса,1897. - Т. 20. - С. 59-100.

20. Иванов П. А. Черноморские казаки в Слободзее / П. А.Иванов // ЗООИД. - 1902. - Т. 24. - С. 80-91.

21. Иванов П. К истории запорожских казаков после уничтожения Сечи / П. А.Иванов // ЗООИД. - 1904. - T. 25. - С. 20-40.

22. Из прошлого Одессы : сб. ст. / сост. Л. М. Де-Рибас. - Одесса: изд. Г. Г. Маразли, 1894. $413 \mathrm{c}$.

23. Исторический очерк Одессы с 1794 по 1803 год / сост. А. Орлов. - Одесса: тип. Шульце, 1885. $-144 \mathrm{c}$.

24. Кабузан В. М. Заселение Новороссии (Екатеринославская и Херсонская губернии) в XVIII первой половине XIX в. (1719-1858 гг.) / В. М. Кабузан; отв. ред. Л. Г. Бескровный. - М.: Наука, 1976. - 306 c.

25. Кабузан В. М. Народонаселение Бессарабской области и Левобережных районов Приднестровья, конец XVIII - первая половина XIX в. / В. М. Кабузан . - Кишинев: Штиинца, 1974. - 157 c.

26. Короленко П. П. Головатый - кошевой атаман Черноморского казачьего войска. /

П. П. Короленко. - Екатеринодар: Тип. Кубан. обл. правл., 1904. - 201 с.

27. Короленко П. П. Двухсотлетие Кубанского казачьего войска: ист. очерк. / П. П. Короленко. Екатеринодар: Тип. Кубанского обл. правления, 1896. - 96 с.

28. Короленко П. П. Кошевые атаманы Черноморского казачьего войска XVIII ст.: историкобиографический очерк. / П. П. Короленко. - СПб.: Вестник казачьих войск, 1896. - 48 с.

29. Короленко П. П. Первые четыре атамана бывшего Черноморского (ныне Кубанского) казачьего войска. / П. П. Короленко. - Екатеринодар, 1892. - 36 с.

30.Короленко П. П. Письмо Н. Т. Белого к П. П. Короленко о Сидоре Белом / П. П. Короленко. // ЗООИД.-1898. - Т. 21. - С. 46-56.

31. Короленко П. П. Предки кубанских казаков на Днепре и на Днестре. / П. П. Короленко. Екатеринодар: Тип. П. Ф. Бойко, 1900. -203 с.

32. Короленко П. П. Черноморское казачье войско (1775 - 1792): ист. очерк. / П. П. Короленко. Екатеринодар: Типо-литогр. А. В. Сташевского, 1892. - 64 с.

33. Короленко П. П. Черноморцы. / П. П. Короленко. - СПб.: Тип. Департамента уделов, 1874. $272 \mathrm{c}$. 
34. Кушнір В. Г. Попередні підсумки досліджень кам'яних хрестів Одещини / В. Г. Кушнір, I. В. Сапожников // Українська національна ідея: минуле, сучасне, майбутнє: матеріали міжнародної конференції. - Одеса. 1995. - С. 120-121.

35. Ложешник А. С. Старшина козацьких військ на Півдні України (кінець XVIII - перша половина XIX ст.): просопографічний портрет: дис ... канд. іст. наук. / А. С. Ложешник- Одеса, 2017. $-239 \mathrm{c}$.

36. Ложешник А. Формулярні списки старшини Чорноморського козацького війська за 1804 р., як історичне джерело / А. Ложешник // Чорноморська минувшина. - Одеса: СПД -ФО Бровкін О. В., 2013. - Вип. 8. - С. 174-188.

37. Маркевич А. И. Документы, относящиеся к истории города Одессы / А. И. Маркевич // ЗООИД. - 1893. - Т. 16. - С. 55-116

38. Надлер В. К. К изучению истории г. / В. К. Надлер. - Одессы. - Одесса, 1893. - 11 с.

39. Надлер В. К. Одесса в первые эпохи ее существования. / В. К. Надлер. - Одесса: Тип. В. В. Кирхнера, 1893. - 100 с.

40. Новицкий Я. Твори в 5-ти томах. Т. 1: История города Александровска Екатеринославской губернии в связи с историей возникновения крепостей Днепровской линии. 1770 - 1806 гг. / Я. Новицкий. - Запоріжжя: ПП «АА Тандем», 2007. - 508 с.

41. Новицкий Я. П. Описание границ и городов бывшей Азовской губернии (Левобережная часть нынешней Екатеринославской губернии) (1775- 1783 гг.). / Я. Новицкий. - Александровск, 1910. $-38 \mathrm{c}$.

42. Петрунь Ф. Е. Первые русские карты окрестностей нынешней Одессы и их физикогеографическое содержание / Ф. Е. Петрунь // Тр. Одес. гос. ун-та. - 1955. - Т. 145, вып. 3: Геол. и географ. науки. - С. 141-149.

43. Петрунь Ф. Е. Пути и подступы к Днестру: очерки по истории русской географии 2-й половины XVIII ст.: автореф. дис. ... канд. географ. наук. / Ф. Е. Петрунь . - Байрам-Али, 1944. $283 \mathrm{c}$.

44. Рябінін-Скляревський О. О. 3 життя Задунайської Січі / О. О. Рябінін-Скляревський // Україна. -1929. - Т. 34. - С. 7-34.

45. Сапожников И. В. Каменные кресты предместий Одессы: конец XVIII - XIX вв. / И. В. Сапожников. - Ильичевск: Элтон-2: Гратек, 1999. - 98 с.

46. Сапожников И. В. Намогильные памятники населения степей Нижнего Приднестровья (конец XVIII - первая половина XIX вв.). / И. В. Сапожников. - Одесса: Черноморье, 1997. - 134 с.

47. Сапожников И. В. Описание Одессы и Северного Причерноморья 1780-х годов: к 210-й годовщине штурма Хаджибейского замка. / И. В. Сапожников. - Ильичевск: Элтон-2 - Гратек, 1999. - $80 \mathrm{c}$.

48. Сапожников И. В. Запорожские и черноморские казаки в Хаджибее и Одессе (1770-1820-е гг.). / И. В.Сапожников, Г. В. Сапожникова. - Одесса: ОКФА, 1998. - 273 с.

49. Сапожников И. В. Основные итоги исследования православного кладбища Аккермана / И. В. Сапожников, Ю. А. Слюсарь // Древнее Причерноморье. - Одесса, 1996. - С. 97-100.

50. Сапожников I. В. Запорозькі та чорноморські козаки в Хаджибеї та Одесі / I. В. Сапожников // Київська. старовина. - Київ, 1998. - №3. - С. 11-25.

51. Сапожников I. В. Кам'яні хрести Степової України (XVIII - перша половина XIX ст.). / I. В. Сапожников. - Одеса: Чорномор'я, 1997. - 165 с.

52. Сапожников I. Чорноморська козацька команда в Хаджибеї та Одесі (1794-1797 роки) / І.Сапожников, Г. Сапожникова // Хаджибей-Одеса та українське козацтво (1415-1797 роки). Одеса: ОКФА, 1999. - С. 237-290.

53. Сапожников I. Типологія кам'яних намогильних хрестів Південно-Західної України / І. Сапожников, Ю. Слюсар, Р. Шувалов // Старожитності Причорномор'я. - Одеса. 1995. - Вип. 2. - C. $16-47$.

54. Сапожніков I. В. Штурм острова Березань чорноморськими козаками. / I. В. Сапожніков. Київ; Іллічівськ: Елтон 2; Гротек, 2000. - 128 с. 
55. Сапожніков I. В. Кам'яні хрести Одещини (з матеріалів розвідок) / І. В. Сапожніков, В. Г. Кушнір, А. С. Островерхов // Старожитності Причорномор'я. -Одеса, 1995. - Вип. 2. - С. 48-63.

56. Скальковский А. А. Опыт статистического описания Новороссийского края и Бессарабии. / А. А. Скальковский. - Одесса : Тип. Л. Нитче, 1850. - 386 с.

57.Скальковский А. А. Первое тридцатилетие истории города Одессы, 1793-1823. / А. А. Скальковский. - Одесса: Гор. тип., 1837. -296 с.

58. Скальковский А. А. Сравнительный взгляд на Очаковскую область в 1790 и 1840 гг. / А. А. Скальковский // ЗООИД. - Одесса, 1844. - Т. 1. - С. 257-277.

59. Скальковский А. А. Хронологическое обозрение истории Новороссийского края. / А. А. Скальковский. - Одесса: Гор. тип., 1838. - Ч. 2. - 349 с.

60. Скальковський А. О. Історія Нової Січі, або останнього Коша Запорозького. / А. О. Скальковський. - Дніпропетровськ: Січ, 1994. - 678 с.

61. Смольянинов К. История г. Одессы./ К. Смольянинов. - Одесса: Гор. Тип., 1853. - 284 с.

62. Смольянинов К. История Одессы . / К. Смольянинов // ЗООИД. - 1852. - Т. 3. - С. 338-432.

63. Старая Одесса: Взятие Хаджибея, основание Одессы, первый крестный ход 22 августа 1849 г. // Одесский листок. - 1909. - 22 августа

64.Шиян Р. I. Козацтво Південної України останньої чверті XVIII століття. / Р. I. Шиян. - Запоріжжя: Тандем-У, 1998. - 98 с.

65. Шиян Р. I. Чорноморське військо вірних козаків в останній чверті XVIII ст. / Р. I. Шиян. Запоріжжя: Тандем-У, 1996. - 28 с.

66. Шувалов Р. А. Казацкий Кош в окрестностях Одессы / Р. А. Шувалов // Археологічні дослідження пам'яток українського козацтва. - Київ, 1993. - Вип. 2. - С. 104-109.

67. Шувалов Р. А. Про що розповів некрополь (Куяльницьке козацьке кладовище міста Одеси). / Р. А. Шувалов. - Київ, 1992. - 125 с.

68. Шувалов Р. А. Украинские поселения в окрестностях Одессы / Р. А. Шувалов // Історичне краєзнавство Одещини. - Одеса, 1993. - Вип. 4. - С. 41-45.

69. Шувалов Р. Козацьке кладовище / Р. Шувалов // Пам’ятки України. - Київ, 1993. - №1/6. C. $180-181$.

70. Щербина Ф. А. История Кубанского казачьего войска. / Ф. А. Щербина. - Екатеринодар: Тип. Кубанского Областного Правления, 1910. - 746 с.

71.Яворницький Д. І. До історії степової України./ Д. І. Яворницький. - Дніпропетровськ: Січ, 2004. $443 \mathrm{c}$.

72. Яворницький Д. І. Запоріжжя в залишках старовини і переказах народу./ Д. І. Яворницький. Київ: Веселка, 1995. - 300 с.

73. Яковлев В. А. К истории заселения Хаджибея (1789 - 1795 гг.)./ В. А Яковлев. - Одесса, 1889. $-56 \mathrm{c}$.

74. Яковлев В. Из Одесской старины. Раздача земель в Гаджибее и его окрестностях. 1792-1794 /

В. Яковлев // Одесский вестник. - 1889. - 21 августа.

\section{References:}

1. Antsupov, I. A., 1997. Kazaki i voennye poselentsy na Dnestre i Buge XVIII-XIX vekov. Yezhegodnyy istoricheskiy almanakh Pridnestrovya, Vyp. 1, s. 30-39. [in Russian]

2. Antsupov, I. A., 2000. Kazachestvo rossiyskoe mezhdu Bugom i Dunaem. Kishinev. [in Russian].

3. Arkhiv grafov Mordvinovykh, 1901. Vol. 1. Sankt-Peterburg. [in Russian].

4. Bagaley, D. I., 1889. Kolonizatsiya Novorossiyskogo kraya i pervye shagi ego po puti kultury. Kievskaya starina, Vol. 41, s. 351-360. [in Russian].

5. Bachinskiy, A. D. \& Bachinska, O. A., 1995. Kozatstvo na Pivdni Ukrä̈ni 1775-1869 rr.. Odesa. [in Ukrainian].

6. Bednov,V. A., 1915. K istorii byvshikh zaporozhskikh starshin i kazakov. Yekaterinoslav. [in Russian].

7. Bednov, V., 1914. Materialy dlya istorii kolonizatsii byvshikh zaporozhskikh vladeniy.

Yekaterinoslavl. [in Russian].

8. Golobutskiy, V. A., 1956. Chernomorskoe kazachestvo. Kiev. [in Ukrainian]. 
9. Holobutskyi, V. O., 1952. Chornomorske kozatstvo za Buhom: do pytannia pro sotsialnoekonomichnyi rozvytok stepovoi Ukrainy naprykintsi XVIII st. Naukovi Zapysky Instytutu istorii AN URSR, Vol. 4, pp. 133-154. [in Ukrainian].

10. Honcharuk, T. H., 2002. Hryhorii Potomkin - hetman ukrainskoho kozatstva. Odesa. [in Ukrainian].

11. Goncharuk, T. G., 1997. Istoriya Khadzhibeya (Odessy). 1415-1795 gg. Odessa. [in Ukrainian].

12. Honcharuk, T. H., 2000. Istoriia Khadzhybeia (Odesy) 1415-1795 rr. v dokumentakh. Odesa. [in Ukrainian].

13. Honcharuk, T. H., 2006. Nashchadky ukrainskykh kozakiv ta «narodzhennia Odesy». Odesa. [in Ukrainian].

14. Honcharuk, T. H. \& Hutsaliuk, S., 1998. Ukrainske kozatstvo ta Khadzhybei (Odesa). Seredyna XVI st. - 1794 r.: populiarnyi narys ta dodani dokumenty z drukovanykh dzherel. Odesa. [in Ukrainian].

15. De-Ribas, A., 1913. Staraya Odessa: istoricheskie ocherki $i$ vospominaniya. Odessa. [in Russian].

16. Zagorovskiy, Ye. A., 1929. Deyatelnost P. A. Zubova po upravleniyu stepnoy Ukrainoy. Visnik Odeskoï komisii kraieznavstva,4-5, s. 44-58. [in Ukrainian].

17. Zahorovskyi, E. A., 1999. Materialy do istorii administratyvnoho ustroiu pivdennoi Ukrainy: (druha polovyna XVIII - persha polovyna XIX stolittia), s. 492-506. [in Ukrainian].

18. Zagoruyko, V. A., 1957. Po stranitsam istorii Odessy $i$ Odesshchiny: istoriograficheskiy $i$ bibliograficheskiy obzor, Vol. 1. Odessa.[in Ukrainian].

19. Ivanov, P. A., 1897. Materialy po istorii Zaporozhya v XVIII v. ZOOID, 20, pp. 59-100. [in Russian].

20. Ivanov, P. A., 1902. Chernomorskie kazaki v Slobodzee. ZOOID, 24, pp. 80-91. [in Russian].

21. Ivanov, P., 1904. K istorii zaporozhskikh kazakov posle unichtozheniya Sechi. ZOOID, 25, pp. 20-40. [in Russian].

22. Iz proshlogo Odessy, 1894. Odessa. [in Russian].

23. Istoricheskiy ocherk Odessy s 1794 po 1803 god, 1885. Odessa. [in Russian].

24. Kabuzan, V. M., 1976. Zaselenie Novorossii (Yekaterinoslavskaya i Khersonskaya gubernii) $v$ XVIII - pervoy polovine XIX v. (1719-1858 gg.). Mykolaiv. [in Ukrainian].

25. Kabuzan, V. M., 1974. Narodonaselenie Bessarabskoy oblasti $i$ levoberezhnykh rayonov Pridnestrovya, konets XVIII - pervaya polovina XIX v. Kishinev. [in Russian].

26. Korolenko, P. P., 1904. Golovatyy - koshevoy ataman Chernomorskogo kazachego voyska. Yekaterinodar. [in Russian].

27. Korolenko, P. P., 1896. Dvukhsotletie Kubanskogo kazachego voyska. Yekaterinodar. [in Russian].

28. Korolenko, P. P., 1896. Koshevye atamany Chernomorskogo kazachego voyska XVIII st.: istoriko-biograficheskiy ocherk. Sankt-Peterburg. [in Russian].

29. Korolenko, P. P., 1892. Pervye chetyre atamana byvshego Chernomorskogo (nyne Kubanskogo) kazachego voyska. Yekaterinodar. [in Russian].

30. Korolenko, P. P., 1898. Pismo N. T. Belogo k P. P. Korolenko o Sidore Belom. ZOOID, 21, pp. 46-56. [in Russian].

31. Korolenko, P. P., 1900. Predki kubanskikh kazakov na Dnepre i na Dnestre. Yekaterinodar. [in Russian].

32. Korolenko, P. P., 1892. Chernomorskoe kazache voysko (1775-1792). Yekaterinodar. [in Russian].

33. Korolenko, P. P., 1874. Chernomortsy. Sankt-Peterburg. [in Russian].

34. Kushnir, V. H. \& Sapozhnykov, I. V., 1995. Poperedni pidsumky doslidzhen kam'ianykh khrestiv Odeshchyny. Ukrainska natsionalna ideia: mynule, suchasne, maibutnie: materialy mizhnarodnoi konferentsii. Odesa. S. 120-121. [in Ukrainian].

35. Lozheshnyk, A. S., 2017. Starshyna kozatskykh viisk na Pivdni Ukrainy (kinets XVIII - persha polovyna XIX st.): prosopohrafichnyi portret. Odesa. [in Ukrainian].

36. Lozheshnyk, A., 2013. Formuliarni spysky starshyny Chornomorskoho kozatskoho viiska za 1804 r., yak istorychne dzherelo. Chornomorska mynuvshyna, 8, pp. 174-188. [in Ukrainian].

37. Markevich, A. I., 1893. Dokumenty, otnosyashchiesya k istorii goroda Odessy. ZOOID, 16, pp. 55-116. [in Russian]. 
38. Nadler, V. K., 1893. K izucheniyu istorii g. Odessy. Odessa. [in Russian].

39. Nadler, V. K., 1893. Odessa v pervye epokhi ee sushchestvovaniya. Odessa. [in Russian].

40. Novitskiy, Ya., 2007. Istoriya goroda Aleksandrovska Yekaterinoslavskoy gubernii v svyazi s istoriey vozniknoveniya krepostey Dneprovskoy linii. 1770 - 1806 gg. Vol. 1. Zaporizhzhya. [in Ukrainian].

41. Novitskiy, Ya. P., 1910. Opisanie granits $i$ gorodov byvshey Azovskoy gubernii (Levoberezhnaya chast nyneshney Yekaterinoslavskoy gubernii) (1775- 1783 gg.). Aleksandrovsk. [in Russian].

42. Petrun, F. Ye., 1955. Pervye russkie karty okrestnostey nyneshney Odessy i ikh fizikogeograficheskoe soderzhanie. Trudy Odesskogo gosudarstvennogo universiteta, 145 (3), pp. 141149. [in Ukrainian].

43. Petrun, F. Ye., 1944. Puti i podstupy k Dnestru: ocherki po istorii russkoy geografii 2-y poloviny XVIII st. Bayram-Ali. [in Russian].

44. Riabinin-Skliarevskyi, O. O., 1929. Z zhyttia Zadunaiskoi Sichi. Ukraina, 34, pp. 7-34. [in Ukrainian].

45. Sapozhnikov, I. V., 1999. Kamennye kresty predmestiy Odessy: konets XVIII - XIX vv. Ilichevsk. [in Ukrainian].

46. Sapozhnikov, I. V., 1997. Namogilnye pamyatniki naseleniya stepey Nizhnego Pridnestrovya (konets XVIII - pervaya polovina XIX vv.). Odessa. [in Ukrainian].

47. Sapozhnikov, I. V., 1999. Opisanie Odessy i Severnogo Prichernomorya 1780-kh godov: $k$ 210y godovshchine shturma Khadzhibeyskogo zamka. Ilichevsk. [in Ukrainian].

48. Sapozhnikov, I. V. \& Sapozhnikova, G. V., 1998. Zaporozhskie i chernomorskie kazaki $v$ Khadzhibee i Odesse (1770-1820-e gg.). Odessa. [in Ukrainian].

49. Sapozhnikov, I. V. \& Slyusar, Yu. A., 1996. Osnovnye itogi issledovaniya pravoslavnogo kladbishcha Akkermana. Drevnee Prichernomore, pp. 97-100. [in Ukrainian].

50. Sapozhnykov, I. V., 1998. Zaporozki ta chornomorski kozaky v Khadzhybei ta Odesi. Kyivska starovyna, 3, pp. 11-25. [in Ukrainian].

51. Sapozhnykov, I. V., 1997. Kamiani khresty Stepovoi Ukrainy (XVIII - persha polovyna XIX st.). Odesa. [in Ukrainian].

52. Sapozhnykov, I. \& Sapozhnykova, H., 1999. Chornomorska kozatska komanda v Khadzhybei ta Odesi (1794-1797 roky). Khadzhybei-Odesa ta ukrainske kozatstvo (1415-1797 roky), pp. 237-290. [in Ukrainian].

53. Sapozhnykov, I., Sliusar, Yu. \& Shuvalov, R., 1995. Typolohiia kamianykh namohylnykh khrestiv Pivdenno-Zakhidnoi Ukrainy. Starozhytnosti Prychornomoria, 2, pp. 16-47. [in Ukrainian].

54. Sapozhnikov, I. V., 2000. Shturm ostrova Berezan chornomorskymy kozakamy. Kyiv-Illichivsk. [in Ukrainian].

55. Sapozhnikov, I. V., Kushnir, V. H. \& Ostroverkhov A. S., 1995. Kamiani khresty Odeshchyny (z materialiv rozvidok). Starozhytnosti Prychornomoria, 2, pp. 48-63. [in Ukrainian].

56. Skalkovskiy, A. A., 1850. Opyt statisticheskogo opisaniya Novorossiyskogo kraya i Bessarabii. Odessa. [in Russian].

57. Skalkovskiy, A. A., 1837. Pervoe tridtsatiletie istorii goroda Odessy, 1793-1823. Odessa. [in Russian].

58. Skalkovskiy, A. A., 1844. Sravnitelnyy vzglyad na Ochakovskuyu oblast v 1790 i 1840 gg. ZOOID, 1, pp. 257-277. [in Russian].

59.Skalkovskiy, A. A., 1838. Khronologicheskoe obozrenie istorii Novorossiyskogo kraya. Ch. 2. Odessa. [in Russian].

60. Skalkovskyi, A. O., 1994. Istoriia Novoi Sichi, abo ostannoho Kosha Zaporozkoho. Dnipropetrovsk. [in Ukrainian].

61. Smolyaninov, K., 1853. Istoriya g. Odessy. Odessa. [in Russian].

62. Smolyaninov, K., 1852. Istoriya Odessy. ZOOID, 3, pp. 338-432. [in Russian].

63. Staraya Odessa: Vzyatie Khadzhibeya, osnovanie Odessy, pervyy krestnyy khod 22 avgusta 1849 g., 1909. Odesskiy listok, 22 avgusta. [in Russian]. 
64. Shyian, R. I., 1998. Kozatstvo Pivdennoi Ukrainy ostannoi chverti XVIII stolittia. Zaporizhzhia. [in Ukrainian].

65. Shyian, R. I., 1996. Chornomorske viisko virnykh kozakiv v ostannii chverti XVIII st. Zaporizhzhia. [in Ukrainian].

66. Shuvalov, R. A., 1993. Kazatskyi Kosh v okrestnostiakh Odessy. Arkheolohichni doslidzhennia pam'iatok ukrainskoho kozatstva, 2, pp. 104-109. [in Ukrainian].

67. Shuvalov, R. A., 1992. Pro shcho rozpoviv nekropol (Kuialnytske kozatske kladovyshche mista Odesy). Kyiv. [in Ukrainian].

68. Shuvalov, R. A., 1993. Ukraynskye poselenyia v okrestnostiakh Odessy. Istorychne kraieznavstvo Odeshchyny, 4, pp. 41-45. [in Ukrainian].

69. Shuvalov, R., 1993. Kozatske kladovyshche. Pam'iatky Ukrainy, 1/6, pp. 180-181. [in Ukrainian].

70. Shcherbina, F. A., 1910. Istoriya Kubanskogo kazachego voyska. Yekaterinodar. [in Russian].

71. Yavornytskyi, D. I., 2004. Do istorii stepovoi Ukrainy. Dnipropetrovsk. [in Ukrainian].

72. Yavornytskyi, D. I., 1995. Zaporizhzhia $v$ zalyshkakh starovyny i perekazakh narodu. Kyiv. [in Ukrainian].

73. Yakovlev, V. A., 1889. K istorii zaseleniya Khadzhibeya (1789-1795 gg.). Odessa. [in Russian].

74. Yakovlev, V., 1889. Iz Odesskoy stariny. Razdacha zemel v Gadzhibee i ego okrestnostyakh. 1792-1794. Odesskiy vestnik, 21 avgusta. [in Russian].

Отримано: 04.12.2020 p. 
ПУБЛІКАЦІЯ ДОКУМЕНТІВ

ISSN 2519-2523 (print)

DOI: $10.18524 / 2519-2523.2020 .15 .218685$

УДК 94(477.74):34 “1828-1868”

\title{
CRIMES, PUNISHMENT AND THEIR EXECUTION IN THE VILLAGES OF THE DANUBE (NOVOROSIYSKY) COSSACK ARMY (1828-1868)
}

\author{
Olena Bachynska \\ ORCID: https://orcid.org/0000-0003-0496-5742 \\ DSc (History), Professor \\ Odessa I.I. Mechnikov National University \\ 2, Dvoryanska Str., Odessa, 65082, Ukraine \\ Olena_an@ukr.net
}

The question of the system of punishments, their adequacy to the crimes committed has become important today. Discussion of this issue is important not only for Ukraine but also for most countries of the world. This changes the view of both the crimes themselves and their assessment. The institution responsible for the execution of sentences imposed under the legislation currently being modernized in Ukraine is called the penitentiary service. Its operation and effectiveness often depend not only on global rules, codes and practices, but also on local traditions in the penitentiary system and their enforcement. Certain crimes of a moral and ethical nature are difficult to assess in terms of legal norms, and at different times may not be considered as crimes. The study of these traditions actualizes the historical experience that needs to be studied, in particular on the territory of Ukraine, in such organizations as Cossack societies and Cossack troops. These were paramilitary structures that have clearly defined rights, responsibilities, a system of punishment and their execution. However, even in these structures there were deviations from national rules. In this regard, the objectives of our publication is to show, on the example of one archival case, the causes of crimes, their nature and form, the figures of prosecuted Cossacks, punishments and their implementation that existed in real life of the Cossacks, one of the last Cossacks formations of the XIX century on the territory of modern Ukraine - the Danube (Novorossiysk) army.

It was ascertained that the organization that considered the violations and served as a court in the Danube Cossack Army was a commission of the Military Court. It was determined that the main reasons for the lawsuits were the Cossacks' protests against the arbitrariness and abuse of officers and military officials, which manifested themselves in runaways, complaints, and so on. In some case, Officers and Cossacks were also the subject to trial for drunkenness and violation of moral and ethical norms.

Key words: Military court commission, escape, Danube (Novorossiysk) Cossack army.

Олена Бачинська

ORCID: https://orcid.org/0000-0003-0496-5742 Доктор історичних наук, професор, зав.кафедри історії України Одеський національний університет імені I.I. Мечникова, Вул. Дворянська, 2, 65082, Одеса, Україна Olena_an@ukr.net 


\section{ЗЛОЧИНИ, ПОКАРАННЯ ТА ЇХ ВИКОНАННЯ У СТАНИЦЯХ ДУНАЙСЬКОГО (НОВОРОСІЙСЬКОГО) КОЗАЦЬКОГО ВІЙСЬКА (1828-1868 pp.)}

У статті розглядаються основні види злочинів та покарань, які розглядала комісія Військового суду при Військовому правлінні Дунайського (Новоросійського) козаџького війська. 3'ясовано, щзо в багатьох випадках до втеч зі служби козаків провокували дії офіцерів, які, як правило, не несли за такі провокації жодних покарань. У додатках до статті публікуються документи однієї зі справ козака Івана Дульдієра, вчинки якого Комісія розглядала не одноразово.

Ключові слова: злочини, козак, Дунайське військо, комісія Військового суду.

Важливого значення на сьогодні набуває питання про систему покарань, їх співвідношення та адекватність злочинам, що були скоєні. Обговорення даного питання є важливим не лише для України, але й для більшості країн світу. Це змінює погляд, як на самі злочини, так і на їхню оцінку. Інститут, що відповідає за виконання покарань, які були покладені за законодавством, що на сьогодні модернізується в Україні, має назву пенітенціарна служба. Ї̈̈ діяльність та ефективність часто залежить не лише від загальносвітових правил, кодексів і практик, але й від місцевих традицій у системі покарань та їхнього виконання. Окремі злочини морально-етичного характеру важко підлягають оцінці з точки зору правових норм, і в різний час можуть злочинами не вважатися. Актуалізує вивчення цих традицій історичний досвід, який треба вивчати, зокрема, на території України, в таких організаціях, як козацькі товариства і козацькі війська. Це воєнізовані структури, які мають чітко визначені права, обов'язки, систему покарань та їх виконання. Однак, навіть, в цих структурах мали місце відхилення від загальнодержавних правил. У зв'язку 3 цим, метою i завданням нашої публікації є показати, на прикладі однієї архівної справи, причини злочинів, їх характер і форми, постаті притягнених до відповідальності козаків, покарання та їхні виконання, що існували в реальному житті козаків, одного 3 останніх козацьких формувань XIX ст. на території сучасної України - Дунайському (Новоросійському) війську.

Дунайське козацьке військо було створене у 1828 р. із задунайських запорожців, колишніх козаків Усть-Дунайського Буджацького, Чорноморського військ, волонтерів російсько-турецьких війн кінця XVIII - початку XIX ст., відставних солдат і коронних циган. У середині 50-х років XIX ст. військо нараховувало понад 12 тис осіб, які проживали в дев'яти станицях і хуторах: Миколаївка-Новоросійська, Акмангіт, Старокозачя, Волонтирівка, Фараонівка, Михайлівка, Каїри (тепер Татарбунарський, Білгород-Дністровський, Саратський райони Одеської області та район Штефан Воде Рсспублікн Молдова). Загальне керівництво здійснював новоросійський та бессарабський генерал-губернатор. Місцеве управління здійснювалося Військовим правлінням на чолі з наказним отаманом.

За Положенням при Військовому правлінні працювала комісія Військового суду. Це не був постійно діючий орган. Комісія, збиралась в разі необхідності, за розпорядженням наказного отамана. Вона складалась 3 презуса, трьох асесорів, аудитора та писаря. Комісія розглядала суто військові справи, що торкалися службових та позаслужбових порушень військових чинів. Про стан справ вона доповідала Правлінню щотижня. Інші справи - цивільного та кримінального характеру - розглядалися місцевими повітовими судовими органами за присутності представника від війська. Після закінчення справ дії комісії припинялись, але аудитор залишався працювати у Військовому правлінні [8]. 
Станичні правління були виборними органами. Вони складались з отамана, двох суддів, писаря та фельдшера. До обов'язків станичних правлінь входила охорона станичного майна та кордонів, благоустрій, справне утримання іменних і чергових списків, метричних книг, особливо перепису малолітніх та щорічні звіти про стан станиць Військовому правлінню. В окремих невеликих хуторах, де не було станічних правлінь, призначались приказний та суддя 3 декількома десятськими, які мали поліцейські функції й підпорядковувались відповідним станичним правлінням. Крім того, в станиці Каїри ще обирався урядник для нагляду за громадським порядком [9; 11, арк. 28].

Слід зазначити, що жорстокий військовий регламент і постійний контроль військової адміністрації не давав змоги козацькому протесту виливатися у відверті зіткнення та мав, переважно, пасивний характер.

Одним з розповсюджених виразів протесту були втечі козаків зі служби та станиць. Ця форма носила хронічний характер і викликала неабияку стурбованість адміністрації.

Вже на початку формування війська у вересні 1838 р. хорунжий Д.Чорнобай повідомляв полковнику Семену Чолобітчикову про те, що він привів до ст. Старокозачя й Акмангіт близько 200 козаків, станичники звинуватили його в тому, що він привласнив надані їм кошти та провіант і відмовлялись утримувати козаків. Через це деякі козаки не “ївши по два й по три дні тікали за Дунай” [3, арк. 243; 4, арк. $52,81]$. В подальшому втечі козаків продовжувались.

Джерела зберегли чимало свідчень про факти зловживань і сваволі офіцерів та інших військових чиновників, в залежності від яких опинялися служилі козаки. Це викликало незадоволення козаків i, як внаслідок, порушення дисципліни, скарги, втечі або відкриті протести. Подібні вчинки розслідувались і давали роботу комісії Військового суду. Так, осавул Данило Голобородько і хорунжий Дем'ян Чорнобай “обмежували козаків у продовольстві», осавул Микола Фролов «робив козакам різні утиски». Зокрема, ці офіцери не додали їм продовольства на 1175 крб., продавши його «стороннім особам» [5, спр.19, арк. 146, 329]. Комісар 12-го класу Чорниський «використовував для партикулярних робіт» козаків, яких було йому виділено для охорони провіантних магазинів, а деяких «карав тілесно без пощади». Сотник Олександр Білий недодав козакам фуражних грошей та платні, карав невдоволених батогами [2, арк. 5, 47, 127, 137].

Козак Діордій Лупул, який втік $з$ дев’ятьма товаришами 3 митного Ізмаїльського кордону, пояснив так причини, що штовхнули його на такий вчинок: «... скільки вже служу, а не одержав повної платні і зараз не сподіваюсь отримати іiі, тому що вираховують за різні амунічні речі і повинен залишатися знову без.... нової одежі та обувки взамін старої». Його товариші підтвердили, що Лупул «вкрай потребував одежі і обувки так, що коли заступав на варту, то одягав полатані постоли» [5, спр.45, арк. 29, 35, 63-64].

У 1835 р. втік Дмитро Драгоман разом з трьома козаками, яких він охороняв на гауптвахті та які були арештовані за другу й четверту втечі. За розпорядженням новоросійського та бессарабського генерал-губернатора Д. Драгоман після того як його спіймали, був покараний 100 ударами палок. Арештований в тому ж році за другу втечу козак Іван Блинар був прогнаний крізь стрій в 500 чоловік [7, спр. 9, арк.10 зв.]. Сваволю над козаками чинили не лише офіцери на службі, але й чиновники в станицях. В 1836 р. козак ст. Миколаївка Іван Сгоров скаржився наказному отаману, що станичний пристав урядник Ясський вимагав, щоб він косив 
сіно для нього. Єгоров відмовився оскільки «мав заняття у своєму господарстві. Так продовжувалось декілька разів. Ясський не забув відмови і без всякої провини постійно переслідував Єгорова, арештовував і бив» [5, спр. 18, арк. 423].

Початок багатьом втечам 3 війська поклала діяльність наказного отамана Станіслава Василевського. У червні 1836 р. він писав новоросійському та бессарабському генерал-губернатору про те, що при формуванні Дунайського війська «багато козаків вступили під чужими прізвиськами та ім'ям», в зв'язку 3 тим він просив дозволу провести перевірку та поновити їх справжні прізвища. М. Воронцов схвалив ініціативу отамана. Так, у Військовому правлінні 5 червня 1836 р. виникла ціла справа під назвою «Про перейменування козаків, записаних до Дунайського війська під чужими іменами та прізвищами», вона тривала до жовтня 1844 р. [7, спр.12, арк.15; спр. 30, 1-139]. У багатьох козаків і у нелегального елемента, який ховався у станицях і сусідніх 3 ними селищах, ця перевірка викликала зрозуміле обгрунтоване занепокоєння. Серед них поширились чутки про те, що втікачів будуть повертати колишнім господарям або на старе місце мешкання. Виходом 3 такого становища для багатьох була лише втеча. За переліком на початок 1837 р. за цією справою у війську було перейменовано 77 осіб, зокрема: в кінному полку 41, пішому -25, станицях - 11 [7, спр.11, арк.1-4].

Втечі козаків продовжувались протягом усього часу “перебірки”. В 1840 р. був заарештований за втечу зі служби козак ст. Старокозачої Терентій Красовський. На допиті з'ясувалось, що справжнє його прізвище Олексій Марченко. Було наказано покарати його за втечу і «за неправдиве присвоєння собі дворянського походження». В 1842 році з Ізмаїльського митного кордону втекла за кордон група козаків 4-ї сотні 2-го Дунайського полку. Згодом наказний отаман Івана Гангардт пояснив це так: «втекло до 12 чоловік раптом. Було слідство за скаргою на утиски, але скарги не підтвердилися. Винні піддані «примірному розстрілу і пробачені. Троє померли» [5, спр. 145, арк. 39; спр.30, арк. 36-36 зв.]. Через такі втечі з кордону Дунайський полк був замінений Донськими сотнями.

Однак, відверто кажучи, наказний отаман погрішив проти істини. Утиски дійсно були і призвели до того, що у січні-лютому 1844 р. втекло за Дунай відразу 38 козаків. Це викликало серйозне занепокоєння в Управлінні новоросійського та бессарабського генерал-губернатора. Слідство було доручено капітану корпусу жандармів Міцулі і старшому ад’ютанту чергування генерал-губернатору майору Орлаю 2-му. Воно відкрило цілу низку непривабливих фактів свавілля, насильств та зловживань. Тут були і розкрадання коштів, наданих на довольство козакам, і утиски станичних отаманів, в тому числі і призначення козаків на службу не в чергу, стягнення невстановлених коштів за випас худоби козаками на станичних землях, $\mathrm{i}$ примущення виконувати, «не в залік» громадські повинності і багато іншого. Проте, ті козаки, яким не вдалося втекти, були схоплені, і як в 1842 р. були наказані «примірному розстрілу». Один 3 таких втікачів, опинившись за Дунаєм в м.Тульчі Корній Білий пригадував: «А тоді ще раз перевірка була: генерал Василевський був над дунайськими козаками ... ну, й перебирали всіх - хто панський був, так і панам відправляли, голови голили наполовину, а хто стара людина, то і пів бороди голили. Багато тоді народу сюди, в Добруджу, перейшло». Таке знущання, за свідоцтвом капітана Міцулі, було заподіяно за наказом отамана козакам Мартину Пилипчуку та Іллі Бедуненку [10, с. 270-272, 614].

Особливе занепокоєння військової адміністрації викликала можливість втеч козаків під час евакуації за Буг у зв'язку з очікуваним в період Кримської війни вторгненням ворога в Бессарабію. Командування тримало в таємниці намір оселити 
дунайців у військові поселення. Наказний отаман у бесіді 3 головнокомандуючим Південної армії Горчаковим зазначив, що «козаки жахаються i самої назви військового поселення; якщо б вони уявили, що їх намагаються повернути в регулярне військо - вони б усі повтікали. - Куди? За Дунай!» [5, спр.145, арк. 37-38]. Хоча переселення не відбулося, втечі з війська продовжувались і надалі, майже до самої його ліквідації, але в менших розмірах.

В 1857 - 1858 рр., наприклад, в комісії Військового суду війська на розгляді знаходилось дев'ять справ про втечі козаків зі служби, в тому числі справа козака Самійла Тищенка, якій втікав чотири рази і був засуджений до каторжних робіт та справи Максима Швачки і Григорія Фонарія за другу втечу [5, спр.169, арк. 45-46]. На початку грудня 1869 р. за всіма військовими підрозділами, станицями і хуторами втікачів нараховувалось 255 осіб [5, спр. 204, арк.48-178].

Цікавий матеріал дає справа Івана Дульдієра, який втік з молдавського кордону в 1864 р. До цього часу він вважався бездоганним козаком. Проте умови служби, утиски та причипки, іноді навіть «соромні» з боку керівництва полку, змусили його втікти. В цій справі є свідчення самого Івана Дульдієра, його керівників та вирок суду (див. документи до публікації). Подібне зробив і козак Дунайського полку № 1 Степан Деревицький, який в 1865 р. втік вже утретє. Перейшов до Молдавії, де записався під ім'ям Степана Новженка в рекрути. За вироком комісії Військового суду його було засуджено до шести років в арестантські роти [6, арк.128-141].

Причиною виникнення судових справ було також пияцтво і порушення норм морально-етичного характеру, але такі випадки комісія Військового суду розглядала разом із церквою. Так виникла ціла справа про незаконне життя козака ст. Михайлівка І.Голіца з М.Болазановою. Церква наклала на них єпитимію на 7 років та одружила [1, с. 873; 5, спр.58]. Справа про незаконне співжиття судді ст. Новотроїцької Гинкула та його сина Івана 3 вдовою козачкою Ф.Горбельщуковою розглядалась декілька місяців комісією Військового суду, було опитано 12 свідківкозаків станиці, внаслідок чого батька та сина Гинкулів було виправдано, а справа про поведінку вдови передана для подальшого розгляду в Кишинівську духовну консисторію [7, спр. 33, арк.86-87].

Отже, організацією, що розглядала порушення, виконувала функції суду у Дунайському козацькому війську була комісія Військового суду. Основними причиними виникнення судових справ були протести козаків проти свавілля та зловживань офіцерів і військових чиновників, що виявлялись у втечах зі служби, скаргах тощо. Суду підлягали також офіцери та козаки за пияцтво і порушення норм морально-етичного характеру.

Документи:

Документ №1. Комісія Військового суду при Новоросійському козацькому війську. 20 лютого 1868 р. Станиця Миколаӥвка-Новоросійська.

Отставному Войсковому старшине Петровському

Подсудимый Иван Дульдиер на допросе показал, что заступил на службу в 1861 году в 5-ю сотню в с. Дивизия, поначалу старшиной был Педашенко, затем Петровский. Педашенко уходя ${ }^{2}$ сказал Петровскому, что бы предоставить Дульдиеру положенный отпуск летом, но Петровский не предоставил ему летом 1861 года отпуск $^{3}$, а другие казаки только заступили - ходили в отпуск по три раза.

\footnotetext{
2 в январе 1862 года

3 [«хотя бы переодеть рубашку, которая на нем уже сгнила»] (арк.123)
} 
При Петровском выдавали неполный провиант, в каждом пайке недоставало по 10 фунтов муки, и на меру, а не на вес, как при Педашенко.

За эти слухи он ${ }^{4}$ винил Дульдиера, как старого казака, оказывал ему придирки на службе ${ }^{5}$ чему были свидетели.

В июне 1862 года Дульдиер находился на кордоне № 90. За старшего из казаков был Василий Горбенко. Он его ${ }^{6}$ попросил отпустить к родственникам в село Монаши, где хотел поменять рубашки. С ним просился Алексей Паладий, они сказали, что до утра вернуться. Но родственников он не нашел, зашел в корчму, подгулял, и уехать не мог, заснул около корчмы. Затем за ним приехали казака и Петровский потребовал к себе, где сказал, что теперь он пойман, так как без разрешения уехал. Не желая подводить Горбенка он промолчал, однако, наказали только Дульдиера.

Обычно за такие проступки казаков арестовывали на сотенном дворе при конюшни, его же особенно торжественно, при трех или четырех казаках с шашками наголо отправили под арест в этапный дом в село Дивизия. Узнал он о том, что сотенный командир хочет отдать его под суд и он задумал бежать.

\section{Документ №2. Свідчення сотенного командира Петровського. Вересень 1862 р.}

Показания сотенного командира Петровского о том, что Дульдиер просил отпуск не в станицу, а в Кишиневский или Оргеевский уезд, где была его жена, так как кратковременного отпуска было мало, Петровский ходатайствовал у командира полка, который разрешил дать отпуск в июне, когда смениться с кордона, и лошади перейдут на подножный корм. Он просил еще раз, но я не могу лезть к командиру полка беспрерывно, как он ко мне. .........

Петровский показал, что Дульдиер ушел с кордона без рзрешения и он не хотел его отдать под суд, а лишь дал распоряжение проспаться.

\section{Документ №3. Справа про периу втечу зі служби та інші незаконні вчинки Івана Дульдісра.}

В комиссию Военного суда, которая создана при Войсковом правлении Новороссийского козачьего войска.

\section{Сентенция}

После побега Дульдиер бродяжничал, затем под именем Семена Доброжана был сдан наемщиком в рекруты в Кишиневском рекрутском присутствии и зачислен в 11-й пехотный резервный батальон, расположенный в Херсоне, прослужив с 22 апреля по 18 мая 1866 года он бежал, взяв некоторые казенные вещи, прибыв в июне в город Николаев был задержан полицией.

Признать виновным в:

1. Побеги, длившимся 4 года

2. В сокрытии фамилии во время побега

3. В найме в рекруты

4. В несправедливом обвинении сотенного командира Петровского.

\section{Документ №4. 3 формулярного списока Івана Дульдієра.}

43 года, на службу вступил 1 мая 1846 году Новороссийский казачий №1 полк, был в походе на Кавказе.

\footnotetext{
${ }^{4}$ Петровский

${ }^{5}$ [«хотя тот был старый казак и знал службу многих молодых лучше»] (арк.123)

${ }^{6}$ Горбенка
} 
Имеет бронзовую медаль на Андреевской ленте в память войны 1853-1856 годов, нашивки за беспорочную выслугу 10 лет.

До побега аттестовался отлично.

HАРМ. - Ф. 1048. - On.1. - Спр. 25. Арк. 123 - 260.

\section{Джерела та література:}

1. Бурьянов А. Историко-статистическое описание церкви и прихода селения Волонтировки, бывшей казачьей станицы Аккерманского уезда // Кишиневские епархиальные ведомости. 1877. - № 20.

2. Державний архів Одеської області. - Ф. 1. - Оп 218 (1831). - Спр. 8.

3. Державний архів Одеської області. - Ф. 1. - Оп 218 (1828). - Спр. 9а.

4. Державний архів Одеської області. - Ф. 1. - Оп 218 (1832). - Спр. 4.

5. Комунальна установа “Ізмаїльський архів". - Ф. 755. - Оп. 1. - Спр. 98.

6. Національний архів Республіки Молдова. - Ф. 1048. - Оп.1. - Спр. 150.

7. Центральний державний історичний архів у м.Київ. - Ф.245. - Оп.1.

8. Полное собрание законов Российской империи. Собрание II (далі - ПСЗРИ.ІІ). 1844. СПб., 1845. - Т.XIX. - № 18526.

9. ПСЗРИ.ІІ. Т.ХХХІV. 1859. - СПб., 1860. - № 54535.

10. Положение крестьян и крестьянское движение в Бессарабии. 1812-1861 гг. Сб. Документов. - Ч. 2 // История Молдавии: Документы и материалы. - Кишинев, 1969. - Т. III. 11. Російський державний військово-історичний архів. - Ф. 4л. - Оп. 138. - Спр. 87.

\section{References:}

1. Bur'yanov, A. Istoriko-statisticheskoye opisaniye tserkvi i prikhoda seleniya Volontirovki, byvshey kazach'yey stanitsy Akkermanskogo uyezda. Kishinevskiye eparkhial'nyye vedomosti. 1877. № 20. [in Russian]

2. Derzhavnyy arkhiv Odes'koyi oblasti (The State Archives of the Odessa region (Ukraine)). F. 1. Op 218 (1831). Spr. 8. [in Russian]

3. Derzhavnyy arkhiv Odes'koyi oblasti (The State Archives of the Odessa region (Ukraine)). F. 1. Op 218 (1828). Spr. 9a. [in Russian]

4. Derzhavnyy arkhiv Odes'koyi oblasti (The State Archives of the Odessa region (Ukraine)). F. 1. Op 218 (1832). Spr. 4. [in Russian]

5. Komunal'na ustanova «Izmayil's'kyy arkhiv» («Izmail Archive»communal institution (Ukraine)). F. 755. Op. 1. Spr. 98. [in Russian]

6. Natsional'nyy arkhiv Respubliky Moldovy (The National Archive of the Republic of Moldova).

F. 1048. Op.1. Spr. 150. [in Russian]

7. Tsentral'nyy derzhavnyy istorychnyy arkhiv v m.Kyyiv (Central State Historical Archives of Ukraine in Kyiv), F.245.Op.1. [in Russian]

8. Polnoye sobraniye zakonov Rossiyskoy imperii. Sobraniye II (PSZRI.II). 1844. SPb., 1845.

T. XIX. №18526. [in Russian]

9. PSZRI.II. T. XXXIV. 1859. SPb., 1860. № 54535. [in Russian]

10. Polozheniye krest'yan i krest'yanskoye dvizheniye v Bessarabii. 1812-1861 gg. Sb. Dokumentov. Ch. 2. Istoriya Moldavii: Dokumenty i materialy. Kishinev, 1969. T. III. [in Russian] 11. Rosiys'kyy derzhavnyy viys'kovo-istorychnyy arkhiv (Russian Central State Military Historical Archive (Russia)). F. 41. Op. 138. Spr. 87. [in Russian]

Отримано:02.12.2020 p. 
ISSN 2519-2523 (print)

Chornomors'ka mynuvshyna. - 2020. - No.15

DOI: $10.18524 / 2519-2523.2020 .15 .218686$

УДК 929Комаров:82-6 “189/192”

\title{
LETTERS TO ODESA RESIDENT MYKHAILO KOMAROV FROM ST. PETERSBURG, MOSCOW, KUBAN AND OTHER REGIONS OF THE RUSSIAN EMPIRE OUTSIDE UKRAINE, AS A MANIFESTATION OF THE CONSOLIDATION OF THE NATIONAL MOVEMENT AT THE TURN OF THE XIX AND XX CENTURIES
}

\author{
Taras Honcharuk \\ ORCID: https://orcid.org/0000-0002-0119-0227 \\ DSc (History), Professor \\ Odessa I.I.Mechnikov National University \\ 2, Dvoryanska Str., Odessa, 65082, Ukraine \\ tarasiy2004@ukr.net
}

Letters to the Odesa bibliographer, writer and public figure Mykhailo Komarov (1844-1913) from the collection of manuscript fund of the Odessa National Scientific Library are examined in the publication. The letters written by the authors from the lands outside Ukraine within its modern borders, but within the territory of the former Russian Empire, are analyzed. In particular, letters from St. Petersburg and Moscow, including letters of such famous scientists and cultural figures as D. Yavornytskyi, D. Mordovets, O. Lototskyi, P.Stebnytskyi and others are examined. Letters to M. Komarov from the Kuban, in particular from Ya. Bihdai, M. Dykariv, V. Skyda and others; from the Voronezh province from B.Poznanskyi; from Ryazan province from H.Machtet, from Moldova from K.Shram; from Siberia from A. Fisun and others are also analyzed. It is emphasized that the cooperation in the exchange of printed materials and the promotion of Ukrainian-language publications and Ukrainian studies publications in various regions of the country, despite censorship prohibitions were the important factors for communication between Ukrainian cultural figures at the turn of the XIX-th and XX-th centuries. The article contains the texts of fourteen letters to M. Komarov from thirteen persons from the different regions of the empire. The texts of these letters indicate that one of the leading topics in the publishing and other spheres of the cultural national Ukrainian movement in the Russian Empire of this period were the study and the popularization of the history of the Ukrainian Cossacks and its leaders. In the investigation the author makes the conclusion that it is necessary to publish as soon as possible, with appropriate comments, of all letters to $M$. Komarov from the manuscript fund of the Odessa National Scientific Library - about 1000 shits - to provide to wider range of researchers opportunities for comprehensive analysis of their content.

Key words: M. Komarov, Odesa Hromada, Odesa Prosvita.

Тарас Гончарук

ORCID: https://orcid.org/0000-0002-0119-0227

Доктор історичних наук, професор

Одеський національний університет

імені І.І. Мечникова

Вул. Дворянська, 2, Одеса, 65082, Україна

tarasiy2004@ukr.net 


\section{ЛИСТИ ДО ОДЕСИТА МИХАЙЛА КОМАРОВА 3 ПЕТЕРБУРГУ, МОСКВИ, КУБАНІ ТА ІНШИХ РЕГІОНІВ РОСІЙСЬКОЇ ІМПЕРІЇ ПОЗА МЕЖАМИ УКРАЇНИ, ЯК ПРОЯВ КОНСОЛІДАЦЇ̈ НАЦІОНАЛЬНОГО РУХУ НА ЗЛАМІ XIX TA XX CT.}

В публікації розглядаються листи до одеського бібліографа, письменника та громадського діяча Михайла Комарова (1844 - 1913 рр.) зі збірки, щсо міститься у рукописному фонді Одеської національної наукової бібліотеки. Аналізуються ті листи, щчо були написані авторами зі земель поза межами Украӥни в ї̈ сучасних кордонах, але в межах теренів тодішньої Російської імперії. Зокрема, розглядаються листи написані з Петербургу та Москви. В тому числі такими відомими вченими та культурними діячами, як Д. Яворницький, Д. Мордовечь, О. Лоточький, П. Стебницький та ін. Розглядаються листи написані до М. Комарова з теренів Кубані, зокрема, Я. Бігдая, М. Дикаріва, В. Скидана та ін. Також листи написані авторами з Воронезької губернї - Б.Познанським, Рязанської губернії - Г. Мачтетом, Молдови - К. Шрамом, Сибіру - А. Фісуном та ін. Наголошується, що важливими факторами для комунікації між українськими культурними діячами на межі ХІХ та XX cm. були співпрачя щчодо обміну друкованою продукиією та сприянню виходу в світ україномовних та українознавчих видань в різних регіонах країни попри цензурні заборони. До статті подано тексти чотирнадияти листів до М. Комарова від тринадцяти діячів 3 різних регіонів імперії. Тексти вказаних листів свідчать, щчо одну з провідних тем у видавничій та інших сферах культурницького національного украӥнського руху в Російській імперії вказаного періоду займало вивчення та популяризачія історії украӥнського козацтва та постатей його провідників.

В розвідиі робиться висновок про необхідність якнайскорішої публікаиії, з відповідними коментарями, усього масиву листів до М. Комарова з рукописного фонду ОННБ - близько 1000 аркушів - для надання ширшому колу дослідників можливостей комплексного та всебічного аналізу їхнього змісту.

Ключові слова: М.Комаров, Одеська «громада», Одеська «Просвіта».

Збірка листів до визначного українського бібліографа, письменника та громадського діяча Михайла Комарова (1844 - 1913 рр.), що зберігається у рукописному фонді Одеської національної наукової бібліотеки, привертала та продовжує привертати інтерес істориків та літературознавців. Їй, в тій чи іншій мірі, вже присвячено десятки наукових публікацій (за браком місця ми тут їх згадувати не будемо) й зацікавленість дослідників вказаною збіркою не зменшується. Це не дивно, адже в ній вміщені тексти листів до М. Комарова від двохсот осіб серед яких були як визначні українські діячи кінця XIX - початку XX ст. (I. Франко, М. Грушевський, М. Міхновський, Є. Чикаленко та ін.), так і постаті маловідомі або практично невідомі дослідникам минулого. Тексти листів були передруковані свого часу машинкою та розташовані за абеткою в залежності від прізвищ авторів (за цим же принципом розташовані тексти кількох листів зі збірки в кінці цієї публікації).

Окрім іншого, в збірці листів до М. Комарова вражає географія місця їхнього написання. В ній представлені листи з десятків населених пунктів Наддніпрянської та Західної України, країн Свропи, а також теренів Російської імперії поза межами України. Останні ми коротко розглянемо в цій публікації за географічним принципом.

Низка листів до М. Комарова було надіслано зі «столиць» імперії - Петербургу та Москви. Зокрема, листи 1883-1894 рр. від українського громадського діяча та археолога Вільгема Беренштама, який в цей час жив та викладав в гімназіях Петербургу. В листах подавалася інформація про діяльність Д. Багалія, стосунки М. Костомарова, О. Потебні, В Антоновича на науково-видавничій ниві й про 
цензурні утиски проти видання «Зорі» та проти українського культурництва загалом [3, арк. 23-29]. У збірці присутні листи від українського поета, перекладача та видавця Кесаря (Цезяря) Білиловського надіслані з Петербургу та пізніше - 3 Мітави. Один 3 останніх наводимо у додатках (див. додаток 3). В ньому, між іншим, йдеться про книжку М. Комарова «Оповідання про Антона Головатого та початок Чорноморського козацького війська» петербурзького видання 1901 р. Питання підготовки цього видання до друку розглядалися в листуванні М. Комарова 3 українським письменником, науковцем та громадським діячом Олександром Лотоцьким, який на початку XX ст. працював та мешкав у Петербурзі (див. додатки 6 та 7). В листах згадується, що обкладинку для цієї книги робив «д. Ждаха» (див. додаток 7), вочевидь, мається на увазі «д.[обродій] Ждаха» - видатний український художник та графік Амвросій Ждаха. У збірці також вміщено тексти широкого масиву листів до М.Комарова 3 Петербургу 1898 - 1910 рр. українського громадського та культурного діяча Петра Стебницького переважно про видання та поширення української друкованої продукції, проблеми 3 цензурою та ін. Нижче наведено текст одного з них (чи не найменшого за обсягом), в якому також йдеться й про підготовку до видання вищезгаданої книги М. Комарова (див. додаток 11). Низку листів 3 Кисловодську та Петербургу надіслав М. Комарову український та російський письменник Данило Мордовець [3, арк. 134-142]. У додатках вміщено текст першого з цих листів (див. додаток 9), де, між іншим, згадується журнал «По суше и морю» - своєрідний друкований орган одеської української «громади». В збірці також вміщені інші листи до М. Комарова 3 Петербургу, зокрема, П. Солоділова (між ними, цікавий лист 1906 р. про перспективи українських видань, та необхідність публікації перекладів світової класики на українську мову [4, арк. 76]), П. Гейцига, що хотів отримати портрет М. Комарова для своєї колекції портретів визначних діячів імперії [1, арк. 46-47] та ін.

Серед листів збірки М. Комарова отриманих одеським діячом з Москви варто згадати надісланий ветеринаром Сергієм Вагановим (див. додаток 4) та істориком Дмитром Яворницьким (див. додаток 14). 3 останнього видно 3 якою повагою ставився до точки зору М. Комарова визначний дослідник минулого запорозького козацтва (у збірці представлено ще кілька листів до М. Комарова від Д. Яворницького) [6, арк. 45-49].

Низка листів були надіслані до М. Комарова $з$ теренів компактного проживання українців поза межами України: з Кубані, воронезької Слобожанщини, Донщини. Це, зокрема, лист від відомого кубанського збирача українського фольклору Якима Бігдая, де він повідомляє про свої успіхи в обходженні цензури (дивись додаток 2), листи (з Воронежу та Кубані [2, арк. 75-77]) від відомого фольклориста Митрофана Дикаріва (один 3 них подано у додатку 5), листи відомого українського кубанського діяча Володимира Скидана щодо видань 3 козацької історії та зображень козацьких отаманів на пам'ятнику Катерині II тощо [4, арк. 61-71] (один з них подано у додатку 10), лист кубанського бібліографа В. Шамрая (див. додаток 12). Також у збірці вміщені тексти листів відомого українського діяча Бориса Познанського 1896 р. 3 Острогозька («Острогожське», як писав сам Познанський) Воронезької губернії [4, арк. 18-25], в яких розглядалися перспективи видань україномовної продукції й ставлення до неї місцевої «еліти» (наприклад, Б. Познанський писав: «О це недавно був у мене князь Урусов - адвокат... побачив Киівську Старину i каже: Сепарастический журнал получаете») [4, арк. 18-25]. Збирач українського фольклору 
3 Донщини Терентій Безшлях звертався до М. Комарова $з$ проханням надіслати томи його російсько-українського словника (див. додаток 1).

Присутній у збірці й лист відомого українського та російського письменника та революціонера Григорія Мачтета з Рязанської губернії. Показово, що в ньому теж йдеться про одеське українофільське видання «По морю и суше» (див. додаток 8). Деякі листи, тексти яких вміщені у збірці, були написані М. Комарову з Молдови. Зокрема, це листи українських акторів, які гастролювали у Кишиніві та досить патріотичний лист К. Шрама (Костя Іващенко), що вміщений у додатках (див. додаток 13). Є серед текстів листів збірки М. Комарова й ті, що були написані в далекому Уралі та Сибіру. Наприклад, листи Михайла Боровського доля якого занесла з бессарабського Болграду, аж до уральського Ірбіту [2, арк. 78-81]. Або листи скульптора Г. Фішеля 3 Томську, який вирішив взяти участь у конкурсі проектів пам'ятника Т.Шевченка (якого скульптор називав не інакше, як «генальным певцом Украйны») і якому М. Комаров надсилав необхідні друковані матеріали щодо життя та творчості поета [5, арк 49-52]. Також у збірці є короткий текст листа арештанта Антона Фісуна від 10 жовтня 1910 р. він писав М. Комарову: «Прохав книжок прохав і грошей і ніхто нічого не дав тепер звертаюся до Вас прошу надіслати книжок і запомогу грішми алчущій і жаждущій як на те так і на друге. Перше всього Кобзаря послідне видання...». Адреса цього листа: «Село Александровское Иркутской губ. Центральная Каторжная Тюрьма арестанту Антону Фисуну» [5, арк 48].

Вміщені у збірці з фондів ОННБ листи до М. Комарова зайвий раз засвідчують наявність процесів консолідації діячів українського національного руху на зламі XIX та $\mathrm{XX}$ ст. не лише у межах українських земель, але й поза ними. Одеські діячі відігравали в цьому процесі одну з провідних ролей. Листи до М. Комарова зі збірки ОННБ, що нараховують понад тисячу аркушів надрукованого тесту, попри наявність десятків наукових публікацій ним присвячених, потребують подальшого наукового вивчення. А передусім вони потребують публікації, на яку вони вже чекають понад сто років.

Документи:

Документ №1. Лист Т. Безиляха. 1902 р. Ростов-на-Дону.

«Ростов н/д 8 декабря 1902 г.

Выбачайте, що я прозвыща не знаю Вашого ймення, хоч и соромно украинским читатчам не знати его. Хочу я Вас ось про що прохаты. Е в мене частына «РосійськоУкраинського словаря» лыш вид А до К - те що «Зоря» змогла выслати в Россію покы небула заборонена. А бачыв я у пана Жарка у Мариуполи повный такый словарь - значить сей словарь писля «Зори» був допущен в Россію, але я того не знав. Так оце я - до Вас, як о чоловика, которому можлыво бильш ниж усякому другому: чи не зможете Вы дистать для мене повный такий словарь, хоч почынаючи вид К, хоч вид А, не вважаючи на те, що у мене е до К. Запевне у Вас, у Одесси, е зайвий, то будьте ласкави, звистить мене якым робом можете /коли можете/ выслать его мени и яка йому цина. А як що нема, то чы не можете дистати з-за кордону - я чув, що Вам те можлыво. Выбачайте за турботу, та коли б я мав змогу сам прыдбав его, а то не знаю навить куды кынутись и де его пытати. Мени про Вас яко украинского передовыка и либерала, казав видомый Вам Антин Фысун /Бог его зна де вин тепер повертаеться/, то я - осмилывся обернутись оце до Вас 3 надіею, що Вы в такій нужди поможете мени. Ще раз прошу: выбачайте.

Адрес: Ростов н/д. страховое общество «Россия» Т.Т.Безшляху.

Щыро прыхыльный до Вас Т.Безшлях» 


\section{Документ №2. Лист Я. Бігдая. 1896 р. Кубань.}

«Якось Ви мені писали про ту гемонську цензуру, та так налякали, що я думав - думав, а далі й рішив: - «хай вона собі сказиться». Ходить біля неі, тіко гріха наберешся, лучше не показуватися, так і зробив, як ви сами бачете із книжок, котрі Вам по приязні презентую. Як воно все вийшло побачете із книжок. Цензура не полізе, бо це «наукове видання», до 2-му тому, Воно ж к тому «войскове». Як був наш отаман у царя на коронаціі, то царь його спитав: «ащо будуть у вас які небудь видання»? Отаман сказав - «постораімося». - От ми і постарались, а тепер один экземпляр і посилаем царю. Як що от царя буде «яке слово», то нужно буде понести його так, щоб усіх ваших цензорів аж у носі закрутило. Предполагалось, i внесено в сміту, котру утвердив военний министр, що відання це буде войскове, т.е. на войскові гроші, но... грошей нехватило. Упустить такого для украінськоі мови случая, нехотілось і я іздав на свій кошт. На Кубані вони пішли здорово, но нужно помочі і од Вас, так как, я думаю поскоріше випустить і іще випуска три чорноморськіх пісень, а потім, під цією же ученою оболочкою «матеріали» й перейти до пословиц, казок, анектодів і творів.

Як що прівітаете цей збірник, то діло піде, а ні - мабуть духу не хвате. Лінейські поміщени во 1-х для сравнения, а во 2-х, щоб непривьязались за «разрешаю печатать», так як половина кубанців - лінейці, а тому же і празновали юбилей, по хоперскому полку.

Маю надію, що ви і пером і слововм поможете цему начатку. Поставить це діло, т.е. мій широкий заголовок - «матерьяли к ізученію Кубанскої області» треба поскоріше, бо наш, дуже щірий отаман, я йому і посвятив, може перевестись, а тоді - начинай знову. Я послав книжки в Вороніж вашому братові, Харьков - Багалію, Київ - Антоновичу і Олени Косич. Як що ви переписуетесь 3 ними, то замовте і од себе добре слово. Здорово лаятся за корректуру не треба, бо печаталось на курьерскіх; потім все це справитця.

Пішіть стіко экземплярів нужно буде для Одеси то по адресу прямо вишлють із Москви от Гроссе, щоб не пересилатця сюди й туди.

Жду от Вас ласки і привіта. Як що піддержете заворушившуся Кубань, то й для Вас буде лучше.

Може ще кому із наших пріязників послать книжки? Напишіть.

А Бігдай. 25/IX - 1896»

\section{Документ №3. Лист Ц. Білиловського. 1901 р. Мітава.}

Вельми шановний Михайло Хведоровичу.

«Митава 29/IV 1901 р.

Велике Вам спасибі за Ваш гарний подарунок - книжку про Головатого. Звеселив мене не так ваш подарунок, як памьять Ваша об мені. От вже 3-ій рік минає, як я силю тута межі німці та латишів сам-самотний, забутий від усіх. Вперве Ви оце згадали про мене і любого гостинця прислали. Вельми мині жо вподоби Ваше оповідання. Написано просто, цікаво і легко. Немає ні викрутасів, ні вигадок, ані словокручених вистругив. Отак самісенько оповідав би і Омелько і Панас і Овсій і другі дядьки або діди у селі.

А ще й добре і гаразд зробили, що именно про Головатого написали. Згадали людім про часи славетні, про діі незабутні. Змалювали велику і дуже зрушливу трагедію - смерть, нагальну смерть Единих того часу на світі лицарів. Вичитав і довго-довго думав сумуючи, $\mathrm{i}$ сумував, думаючи. Що за чудовий и вдячний матерьял за для драми чи трагедіi. Одна постать Головатого чого коштує. Які сцени напрошуються. От де за для творчості простір безкраій, а за утвір хороший слава в народі.

Що-ж ище, дорогий Михайло Хведоровичу, Вам сказать? Нічого хорошого, нічого веселого! Велике горе спіткало мене. Сього лютого поховав я мою квітку-доньку, котру Ви бачили у мого брата ув Одесі. А з нею в купі двох ще синів Юрка і Миколу /Юрка знає Олексій/ - всіх від скарлатини, що вніс мені у хату один хворий хлопчик-латиш.

Писати нічогісенько не пишу. Часто набігають на мене думки, часто сумую, задріжить i загуде у серці якась ледаща струна, здається, викричав-би на весь світ жалощі моі, - i тільки похитає головою, махну рукою і знов заціпну, знов німий! Мині рідних людей треба, рідної 
мови, рідного повітру, рідноі землі - знов би сили набравсь, зкинув-би кригу з себе і пішовби пінявою хвилею, покотився-би, поринув-би, миючи і низини 3 калиновими кущами i скелисті береги з крутими бескидами.

Ще раз спасибі, Цілую Вас здалека так саме, як і в Одесі цілував.

Також і Олеся.

Ваш К.Білиловський.»

ОННБ. РКП 28/1. - Арк 21, $29-30,53-54$.

\section{Документ №4. Лист С. Ваганова. 1900 р. Москва.}

Щиро поважаемий Михайло Хведорович.

«17.XII. 900 г.

Ви мабуть трохи здивуетесь одібравши цей лист, але я николи не викидав Вас 3 свого серця, з своіх думок, а від того зад для мене не було б незвичайним, як би я одібрав Вас лист, хоч проминуло не мало часу, як я й перестав читати Ваші до мене листи. Не листи звязують людей, а те - чим іх серце сповнено: на листі ж вони добром до рідної украіни. Обертаюсь до Вас от $з$ яким ділом. Скажіть на милість - чи Ваша цензура розріша до печаті на нашій мові наукові брошури. Мені оце вчора повернули з Питра рукопись и С.П-скій цензур К-т розішив дрюкувати мою брошуру «Розмова про Сухоти рогатоі худоби. Яка ця болість і як від неі боронитись». Не знаю, як і де іі дрюкувати. Кийане казали в осени, що вони надрюкують, а проте хто его зна. Може Ви знаете, як це діло зробити і як кийане не зможуть, то тоді згожусь на Вашу пораду. Як що ця праця сподобиться Вам, то маю надію написати про «Сказ, телій, сап и др. хвороби. Я тут познаемився з п. Яворницким, людина страшено щира, поіхав оце в Катеринодар читати про своіх запорожців. Написав він де-що про Ваш словарь : я ему радів одіслати до Вас и те що написав і ті слова /900/ котріх не долічує він з свого боку в вашім словарі. Він з цією думкою згодився, мабуть так і зробе. Словарь Ваш він ліче кращою настольною книжкою.

Будьте ласкаві пришліть мені Ваш словарь Руссько-Укр. наложним платежем по ардес: Москва. М.Бронная, д. Гирш, кв. №71, буду щиро дякувати, бо в наших московских книгарнях словаря Вашего нема, а на юг не приходилось зіздить. Я чув від братка, що Ваша Віруся вийшла заміж - щасти-ж ій доля. Як же ви поживаете, ваше здоровьячко. За кутею, котра у нас завжди робиться по звичаю любоі старини, ми згадаемо Вас і тепер, як згадуемо, що року, бо кажу - Вас николі не забуваю. Всім Вашим щире бажанье здоровья, а 3 новим роком ще кращого, веселого житья!

Обнімаю Вас и щирими вустами цілую - кріпко, кріпко, щоб нихто Вас так кріпко не поцілував на новий рік, як щиро до Вас прихільний.

С. Ваганов».

\section{Документ №5. Лист М. Дикаріва. 1897 р. Катеринодар.}

Високоповажний Добродію Михайле Федоровичу!

«Катеринодар 2.II.97.

Заходившись писати Вам листа після довгого мовчання, я не знаю, с чого й почати. Почну с патрета Т.Г.Шевченка, що разом з сим засилаю Вам. Се вже копія з копії, і до того через лад блідної: тим-то патрет вийшов невдатним. Первовзір був знайдений д.Волошиним, тепер совітником Обласного Правленія, під час його перебування в Київськім університеті у одного $з$ «старих громадян».

Про свої роботи подам от-що. Зараз в «Этногр. Обозр» друкується моя велика розправа п.з. «По поводу народных толков 1896 г. о царских загацках». Се загацки х приводу коронації про відберання від панів землі на користь селянам. Додатки до сеї розправи будуть етнографічні матеріали, зібрані мною перевагом на Чорноморіи. Я маю починити де-які виводи на підставі сих матеріалів і все надрукувати в «Етнологичнім Збірнику» Наук. Тов. ім. Шевч. п.з. «Народна поголоска з поводу коронації 1896 р.». 
Вам мабуть вже відомо, що в т. II «Етногр. Збірн.» надруковані мої «Чорноморські казки й анекдоти».

Далі стоїть на черзі друкованннє моїх вороніжських етнологічних матеріалів, котрих у мене назбіралось мабуть аркушів на 1000 писаних. Багато буде мороки над впорядкуванням їx. Думаю почати виданнє з народного акушерства і родин з хрестинами, а тоді вже перейду до дитячого життя. Всі от сі матеріали маю друковати в Галиччині.

Тепер збіраються мані відомості про народну гутірку з поводу одноденної статістичної переписи. Словом сказавши, я, мовляв, стараюсь бути в курсі сучасного народного життя.

Сей рік звичаєм попередніх років роковини Т.Г.Шевченка будуть святкуватися тут роздачою бідним міщанам його «Кобзаря». Перший рік було роздано 10 примірників, придбаних моїм власним коштом, торік 15 примірників - на зібрані гроші, і сей рік на такі-ж гроші буде роздано 24 примірники. Такий спосіб святкування я вважаю найбільш відповідним істоіті свята, ніж визволяннє шинкарів по панських шинках.

На-сам-кінець скажу Вам, що ось уже два роки як ни покидає мене клятий чорноморський «корчій». Багато я витратив грошей на ліки і все марно. Літом того року я на місяць їзди до Новомосковського, і там тільки чув полегкість. Вже 3 самого виїзду 3 Катеринодару наче як одрізало, і так було, поки я не звернувсь знов сюди. За два роки хвороби з мене став такий робітник, як батіг 3 клоччя, цілі тижні і місяці проходять у мене без ніякої роботи. Так от же я поклав мерщій куди [...] втікати з гнилої Кубані, аби тільки на Україну. Том удаюся Вас з уклінною просьбою: коли почуєте про яку підхожу службу, будьте ласкаві повідомте мене.

Не знаючи жодної одеської книгарні потурбую Вас ще одною уклінною прозьбою: будьте ласкаві надіщліть мені 3 наложеною: «Матеріали по етнографії нововроссійського края» В.Н.Ястребова.

3 глибоким поваженнєм до Вас М.Дикарів» (II арк 78 - 79)

ОННБ. РКП 28/2. - Арк. 2-3, $78-79$.

\section{Документ №6. Лист О. Лотоцького. 1901 р. С.-Петербург.}

«Високоповажний Михайло Федоровичу.

Дозволяю собі турбувати Вас в справі заповіту О.Я.Кониського, мені він заповів права літературної власності на всі свої твори - друковані і недруковані, а разом постановив мене душеприкащиком що-до свого майна, яке він заповів здебільшого закордонним українським інституціям. Що до першого заповіту - про літературну власність, то річ безперечна, що він буде затверджений. Але другий заповіт - що-до маєтку, то родина небіщика захожується его оспорювати. На ведення судової справи потрібні кошти, а в мене на жаль їх немає. От я і дозволяю звернутися 3 сією справою до Вас на той случай, коли не небіщикові О.Я. Кониському належить що одержати за видання его творів - українських та «жизнь укр. поэта Т.Г.Шевченка». Коли справді належить ему що небудь, то я просив би дати мені $з$ того яку дещицю на ведення справи - рублів 100- 150. Коли одержу от Вас відповіді, то перешлю Вам нотаріальну копію заповіту, який може бути потрібним для «Ю.-Р. Общества печатного дела».

Прошу і сподіваюся на скору Вашу відповідь, - бо думаю скористуватись масляницею та поіхать в Киів, аби посунути справу. Зараз я служу в Петербурзі.

«Головатий» друкується і може за тиждень буде готовий. Після того піде брошура «Про сухоти на хворобі» Ваганова, а там буде «Богдан Хмельницький». Поталанило нам на Богданів - дозволено аж три: крім Вашого, - ще Кулішів та I.С. Левицького.

Два дальших томів «Віку» вже в цензурі; єсть ще там три тому «Української бібліотеки» (твори Руданського, Свіцького та Кримського) і кілька добрих народних брошюр. Петербурзьке «Благотв. Общ.» вдається до цензури 3 проханням, аби ему безборонно дозволялися медичні популірні брошюри.

3 глибоким поважаннєм О.Лотоцький.

СПбург. 1901.I. 29. Мойка, 76.» 


\section{Документ №7. Лист О. Лотоцького. 1901 р. С.-Петербург.}

«Щироповажний Михайло Федоровичу.

Посилаю Вам малюнки д.Ждахи, як про се ми умовились.

«Богдан» вже в друкарні, але ледве чи появиться він раніше, як через місяць, бо дуже затягується справа $з$ малюнками. Хотілося б дуже дати хоч 10 малюнків і для того переглянув я всі периодичні і ілюстровані видання російські, думаючи там знайти щось відповідне, та дарма. Зараз маємо вже готовий портрет Богдана і памятник ему; ждемо 3 Киіва малюнки Переяславської ради та Суботівської церкви - і не тому здається, буде край, бо більш нічого здобуть не можна. Чи не маєте Ви чого такого? Чи не придатний би був який 3 малюнків до «Чорної ради»? Коли дасте яку раду, то я просив би не одмовити скорою відповіддю.

Посилаємо д. Ждасі его проект малюнка для обкладинки з нашими увагами, як він хотів того. Коли б він за два тижні прислав свій малюнок, то та обкладинка встигла б ще захопити «Богдана», що було б дуже бажано.

Зараз маємо готових три брошури, але затягується їх випуск через ріжні причини. «Оповід. про Т.Шевченка» затягується теж через малюнки; на сім тижні його випускаймо. «Виноград» та «Сухоти на худобі» давно готові, але ждуть санкції Міністерства хліборобства. В наборі і - «Виговщина». Друкарня не може зараз стільки рукописів держать в наборі - через те треба буде «Богдана» одддать у другу друкарню.

Я Вам маю послати тих 50 р., що взяв було з книгарні «Київ. Старини», за третій том О.Я.К., сподіваючися, що небіжчик О.Я.Кониський видав третій том цілком за свої кошти. Переписавши для цензури 4 і 5 дальші томи, я витратив сі гроші і прошу Вас, чи не згодилися б ви взяти належні Вам 100 р. за третий том з цих грошей, що будуть в книгарні від продажі сего решту - після 1 січня 1901 р. Дуже прошу мене сповістити. Був би вдячен, коли б ви додали ще до речи чи не потеланило Вам здобути яку посаду для бідолахи Чернявського.

З глибоким побажаннєм О.Лотоцький».

\section{Документ №8. Лист Г. Мачтета. 1896 р. Зарайськ.}

«г. Зарайск. 12 марта 1896 г. Рязанск. г.

Очень благодарю редакцию за доброе, ласковое слово, радуюсь, что группе хороших людей удалось взять в свои руки хотя бы маленький журнал и обещаю непременно прислать что нибудь в этом же году. За последнее прошу выслать мне журнал «По суше и морю» (г.Зарайск, Рязанск. губ. мне) и в особенности прошу, как услуги, за которую буду крайне признателен, достать для меня Шевченковский номер галицкой «Зори».

С искренним признанием и пожеланием всего хорошего.

ОННБ. РКП 28/5. - Арк 76, 113.

Григорий Мачтет»

\section{Документ №9. Лист Д. Мордовцева. 1896 р. Кисловодськ.}

«Кисловодск, 5-VII-96

Між морями гори хмарою повиті, Засіяні горем, кровію политі...

Щире шановний добродію-земляче!

Ви вже знаєте «Складку», що спорудив К.А.Біліновський, й привітали вже цю українську «ластівку» (не «метелика», а цілу «ластівочку») добрим словом. Спасибі за ласку, а пишуть до мене - що Ви, добродіє, й мене старого привітали в часописі - «По морю й суше».

Тепер д. Білило пише до мене про свою сварку з Л.О.Григоровим і благає, щоб і я був радником у цій сварці та й Вас вельми запрошує про те. Порадьте, добродію, Григорову - не доводить бідної «ластівочки» до суду, до гласности, до скандалу, щоб у «заплаканої матері» від сорому щічки не загорілись. Д.Білило просе, щоб і лист до Григорова (копію) я заслав до 
Вас. Засилаю. Зробіть, що зможете: Ваше слово послухається, бо воно буде словом щирого земляка. неньки.

Бувайте здорові на користь «заплаканої матері», бо Ви - не одцурались од старої

А я оце за - весну й літо написав (Ваша рада) історичний роман «Дві долі», - таки чималенький - аркушів 320 й більше друку.

Щиро прихильний Данило Мордовець».

ОННБ. РКП 28/5. - Арк 134.

\section{Документ №10. Лист В. Скидана. 1896 р. Катеринодар.}

Многоуважаемый Михаил Федорович!

«Екатеринодар 9 июля 96 г.

На Ваше письмо от 22 июня, собрав всякие справки от лиц вполне компетентных, могу ответить следующее. Портрет Головатого два года тому назад искали для книжки «Кубанское казачье войско» (изд. 1888 г.) и нигде не могли найти. Изъездили хутора, обыскали церковь Головатого в Тамани - и напрасно. Напали на след у наследников генеральши Зинченко, но пока этот след ни к чему не привел. Советуют искать в тех церквях, где он был ктитором, до переселения, между прочим в Новомосковске.

Поночевный - ученик Вл.Б.Антоновича (хорошо ему известный) говорит, что песнь «чорна хмара наступає» приписуют Головатому. И за тем его те две песни, о которых Вы пишите. Больше ничего не известно. Тот же Поночевский сообщает, что у Вл.Б он видел некий сборник статей, между которыми есть статья о Головатом, где прекрасно описана наружность Головатого. Статья больше анекдотическая. Затем в записках Одесского Общества истории есть несколько статей о военных подвигах, между прочим характерный отзыв Головатого о священнике Ковалевском. В Таманской церкви много подарков Головатого - блюдо, евангелие и пр.

У Мовы не был и думаю, что всего лучше будет, если Вы сами ему напишите. О Вашей работе я ему подробно рассказывал при первом с ним свидании. После того у него не был, встречаюсь случайно. Вот все, что могу сообщить по интересующим Вас вопросам. Теперь о своих делах. Прилагаемые деньги прошу передать Лаон А. как мой долг за прошлый год. Прошу у него извинения за неаккуратность. Осенью еще пришлю. Просите его выслать мне отчет о ночлежных приютах. Весьма обяжете.

Предполагал я, как Вам писал, устроить здесь книжную лавочку на имя сестры. Но это дело разстроилось, по семейным обстоятельствам. Продолжаю мечтать если не о книжной торговле в далеком будущем то хоть о комиссии. Спрос на книжки есть, а предложения мало. Как вы об этом думаете? С какой уступкой можно будет получать из Киева и Одессы? При первых свободных 100 руб, выпишу, если столкуюсь с местными книготорговцами. Перетолкуйте, при случае, с кем нужно по этому предмету. Поклон всему Вашему семейству и всем общим знакомым.

Жму Вашу руку Вл. Скидан».

ОННБ. РКП 28/6. - Арк $61-62$.

Документ №11. Лист П. Стебницького. 1900 р. С.-Петербург.

«15 жовтня $1900 \mathrm{p}$.

Вельми шановний Михайло Федоровичу.

Поперед усього порадую Вас доброю звісткою: сьогодні взяв я з цензури «Антона Головатого» дозволеного до друку. Хвалить Бога - якось проскочив. Отже тепер кажіть що 3 цим робити: чи починать друкувати тут, чи Ви хочете самі цього діла доглянути $\mathrm{i}$ видрукувати, і взагалі, як Ви думаєте поставити матеріальну сторону видання. Коли можно, не баріться, будь-ласка, з відповіддю, бо у нас поки що це одна готова рукопис, що вже можно друкувати, - а то або в цензурі, або ще не подані. 
Зараз же подам Богдана, побачим як він пройде.

Подане оповідання Кониського - «Смерть предателя» (що у III томі) прокляті цензори направили в духовну цензуру, а там зараз же поставили заборону, звичайно без всяких мотивів. 3 цього вивожу, що така ж доля буде і Вашого Кирила з Мефодієм; через те поки що не буду його подавати - нехай виясниця.

Чом не присилаєте нам обіцяних 170 карб. 3 офіціяльною бумагою? Шліть на ймення голо - Д.Л.Морд. (Столярний пер. 6).

Давайте рукописів коли єсть готові.

Писала Кулішиха, що малюнки до «Чорної Ради» вже вийшли 3 цензури. Я надзвичайно радий. Присилайте ж нам примірників 15 або 20 простих і не менш як 103 малюнками. [...]

Вже більше місяця як я вернувся в Петербург, та не міг до Вас обізватись; не пощастило мені в подорожі: захопив десь аж за кордоном натуральну віспу (лиш дуже легеньку), приїхав хворий і мусив ще кілька часу вилежати в шпиталю. Оце тижнів до два як приступив до своїх справ та потроху даю лад тому, що набралося за літо.

Бувайте здоровеньки; низько кланяюся Вам і Вашій родині. Пишіть же, будь ласка. Що нового? Чи балакали з Мах.?

Щиро приязний і шануючий Вас П.Стебницький».

ОННБ. РКП 28/7. - Арк $16-17$.

Документ №12. Лист В. Шамрая. 1902 р. Катеринодар.

«Милостивый Государь Михаил Федорович.

Узнав, что Вы работаете в одной со мной области литературного труда (библиография), с удовольствием посылаю Вам по экземпляру печатных своих последних трудов и льщу себя надеждою, что вы не откажете поделиться со мною и своими.

С истинным почтением Ваш покорнейший слуга В.Шамрай.

20/II - 1902

Екатеринодар. Кубанское Областное Правление».

\section{Документ № 13. Лист К. Шрама К. [1904 р.] Тирасполь.}

«Тирасполь 22 IX

Любий усім нам Михайло Федорович!

Тильки що прочитав довгу, дуже цікаву і доладу написану статтю про те, що діялось в Москві на з'їзді земців і горожан. Говорили про самостайне життя різних народів - поляків, кавказців, фінів. Радісно відкликались на надію Польши, Кавказа, Финляндіи мати «у своїй землі свою волю и правду»; навіть говорили про бурят...

А де ж ми були? Що робили наші люде? Не вже сиділи по закутках та чекали, може і про нас згадають ї нам щось дадуть? Один тільки Максим Ковалевський щось натякнув про те, що Украінські де-які землі боролись за автономне життя майже з II віку, та й замовк. Боже, Боже, не вже 200 літне духовне безхлібе і безліте нас так знівечили, що в такий случний стан, який тепер переживаем, серед нас не нашлось ні одного чоловіка що поіхав би в Москву і одстояв наші чоловічі і національні права перед репрезентантами усіеї Росіі. Які ж ми несчасні раби.... Простіть, що так пишу, не я пишу: у мене все болить од думки, що не стало у нас волі і розуму за себе говорить там, де треба».

\section{Документ № 14. Лист Д. Яворницького. 1899 р. Москва.} «18 IV/22 99

Москва, Зарядье, Кривой пер., д. Бахрушина

Вельми поважний Михайло Хведорович!

Дуже дякую Вас за Ваш щирый та прихильний до мене лыст! А я таки прызнаюсь Вам, подумав, що добри люде цураются мене, и гирко-гирко зробылось у мене на души... «За що и як»? думаю соби. Нехай у мене там талану историка нема, так хиба як за це уже и 
зневажити чоловика? Та як бы ж там хто другый мене зневажыв, а то ж такы КомаровУманець? Мабуть, багато чого у мене непрыемного, що люде цураются мене... Так от так, голубчику, спасыби Вам сердешне за Ваш лист!...

Надсилаю Вам мою рукопис «Максым Мыкытович Витряк». Те що таменькы розскажетця, було як есть так $з$ чоловиком, и тут моего твору дуже мало. Одно тильки й скачу Вам, що ци лысты розмов, яки есть у рукописи, запысаны бильш усего коло могыл, як от то я у литку копаю их та веду балачку 3 копачамы. Есть таки оброты, що мени и не прынадать таких; то Вы не дивуйтеся тому; есть и слова таки, якых зроду вику до моих мандривок по Запорожжу не чував. Одначе, Вы, голубе мій, вычытайте усе с особшою увагою, видчеркнить те усе, що Вас здается негаразд, оливцем (а не пером), розсмакуйте мого Витряка и всих его сынов добре, подумайте над там, чи вирно в мене списана природа, и скажить мени напослыдок правду, щыру, свыту правду. Памьятайте те, що як мій твир некчемный, то я тым й скинчу, - бильш такого не пысатыму; а як що Вы прызнаете его добрым, то я ще попробую себе на историчний хроници добы кошового Сирка. Самому мени багато чого не подобаеться, и я уже кильки разив рвав мого «Витряка» на шматки, а от то мисяцив за тры, як перепысав його так и покинув не чытаючы, - може чи есть и прогалыны. Бильш усього не подобаетця мени та глава, де Павлусь Витряченко (штундыста) выявляе злодійства нашых попив (XVII), в ній нема художества, а зате есть щыра правда, и через це мени шкода ый выкынуты. Кажить же мени усе, и я послухаюсь Вас, яко знатока украинскои мови и творчества.

Серцем Ваш Д.Эварницкий.

Першого мая я выіду до Петрограда, и як що Вы до того чысла не встыгнете вычытаты мою рукопись, то надишлить ій такій адреси: Его Прев-у Гофмейстру Высочайшего Двора Георгию Петровичу Алексееву. Угол Сергиевской ул. И Воскресенского просп., д. Зейфарта для передачи Д.И.Эвар-у».

Джерела та література:

1. Одеська національна наукова бібліотека (далі ОННБ). РКП 28/1.

2. ОННБ. РКП 28/2.

3. ОННБ. РКП 28/5.

4. ОННБ. РКП 28/6.

5. ОННБ. РКП 28/8.

6. ОННБ. РКП 28/10.

References:

1. Odeska natsionalna naukova biblioteka (next ONNB). RKP 28/1.

2. ONNB. RKP 28/2.

3. ONNB. RKP $28 / 5$.

4. ONNB. RKP 28/6.

5. ONNB. RKP 28/8.

6. ONNB. RKP 28/10.

Отримано: 05.12.2020 p. 
ISSN 2519-2523 (print)

DOI: $10.18524 / 2519-2523.2020 .15 .218954$

УДК 2-9

\title{
ACTIVITIES OF THE “COMMISSIONER FOR THE RUSSIAN ORTHODOX CHURCH AND RELIGIOUS CULTS AT THE COUNCIL OF PEOPLE'S COMMISSARS OF THE USSR IN ODESSA" IN 1944-1965 (by materials of the State archives of Odessa region)
}

\author{
Maksym Dubna \\ ORCID: https://orcid.org/0000-0002-2661-0144 \\ Head scientific researcher \\ The State Archives of Odessa region \\ 18, Zhukovskogo str., Odessa, Ukraine, 65026 \\ maks.dubna98@gmail.com
}

The article analyzes the activities of the "Commissioner for the Russian Orthodox Church" and "Correspondence on Religious Cults" at the Council of People's Commissars of the USSR in Odessa region in 1944-1958, found unique photos from both Odessa and Odessa region destroyed, converted and rebuilt churches, chapels, houses of worship.

The mechanism of repressive pressure on worshipers and religious communities in the issue of renovation and re-registration of churches, etc. has been studied. The principle of identification and accounting of temple buildings and communities is shown.

Key words: orthodox church, religion, cult, cult buildings, commissioners, Odesa, Odesa region.

Максим Дубна

ORCID: https://orcid.org/0000-0002-2661-0144

Головний науковий співробітник

Державний архів Одеської області

вул. Жуковського, 18, Одеса, 65026, Україна

maks.dubna98@gmail.com

\section{ДІЯЛЬНІСТЬ «УПОВНОВАЖЕНОГО У СПРАВАХ РОСІЙСЬКОЇ ПРАВОСЛАВНОЇ ЦЕРКВИ ТА РЕЛІГІГІЙНИХ КУЛЬТІВ ПРИ РАДІ НАРОДНИХ КОМІСАРІВ УРСР ПО ОДЕСЬКІЙ ОБЛАСТІ В 1944-1965 РОКАХ» (за матеріалами Державного архіву Одеської області)}

У статті проаналізована діяльність «Уповноваженого у справах російської православної иеркви» та «Переписка по справах релігійних культів» при Раді Народних Комісарів УРСР по Одеській області в 1944-1958 роках», виявлені унікальні фотокартки,як одеських так й з тодішньої території Одеської області зруйнованих, перетворених $i$ перебудованих иерков, капличок, молитовних домів. Досліджений механізм репресивного тиску на служителів культу та власне релігійних громад у питанні поновлення та перереєстрачї храмів тощчо. Показаний принщии ідентифікації та обліку храмових споруд та громад.

Ключові слова: православна церква, релігія, культ, культові споруди, уповноважений, Одеса, Одеська область. 
У грудні 1965 р. в Радянському Союзі розпочинає свою діяльність Рада у справах релігій «рос. - Совет по делам религий». Вона була створена після Хрущовської антирелігійної кампанії, у результаті якої відбулося злиття двох органів підвідомчих Раді міністрів СРСР - Ради у справах Російської православної церкви (утвореної 14 вересня 1943 року) і Ради у справах релігійних культів (утвореної 19 травня 1944 року) [7, с. 414].

Справи діяльності саме цих двох органів було виокремлено з фонду Р-2000 «Одеський обласний виконавчий комітет», так би мовити фонд у фонді, а саме в описах №3 та 5 за період існування вищеописаних установ 1944-1965 рр.,виявлені наступні справи:

Уповноважений у справах Російської православної церкви

\begin{tabular}{|c|c|c|c|c|c|}
\hline $\begin{array}{c}\text { Фонд } \\
\text { № } \\
\end{array}$ & $\begin{array}{l}\text { Опис } \\
\text { № }\end{array}$ & $\begin{array}{c}\text { Спр. } \\
\text { № }\end{array}$ & $\begin{array}{c}\text { Назва справи } \\
\text { (мовою документа) }\end{array}$ & Роки & $\begin{array}{c}\text { Кількість } \\
\text { аркушів }\end{array}$ \\
\hline P-2000 & 3 & 6 & $\begin{array}{c}\text { «Уполномоченный по делам } \\
\text { православной иеркви» }\end{array}$ & $1945-1952$ & $10,16,24$ \\
\hline P-2000 & 3 & 99 & $\begin{array}{c}\text { «Переписка с православными } \\
\text { иерквями и монастырями о } \\
\text { регистрачии иерквей и др. } \\
\text { вопросам» }\end{array}$ & $\begin{array}{l}03.11 .1945- \\
10.12 .1952\end{array}$ & 135 \\
\hline P-2000 & 3 & 170 & $\begin{array}{c}\text { «Переписка с Советом } \\
\text { республиканским } \\
\text { уполномоченным и местными } \\
\text { организациями по вопросу } \\
\text { религии» }\end{array}$ & $\begin{array}{l}13.12 .1946- \\
10.12 .1952\end{array}$ & 409 \\
\hline P-2000 & 3 & 171 & $\begin{array}{c}\text { «Материаль епархиального } \\
\text { управления духовной } \\
\text { семинарии и др.» }\end{array}$ & $\begin{array}{l}21.11 .1946- \\
18.10 .1952\end{array}$ & 185 \\
\hline P-2000 & 3 & 260 & $\begin{array}{c}\text { «Переписка по русской } \\
\text { православной черкви и } \\
\text { молитвенных домов» }\end{array}$ & $\begin{array}{l}17.05 .1947- \\
17.09 .1952\end{array}$ & 148 \\
\hline P-2000 & 5 & 25 & $\begin{array}{c}\text { «ереписка по вопросам } \\
\text { русской православной черкви» }\end{array}$ & $\begin{array}{c}01.01 .1944- \\
02.06 .1944\end{array}$ & 2 \\
\hline P-2000 & 5 & 42 & $\begin{array}{c}\text { «Переписка по делам русской } \\
\text { православной церкви» }\end{array}$ & $\begin{array}{l}12.01 .1945- \\
20.12 .1945\end{array}$ & 70 \\
\hline P-2000 & 5 & 64 & $\begin{array}{c}\text { «Переписка по делам русской } \\
\text { православной церкви» }\end{array}$ & $\begin{array}{l}18.02 .1946- \\
24.01 .1947\end{array}$ & 154 \\
\hline P-2000 & 5 & 79 & $\begin{array}{c}\text { «Переписка по делам русской } \\
\text { православной церкви» }\end{array}$ & $\begin{array}{l}18.01 .1947- \\
31.12 .1947\end{array}$ & 227 \\
\hline P-2000 & 5 & 104 & $\begin{array}{c}\text { «Переписка по делам русской } \\
\text { православной церкви» }\end{array}$ & $\begin{array}{c}01.01 .1948- \\
31.12 .1948 \\
\end{array}$ & 272 \\
\hline P-2000 & 5 & 129 & $\begin{array}{c}\text { «Переписка по русской } \\
\text { православной иеркви и } \\
\text { епископе Никоне» }\end{array}$ & $\begin{array}{l}21.09 .1949- \\
30.12 .1949\end{array}$ & 57 \\
\hline P-2000 & 5 & 130 & $\begin{array}{c}\text { «Переписка по делам русской } \\
\text { православной церкви» }\end{array}$ & $\begin{array}{c}06.01 .1949- \\
31.12 .1949 \\
\end{array}$ & 164 \\
\hline P-2000 & 5 & 164 & $\begin{array}{c}\text { «Переписка по делам русской } \\
\text { православной церкви» }\end{array}$ & $\begin{array}{c}01.01 .1050- \\
30.12 .1950\end{array}$ & 136 \\
\hline
\end{tabular}




\begin{tabular}{|c|c|c|c|c|c|}
\hline P-2000 & 5 & 196 & $\begin{array}{c}\text { «Переписка по делам русской } \\
\text { православной ияеркви» }\end{array}$ & $\begin{array}{c}05.01 .1951- \\
11.12 .1951 \\
\end{array}$ & 122 \\
\hline P-2000 & 5 & 219 & $\begin{array}{c}\text { «ереписка по делам русской } \\
\text { православной ичеркви» }\end{array}$ & $\begin{array}{c}01.01 .1952- \\
30.12 .1952 \\
\end{array}$ & 192 \\
\hline P-2000 & 5 & 243 & $\begin{array}{c}\text { «Переписка по делам русской } \\
\text { православной ичеркви» }\end{array}$ & $\begin{array}{c}06.01 .1953- \\
26.12 .1953\end{array}$ & 117 \\
\hline P-2000 & 5 & 260 & $\begin{array}{c}\text { «Переписка по делам русской } \\
\text { православной иеркви» }\end{array}$ & $\begin{array}{c}05.01 .1954- \\
27.12 .1954\end{array}$ & 133 \\
\hline P-2000 & 5 & 275 & $\begin{array}{c}\text { «Переписка по делам русской } \\
\text { православной ичеркви» }\end{array}$ & $\begin{array}{c}05.01 .1955- \\
30.12 .1955 \\
\end{array}$ & 212 \\
\hline P-2000 & 5 & 289 & $\begin{array}{c}\text { «Переписка по делам русской } \\
\text { православной ичеркви» }\end{array}$ & $\begin{array}{c}09.01 .1956- \\
18.12 .1956 \\
\end{array}$ & 160 \\
\hline P-2000 & 5 & 307 & $\begin{array}{c}\text { «Переписка по делам русской } \\
\text { православной ицеркви» }\end{array}$ & $\begin{array}{c}07.01 .1957- \\
24.12 .1957 \\
\end{array}$ & 324 \\
\hline P-2000 & 5 & 331 & $\begin{array}{c}\text { «Переписка по делам русской } \\
\text { православной цееркви» }\end{array}$ & $\begin{array}{c}21.01 .1958- \\
19.12 .1958 \\
\end{array}$ & 115 \\
\hline P-2000 & 5 & 347 & $\begin{array}{c}\text { «Материаль по делам } \\
\text { русской православной } \\
\text { иеркви/Постановления } \\
\text { Совета, информацчи и др.» }\end{array}$ & $\begin{array}{c}10.01 .1959- \\
07.12 .1959\end{array}$ & 136 \\
\hline P-2000 & 5 & 365 & $\begin{array}{c}\text { «Материаль по делам } \\
\text { русской православной } \\
\text { иеркви/Постановления } \\
\text { Совета, информачии и др.» }\end{array}$ & $\begin{array}{c}12.03 .1960- \\
19.12 .1960\end{array}$ & 203 \\
\hline P-2000 & 5 & 380 & $\begin{array}{c}\text { «Материаль по делам } \\
\text { русской православной } \\
\text { иеркви/Постановления } \\
\text { Совета. информачии и др.» }\end{array}$ & $\begin{array}{c}02.01 .1961- \\
25.12 .1961\end{array}$ & 100 \\
\hline P-2000 & 5 & 396 & $\begin{array}{c}\text { «Материаль по делам } \\
\text { русской православной } \\
\text { иеркви/Постановления } \\
\text { Совета, отчеть, } \\
\text { информаччи и др.» } \\
\end{array}$ & $\begin{array}{c}08.01 .1962- \\
15.12 .1962\end{array}$ & 155 \\
\hline P-2000 & 5 & 406 & $\begin{array}{c}\text { «Материальы по делам } \\
\text { русской православной } \\
\text { церкви/сведения, информации } \\
\text { и др.» }\end{array}$ & $\begin{array}{c}01.01 .1963- \\
31.12 .1963\end{array}$ & 9 \\
\hline P-2000 & 5 & 417 & $\begin{array}{c}\text { «Материаль по делам } \\
\text { русской православной } \\
\text { иеркви/постановления } \\
\text { Совета, информаччи и др.» }\end{array}$ & $\begin{array}{c}26.06 .1963- \\
31.12 .1963\end{array}$ & 35 \\
\hline P-2000 & 5 & 428 & $\begin{array}{c}\text { «Материальы по делам } \\
\text { русской православной } \\
\text { иеркви/постановления } \\
\text { Совета, информации и др.» }\end{array}$ & $\begin{array}{c}01.01 .1963- \\
31.12 .1963\end{array}$ & 152 \\
\hline
\end{tabular}




\begin{tabular}{|c|c|c|c|c|c|}
\hline P-2000 & 5 & 438 & $\begin{array}{l}\text { Материаль по делам русской } \\
\text { православной церкви/справки, } \\
\text { сведения, информации и др.» }\end{array}$ & $\begin{array}{c}24.03 .1964-12.1964 \\
31.106\end{array}$ & 227 \\
\hline P-2000 & 5 & 448 & $\begin{array}{l}\text { Материаль по делам русской } \\
\text { православной церкви/отчеть, } \\
\text { сведения, информачии и др.» }\end{array}$ & $\begin{array}{c}09.01 .1965- \\
31.12 .1965\end{array}$ & \\
\hline
\end{tabular}

Уповноважений у справах релігійних культів

\begin{tabular}{|c|c|c|c|c|c|}
\hline $\begin{array}{l}\text { Фонд } \\
\text { № }\end{array}$ & $\begin{array}{c}\text { Опис } \\
\text { № }\end{array}$ & $\begin{array}{c}\text { Спр. } \\
\text { № }\end{array}$ & $\begin{array}{c}\text { Назва справи } \\
\text { (мовою документа) }\end{array}$ & Роки & $\begin{array}{l}\text { Кількість } \\
\text { аркушів }\end{array}$ \\
\hline P-2000 & 3 & 7 & $\begin{array}{l}\text { «Уолномоченный по делам } \\
\text { религиозных культов» }\end{array}$ & $1945-1956$ & $\begin{array}{l}10,17,24,31, \\
38,78,88 .\end{array}$ \\
\hline P-2000 & 3 & 100 & $\begin{array}{l}\text { «Переписка по делам } \\
\text { религиозных культов» }\end{array}$ & $\begin{array}{c}06.07 .1945- \\
06.09 .1946\end{array}$ & - \\
\hline P-2000 & 3 & 172 & $\begin{array}{c}\text { «Переписка по вопросам } \\
\text { религиозныхх культов с Советом } \\
\text { по делам религиозных культов } \\
\text { при Совете Министров СССР» }\end{array}$ & $\begin{array}{l}12.01 .1946- \\
11.12 .1947\end{array}$ & 50 \\
\hline P-2000 & 3 & 173 & $\begin{array}{c}\text { «Переписка о религиозной } \\
\text { общине Молокан» }\end{array}$ & $\begin{array}{c}20.06 .1946- \\
18.12 .1946 \\
\end{array}$ & 17 \\
\hline P-2000 & 3 & 174 & $\begin{array}{c}\text { «Религиозные общества снятые } \\
\text { с регистрации» }\end{array}$ & $\begin{array}{l}16.02 .1946- \\
26.11 .1952 \\
\end{array}$ & 139 \\
\hline P-2000 & 3 & 175 & «тоже» & $\begin{array}{c}01.05 .1946- \\
01.03 .1956\end{array}$ & 39 \\
\hline P-2000 & 3 & 176 & «тоже» & $\begin{array}{c}09.08 .1946- \\
07.08 .1950\end{array}$ & 236 \\
\hline P-2000 & 3 & 177 & 《тоже» & $\begin{array}{c}15.10 .1946- \\
17.11 .1948\end{array}$ & 105 \\
\hline P-2000 & 3 & 178 & «тоже» & $\begin{array}{l}01.06 .1946- \\
20.10 .1951\end{array}$ & 124 \\
\hline P-2000 & 3 & 261 & $\begin{array}{l}\text { «Переписка по вопросам } \\
\text { религиозных культов» }\end{array}$ & $\begin{array}{c}09.01 .1947- \\
17.09 .1947\end{array}$ & 51 \\
\hline P-2000 & 3 & 343 & $\begin{array}{l}\text { «Переписка по вопросам } \\
\text { религиозных культов» }\end{array}$ & $\begin{array}{c}10.01 .1948- \\
13.07 .1948\end{array}$ & 45 \\
\hline P-2000 & 3 & 344 & «тоже» & $\begin{array}{c}10.02 .1948- \\
16.02 .1948\end{array}$ & 46 \\
\hline P-2000 & 3 & 345 & 《mоже» & $\begin{array}{c}20.01 .1948- \\
20.11 .1948\end{array}$ & 88 \\
\hline P-2000 & 3 & 462 & $\begin{array}{c}\text { «полномоченный по } \\
\text { религиозным культам } u \\
\text { религиозные общества снятые с } \\
\text { регистрачии» }\end{array}$ & $\begin{array}{c}21.05 .1949- \\
02.11 .1949\end{array}$ & 172 \\
\hline P-2000 & 3 & 1087 & $\begin{array}{c}\text { «Переписка о религиозных } \\
\text { культах и религиозные } \\
\text { общества, которым отказано в } \\
\text { регистраиии» }\end{array}$ & $\begin{array}{c}23.11 .1953- \\
06.12 .1956\end{array}$ & 148 \\
\hline P-2000 & 3 & 1219 & $\begin{array}{c}\text { «кты сдачи дел религиозных } \\
\text { обществ перешедиих в }\end{array}$ & $\begin{array}{c}30.06 .1954- \\
06.07 .1954\end{array}$ & 5 \\
\hline
\end{tabular}




\begin{tabular}{|c|c|c|c|c|c|}
\hline & & & $\begin{array}{c}\text { Николаевскую } и \\
\text { Кировоградскую области» }\end{array}$ & & \\
\hline P-2000 & 5 & 43 & $\begin{array}{c}\text { «Переписка по делам } \\
\text { религиозных культов» }\end{array}$ & $\begin{array}{l}07.01 .1945- \\
31.12 .1945\end{array}$ & 53 \\
\hline P-2000 & 5 & 55 & $\begin{array}{c}\text { «Переписка по вопросам } \\
\text { религиозных культов» }\end{array}$ & $\begin{array}{c}07.01 .1946- \\
13.12 .1946\end{array}$ & 90 \\
\hline P-2000 & 5 & 80 & $\begin{array}{c}\text { «Переписка по делам } \\
\text { религиозных культов» }\end{array}$ & $\begin{array}{l}26.12 .1946- \\
25.11 .1947\end{array}$ & 121 \\
\hline P-2000 & 5 & 103 & $\begin{array}{l}\text { «Переписка по делам } \\
\text { религиозных культов» }\end{array}$ & $\begin{array}{c}01.02 .1948- \\
31.12 .1948\end{array}$ & 165 \\
\hline P-2000 & 5 & 128 & $\begin{array}{l}\text { «Переписка по делам } \\
\text { религиозныхх культов» }\end{array}$ & $\begin{array}{c}06.01 .1949- \\
31.12 .1949\end{array}$ & 159 \\
\hline P-2000 & 5 & 163 & $\begin{array}{l}\text { «Переписка по делам } \\
\text { религиозных культов» }\end{array}$ & $\begin{array}{c}01.01 .1950- \\
30.12 .1950\end{array}$ & 143 \\
\hline P-2000 & 5 & 195 & $\begin{array}{l}\text { «Переписка по делам } \\
\text { религиозных культов» }\end{array}$ & $\begin{array}{c}08.01 .1951- \\
29.12 .1951\end{array}$ & 133 \\
\hline P-2000 & 5 & 218 & $\begin{array}{l}\text { «Переписка по делам } \\
\text { религиозных культов» }\end{array}$ & $\begin{array}{c}12.01 .1952- \\
23.12 .1952 \\
\end{array}$ & 184 \\
\hline P-2000 & 5 & 242 & $\begin{array}{l}\text { «Переписка по делам } \\
\text { религиозныхх культов» }\end{array}$ & $\begin{array}{c}06.01 .1953- \\
16.12 .1953\end{array}$ & 113 \\
\hline P-2000 & 5 & 259 & $\begin{array}{c}\text { «Переписка по делам } \\
\text { религиозных культов» }\end{array}$ & $\begin{array}{c}19.01 .1954- \\
30.12 .1954 \\
\end{array}$ & 71 \\
\hline P-2000 & 5 & 276 & $\begin{array}{l}\text { «Переписка по делам } \\
\text { религиозных культов» }\end{array}$ & $\begin{array}{l}05.01 .1955- \\
28.12 .1955\end{array}$ & 202 \\
\hline P-2000 & 5 & 288 & $\begin{array}{c}\text { «Переписка по делам } \\
\text { религиозных культов» }\end{array}$ & $\begin{array}{c}02.01 .1956- \\
29.12 .1956 \\
\end{array}$ & 278 \\
\hline P-2000 & 5 & 306 & $\begin{array}{l}\text { «Переписка по делам } \\
\text { религиозных культов» }\end{array}$ & $\begin{array}{c}02.01 .1957- \\
31.12 .1957 \\
\end{array}$ & 292 \\
\hline P-2000 & 5 & 330 & $\begin{array}{c}\text { «Переписка по делам } \\
\text { религиозных культов» }\end{array}$ & $\begin{array}{c}11.01 .1958- \\
16.12 .1958\end{array}$ & 194 \\
\hline P-2000 & 5 & 348 & $\begin{array}{c}\text { «Материаль по делам рели- } \\
\text { гиозных культов/ постановле- } \\
\text { ния Совета, информацчи и др./» }\end{array}$ & $\begin{array}{c}06.01 .1959- \\
20.12 .1959\end{array}$ & 199 \\
\hline P-2000 & 5 & 364 & $\begin{array}{c}\text { «Материаль по делам рели- } \\
\text { гиозныхх культов/постановления } \\
\text { Совета, информации и др./» }\end{array}$ & $\begin{array}{c}09.01 .1960- \\
27.12 .1960\end{array}$ & 163 \\
\hline P-2000 & 5 & 381 & $\begin{array}{c}\text { «Материаль по делам рели- } \\
\text { гиозных культов/постановления } \\
\text { Совета, информацчи и др./» }\end{array}$ & $\begin{array}{c}02.01 .1961- \\
04.09 .1961\end{array}$ & 274 \\
\hline P-2000 & 5 & 382 & $\begin{array}{c}\text { «Материаль по делам рели- } \\
\text { гиозныхх культов/постановления } \\
\text { Совета, информации и др./» }\end{array}$ & $\begin{array}{c}06.09 .1961- \\
25.12 .1961\end{array}$ & 156 \\
\hline P-2000 & 5 & 397 & $\begin{array}{c}\text { «Материальы по делам религио- } \\
\text { зныхх культов/постановления } \\
\text { Совета, отчеты, информации и } \\
\text { др./» }\end{array}$ & $\begin{array}{c}03.01 .1962- \\
06.10 .1962\end{array}$ & 175 \\
\hline P-2000 & 5 & 407 & $\begin{array}{c}\text { «Материаль по делам } \\
\text { религиозных культов/сведения, } \\
\text { информации и др./» }\end{array}$ & $\begin{array}{c}01.01 .1963- \\
31.12 .1963\end{array}$ & 57 \\
\hline
\end{tabular}




\begin{tabular}{|c|c|c|c|c|c|}
\hline P-2000 & 5 & 418 & $\begin{array}{c}\text { «Материальы по делам религиоз- } \\
\text { нырх культов/планьl, отчеты, } \\
\text { информации, переписка/» }\end{array}$ & $\begin{array}{c}04.02 .1963- \\
26.12 .1963\end{array}$ & 150 \\
\hline P-2000 & 5 & 429 & $\begin{array}{c}\text { «Материаль по делам религиоз- } \\
\text { ных культов/постановления } \\
\text { Совета, информации и др./» }\end{array}$ & $\begin{array}{c}01.01 .1963- \\
31.12 .1963\end{array}$ & 89 \\
\hline P-2000 & 5 & 439 & $\begin{array}{c}\text { «Материальы по делам религиоз- } \\
\text { ных культов/ планы, отчеты, } \\
\text { информации, докладные } \\
\text { записки, переписка/» }\end{array}$ & $\begin{array}{c}07.01 .1964- \\
31.12 .1964\end{array}$ & 233 \\
\hline P-2000 & 5 & 449 & $\begin{array}{c}\text { «Материаль по делам религиоз- } \\
\text { ных культов/ отчеты, сведения, } \\
\text { информачии и др.» }\end{array}$ & $\begin{array}{c}22.01 .1965- \\
11.10 .1965\end{array}$ & 327 \\
\hline
\end{tabular}

Загалом 70 справ, із них 30 - «Уповноваженого у справах Російської православної церкви» та 40 - «у справах релігійних культів» $[1,2]$.

У ф. Р-2000, оп. 3, спр. 170 містяться унікальні відомості та фотографії церков, храмів, молитовних домів, капличок як м. Одеса, так і тодішньої Одеської області. Уповноважений Ради по Одеській області пише висновок до Виконкому Одеської Облради депутатів трудящих:

Документ №1. Лист-ухвала Виконавчому комітету Одеськой обласноӥ ради депутатів трудящих. 2 жсовтня 1950 р., Одеса.

«ИСПОЛНИТЕЛЬНОМУ КОМИТЕТУ ОДЕССКОГО ОБЛАСТНОГО СОВЕТА ДЕПУТАТОВ ТРУДЯЩИХСЯ

По вопросу снесения часовни, построенной в период

немеикой оккупачии, на Октябрьском рынке,

Кагановичского района, города Одессы

\section{ЗАКЛЮЧЕНИЕ}

Исполнительный комитет Кагановичского района, города Одессы, в связи с проводимой реконструкиией Октябрьского рынка, ходатайствует о сносе часовни, находящейся на площади Октябовского рынка.

Учитывая, что часовня, построенная в период немецкой оккупации, находится в центре площади привокзального Октябрьского рынка. В этой часовне, до середины 1947 года производилось служение молебнов, продажа свечной, крестиков и других церковных предметов, иеромонахом Ионикием, постоянно прикрепленным к этой часовне, из числа братии быв. Пантелеймоновского мужского монастыря.

В начале 1948 года, по моему совету, деятельность монастыря в этой часовне была прекращена Архиепископом Фотием. Часовня же, осталась на месте, является же совершенно не нужным сооружением среди торговых помещений государственных и кооперативных организаций торгующих на базаре.

Считаю возможным, удовлетворить просьбу Кагановичского Исполклма Райсовета депутатов трудящихся о снесении часовни, находящейся на площуади привокзального Октябрьского рынка города Одессы.

Уполномоченный Совета

По Одесской области /Благов/

«2» октября 1950 г.

2. Oдесса»

Державний архів Одеської області. Ф. Р-2000. Оп.3. Спр.170. Арк.196. 
Документ №2. Зображення часовні. Одеса.

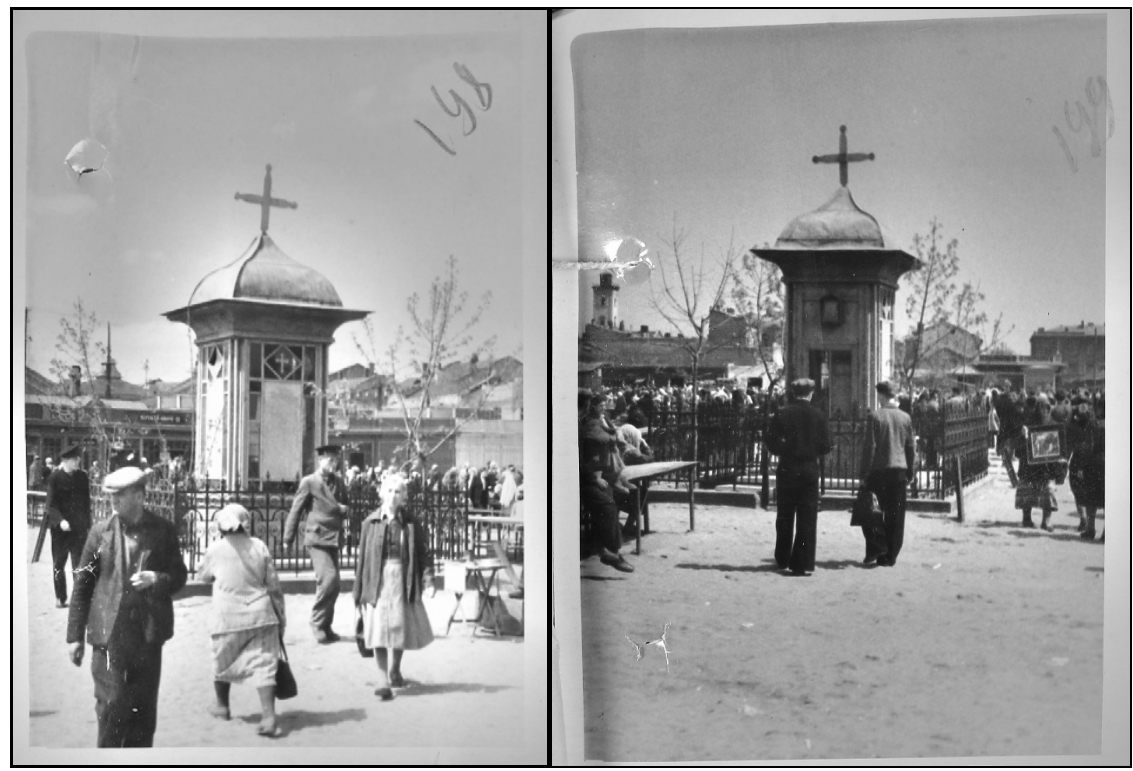

Державний архів Одеської області. Ф. Р-2000. Оп.3. Спр.170. Арк.198-199.

Документ №3. Рімення Виконавчого Кагановицького райради депутатів трудящих. 26 серпня 1950 р., Одеса.

«РЕШЕНИЕ

Исполнителкома Кагановичского Райсовета депутатов трудящихся

26-го августа 1950 2. №468 гор. Одесса

О закрытии часовни православной иеркви, находящейся на Октябрьском рынке.

В связи с реконструкцией Октябрьского рынка, для улучшения обслуживания трудящихся,- Исполком Кагановичского Райсовета депутатов трудящихся РЕШИЛ:

1. Снести часовню православной церкви с площчади Октябрьского рынка, освободив место для постройки павильонов.

2. Просить Исполком Горсовета утвердить настоящее решение.

и. о. Пред. Исполкома Кагановичского

Райсовета депутатов трудящихся

/П. СЕДЛЯРЕВИЧ/

Секретарь Исполкома Райсовета

депутатов трудящихся

/А. СПИЦИНА/»

Державний архів Одеської області. Ф. Р-2000. On.3. Спр.170. Арк.197. 
Документ №4. Рішення Виконавчого комітета Одеської обласної Ради депутатів трудящих. 13 жовтня 1950 р., Одеса.

«РЕШЕНИЕ

Исполнительного Комитета Одесского Областного Совета

Депутатов трудящихся

2. Одесса №1906/1 «13» октября 1950 года.

О снесении часовни, находящейся на привокзальной площади Октябрьского рынка, города Оессы.

Учитывая просьбу Исполнителльного Комитета Кагановичского Райсовета депутатов трудящихся г. Одессы и неуместное нахождение часовни на площади Октябрьского рынка г. Одессы, - Исполнительный Комитет Одесского Областного Совета Депутатов трудящихся РЕШИЛ:

Согласиться с заключением уполномоченного Совета по делам русской православной иееркви при Совете Министров СССР по Одесской области о снесении часовни, построенной в период немецкой оккупации, на привокзальной площади Октябрьского рынка, в Кагановичском районе, города Одессы.

Предиедатель Исполкома Обласовета

Депутатов трудящихся

/K. KAPABAEB/

Секретарь Исполкома Обласовета

Депутатов трудящихся

/И. НИКИФОРОВ/»

Державний архів Одеської області. Ф. Р-2000. Оп.3. Спр.170. Арк.195.

Справи діяльності «Уповноваженого у справах Російської православної церкви» та «Уповноваженого у справах релігійнихкультів» містять унікальні документи та матеріали які стосуються релігійного життя людей та долі культових споруд Одеського регіону в 1944-1965 pp.

\section{Джерела та літератури:}

1. Державний архів Одеської області. - Ф. Р - 2000. - Оп.3. - Спр. 170. - 162 арк.

2. Державний архів Одеської області. - Ф. Р - 2000. - Оп. 5. - 29 арк.

3. Совет по делам религий при Совете министров СССР // Атеистический словарь / под ред. М. П. Новикова. - Москва: Политиздат, 1985. - С. 414.

\section{References:}

1. Derzhavnyy arkhiv Odes'koyi oblasti (The State archives of Odessa region (Ukraine)). F. R. 2000. Op. 3. Spr. 170. 162 ark.

2. Derzhavnyy arkhiv Odes'koyi oblasti (The State archives of Odessa region (Ukraine)). F. R. 2000. Op. 5. 29 ark.

3. Sovet po delam religiy pri Sovete ministrov SSSR. In: Novikova, M. P. red, 1985. Ateisticheskiy slovar'. Moskva: Politizdat. p. 414.

Отримано: 05.12.2019 p. 
DOI: $10.18524 / 2519-2523.2020 .15 .218687$

УДК 94(477)

\title{
WHAT HISTORY SHOULD CHILDREN IN 5TH CLASS LEARN: TO THE PROBLEM OF UKRAINIAN PROPEDEUTICS
}

\author{
Taras Chukhlib \\ ORCID: https://orcid.org/0000-0002-2604-4816) \\ DSc (History), Professor \\ Institute of history of Ukraine, NAS of Ukraine \\ 4, Hrushevskoho Str., Kyiv, 01001, Ukraine \\ taras_chuhlib@ukr.net
}

[Review of the publication "Concept and programs of teaching the history of Ukraine at school" (project). Materials of IV and V Workshops on monitoring of school textbooks of Ukraine ":" Program of teaching the history of Ukraine in school. 5th class: "Introduction to History" (author N. Yakovenko). - K., Stylos Publishing House, 2009].

Тарас Чухліб

ORCID: https://orcid.org/0000-0002-2604-4816 Доктор історичний наук, провідний науковий співробітник Інституту історії України НАН України Вул. Грушевського, 4, Київ, 01001, Україна taras_chuhlib@ukr.net

\section{ЯКУ ІСТОРІЮ ПОВИННІ ВЧИТИ ДІТИ У 5-МУ КЛАСІ: ДО ПРОБЛЕМИ УКРАЇНСЬКОЇ ПРОПЕДЕВТИКИ}

[Рецензія на видання "Концеепція та програми викладання історії Украӥни в школі (проект). Матеріали IV та V Робочих нарад з моніторингу шкільних підручників Украӥни»: «Програма викладання історії Украӥни в иколі. 5-й клас: «Вступ до історї̈» (автор Н. Яковенко). - К., Видавничий дім «Стилос», 2009].

Зазначимо, що один із авторів видання «Концепція та програми викладання історії Україні в школі (проект). Матеріали IV та V Робочих нарад з моніторингу шкільних підручників України» професор Наталія Яковенко здійснила велику евристичну роботу щодо вивчення змісту більшості шкільних підручників з історії України, а також спробу продукування нових програм з історії України для вітчизняних шкіл. Запропонована Н. Яковенко «Концепція викладання історії України в школі» (далі - Концепція), на нашу думку, не зовсім відповідає засадам шкільної історичної освіти. Адже у ній простежуються положення, які можуть бути піддані сумніву.

Насамперед, дискусійними є пропоновані у завданнях Концепції тлумачення відносно того, що «історія - це відкритий процес, який не визначають наперед жодні закони» (адже світова історіографія, філософія, культурологія тощо продовують полемізувати щодо цього визначення), а учні повинні «розуміти різницю між 
історичною подією та її інтерпретацією» (с.8). І це зробити досить важко, адже по суті все те, що ми розуміємо під «історичною подією і $\epsilon$ «інтерпретацією», а різні «історичні школи» користуючись своєю методологією можуть по-різному оцінювати ту чи іншу подію.

Досить важко, на нашу думку, буде запровадити i т. зв. аксіологічну компетентність серед учнів, що передбачає «уміння формулювати оцінку історичних подій та історичних постатей, суголосну до цінностей та уявлень відповідного часу чи відповідної групи людей». 3 огляду на це викликає сумнів впровадження серед принципів історичної освіти т. зв. загальнонаукового підходу, який передбачає «ознайомлення учнів із достовірними фактами та їх інтерпретаціями 3 метою формування цілісного наукового світогляду» (с. 9). Зауважимо, що «цілісного наукового світогляду», з огляду на різні причини (головною серед яких є багатолітня відірваність вітчизняної науки від світового історіографічного процесу), на сьогодні не має не тільки переважна більшість шкільних вчителів та університетських викладачів історії, але й істориків-науковців.

Позитивним є бажання автора Концепції впровадити принцип антропологізації («олюднення») історії України, що передбачає постання в уяві учня «пластичного образу минулого в усій його різноспрямованій динаміці» (с. 10). При цьому антропологічний підхід, який «ставить в центр уваги людину», має дозволити бачити «конкретні прояви буття суспільства», що базуються на «прикладах поведінки конкретних соціальних груп» (с. 11). Також автор декларує відхід від «ідеологічно» сконструйованого минулого на користь його «реального» конструювання. Такий методологічний підхід, на іiі думку, має передбачати відмову від викладання вітчизняної історії як «ексклюзивної історії українців» на користь висвітлення історії «заселеної без перерви території», а отже поряд з антропологічним пропонується т. зв. територіальний (на відміну від «народницького/націєтворчого» та «державницького») підхід до осягнення минулого України. А чому б, наприклад, не поєднати ці три базові наукові принципи у висвітленні нашої історії?

Серед основних завдань Концепції є i методична прив'язка викладу історії України до паралельного курсу всесвітньої історії. Хоча зрозуміле бажання авторів щодо «вписування» історії України до всесвітньої історії, на нашу думку, мусить відбуватися не лише через «європеїзацію» («історія України точилася на тлі європейських процесів», с. 11 і т. ін.), але й бачення того, що українське минуле від давніх часів і до кінця XVIII ст. в усіх своїх проявах було тісно пов'язане не тільки з Свропою, але й зі Сходом (Азією, Степом, Орієнтом, Османами, Кримом), а потім - Росією (Євразією). А отже нав'язування відвертого «європоцентризму» у вітчизняному шкільному курсі $\epsilon$ неприпустимим, адже таким чином викривлюється не лише історична пам'ять учнів, а й наперед програмується ідеологічна конструкція щодо історико-культурного зверхництва Заходу як такого i, відповідно, меншовартості України як території чи держави та українців як етносу чи політичної/громадянської нації.

На прикладі пропедевтичної Програми викладання історії України в школі для 5-го власу («Вступ до історії») спробуємо довести, що пропоновані для застосування у ній методологічні принципи «антропологізації», «територіалізації» та «європоцентризму» (які на сьогодні є визнаними історичною наукою) з одного боку, лише використовуються задля механічної екстраполяції на шкільний курс історії України певних в т. ч. і «застарілих» ідеологем, а 3 іншого - тільки декларуються 3 метою впровадження суб'єктивного/авторського (в даному випадку - Н. Яковенко) бачення українського минулого. Перед тим зазначимо, що програми викладання історії в школі не повинні ототожнювати 
завдання «чистої» історичної науки з метою шкільної освіти, а особливо ії пропедевтичних предметів. Перенесення підходів, характерних для написання академічних праць чи навіть вузівських підручників до шкільних програм призводить до невмотивованої переобтяженості, недоступності, нецікавості, а звідси - низької педагогічної ефективності цих самих програм.

Серед основних критичних зауважень до Програми для 5-го класу «Вступ до історії» насамперед виокремлюються наступні.

По-перше, у ній переважає надмірна «академічність» викладу, щуо заважатиме сприймати відповідний матеріал дітьми 10- та 11-річного віку:

- приклад № 1: на уроці «Історія в географічних назвах» (Тема I) пропонується пояснення слова «топоніміка» в межах оповіді про «Локальні топонімічні легенди» (с.16). Можливо учень і запам'ятає що означають грецькі слова «місце» та «ім'я», але водночас вчителеві треба ще додатково пояснити значення слова «локальний»;

- приклад № 2: на уроці «Становлення Нової Свропи» (Тема III) передбачається вивчати «Релігійну полеміку й війни між протестантами й католиками» (с. 18). При цьому пропонується пояснити що таке «Реформація», але ж потрібно ще роз'яснити поняття «релігійна полеміка», «протестанти» і «католики» і т. ін.;

А загалом 10- та 11-річні учні протягом досить короткого шкільного курсу мають взнати про: «етимологію понять» (!?), «християнізацію іменувань» (!?), «антропонімію класу» (!?), «колективне життя», «варварські королівства», «виокремлення аристократів» (с. 16); «рицарський кодекс поведінки», «язичницьке многобожжя», «монотеїстичні релігії» (!?), «моральні цінності», «вдосконалення ремесла», «офіційну документацію», «обрядові свята» (с. 17); «культурну специфіку», «обіг інформації», «безпомильність Церкви» (!?), «міське самоврядування», «етнічну строкатість», «міський простір», «зміст новацій» (с.18); «здешевлення книжки», «розширення козацьких прав», «професійне військо», «суспільство та владу Української козацької держави» (с. 19); «Велику Французьку революцію як початок «Нової Свропи» (!?), «природнє середовище і густоту заселення», «нові погляди на націю», «національні змагання бездержавних народів». «розповсюдження поглядів на демократію» (с. 20); «прискорений розвиток промисловості», «примусову колективізацію», «винищення інтелігенції», «комуністичні перетворення», «нацистську окупацію» (с. 21) тощо. Очевидно, що такий «науковий академізм»у викладі $\epsilon$ неприйнятним та надзвичайно складним для вікових особливостей п’ятикласників.

По-друге, у Програмі передбачається викладення великого за обсягом матеріалу, його інформаційне, а відтак - змістове перевантаження:

- приклад № 1: на уроці «Мешканці давньої і середньовічної Європи» (Тема II) на с. 16 пропонується розкрити аж 12 (!) навчальних проблем: 1) «Середземномор'я як колиска європейської цивілізації»; 2) «Оповідь про греків і римлян»; 2) «Варварська» Європа за межами римської держави»; 3) «Об’єднання племен як перша форма організованого колективного життя»; 4) «Переміщення [об'єднань племен] по Свропі»; 5) «[Переміщення об'єднань племен] по Україні; 6) «Кельти»; 7) «Германці»; 8) «Слов’яни»; 9) «Велике переселення народів»; 10) «Терени розселення слов'ян»; 11) «Територія середньовічної України як історична батьківщина українського етносу»; 12) «[Територія середньовічної України як історична батьківщина] кримсько-татарського етносу».

При цьому маленьким дітям пропонується не лише засвоїти надзвичайно складний за сприйняттям і великий за обсягом історичний матеріал (а чи кожний 
вчитель може його подати у такому стислому викладі?), але й обов'язково запам'ятати, що таке «цивілізація», «варвар» та «етнос» (графа «Пояснення понять...»). Поза увагою автора програми залишається розкриття таких важливих понять, як «Європа», «римська держава» та «народи», чого учні ще не знають 3 огляду на виклад попередніх тем. Викликає зауваження й модернізаційне та певною мірою маніпулятивне положення щодо синхронізації історичної появи на території середньовічної України власне українського та кримсько-татарського етносів.

- приклад № 2: на уроці «Друга світова війна» (Тема V) на с. 21 передбачається вивчити вже 13 (!) питань: 1) «Прихід до влади нацистів у Німеччині»; 2) «Початок і перебіг Другої світової війни в Свропі»; 3) «[Початок і перебіг Другої світової війни] в СРСР»; 4) «Трагедія Голокосту»; 5) «Нацистська окупація України»; 6) «Примусове вивезення молоді на роботи до Німеччини»; 7) «Рух Опору нацистам: європейські партизани; 8) «[Рух Опору нацистам]: радянські партизани»; 9) «Визвольний український рух проти нацистів»; 10) «[Визвольний український рух проти] Радянського Союзу»; 11) «Українська повстанська армія»; 12) «Втрати українців у війні»; 13) «Внесок [українців] у перемогу над нацистами». Кожна з цих важливих історичних проблем $є$ надзвичайно серйозною з огляду на їхню постійну актуалізацію та політизацію, а тому передбачається, що вчитель у стислому режимі лише обмежиться короткою характеристикою, що неодмінно призведе до певної чи надмірної ідеологізації.

Окрім названих, великою інформативністю переобтяжені такі уроки: «Вступ» (пропоновано 10 питань для вивчення), «Відлік часу в історії» (12 питань), «Зміни у віруваннях» (10), «Винаходи й здобутки цивілізації» (11) та «Повсякденне життя людини європейського Середньовіччя» (12 питань протягом одного уроку).

По-третє, у Програмі присутня однобічність трактувань, які є авторськими $і$ в окремих випадках дуже суб' єктивними та ідеологічно заангажованими. Це ускладнює для педагога виклад матеріалу, а для учня - його сприйняття та засвоєння:

- приклад № 1: під час уроку 1-го теми II розглядається питання «Об’єднання племен як першої форми організованого колективного життя». Тут відразу ж у вчителя мають виникнути логічні питання: а можливо першою формою $є$ все ж таки об'єднання людей в «плем'я»? а може перед «племенем» були ще й інші організаційні форми? а чому ми маємо навчати дітей тільки в межах теорій Чарльза Дарвіна чи Фрідриха Енгельса і т. ін.;

- приклад № 2: під час уроку 6-го теми III розглядається питання «Стисла оповідь про козацькі повстання за розширення своїх прав». Тут не враховується та обставина, що між «козацькими повстаннями» 1591 - 1593 рр. та 1637 - 1638 рр. (хронологічна відстань майже 45 років!) відбулася значна еволюція поглядів їхніх керівників: від ідеї захисту козацьких «прав і привілеїв» до ідеї «оборони віри» українського/руського народу. Віра, в даному випадку православна, на той час була невід'ємною частиною етнічної або ж ранньонаціональної самоідентифікації більшої частини українців, а тому повстання 1625, 1630 й, особливо, 1637 - 1638 рр. можна маркувати не лише як «козацькі», але й «українські». Отже, козаки боролися не лише за «розширення своїх прав» (до речі, яких - соціальних, економічних чи може політичних?), але і від початку 17 ст. захищали право на православне віросповідання тогочасного українського етносу Корони Польської та Великого князівства Литовського.

Окрім вищеназваних у Програмі присутні й інші однобічні трактування, зокрема такі, як: 
1) «Становлення украӥнського козацтва як професійного війська: илях від Запорозькой Січі до реєстрового Війська Запорозького» (с. 19). Нагадаємо, що реєстрове українське (бо були ще суто й польські підрозділи козаків) козацьке військо у межах 1568 -1638 рр. нараховувало від 300 до 3000 осіб. Разом 3 тим, загальна чисельність нереєстрового (а, отже, «непрофесійного» за логікою автора) Війська Запорозького коливалася на середину 1630-х pp. у межах від 40 до 60000 тисяч вояків. Чому про нього немає жодної згадки? I чому маніпулятивно в учнів має створюватися враження, що козацтво творилося лише як професійне військо (що автоматично передбачає впливи на нього лише державної влади Корони Польської)? Видається, що це лише частина істини. Інша ж складова процесу одержавлення козацтва, «станова» та «політична», чомусь замовчується. Та і загалом дітям не роз'яснюється, що ж таке Запорозька Січ і на якій основі вона виникла.

2) «Причини й перебіг козацького повстання [Богдана Хмельницького]» (с. 19). Сьогодні стосовно цієї події в українській історіографії переважно вживаються означення «Національно-визвольна війна», «Визвольна війна», «Українська національна революція», «Козацька революція» та ін., але майже ніхто не маркує їі як «козацьке повстання». Адже поняття «козацьке» в даному випадку значно звужує сприйняття учнями 5-го класу справді революційних подій середини 17 ст. Яким був етнічний склад повсталого козацтва? Які претензії (а серед них були не лише «станові» вимоги) вони висували до владних структур Корони Польської? Якими були причини чергового «повстання» і чим воно відрізнялося від попередніх? Висвітлення цих важливих питань дасть змогу зрозуміти, чому в 1648 р. «професійне військо» (за версією Н. Яковенко) на чолі з Б. Хмельницьким (до речі у тексті Програми навіть не згадується про те, що він був гетьманом Війська Запорозького) задумало повстати.

3) «Демократія як найкращий устрій держави і суспільства» (с. 20). В межах «європейського», а також «османського» та «китайського» світів (адже автор прагне до «увсесвітнення» шкільного курсу історіі) були й інші політико-філософські погляди на «демократію», які не визнавали ії за «найкращий устрій».

4) «Поява перших політичних партій, які ставили за мету зміну існуючого державного устрою революиійним шляхом» (стор. 20). Даний вислів автора дуже вже нагадує положення сумнозвісного «Короткого курсу ВКП (б)» авторства Й. Сталіна, який потім «плавно» перекочував в усі вузівські підручники «Історії КПРС». А чому $б$ не подати матеріал про «нереволюційні» партії? Чи таких не було? Чи в даному випадку детермінується російська революція 1917 року?

5) «Фізичне знищення інтелігенції, незгідної з комуністичними перетвореннями» (c. 21). Сприймається так: «комуністичні перетворення» були позитивними (перед тим йшлося про «розвиток промисловості», хоча якими загалом були ці «перетворення» не розкривається), а хто їх не сприймав, того «справедливо» карали! А чи мала ця інтелігенція «антропологічне обличчя»? Якою були ії «територіалізація» та етнічний склад? А чи не можна запропонувати вчителеві розповісти про повсякденне життя «гепеушника-енкаведиста», який «фізично знищував» якихось абстрактних (за поданням автора Програми) інтелігентів? Останніх лише знищували, тобто вбивали, чи висилали на Соловки, або ж до Сибіру? Чи усіх освітян, вчених, акторів, медиків, інженерів і т. д. репресували чи були й такі, що прислуговувалися або ж вірно й переконано служили режиму? Це питання чомусь замовчується;

6) «Примусове вивезення молоді на роботи до Німеччини» (с. 21). Так до Німеччини більшість молоді справді вивозили примусово, але також був певний 
добровільний рух. Якщо у Програмі декларується антропологічний підхід, то чому б не розповісти дітям про конретну особу (це можна зробити на основі ії спогадів, а отже використати інструментарій «усної історії»), яку примусово вивезли, але яка, наприклад, закохалася у свого господаря-німця, а потім навіть і одружилася 3 ним. Скільки було таких випадків? I чому близько 200000 «остарбайтерів» після 1945 р. залишилося на Заході? Це явище було особливим чи типовим? Чи не сприяв би такий приклад формуванню у дітей основ толерантності та політкоректності?;

7) «Визвольний украӥнський рух проти нацистів та Радянського Союзу» (с. 21). Якщо вже подано «нацисти», то 3 іншого боку мусять бути «комуністи» або «більшовики», а у випадку вживання назви «Радянський Союз», відповідно «Німеччина». А загалом у Другій світовій війні на боці гітлерівської Німеччини воювали не лише нацисти, тобто представники Націонал-Соціалістичної робітничої партії Німеччини, але й представники інших партій та безпартійні.

Не зрозуміло також, чому шкільні програми для 5 - 12 класів є «Програмами викладання історії України в школі», а Програма для 5-го класу є «Вступом до історї̈», а не до «історії України» (стор. 3, 15). Очевидно саме тому на українську історію 335 годин відводиться всього близько 16 годин, тобто менше половини від усього матеріалу!

Тепер щодо гучних заяв автора про «антропологізацію» програми «в центрі якої має бути людина»: протягом 35 уроків п’ятикласник має узнати лише про 17 (!) історичних осіб, а саме - «першого українського лікаря Агапіта», «князів Володимира Святославовича, Ярослава Мудрого і Данила Галицького» (ліхтарик) «книговидавця Івана Федорова» (ліхтарик), «Мартіна Лютера» (ліхтарик), «Юрія Дрогобича» (ліхтарик), «Гійома де Боплана» (ліхтарик), «князя Дмитра Байди-Вишневецького», «Богдана Хмельницького», «Івана Мазепу» (ліхтарик), «Шевченка» (ліхтарик), Шашкевича (ліхтарик), «Михайла Грушевського, Павла Скоропадського, Симона Петлюру (ліхтарик), «Михайла Горбачова» (ліхтарик). При цьому три особи не є представниками суто української історії, а про 14 осіб учні мають взнати не з основного матеріалу, а з текстів додаткових «ліхтариків».

Знову присутні одні «великі» і «видатні» - князі, гетьмани і президенти. Хоча, як бачимо, далеко не всі. А де ж представники «мовчазної більшості», де вихідці із декларованих у Концепції «конкретних соціальних груп» (стор. 11) - «дрібного шляхетства», «рядового козацтва», «заможнього селянства», «цехового міщанства» і т. ін. Де, врешті-решт жінки? Ні княгині Ольги, ні Анни Ярославни, ні Ганни Золотаренко, ні Олени Виговської, ні Ганни Скоропадської, ні Лесі Українки, ні Ліни Костенко? Але це знову ж таки «великі», а де «середні» та «менші» жінки?

Порівняємо такий підхід із відкинутою та розкритикованою пані Н. Яковенко попередньою і діючою сьогодні Програмою Міністерства освіти і науки України від 2005 р. (вид-тво «Перун»). Тут у межах тих самих 35 годин вчителі та учні можуть ознайомитися 3 діяльністю 16 осіб: Володимира, Ярослава Мудрого, Володимира Мономаха, Данила Романовича, Василя-Костянтина Острозького, Петра Конашевича-Сагайдачного, Богдана Хмельницького, Івана Мазепи, Павла Полуботка, Петра Калнишевського, Григорія Сковороди, Івана Котляревського, Тараса Шевченка, Івана Франка, Лесі Українки та Михайла Грушевського. Як бачимо, «антропологічні ряди» двох програм за окремими винятками майже нічим не відрізняються. То в чому полягає новаторство п. Н. Яковенко?

Основною метою «антропологізації» за задумкою автора $\epsilon$ відмова від надмірної мілітаризації, а також «обговорення політичних та військових подій здебільшого на прикладах поведінки конкретних соціальних груп», «оповіді про розмаїття поведінкових мотивацій різних політичних, соціальних чи локальних груп» (с. 11). I справді, з 35 годин лише 4 години безпосередньо відводяться військовій історії, при цьому дві години 
відводяться на «козацьку добу» XVI - середини XVII століття і дві години на 20 століття (Першу та Другу світові війни). Як діяв конкретний «антропологічний індивід» або ж конктертна «політична, соціальна чи локальна група» в межах Першої світової війни 1914 1918 pp., можна побачити 3 розпису відповідного уроку, що передбачає: «Виникнення великих держсв у Першій світовій війні. Труднощчі війни й наростання незадоволення діями правителів та урядів у краӥнах-учасницях війни. Революиії в Європі 1917 - 1918 років. Завершення війни, розпад Австрійської та Російської імперій $і$ поява на ӥхніх територіях нових держсав» (виділ. - Рец.). А тепер запитаємо автора Програми: чи знає вона хоча б одного рядового українця (а таких було десятки тисяч) - героя Першої світової війни, який був нагороджений російським царем чи австро-угорським імператором? Чи були серед генералітету та офіцерів тієї чи іншої воюючої армії вихідці 3 «підросійської» чи «підавстрійської» України? Чи представник якоїсь певної конкретної групи (наприклад, російського офіцерства або ж рядового складу) родом з Чернігівщини або Полтавщини відправляв листи до рідних і що він у них писав про війну та їі лихоліття? А скільки представників українського етносу/нації чи інших етносів, які населяли територію України (як військового так і «мирного») загинуло під час Першої Світової війни? I цього немає серед передбачуваних питань даного уроку. А як же тоді задекларовані у Концепції принципи висвітлення «лихоліття та фізичних й матеріальних втрат мирного населення»? На жаль, у Програмі майже не бачимо ні Людини як такої, ні наскрізної «повсякденної історії», ні «усної історії». А що ж є? Як бачимо, тільки голослівні «концептуальні» твердження та пропозиція викладати ту ж саму «владну історію», тобто минуле «держави/країни/імперії» та «правителів/урядів» як абстрактних політичних і владних сил.

«Людина є центром історії» (за Люсєном Февром). Погоджуємося, що для багатьох представників історичної науки це визначення може бути основоположним методологічним гаслом. Однак як таку антропологічну «аксіому» застосовувати в шкільній освіті? Адже дітям треба пояснити, що людську істоту все ж таки створив Бог. А як бути з тим, що люди об’єднуються в соціальні/антисоціальні групи, а також стани, етноси, нації тощо? А ці групи, стани, етноси, нації у свою чергу складають суспільство, займаються політикою, воюють між собою, організовують владні інституції, творять держави та ін.? Тоді у підлітка може виникнути закономірне питання: а хто ж тоді стоїть в «центрі історії» - Бог, Людина/Люди, Стан/и, Етнос/и, Нація/і, Військо/а, Суспільство/а, Влада/и, Держава/и? Очевидно що у даному випадку не потрібно відмовлятися від «теологічної», «національної», «соціальної», «владної» (або ж «політично-мілітарної» за визначенням Н. Яковенко) історій на користь лише «людиноцентричної» версії минулого. Найкращий вихід завжди простий поєднати усі ці визнані у світовій історіографії й дидактиці методологічні принципи осягнення минулого.

Тепер щодо декларованої у пропонованій Концепції «територіалізації», головним завданням якої є заміна видуманої самим же автором міфічної «політично-мілітарної історії» (адепти якої начебто творили попередні шкільні програми та підручники: див. с. 10 Концепції) на користь історії «етнічного багатоманіття» та «представлення історичної специфіки окремих регіонів України».

Запитаємо, що учні 5-го класу можуть взнати про пращурів сучасних росіян, білорусів, євреїв (згадано двічі: урок № 4, тема II; урок № 4 теми V), поляків, кримських татар (один раз: урок № 1, тема II), німців, молдаван, болгар, угорців, румунів, греків, вірменів (один раз: урок № 4, тема II), циган (ромів), грузин (один раз: урок № 4, тема II), гагаузів, татар, караїмів, ногайців, чехів, словаків, кримчаків, сербів та інші етноси, які населяли у різний час такі етнічні землі України як Запорожжя, Слобожанщина, Чернігово-Сіверщина, Новоросія, Кубань, Лівобережжя, Правобережжя та Західна Україна загалом, Галиччина, 
Поділля, Буковина, Волинь, Полісся, Закарпаття, Крим (Таврія), Холмщина, Підляшшя, Перемишльчина, Мармарощина, Берестейщина, Задунайщина, Буджак та ін.? Про переважну більшість із них (як ентосів, так і земель) немає жодної згадки або ж навіть натяку впродовж усіх 35 уроків. Лише під час одного (!?) уроку (урок № 1 теми IV) вчителеві пропонується розповісти дітям знову ж таки про якісь абстрактні «багато етносів», що входили до Австрійської, Російської та Османської імперій (с. 20). I знову «імперії», а де ж «регіони», «землі», «краї»? Ось так п. Н. Яковенко впроваджує собою ж задекларований територіальний принцип викладу матеріалу, тобто майже зовсім його не застосовує на практиці.

Викликає зауваження й запропонований принцип «соціального розчленування» історії України на «представлення суспільства як конгломерату груп» (а де ж поділася Людина?) й особливо запровадження такого підходу в $5-8$-х класах, адже в такому випадку учню пропонується вибирати: бути «своїм», «зрадником» чи «колаборантом»? Якщо у старших класах підліток/юнак можливо й зможе вибрати, хто був «правий» чи «винний» серед його пращурів, то у 10 - 14-річному віці дитина ще не може усвідомити на основі пропонованого «критичного аналізу» (?!) свого вибору.

Сьогодні фахівці з методики викладання історії наголошують на таких основних вимогах до програм з історії: 1) урахування часу, місця й педагогічної доцільності запровадження історичного поняття (дати, факту), виходячи зі структури історичного матеріалу, що вивчається, та вікових особливостей учнів; 2) логічне впорядкування у тексті підручника фактів і понять 3 урахуванням набутих учнями знань, умінь i навичок та програмового матеріалу, який вивчатиметься далі; 3) неодмінне пояснення нових і складних понять; 4) побудова методичного апарату таким чином, щоб учень отримував не готові рішення проблемних завдань, а спонукався до їх самостійного (під керівництвом учителя) пошуку; 6) яскравість викладу матеріалу, оскільки саме цей компонент часто слугує мотивацією до вивчення вітчизняної історії $[1$, с. 129 130]. На переконання більшості вчених-педагогів, для 5-го класу необхідно розкривати матеріал в емоційно-насичених образах та робити подачу матеріалу у вигляді Оповідей або ж Книги для Читання. Натомість п. Н. Яковенко, на наше глибоке переконання, пропонує педагогам викладати дітям скорочений та спрощений вузівський (!?) курс «Вступу до історії».

Історичні знання, отримані учнями 5-го класу, мають узагальнювати пропедевтичний (упроваджувальний) курс історії, специфіка якого за висновками педагогів та методистів полягає, по-перше, у розв'язанні на доступному для дітей рівні найважливіших проблем, які хвилюють людей (життя, смерть, любов, щастя, справедливість тощо) та розкритті історії більше на «побутовому», ніж на науковому рівні. Психологічні особливості (підвищена емоційність, імпульсивність i, як наслідок, нестійкість уваги), а також несформованість інтересів дають змогу вивчати дітям 10- 11річного віку лише епізодичний, тобто ознайомлювальний чи оглядовий курс історії, де вона подається як ряд хронологічно послідовних епізодів: описів історичних подій, життєписів історичних осіб, “образів” з повсякденного життя людей у минулому тощо. Цього також немає у пропонованій Програмі.

Чому б, наприклад, автору рецензованої Програми не скористатися апробованим методологічним підходом до тематичного розподілу навчального матеріалу для шкільного курсу історії Польщі, який викладається в 4 - 6-х класах початкової школи сусідньої слов'янської держави. Він планомірно розподіляється на такі тематичні блоки: 1) державний герб та державний гімн; 2) патріотичні пісні та патріотична історична література; 3) місцеві осередки національної пам'яті; 4) відомі поляки; 
5) особистість та спільнота; 6) участь школярів в управлінні; 7) самоврядування; 8) індивід, суспільство, нація, держава; 9) громадянські права та обов'язки; 10) норми суспільного життя - спільне благо - патріотизм [2, с. 33]. У зв'язку з цим видається доцільною пропозиція львівського педагога Р. Пастушенка про те, що в українській початковій школі потрібно було б вивчати в основному інформацію «про минуле рідного для дітей краю, населеного пункту (міста, села), подати легенди про місцеві історичні пам'ятки, біографії відомих людей, національних героїв, історію національних свят тощо: легенди, думи, уривки 3 літописів, спогадів та інших документів» [3, с. 103-107].

Натомість п. Н. Яковенко, на нашу думку, лише декларативно оголосила про те, що «український етнос є серцевинним стрижнем національної історії» (с. 10), а сама свідомо чи підсвідомо прагне, по-суті, деукраїнізації (а, отже, своєрідної глобалізації) свідомості майбутніх громадян України, яку й справді впродовж багатьох віків репрезентували й продовжують представляти різні етноси. Проте, принаймі 3 XVIII ст. українці як етнос становили від 75 до 90 \% від усього населення, а багато представників інших етносів/націй не соромилися захищати інтереси України та вважали себе «політичними українцями», які належали до «спільної батьківщини». Згадаймо Пилипа Орлика (чешсько-білоруського походження), Володимира Антоновича (польського), В'ячеслава Липинського (польського), Дмитра Донцова (російськкого), Наталію Полонську-Василенко (російського), Максима Рильського (польського), Миколу Бажана (єврейського), Олену Апанович (білоруського) та багатьох інших видатних i менш знаних особистостей. Адже саме у 5-му класі закладаються основи громадянського патріотизму, поваги до інших націй і держав. А коли власне «українське» (громадянське, політичне, етнічне, національне) у даному випадку намагаються замінити на принцип «етнічного багатоманіття» це виглядає як профанація певних методологічних концепцій та неодмінно веде до космополітичноглобального сприйняття свого минулого.

Хіба так можна виховати патріота Української (!) держави або ж «ідеального» члена громадянського суспільства України, хай то буде українець, росіянин, поляк, єврей, грек чи болгарин за етнічним походженням? У росіян $є$ своя держава, так само як і в поляків, євреїв, греків чи болгар, а програми шкільної освіти цих країн вирізняються надзвичайно великим патріотизмом саме до своєї Краӥни, свого Етносу, своєї Нації, своєї Мови, своєї Культури, своїх Традицій, своїх Символів і врешті-решт своєї Icторії. Та чи висвітлюється в шкільних підручниках Росії (або ж Польщі, Ізраїлю, Греції, Болгарії) внесок українців в історію їхніх держав чи суспільств? Питання, очевидно, поки що залишається риторичним.

Перевантаження навчальною інформацією, що притаманне рецензованій Програмі для 5-го класу, для більшості учнів стане важким та відчуженим у сприйнятті. Причина цього в намаганні автора механічно вмонтувати зміст шкільної історичної освіти до авторських (інколи надто контроверсійних) досягнень в сучасній історичній науці. Однак історія-дидактика, як відомо, $€$ засобом духовного, соціокультурного впливу на особистість, а історія-наука - засобом наукового дослідження минулого. Не кількість історичної інформації повинна стати пріоритетом програми викладання історії України, а засоби ії опрацювання на уроці.

На жаль, потрібно відзначити, що положення рецензованої Концепції історії України в школі (проект) та Програми для 5-го класу «Вступ до історії» (автор Н. Яковенко) не дотримуються повною мірою рекомендацій Ради Європи «Про викладання історії у XXI столітті в Свропі» (ухвалена Комітетом міністрів 31 жовтня 
2001 р. на 771-му засіданні). Звертаємо увагу й на те, що Програма для 5-го класу також не $\epsilon$ синхронізованою з методичними засадами викладання історії в школі та майже не враховує вікових особливостей учнів 10 та 11-річного віку. 3 метою виправлення перерахованих недоліків та зауважень дані авторські проекти потребують подальшого серйозного обговорення та експертної оцінки за участю провідних істориків (як науковців, так і викладачів), педагогів (як вчених, так і практиків), в т. ч. методистів, соціологів, психологів, задля їхньої кардинальної переробки.

Насамперед, нашим учням 5-го класу необхідно викладати історичний матеріал про минуле рідного для дітей краю, населеного пункту, розповідати легенди про місцеві історичні пам'ятки, біографії відомих людей, національних героїв, історію національних свят, вчити українські історичні пісні та думи, а також вивчати історію національної символіки. Виклад пропедевтичного історичного курсу в навчальних закладах України різнього рівня має відбуватися за допомогою спеціальної ігрової педагогічної методики та запровадження «живих уроків» - відвідування музеїв, парків, історичних місць свого міста, селища чи села. Тільки так ми зможемо виховати повноцінного громадянина.

\section{Джерела та література:}

1. Огнев'юк В. До питання про зміст історичної освіти / В. Огнев'юк // Концептуальні засади сучасної шкільної історичної освіти. Збірник документів і наукових праць. - Бердянськ, 2007. 2. Розенбаум С. Національні аспекти в сучасних польських навчальних програмах з історії / C. Розенбаум // Історична освіта: європейський та український досвід. Викладання національної історії в школах Центральної і Східної Свропи. - К., 2010.

3. Пастушенко Р. Концептуальні засади історичної освіти («круглий стіл» на сторінках журналу) / Р. Пастушенко // Історія України. - 1999. - №4. - С. 3-6.

\section{References:}

1. Ohneviuk, V., 2007. Do pytannia pro zmist istorychnoi osvity. Kontseptualni zasady suchasnoi shkilnoi istorychnoi osvity. Zbirnyk dokumentiv i naukovykh prats. Berdiansk. [in Ukrainian]

2. Rozenbaum, S., 2010. Natsionalni aspekty v suchasnykh polskykh navchalnykh prohramakh z istorii. Istorychna osvita: yevropeiskyi ta ukrainskyi dosvid. Vykladannia natsionalnoi istorii $v$ shkolakh Tsentralnoi i Skhidnoi Yevropy. Kyiv. [in Ukrainian]

3. Pastushenko, R., 1999. Kontseptualni zasady istorychnoi osvity («kruhlyi stil» na storinkakh zhurnalu). Istoriia Ukrainy, 4, pp. 3-6. [in Ukrainian]

Отримано: 01.12.2020 p. 
ISSN 2519-2523 (print)

Chornomors'ka mynuvshyna. - 2020. - No.15

DOI: $10.18524 / 2519-2523.2020 .15 .218688$

УДК 94(477) “2020”

\title{
HISTORIANS AND SCIENTIFIC-PRACTICAL CONFERENCE: MYTH OR REALITY (ON THE EXAMPLE OF SCIENTIFIC-PRACTICAL CONFERENCE "O.M. POL' IN HISTORY AND CITY MEMORY OF DNIPRO, 2020")
}

\author{
Svitlana Kaiuk \\ ORCID: https://orcid.org/0000-0002-2452-2642 \\ PhD (History), Associate Professor \\ Oles Honchar Dnipro National University \\ 72, Gagarina av., Dnipro, 49000, Ukraine \\ skaiuk22@gmail.com
}

The information report is dedicated to the scientific-practical conference held in Dnipro. Reports of the conference participants, the practical component, which is strengthened by the role of local authorities of Dnipro, the ability of historians to influence the formation of historical and cultural landscape of the city, historical memory, the need to change the conference model of behavior at conferences designed for representatives of various sciences and practice are analyzed. The personal responsibility of historians who seek to go beyond academic offices into public space and the possible dangers in the formation of new images of "heroes" are emphasized. The conference is dedicated to the results of the search for the burial place and grave of a prominent man in the history of the Dnipro - Alexander Pol'. Church of St. Lazarus, near which in the late XIX century Pol' was buried, was destroyed by Soviet authorities, the burial place was considered inaccessible for research. The interest of the community, local bloggers, caring historians, financial and organizational support of the mayor of Dnipro allowed to adjust the location of the burial place. Archaeological and anthropological studies have confirmed this. The architects designed a new project of the pantheon of memory, and city officials began to implement a project for a new Sevastopol Park.

Key words: historical memory, public history, scientific-practical conference, O.M. Pol', the image of the city.

\section{Світлана Каюк}

ORCID: https://orcid.org/0000-0002-2452-2642

Кандидат історичних наук, доцент Дніпровський національний університет імені Олеся Гончара

Пр. Гагаріна, 72, Дніпро, 49000, Україна skaiuk22@gmail.com

\section{ІСТОРИКИ ТА НАУКОВО-ПРАКТИЧНА КОНФЕРЕНЦІЯ: МІФ ЧИ РЕАЛЬНІСТТЬ (НА ПРИКЛАДІ НАУКОВО-ПРАКТИЧНОЇ КОНФЕРЕНЦЇ̈ «О. М. ПОЛЬ В ІСТОРЇ̈ ТА МІСЬКІЙ ПАМ'ЯТІ ДНІПРА», 06 ЖОВТНЯ 2020 р., ДНІПРО)}

Інформачійне повідомлення присвячене науково-практичній конференції, щуо відбулася у Дніпрі. Аналізуються доповіді учасників конференції, практична складова, яка посилена роллю місиевої влади Дніпра, можливості істориків впливати на формування історикокультурного ландшафту міста, історичної пам'яті, необхідність зміни конферениійної 
моделі поведінки на конференціях, які розраховані на участь представників різних галузей науки та практики. Підкреслюється особиста відповідальність істориків, які прагнуть вийти за межі академічних кабінетів у публічний простір та можливі небезпеки при формуванні нових образів «героїв».

Ключові слова: історична пам'ять, публічна історія, науково-практична конференція, О.М. Поль, образ міста.

«Якщо ви думаєте, що пригоди небезпечні, спробуйте рутину - це смертельно...»

(П. Коельо)

Конференція як форма організації наукової діяльності, можливість обговорення досягнень, обмін думками $\epsilon$ необхідною та обов'язковою як ковток повітря компонентою життя для тих, хто вважає себе науковцем. Не існує наукових звітів, в яких не було б відповідної графи, яка обчислює відповідне ККД наукової діяльності через конференції. Різновидів конференцій безліч, як і похідних від неї (семінарів, симпозіумів тощо). Науково-практична конференція - один із таких різновидів, яких в академічному просторі незчисленна кількість. Здавалося б, це один із найбільш зрозумілих видів почесного зібрання, адже воно орієнтоване на значимість практичних результатів. I якщо 3 представниками технічних наук все зрозуміло, результат їхньої наукової діяльності відразу може бути скерований на практику, то 3 гуманітаріями складніше. Результат як уточнення наукової тези мало зрозумілий громадськості. Питання на кшталт «а чи має науковий продукт бути цікавий громадськості» у даному випадку не дискутується (практична складова підкреслена назвою), так само, як і філософські роздуми, про те, чи повинна академічна наука виходити у публічний простір. Відповідь на останнє питання кожен науковець вирішує самостійно і часто безапеляційно вважає свою точку зору єдино вірною. Однак науково-практичний жанр передбачає вихід на більш широку публіку, що відразу наражає на небезпеку. Публічну складову бажано підсилити висвітленням у 3MI, отже виникає небезпека викривлення інформації. Для журналістів та публіки певні неточності мало зрозумілі, професіоналів відразу скорчить, а колеги по цеху із задоволенням накинуться 3 критикою. Широкий резонанс тут же активізує увагу шанувальників справи, краєзнавців, істориків за освітою (на лихо, підсиленою дипломами кандидатів, а то й докторів наук) та за покликом душі, які «ну точно все знають» і коригувати свої знання не збираються. Їхня думка у публічному просторі часто може навіть переважати, бо за правилом, це не ледачі люди з відповідною «активною життєвою позицією». Отже, виникає наступне питання: а чи варто витрачати на це зусилля? Відповідь має бути підсилена назвою конференції, адже $є$ необхідність колегіально підтвердити практичний результат та зафіксувати це резолюцією.

У жовтні 2020 р. у Дніпрі відбулася саме така науково-практична конференція, яка ідеально відповідає жанру. I навіть участь академічної спільноти справу не зіпсувала. Олександр Миколайович Поль - знакова постать міста та регіону. Подібні імена (хоча для дніпрян він $є$ виключним і майже геніальним, «степовим Колумбом», який «відкрив Каліфорнію») «героїв», які зробили місто, край таким, яким він $\epsilon$, можна бачити і в інших місцях. Їх можна віднести до категорії відомих. Але ідеологічні, а слідом за ними й історіографічні хитання забезпечують тривале забуття, потім поступове пригадування, яке може вийти за межі академічного простору на вулиці міста, а може лишитися зрозумілим та очевидним для «обраних» (у даному випадку істориків). Суспільна впізнаваність «героя» залежить або від наполегливості та небайдужості істориків (і в даному випадку шанувальники та фахівці за покликом 
душі можуть значно допомогти, варто лише скоординувати та зорганізувати їхні зусилля), або від дій місцевої влади та чиновників. Останнє в українських реаліях та умовах постійної кризи (економічної, фінансової і не тільки...) є для гуманітаріїв мрією умовно не здійсненою. Однак у Дніпрі такі «марева» (особливо для тих істориків, які дослідженню О.М. Поля та його епохи присвятили значну частину наукового життя) виявилися неочікувано реальними.

Конференція підвела підсумок тривалої наукової діяльності істориків кількох поколінь (Г. Швидько, В. Лазебник, І. Кочергин, В. Старостін, М. Кавун, Т. Портнова - більшість виступила 3 доповідями) та поєднала їх із зусиллями влади у меморіалізації імені О. М. Поля. Роль постаті О. М. Поля у визначенні пріоритетів діяльності мера міста Б. А. Філатова та його оточення, бізнесового олімпу, керівників різного рівня та структур ще доведеться з'ясувати. Очевидно лише, що такому неочікуваному розмаху сприяла не тільки реформа децентралізації з усіма наслідками, але й рідкісний збіг: Б. А. Філатов - історик за освітою, кандидат юридичних наук, журналіст, бізнесмен та практик, який звик доводити справи (навіть дуже ризиковані) до кінця. Витрачати чималі гроші на гуманітарні проекти під час війни, пандемії, знов кризи, виборчих перегонів - випробування не 3 легких. Значної кількості голосів зазвичай такі проекти не додають. Але в даному випадку, сподіваємося, вийшло і це.

Заручившись підтримкою наукової громадськості міста, конференція передусім мала підсумувати результат практичної діяльності людей з абсолютно різних галузей. Черговий спалах зацікавленості постаттю О.М. Поля спровокував місцевий блогер, молодий шанувальник історії рідного міста А. М. Костюк (його виступ на конференції викликав значний інтерес), який навесні 2019 р. віднайшов у інтернет-мережі новий, раніше невідомий аерофотознімок Люфтваффе червня 1944 р., звернувся до міської влади 3 проханням купити його, синхронізував із сучасною картою міста та зрозумів, що він може значно скоригувати «беззаперечно» відомі історикам факти. Передусім мова йшла про розташування Лазаревської церкви, біля якої свого часу був похований почесний громадянин міста О. М. Поль, але яку рішенням радянської влади було підірвано у 1950ті pp., а всі поховання знесені. На місці цвинтаря за радянськими канонами було побудовано Севастопольський парк із: розважальним майданчиком для дітей, пивбаром, танцювальним майданчиком та естрадою. На «переконливу» думку місцевих істориків та краєзнавців залишки церкви стали основою насипу курганного типу, на якому тоді ж було збудовано меморіал на честь незрозумілих «перемог» Росії у Кримській війні та вшанування пам'яті загиблих (поруч знаходиться відома лікарня ім. I. Мечникова, яка під час війни дійсно лікувала поранених, а померлих ховали на Севастопольському цвинтарі). Меморіал занесено до реєстру пам'яток - отже чіпати не можна. Відтак могила О. М. Поля, яка розташовувалася біля церкви, вважалася втраченою назавжди. Комп'ютерна синхронізація, виконана А.М. Костюком, переконливо доводила інше: Лазаревська церква знаходилася на кілька десятків метрів правіше від кургану, отже археологічні дослідження можливі. Наполегливість блогера та здатність влади на неформальні рішення (які інколи можуть здатися божевільними) змусили діяти.

Археологічні дослідження - необхідна складова діяльності тих керівників господарських об'єктів, які займаються будівництвом. Це зрозуміла річ. Малозрозумілим для громадськості, та й деяких фахових істориків, $є$ фінансування археологічних розкопок за рахунок місцевого бюджету. У Дніпрі вже кілька років працює власна Дніпровська археологічна експедиція, яку очолює кандидат історичних наук, доцент, старший науковий співробітник ДП «НДЦ «Охоронна археологічна служба України» Інституту археології НАН України Д. Л. Тесленко. 
Замовником та організатором археологічних досліджень, а також координатором зусиль щодо популяризації відповідної діяльності у ЗМІ, піар-кампанії на честь О. М. Поля (із амбітною метою, яка, маємо надію, змінить сірий радянський історикокультурний ландшафт міста та призведе до створення нового його образу в очах містян) стало комунальне підприємство міської ради «Етнографічні парки Дніпра» в особі директора Д. Г. Каюка (кандидат історичних наук, доцент). Отже, від самого початку було скоординовано зусилля громадських активістів, влади, чиновників, які вміють реалізовувати конкретні проекти та істориків. Д. Г. Каюк повідомив на конференції про всі ті випробування, передусім організаційного, бюрократичного характеру, що випали на долю дослідників під час пошуків руїн церкви та могили О. М. Поля й заходи, які вживалися для ідентифікації знайдених людських останків. Д. Л. Тесленко у своїй доповіді закцентував увагу на археологічних дослідженнях Лазаревського церковно-меморіального комплексу, проведених у Севастопольському парку влітку 2020 р. Технічна (а відтак і практична) переконливість можливості проведення археологічних розкопок на момент їх планування була підсилена доповіддю С. М. Веретюка (керівник Noodohere Engineering School) про результати пошуку фундаменту церкви з допомогою геолокатора.

Найбільший інтерес для представників ЗМІ викликала доповідь О. Д. Козак (кандидат історичних наук, старший науковий співробітник відділу біоархеології Інституту археології НАНУ) «Антропологічна ідентифікація останків 3 поховання кінця XIX ст. зі склепу № 2», яка переконливо довела, що саме ці останки належать О. М. Полю (а не зі склепу № 1, як спочатку вважали археологи). Результати антропологічного аналізу, порівнянням 3 фотодокументами, дослідженнями істориків щодо специфічної діяльності та образу життя О.М. Поля дозволили зробити висновки переконливими.

Практичну складову конференції підсилила участь міського голови м. Дніпра, який вручив подяки всім причетним, починаючи від тих істориків, які досліджували життя та діяльність О. М. Поля ще за часів радянської влади (а це було не те що ризиковано, але не канонічно), розшукали будинок, в якому він проживав і який на диво зберігся (доповідь В.ІІ. Лазебник, завідувачки відділу наукових досліджень історії України та краю Дніпропетровського національного історичного музею ім. Д. І. Яворницького), популяризували його та робили відомими й закінчуючи тими, хто проводив археологічні розкопки й експертизи. До речі, міській владі, попри значні зусилля, ще не вдалося повернути будинок О. М. Поля у власність громади (на сьогодні він $є$ приватною власністю швейцарської компанії «GCONNECT AG»). Міський голова Б. А. Філатов звернувся до фахівців із проханням допомогти у формуванні історичної пам'яті міста, а відтак сприяти зміні його образу в очах як мешканців, так і гостей, журналістів тощо. Практичні висновки відразу мали робити директор департаменту парків та рекреацій Дніпровської міської ради О. В. Буйволюк та директор КП «Дирекція територій і об'єктів рекреацій» О. С. Давиденко, а слідкувати за доцільністю та можливістю майбутніх змін Севастопольського парку згідно з законодавчими нормами щодо природно-охоронної зони Н. Ю. Лиштва (начальник управління з питань культурної спадщини Дніпровської міської ради). А те, що плани щодо переформатування історико-культурного ландшафту м. Дніпро, що якісно прикрасять місто та скоригують історичну пам'ять_широкого кола містян, можуть бути реалізовані на практиці стало зрозумілим після доповіді архітектора, члена НСАУ О. А. Іваницької «Музеєфікація розкопів, артоб'єкти - сучасні рішення благоустрою відповідно до законодавства та кліматичної стратегії міста». В такий 
спосіб учасникам конференції був представлений проект реконструкції Севастопольського парку 3 урахуванням побажань істориків та спрямований на створення нового соціо-культурного ландшафту міста, якісно нових місць відпочинку, які ненав'язливо можуть слугувати основою для побудови нової історичної та публічної культури містян. Майбутній пантеон славетних містян Дніпра може бути не тільки місцем вшанування, але й майданчиком для проведення культурних заходів на відкритому просторі. Доповідь О. I. Бондаренко (старший викладач Придніпровської державної академії будівництва та архітектури) підкреслила давні прагнення архітектурної еліти міста щодо реконструкції Севастопольського парку з відновленням церкви Святого Лазаря.

Таке нестандартне поєднання вузьких фахівців із абсолютно різних галузей з метою вирішення конкретних завдань: засвідчити достовірність віднайдених останків як таких, що дійсно належать О. М. Полю, та максимально широко продумати шляхи та доцільність меморіалізації, створення чи нестворення «образу героя», можливі небезпеки формування колективної пам'яті тощо - змусили професійних істориків дещо змінити модель звичайної поведінки на наукових історичних конференціях. Їхні доповіді мали бути зрозумілі абсолютно всім присутнім, отже слід було значно скоригувати термінологічний апарат та лексику. Присутність колег по цеху змушувала робити це максимально коректно та убезпечувала від примітивізації. Це виявилося можливим та практично необхідним. Історик, який виходить 3 кабінету у межі публічного простору, має тонко відчувати лексичну межу дозволеного (багато синонімів, термінів, так звана «науковість» та химерність недоречні; під час таких зібрань стає зрозумілим, що надмірне використання подібних слів та виразів не підкреслює «розумність» доповідача, а насправді часто приховує відсутність думки як такої). Публічний простір та можливість впливати на суспільні процеси змушує істориків більше думати над тим, до чого не звикли кабінетні фахівці, - відповідальність. Практична реалізація задуманого, тісна координація із представниками ЗМІ (а така була під час усієї кампанії пошуків могили О. М. Поля через істориків-практиків, які не лінувалися готувати матеріали для прес-служби міської ради), а відтак можливість впливати на формування історичної пам'яті, змушують постійно думати про власну відповідальність. Наявність титулованих «весільних генералів» на такій конференції не приймуть, а навіть якщо їхня присутність буде необхідна згідно 3 протоколом, їм доведеться бути максимально короткими у виступах. Отже, справжня науково-практична конференція значно коригує конференційну поведінку науковців.

Відповідальність публічних істориків та необхідність глибокого думання над популяризацією «героїв» підкреслили дискусійні доповіді кандидатки історичних наук, доцентки Дніпровського національного університету ім. Олеся Гончара Т. В. Портнової «ІІторична постать як візитівка міста: сучасний досвід» та кандидата історичних наук, доцента, директора КП «Етнографічні парки Дніпра» Д.Г. Каюка «У пошуках героя: Дніпро й міфологеми О. Поля». Доповідь доктора історичних наук, доцента Дніпровської «Політехніки», начальника відділу Українського інституту національної пам'яті I. С. Кочергіна «Міфотворчість як зворотній бік популярності: Олександр Поль в сучасних дослідженнях» стала відповіддю на пасквільні писання «колег по цеху», без яких за умови такої потужної кампанії, ясна річ, не обійшлося (мова йде про публікації В. Заруби на порталі Historians, які насправді на наукову критику навіть не заслуговують). Знаковість постаті О. М. Поля у контексті проблеми історичної пам'яті підкреслив доктор історичних наук, професор, декан історичного факультету Дніпровського національного університету ім. Олеся Гончара С. І. Світленко. 
Роздуми над теорією та практикою науково-практичних конференцій можна продовжувати до безкінечності, як й інформаційне повідомлення про дану конференцію, що була присвячена О. М. Полю. Очевидно лише, що рівень практичності конференції залежить від іï замовника та організатора, а історики, які будуть доречні для виконання практичних завдань, знайдуться. Практичний результат конференції $\epsilon$ ще й в іншому. На історико-культурницькій мапі України неочікувано з'являється Місто, мешканці якого поступово починають цікавитися своєю історією (і сприймати іiі саме як свою), люблять його та пишаються ним, розповідають Його історії (вигадані та реальні). До сих пір такими були Львів та Одеса, це надавало колориту та приваблювало туристів. Дніпро з'являється неочікувано, але достатньо швидко (підтримка та фінансування міської влади, особиста зацікавленість мера-історика дозволяють сподіватися на тривале співробітництво та практичний результат). В такий спосіб сучасне місто та його очільник (підсвідомо чи ні?) продовжують традиції О. М. Поля - лишати пам'ять про себе! I це не тільки нові вулиці, площі, мости та модерні засоби сполучення, як було за часів залізної лихоманки і є тепер. Мають бути нові логістичні відкриття, які свого часу зробив О. М. Поль і на які тепер сподіваються мешканці міста - міста, якому ще кілька років тому обіцяли долю Детройта.

Однак О.М. Поль відомий не тільки своїми підприємницькими та логістичними проектами, реалізацією фантастичних викликів, а й тими «божевільними» захопленнями, завдяки яким його пам'ятали навіть за радянських часів - колекцією старовини, що стала основою для відкриття музею, який довгий час носив його ім'я. А ще увагою до освітніх установ, попечителем та благодійником яких він був. Катеринослав часів залізної лихоманки був відомий своїми технічними (так званими реальними) освітніми закладами. Чи зуміє теперішній Дніпро відновити і цей потенціал? А чи можливо, дозволить собі більше - розкіш у вигляді якісної гуманітарної освіти? Очевидно, що дніпровські історики зуміли достойно відповісти на нетипові запити влади, а науково-практичні конференція це підкреслила.

Отримано: 02.12.2020 p. 
ISSN 2519-2523 (print)

Chornomors'ka mynuvshyna. - 2020. - No.15

DOI: $10.18524 / 2519-2523.2020 .15 .218689$

УДК 94:061.2(477.74)“"2005/2020”

\title{
BLACK SEA GAYDAMACK UNITY: 15 YEARS OF ACTIVITY
}

\author{
Uliana Hromovych \\ ORSID: https://orcid.org/0000-0001-6961-4906 \\ Master of history \\ Chief Specialist of Southern interregional department \\ Ukrainian Institute of National Remembrance \\ 26, Staroportofranktsivska Str., Odesa, 65020, Ukraine \\ gromovicula@gmail.com
}

The article offers information on the activities of the Black sea Gaydamack Unity for 15 years (2005-2020). The purpose, tasks and management of the society are defined. The information on measures on environmental protection, research and educational work with youth in the field of national-patriotic education is given.

Key words: modern Cossacks, Odesa region, Cossack society, Black Sea Gaydamack Unity

\section{ЧОРНОМОРСЬКЕ ГАЙДАМАЦЬКЕ З'ЄДНАННЯ: 15 РОКІВ ДІЯЛЬНОСТІ}

\author{
Уляна Громович \\ Магістр історії, головний спеціаліст \\ Південного міжрегіонального відділу \\ Українського Інституту національної пам’яті \\ Старопортофранківська, 26, Одеса, 65020 \\ gromovicula@gmail.com
}

У статті пропонується інформачія про діяльність Чорноморського Гайдамацького 3'єднання протягом 15 років (2005-2020). Визначено мету, завдання та керівний склад товариства. Подано інформацію про заходи щуодо охорони довкілля, науково-дослідну та виховну роботу з молоддю у сфері національно-патріотичного виховання.

Ключові слова: сучасне козаџтво, Одещина, козаџьке товариство, Чорноморське Гайдамацьке 3'єднання.

Українське козацтво - феноменальне явище світової історії. Південь України має глибокий і тісний зв'язок з українським козацтвом. І сьогодні в умовах незалежної України твориться сучасне українське козацтво, що являє собою систему самодіяльних об'єднань громадян України, мета яких - відродження традиційних козацьких цінностей. Воно відіграє важливу роль в політичному і культурному житті, разом з усім народом будує Українську суверенну державу.

Протягом останніх років становлення та розвитку сучасного козацтва на території Одеської області виникло чимало козацьких товариств. Одним із них $є$ громадська організація “Чорноморське Гайдамацьке 3'єднання”, що об'єднує навколо української національної ідеї тих, кому не байдуже минуле, сьогодення та майбутнє Батьківщини. 
Чорноморське Гайдамацьке 3'єднання (ЧГЗ) створене у 2005 р. Основні мета і завдання товариства - об'єднання зусиль українських патріотів в Одесі для:

- культурницької та історичної пропаганди української ідеї на Півдні України (дослідницький напрямок);

- наслідування дбайливого ставлення козацтва до навколишнього середовища (природоохоронний напрямок);

- охорони громадського порядку (правоохоронний напрямок);

- підготовки національно свідомої молоді (молодіжний напрямок);

- відродження традицій українського козацтва у сфері кінного спорту (кінноспортивний напрямок) [1, с. 208-209].

До керівного складу товариства входять: отаман Чорноморського Гайдамацького 3'єднання - Сергій Гуцалюк, історик, ветеран АТО, начальник Південного міжрегіонального відділу Українського інституту національної пам'яті; наказний отаман Чорноморського Гайдамацького 3'єднання - Олександр Голопотелюк, економіст, ветеран АТО, представник Одещини в Раді ветеранів України при Міністерстві у справах ветеранів України. Кількість членів ГО «Чорноморське Гайдамацьке 3'єднання» становить близько 200 осіб.

Гайдамаки співпрацюють 3 представниками громадських організацій i державних установ Одеси та Одеської області. Серед них особливе місце займає спільна робота 3 державним управлінням охорони довкілля в Одеській області, державною екологічною інспекцією з охорони довкілля північно-західного регіону Чорного моря, Одеським національним університетом імені I. І. Мечникова, відділом історії козацтва на Півдні України НДІ історії козацтва Національної академії наук України, з органами місцевого самоврядування.

Чорноморське Гайдамацьке 3'єднання має свій сайт: http://www.gaidamaky.od.ua/ та сторінку у соціальній мережі Facebook: @gaidamaky.od.ua, де постійно оновлюється інформація про роботу товариства. Діяльність Чорноморського Гайдамацького 3'єднання систематично висвітлюють одеські міські, регіональні та всеукраїнські 3МI.

В ЧГЗ функціонує екологічний підрозділ (керівник - Олексій Токмаков), який постійно здійснює рейди по Одеській області з охорони навколишнього середовища, серед яких: відстоювання території заповідного козацького дубу «Чорна ніч» у центрі Одеси, боротьба з браконьєрством на водах Тилігульського та Хаджибейського лиманів, участь у роботі міністерської комісії на Дністрі, виявлення незаконних смітників і шкідливих відходів переробки, затримання браконьєрів спільно 3 районними єгерями, виявлення фактів незаконної вирубки лісосмуг та багато іншого [2, с.190]. Чорноморські гайдамаки постійно разом 3 містянами беруть участь в суботниках на території Міського саду.

Науково-дослідний підрозділ Чорноморського Гайдамацького ’єднання (керівник - Володимир Полторак) проводить заходи зі збереження пам“яток козацької історії на території міста. Захищає від руйнування та постійно впорядковує разом 3 громадкістю Одеси два унікальних кладовища - Усатівське та Куяльницьке - 3 численними козацькими похованнями, найстаріші 3 яких датуються кінцем XVIII століття [2, с. 191]. Ці кладовища були визнані пам“ятниками історії та культури місцевого значення.

Козаками-гайдамаками також було встановлено пам'ятний хрест (2005р.) для вшанування подвигу загону запорозьких козаків на чолі з отаманом Семеном Палієм, 
який наприкінці березня 1691 року розгромив татарське військо, відпустив невільників і арештував цінних “язиків”.

Протягом 2006 - 2007 pр. науковцями Відділу історії козацтва на Півдні України на чолі $з$ доктором історичних наук, керівником Відділу Оленою Бачинською та козаками Чорноморського Гайдамацького 3'єднання було проведено пошукову роботу 3 виявлення та опису намогильних кам'яних хрестів, які вважаються козацькими у 9-ти селах Комінтернівського р-ну Одеської області: Петрівці, Каїрах, Калинівці, Широкому, Кордоні, Ранжевому, Любополі, Кошарах і Сичавці [1, с. 211]. У результаті дослідження було виявлено понад триста п'ятидесят надмогильних пам'ятників, які датуються кінцем XVIII - серединою XX ст.

Гайдамаки науково-дослідного підрозділу беруть активну участь в роботі всеукраїнських, регіональних та міжнародних наукових конференціях 3 козацької тематики. У 2019 р. представники ЧГЗ долучилися до проведення на березі Куяльницького лиману, в селі Корсунці першого великого етнофестивалю “Чумацький шлях. Сіль”.

32007 р. у рамках ЧГЗ діє молодіжний курінь (МК). Представники ЧГЗ проводять зустрічі з викладачами одеських ВНЗ та шкіл щодо співпраці та спільних заходів зі школярами та молоддю. Перше таборування відбулось на березі Тилігульського лиману Комінтернівського р-ну Одеської області - навчальний табір “Тилігульська Січ - 2007” [2, с. 190]. Козацький вишкіл пройшли два десятки козаків та козачок віком від 8 до 25 років. У своїй діяльності молодіжний курінь ЧГЗ плідно співпрацює зі спортивним козацьким клубом "Пластун-Характерник”, козаки якого займаються козацькими бойовими мистецтвами. А також співпраця проводиться 3 національною скаутською організацією України «Пласт: Одеса», культурнонаціональними організаціями та ін.

Козаки підрозділу співпрацюють з кінним клубом «Кубанка» (керівник - Марина Дрига) i безкоштовно навчають дітей с. Фонтанка верховій їзді та основам вольтижування i джигітування. Також члени товариства постійно проводять на запрошення директорів шкіл лекції для школярів з історії України про виникнення та формування українського козацтва, про козацькі походи та визначні битви, про історію українського війська та інше.

Козаки ЧГЗ беруть активну учать в організації та проведенні Всеукраїнської дитячо-юнацької військово-патріотичної гри «Сокіл» («Джура») серед команд учнів закладів загальної середньої освіти Одеської області. Мета якої полягає у вихованні юних патріотів України на основі національної гідності, високої самосвідомості та активної громадянської позиції, здорового способу життя духовно багатої та фізично розвиненої особистості. Члени товариства входять до складу суддівської колегії, таборової старшини та осавульської служби гри «Сокіл» ( «Джура»).

У квітні-травні 2020 р. Чорноморський науково-методичний ресурсний центр (структурний підрозділ ГО «Чорноморське Гайдамацьке 3’єднання», керівник - Зоя Дмитрук) організував в онлайн-форматі Одеську обласну школу виховників джур 3 метою підвищення методичного та практичного рівнів професійної компетентності фахівців 3 національно-патріотичного виховання (педагогічних працівників, громадських діячів, волонтерів). Чорноморський науково-методичний ресурсний центр розробив Освітню регіональну програму 3 організації та проведення підвищення кваліфікації фахівців 3 національно-патріотичного виховання, як методичне підгрунтя для проведення заходів Одеської обласної школи виховників джур, а для проведення семінарів, тренінгів, інших заходів [3, с. 1]. 
До складу Чорноморського Гайдамацького 3'єднання входять близько 40 учасників сучасної російсько-української війни на сході України, тому одним із важливих напрямків $є$ підтримка ветеранського руху. У 2019 р. представниками ЧГЗ створено ГО «Veterans Hub Odesa» (керівник - Олександр Голопотелюк) з метою допомогти участникам АТО, ветеранам, надати їм корисну інформацію щодо їхніх прав та можливостей згідно з діючими законами.

У вересні 2020 р. Чорноморське Гайдамацьке 3'єднання відзначило своє 15-річчя. В урочистих заходах взяли участь гайдамаки, друзі організації, представники духовенства, вчені-історики та військовослужбовці. Керівники 3'єднання нагородили козацькими хрестами всіх, хто пройшов 15-річний шлях організації разом, та тих, хто приєднався за цей час до спільної справи.

Одеське козацтво активно розвиває свою діяльність у різних галузях суспільного життя і це радує. Досвід діяльності Чорноморського Гайдамацького 3'єднання може стати корисним для інших козацьких товариств в Україні, що в свою чергу буде сприяти якісному підвищенню значення і ролі сучасного Українського козацтва, яке «вдень і вночі, і на суші, на воді - на захисті України!».

Бажаємо успіху козакам Чорноморського Гайдамаџького 3'єднання, їх гідній $i$ важливій для нашого народу справі!

\section{Джерела та література:}

1. Одеса козацька: наукові нариси. 2-е вид., випр. і доп. / О. А. Бачинська, Т. Г. Гончарук, С. Б.Гуцалюк, В. І. Кіров, А. І. Мисечко, Л. В. Новікова, В. М. Полторак. - Одеса : Феникс, 2008. $-239 \mathrm{c}$.

2. Гуцалюк С. Одеські гайдамаки у 2006-2007 pp. / С. Гуцалюк, В. Кіров // Чорноморська минувшина. - 2007. - Вип. 2. - С.189-192.

3. Освітня регіональна програма організації та проведення підвищення кваліфікації фахівців 3 національно-патріотичного виховання (педагогічних працівників, громадських діячів, волонтерів) [Електронний ресурс] // Чорноморський науково-методичний ресурсний центр ГО «Чорноморське гайдамацьке з’єднання» (упорядник програми Дмитрук 3. А.). - Одеса. 12 c. - Режим доступа: https://bit.ly/2Wuc5kV (дата 01.12.2020). - Назва з екрану.

\section{References:}

1. Odesa kozatska: naukovi narysy, 2008. 2nd edn. Odesa: Feniks. [in Ukrainian].

2. Gutsalyuk, S. \& Kirov, V., 2007. Odessa Haidamaks in 2006-2007. Chornomorska mynuvshyna, 2, pp.189-192. [in Ukrainian].

3. Osvitnia rehionalna prohrama orhanizatsii ta provedennia pidvyshchennia kvalifikatsii fakhivtsiv z natsionalno-patriotychnoho vykhovannia (pedahohichnykh pratsivnykiv, hromadskykh diiachiv, volonteriv). Chornomorskyi naukovo-metodychnyi resursnyi tsentr HO «Chornomorske haidamatske ziednannia» (uporiadnyk prohramy Dmytruk Z. A.). [online]. Odesa. Available at: $<$ https://bit.ly/2Wuc5kV> [Accessed 01 December 2020]. [in Ukrainian].

Отримано: 05.12.2020 p. 


\section{MICT}

\section{CTATTI}

\section{Станіславський В'ячеслав}

Повернення Кам’янця-Подільського під польську владу в 1699 р.: реакції

в Кримському ханаті та Туреччині. 3

Середа Олександр

Аджидере / Хаджидере: до питання османської назви селища Овідіополь .............. 10 Діанова Наталя

Історія розбудови Одеського храму Казанської ікони Божої Матері 17

Полторак Володимир

Навернення на іслам серед емігрантів з України у середині XIX століття:

випадок Михайла Чайковського (Мехмеда Садик-паші). 25

Юраш Свгеній

Статистичні звіти Одеського Піклувального комітету про в'язниці, як історине

Джерело

\section{Сорокіна Ксенія}

Петро Сокальський як діяч Імператорського Товариства сільського господарства Південної Росії (1869-1871)

Коробчук Анна

Газета “Одесский вестник” (1827-1894) як історичне джерело з історії

Одеського інституту шляхетних дівчат

Герасименко Вікторія

Міські голови Одеси на тлі революційних подій 1905 року 54

Музичко Олександр

Володимир Мошинський в українському козацькому русі XX століття 62

Бодруг Анатолій

Соціокультурна місія канадського Центру української культури та освіти «Осередок» (друга чверть XX - початок XXI ст.)

КОЗАКОЗНАВЧІ СТУДІЇ

Гречило Андрій

Микола Битинський та його робота над символами “Козакії"

Новікова Людмила

Презентації історії Правобережної та Лівобережної України в модерних регіонально-історичних текстах: до постановки проблеми.

Ложешник Олександр

Чорноморське козацьке військо в межиріччі Південного Бугу та Дністра: історіографія питання 100

\section{ПУБЛІКАЦІЯ ДОКУМЕНТІВ}

\section{Бачинська Олена}

Злочини, покарання та їх виконання у станицях Дунайського (Новоросійського) козацького війська (1828-1868 рр.): справа козака Івана Дульдієра

\section{Гончарук Тарас}

Листи до одесита Михайла Комарова з Петербургу, Москви, Кубані та інших регіонів Російської імперії поза межами України, як прояв консолідації національного руху на зламі XIX та XX ст. 


\section{Дубна Максим}

Діяльність «Уповноваженого у справах Російської православної церкви та релігігійних культів при Раді народних комісарів УРСР по Одеській області в 1944-1965 роках» (за матеріалами Державного архіву Одеської області)

\section{Чухліб Тарас}

\section{РЕЦЕНЗІї, ІНФОРМАЦИЯ}

Яку історію повинні вчити діти у 5-му класі:

до проблеми української пропедевтики

\section{Каюк Світлана}

Історики та науково-практична конференція: міф чи реальність (на прикладі науковопрактичної конференції «О. М. Поль в історії та міській пам’яті Дніпра», 06 жовтня 2020 р., Дніпро)

Громович Уляна

Чорноморське Гайдамацьке 3’єднання: 15 років діяльності 155

3мicm 159 


\section{CONTENTS}

ARTICLES

\section{Stanislavskyj Vyacheslav}

The return of Kamianets-Podilskyi under the polish power in 1699: reactions

in the Crimean khanate and Turkey ... 3

Sereda Oleksandr

Adzhidere / Hadzhidere: to the question of the ottoman name of the village of Ovidiopol

Dianova Natalia

The history of the development of the Odessa temple Kazan Icon of the Mother of God.

Poltorak Volodymyr

Conversion to islam among emigrants from Ukraine in the middle of the XIX century:

the case of Mychaylo Czajkowski (Mehmed Sadyk-pasha) ............................................2.

Yurash Yevhenii

Statistical reports of the Odessa Trustee committee for prison as a historical source. .35

Sorokina Kseniia

Petro Sokalskyi as a repreaentative of the Imperial society of agriculture of Southern Russia (1869-1871)

Korobchuk Anna

Newspaper «Odessa herald» (1827-1894) as a historical source on the history

of the Odessa Institute of Noble Maiden

Herasymenko Viktoriia

The city mayors of Odessa in the circumstaces of the revolutionary events of 1905 .......54

Muzychko Olexsandr

Volodymyr Moshynsky in the Ukrainian Cossack movement of the XX century

Bodrug Anatoliy

Socio-cultural mission of the Canadian Ukrainian cultural and educational center

«Oseredok» (second quarter of 20th - beginning of 21st century)

COSSACKS STUDIES

Grechylo Andrii

Mykola Bytynskyi and his projects of "Cossackia"'s symbols 81

Novikova Lyudmyla

Presentations of the history of right-bank and left-bank Ukraine in modern regional and historical texts: posing the problem

Lozheshnyk Oleksandr

Black sea Cossack army between the Southern Bug and the Dniester: historiography of the issue.

\section{Bachynska Olena}

\section{PUBLICATION OF HISTORICAL SOURCES}

Crimes, punishment and their execution in the villages of the Danube (Novorosiysky)

Cossack army (1828-1868)

Goncharuk Taras

Letters to odesa resident Mykhailo Komarov from St. Petersburg, Moscow, Kuban and other regions of the Russian empire outside Ukraine, as a manifestation of the consolidation of the national movement at the turn of the XIX and XX centuries 


\section{Dubna Maksym}

Activities of the "Commissioner of the Russian Orthodox Church and Religious Cults at the Council of people's commissioners of the USSR in Odessa in 1944-1965

(by materials the State archives of Odessa region).

\section{Chukhlib Taras}

\section{REFERENCES, CHRONICLE}

What history should children in 5th grade learn: to the problem of Ukrainian propedeutics

\section{Kaiuk Svitlana}

Historians and scientific-practical conference: myth or reality (on the example of scientificpractical conference "O.M. Pol' in history and city memory of Dnipro, 2020") 149

Hromovych Uliana

Black Sea Gaydamack unity: 15 years of activity 155

Contents 161 

Наукове видання

ЧОРНОМОРСЬКА МИНУВШИНА

Записки Відділу історії козацтва на півдні України

Науково-дослідного інституту козацтва

Інституту історії України НАН України

Збірка наукових праць

Випуск 15

Комп’ютерна верстка та макетування: Олена Бачинська Видано за авторською редакцією

Здано до набору 22.12.2020 р. Підписано до друку 24.12.2020 р. Формат 60x84/16. Папір осетний. Гарнітура TNR.

Друг цифровий. Ум.-друк. арк. 9,5. Наклад 300 прим.

Видавець СПД-ФО Бондаренко М.О.

(Свідоцтво про внесення суб'єкта видавничої справи до державного реєстру видавців ДК No4684 від 13.02.2014 р.)

Надруковано у ФОП Бондаренко М.О.

м. Одеса, вул. В. Арнаутська, 60. Т. +38-0482-35-79-76 info@aprel.od.ua 